This work was performed by Scientific Software Corporation. Subcontract No. X48-96245-1 with the University of California, Los Alamos Scientific Laboratory.

This report was prepared as an account of work sponsored by the United States Government. Neither the United State employees, nor any of their contractors, subcontractors, of their employees, makes any warranty. express or implied, or assumes any legal liability or responsibility for the accurac completeness, or usefulness of any information, apparatus, product, or process disclosed, or represents that its use would not infringe privately owned rights.

UNITED STATES DEPARTMENT OF ENERGY CONTRACT W-7AOS-ENG. 36 
LA-7693-MS

Informal Report

UC-66a

Issued: February 1979

\title{
Geothermal Well Log Interpretation Midterm Report
}

\author{
S. K. Sanyal* \\ L. E. Wells** \\ R. E. Bickham**
}

This report was prepared as an account of work
sponsored by the United States Government. Neither the
United States nor the United States Department of
Energy, nor any of their employees, nor any of their
contractors, subcontractors, or their ernployees, makes
any warranty, express or implied, or assumes any legal
liability or responsibility for the accuracy, completeness
or usefulness of any information, apparatus, product or
process disclosed, or represents that its use would not
infringe privately owned rights.

"Stanford University, Petroleum Research Institute, Stanford, CA 94305.

* "Scientific Software Corporation, 633 17th St., Denver, CO 80202.

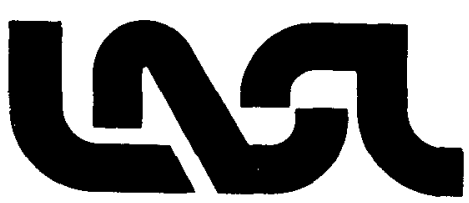




\section{DISCLAIMER}

This report was prepared as an account of work sponsored by an agency of the United States Government. Neither the United States Government nor any agency Thereof, nor any of their employees, makes any warranty, express or implied, or assumes any legal liability or responsibility for the accuracy, completeness, or usefulness of any information, apparatus, product, or process disclosed, or represents that its use would not infringe privately owned rights. Reference herein to any specific commercial product, process, or service by trade name, trademark, manufacturer, or otherwise does not necessarily constitute or imply its endorsement, recommendation, or favoring by the United States Government or any agency thereof. The views and opinions of authors expressed herein do not necessarily state or reflect those of the United States Government or any agency thereof. 
CONTENTS

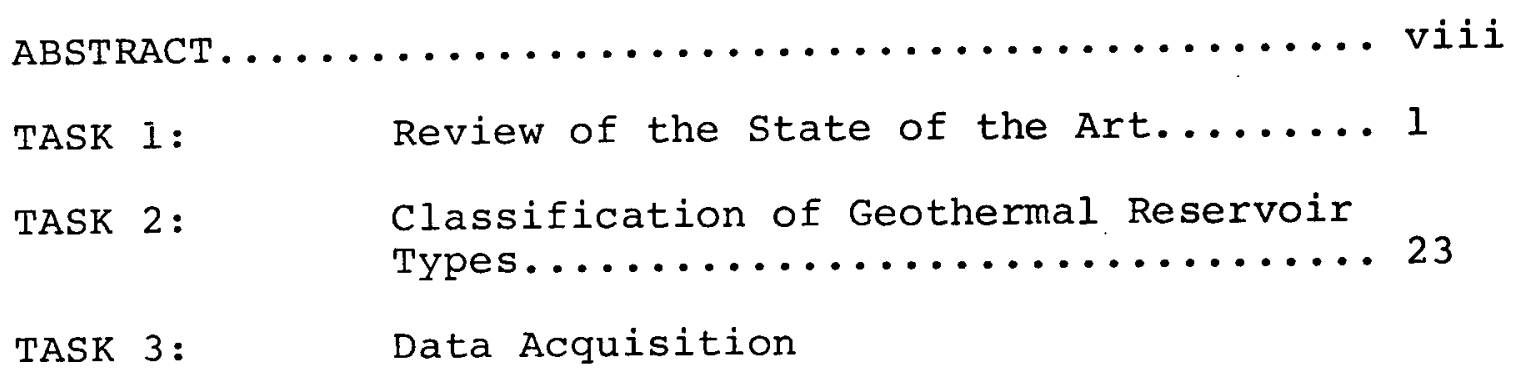

A. Well Logs................. 57

B. Literature Search............. 89

TASK 4: Problem Definition and Direction for solution..................... 99

TASK 5: Refinement of Existing Interpretation Techniques and Development of New Ones

A. Petrophysical Models........... 127

B. Matrix Response............... 137

C. Fracture Delineation............ 165

D. Temperature Transient Analysis......171

SUMMARY............................... 175

APPENDIX A. DESCRIPTION OF M-N PLOTS.............177 
LIST OF FIGURES

2.1 Temperature Distribution of Known Hot Water

Reservoirs in the U.S................... 28

2.2 Geothermal Exploration and Development in the

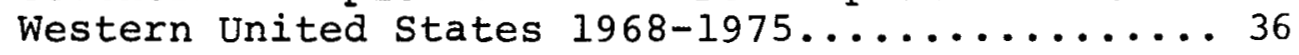

4.1 Density-Neutron Crossplot - GT\#2...........113

4.2 Sonic-Neutron Crossplot - GT\#2.............114

4.3 Density-Sonic Crossplot - GT\#2.............115

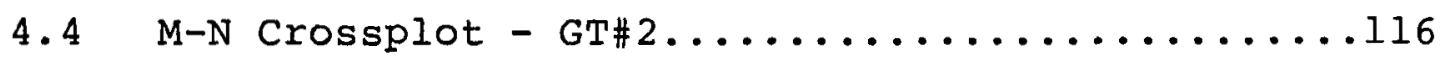

4.5 Two Mineral Model GT\#2................117

4.6 Apparent Matrix Crossplot - GT\#2............118

4.7 Apparent Matrix Z-plot - GT\#2.............119

4.8 Density-Neutron Crossplot - RRGE\#2...........120

4.9 Sonic-Neutron Crossplot - RRGE\#2............121

4.10 Density-Sonic Crossplot - RRGE\#2............122

$4.11 M-N$ Crossplot - RRGE\#2..................123

4.12 Density-Neutron Crossplot - RRGE\#2...........124

4.13 Sonic-Neutron Crossplot - RRGE\#2............125

4.14 Density-Sonic Crossplot - RRGE\#2............126

$4.15 M-N$ Crossplot - RRGE\#2.................. 127

4.16 Analog Results of 2 Mineral Model of GT-2...... *

4.17 Base Log Data of RRGE\#2................. *

4.18 Analog Results of 3 Mineral Model of RRGE\#2.... *

5.b.l Order of Crystallization of the Common Rock-

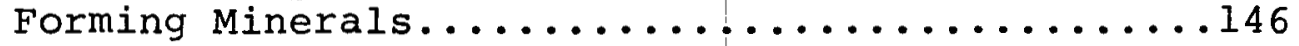

5.b.2 Classification of Metamorphic Rocks..........145

A-1 Plot and Equations for $M$ and $N \ldots \ldots \ldots \ldots \ldots 176$ *Filed Inside Back Cover 
2.1 Geothermal Reservoir Classification Schemes.... 26

2.2 Chemical Composition of Geothermal Waters..... 48

2.3 Gas Composition of Geothermal Vapors......... 51

2. 4 Relative Abundance of Chemical Composition in Geothermal Waters.................... 52

2.5 Typing of Well-known Geothermal Reservoirs.... 53

2.6 Distribution of Geothermal Reservoirs........ 54

5.b.1 Hierarchical Relationship of Minerals........ 138

5.b.2 Hierarchical Relationship of Rocks.......... 142

5.b.3 Matrix Parameters of Minerals............. 149

5.b.4 Matrix Parameters of Rocks.............. 157 


\section{GEOTHERMAL WELL LOG INTERPRETATION MIDTERM REPORT}

by

S. K. Sanyal, L. E. Wells, and R. E. Bickham

\section{ABSTRACT}

In this midterm report on geothermal well log interpretation, we have defined reservoir types according to fluid phase and temperature, lithology, geologic province, pore geometry, and salinity and fluid chemistry. Improvements are needed in lithology and porosity definition, fracture detection, and thermal evaluation for more accurate interpretation. Further efforts are directed toward improving diagnostic techniques for relating rock characteristics and log response, developing petrophysical models for geothermal systems, and developing thermal evaluation techniques.

The Geothermal Well Log Interpretation study and report has concentrated only on hydrothermal geothermal reservoirs. Other geothermal reservoirs (hot dry rock, geopressured, etc.) are not considered in this study. 


\section{DISCLAIMER}

Portions of this document may be illegible in electronic image products. Images are produced from the best available original document. 
TASK 1: REVIEW OF THE STATE OF THE ART

\section{Introduction}

In the petroleum industry, well logging is a welldeveloped discipline that has matured over five decades. Compared to this, geothermal well logging is a very new enterprise.

By and large, the current fractice has been to use the same logging equipment and log interpretation techniques for geothermal wells as is used for petroleum wells. However, this approach has proven either inadequate or ineffective in most geothermal areas. The problems here are of two types: (1) those associated with logging equipment and operation, and (2) those connected with log interpretation techriques. Temperatures encountered in geothermal wells are normally higher (greater than $175^{\circ} \mathrm{C}$ or $350^{\circ} \mathrm{F}$ ) than those in petroleum wells. In many geothermal wells, some of the standard well logs cannot be acquired because the well temperatures are higher than the maximum temperature for which the logging tools are designed.

Logging service companies are beginning to develop instrumentation and interpretation techniques for geothermal wells. For example, Schlumberger Well Services has been offering a geothermal version of their SARABAND (a Schlumberger trademark) interpretation technique for geothermal wells in the Imperial Valley of Caiffornia and the Mexicali Valley of Mexico. Dresser Atlas Corporation has recently developed a log interpretation scheme for The Geysers dry steam field based on gamma-ray, neutron, compensated density, caliper, and temperature logs. Both of these companies and other service companies are also engaged in developing new 
instrumentation for logging geothermal wells. However both instrumentation and interpretation development by the logging industry have been inadequate compared to the needs of the geothermal industry.

The Department of Energy has established a geothermal logging instrumentation development program at the Sandia Laboratories in New Mexico. The U.S. Geological survey also has a similar program of instrumentation development for geothermal logging. These programs are progressing well and there are indications that most of the hardware-related problems of geothermal well logging instrumentation will be resolved over the next few years.

\section{CURRENT PROBLEMS IN GEOTHERMAL WELL LOGGING}

This section consists of problems associated with geothermal logging. These problems (Sanyal and Meidav, 1977) are in the areas of logging objectives, operation, and interpretation.

\section{Logging Objective:}

The most important objective of petroleum well logging is the determination of porosity and hydrocarbon saturation. For this reason, the bulk of research activity in the petroleum logging industry has been confined to developing new and better tools and interpretation techniques for measuring porosity and hydrocarbon saturation. In the geothermal reservoirs there is no hydrocarbon saturation and the nature of porosity is usually substantially different from that in a petroleum reservoir. The majority of geothermal reservoirs have fracture rather than intergranular porosity while the vast majority of petroleum reservoirs have intergranular rather than the fracture porosity. The state of the art of detection and quantification of the characteristics of fractures is relatively undeveloped in the logging industry. 
It is thus apparent that even in their basic objectives the petroleum and geothermal logging industries differ; a large part of the know-how of the petroleum logging industry is not transferable to the geothermal industry.

The fundamental differences in the objectives of the two logging industries arise from the fact that petroleum reservoirs are mostly of the intergranular type occurring in relatively soft, sedimentary rocks at temperatures less than $150^{\circ} \mathrm{C}\left(300^{\circ} \mathrm{F}\right)$ and with water saturation less than 100 percent while geothermal reservoirs are usually of the fracture type occurring in hard, igneous and metamorphic rocks at temperatures higher than $150^{\circ} \mathrm{C}\left(300^{\circ} \mathrm{F}\right)$ and with 100 percent water (and rarely, steam) saturation.

Assessments of reservoir lithology and permeability are endeavors common to both industries. Here again basic differences occur. The majority of the petroleum reservoirs are in sedimentary rocks while very few commercial geothermal reservoirs except in the Imperial Valley, California, are known to occur in sedimentary rocks. The permeability in geothermal reservoirs is largely controlled by fractures and faults. The preponderance of fracturing in geothermal reservoirs is due to the hard, brittle nature of igneous and metamorphic rocks and tectonic activity in geothermal areas. Even a sedimentary-type geothermal reservoir often undergoes profuse igneous intrusion, contact metamorphism and hydrothermal alteration resulting in a brittle, fractured state.

Some of the other important objectives of geothermal well logging, such as assessment of water quality, equilibrium formation temperature, thermal and elastic properties of the formation, etc., have drawn relatively little attention in the petroleum industry, again because of the fundamental. differences in the objectives of the two industries. 
Logging Operation:

Routine well logging instrumentation in the petroleum industry is capable of working in $177^{\circ} \mathrm{C}\left(350^{\circ} \mathrm{F}\right)$ temperature. However, the majority of geothermal reservoirs are at higher temperatures. Sometimes the wellbore can be cooled down to $177^{\circ} \mathrm{C}\left(350^{\circ} \mathrm{F}\right)$ by circulation of cooled fluids before logging. But this consumes precious rig time and can be hazardous for open holes. In the case of the dry steam reservoirs at The Geysers (California), lost circulation problem is severe and wells here are usually drilled with air and cooling the borehole by fluid circulation is impractical. Many reservoirs are simply too hot to be cooled down to $177^{\circ} \mathrm{C}\left(350^{\circ} \mathrm{F}\right)$.

High-temperature (up to $260^{\circ} \mathrm{C}$ or $500^{\circ} \mathrm{F}$ ) logging cables are now available, but most logging tools are still not rated for such temperatures. Schlumberger well services has a series of high-temperature, high-pressure tools (known as HEL or Hostile Environment Logging tools) developed for deep, hot petroleum wells. Dresser Atlas Corporation has recently been successful in using their new high-temperature tools run on a special 5/16-inch single-conductor cable to log steam wells at The Geysers with temperatures of $260^{\circ} \mathrm{C}$ $\left(500^{\circ} \mathrm{F}\right.$ ) (Ehring and others, 1978). Sandia Laboratories has developed a number of high-temperature logging tools, which are currently being tested. The U.S. Geological

Survey has developed some high-temperature logging tools, of which the Borehole Televiewer has been tested successfully in many geothermal fields ( $S$. Keys, 1978). However most of these high-temperature logging tools are still not commercially available or widely tested.

The logging tools commonly used in the geothermal industry have sharply reduced lives because of the high temperature and corrosivity of geothermal fluids, even if the tool is rated for the temperature encountered. Hence 
these logging tools are not tested and calibrated often enough at these extreme conditions. Frequent breakdowns and the loss of logging tools in the well are common in geothermal operations and the hazards of a hot, open hole and the cost of rig time often lead to a rushed logging operation, which, in turn, may cause operational problems such as a stuck tool or poor log quality.

Since geothermal logging is only a few years old, very few field engineers have substantial experience in geothermal logging. Hence some problems during logging and recording may go undetected.

\section{Log Interpretation Problems:}

There are several common problems with the quality of geothermal well logs, many of which are also common in the petroleum industry. Poor quality of some geothermal logs may be due to high logging speed, improper scaling or calibration, unusual cable stretching, rugosity of the borehole, etc. Some typical examples of such problems are:

1. Discrepancy in depth between logs from the same well;

2. Lack of repeatability;

3. Improper scale;

4. Unusually high porosity because of borehole well caving;

5. Negative porosity due to wrong assumption of lithology;

6. Featureless, wandering SP curve (due to stray currents) through a thick, tight section;

7. SP baseline shift;

8. Mutually inconsistent responses of logs in a suite; 
9. Inconsistency in water resistivity calculated by various methods;

10. Inconsistent or incomplete job-specific data;

11. Discrepancy between $\log$ and core data.

Most of the above-mentioned problems are known in the petroleum industry and can usually be resolved. However, there are other types of problems associated with log quality that cannot be easily resolved. These are accurate records of times at which drilling stopped, circulation stopped, various logging tools reached the bottom, etc. and the corresponding values of measured temperature. Unless these data are given it is difficult to assess the formation temperature at the time of logging.

Another type of common problem in geothermal well log interpretation is the lack of calibration data. Well logs are calibrated and tested against known lithologies common in the petroleum reservoirs, such as sandstone and limestone. When an "unusual" rock type is encountered, the log response may appear strange. Some corrections may be necessary to such a $\log$ response.

For example, in the Los Alamos Scientific Laboratory's (LASL) Hot Dry Rock Project Well No. 2 j.n the Jemez Mountains, some zones show increase in bulk density without corresponding decrease in the sonic travel time. This can be explained by the fact that the mafic rocks encountered in these zones have higher electron densities than does the medium used to calibrate the density logging tool (West and others, 1975). In the same well a zone shows a decrease in sonic travel time corresponding to an increase in bulk density, but the apparent neutron log porosity seems to increase. This may be caused by the presence of a material with a high neutron capture cross section, possibly a mafic type of intrusion (West and others, 1975). Calibration data are not 
available to resolve this type of problem. "Unusual" responses of this type are possible from geothermal wells in unfamiliar lithology.

One of the basic problems in geothermal well log interpretation is coping with unfamiliar lithology. Standard calibration and interpretation charts for well log analysis were designed for typical petroleum reservoir lithology: sandstone, shale, limestone, dolomite, and anhydrite. In geothermal reservoirs one often encounters crystalline igneous and metamorphic rocks, vesicular volcanic rocks, glassy or crystalline volcanic rocks, volcanic ashes, and welded volcanic rock material. Lack of calibration data for such lithologies presents a problem in interpretation. Standard interpretation charts are often inadequate for geothermal reservoir lithology. For example, in the Raft River geothermal field, the points on bulk density-neutron porosity crossplots sometimes fall outside the range of standard charts.

Lack of complete log suites sometimes poses a problem in geothermal well log analysis. In the face of complex, unfamiliar and abruptly changing lithology, a three porosity logging suite is desirable and may be essential. A full log suite may not be run in all geothermal wells because of cost considerations or operational problems. This makes lithology identification and porosity evaluation difficult.

Most of the interpretation techniques and standard equations for well logs were developed for petroleum reservoirs and do not necessarily apply to geothermal reservoirs. For example, there is little validity in using such standard equations as Archie's Formula or the Humble Formula in a fractured volcanic geothermal reservoir. Some of the overlay and crossplot concepts do not apply well for geothermal 
reservoirs. Calculation of formation water resistivity from the SP or electrical resistivity logs from a geothermal well can be frustrating.

A very limited number of geothermal logs and core analysis reports are publicly available; a substantial data base of geothermal well logs is yet to be compiled.

As a result, empirical correlations (such as the Humble Formula in the petroleum industry) are yet to be developed for geothermal well log interpretation. Even for a specific reservoir, it is often difficult to develop a useful porositypermeability transform from core data. This is usually due to the presence of fractures and abrupt changes in lithology.

Another problem to be remembered in analyzing geothermal well logs is that the present state of knowledge of the effects of high-temperature, pressure, and geothermal fluid chemistry on reservoir rocks is very primitive. For this reason use of core data to normalize well log data may not be justifiable in many geothermal situations. There is a great need for research in this area.

PUBLISHED INFORMATION ON INTERPRETATION

\section{Case Histories:}

Very little has been published on the techniques and case histories of geothermal log interpretation. The purpose of this section is to review the reported examples of geothermal log interpretation. In many ways the problems of geothermal well log analysis are the problems of analyzing unfamiliar lithologies. Examples of log analysis in unfamiliar lithologies have been reported from the mining industry and only rarely from the petroleum or geothermal industries. For the purposes of this report such unfamiliar lithologies as coal 
and evaporites will not be considered; these rock types are uncommon in the U.S. geothermal reservoirs.

Khatchikian and Lesta (1973) presented a paper on log interpretation for tuffites and tuffaceous sandstone formations from southern Argentina. Tuff has been encountered in several geothermal and oil reservoirs, but very little is known about its physical properties, which vary over a wide range, depending among other factors upon the environment and conditions under which it was deposited. Log responses for water-bearing tuff and oil-bearing sandstone are very similar, especially when the formation water is relatively fresh. They constructed an interpretation model based on a lithology triangle of Light tuffite-Heavy tuffite-quartz. The model assumed that the cementation factor ( $m$ ) increased with increasing tuffite content, and that the porosities of clean tuffites could be calculated from the sonic log response, independent of tuffite content. The log responses reported by Khatchikian and Lesta (1973) can be summarized as follows.

1) Since the connate waters were generally of very low salinity, small salinity changes caused wide variations in water resistivity.

2) At low salinities, effects of clay on resistivity are more important, and a clay content evaluation becomes essential, but the natural radioactivity of some tuffites, and the occurrence of sand-streaming potential make it difficult to use the gamma-ray and SP clay indicators.

3) On the Density-Sonic cross plot, light and heavy tuffites plot above and below the sandstone line, respectively.

4) On the $M-N^{*}$ plot two types of tuffites were also recognized.

a) Light tuffites which lie above the silica point (average values are: $M=0.95$, and $\mathrm{N}=0.64$ ).

b) Heavy tuffites which lie near the dolomite point (average values are: $\mathrm{M}=0.78$ and $\mathrm{N}=0.55$ ).

*NOTE: For a brief description of $M$ and $N$, see Appendix A. 
The model was based on field data from Southern Argentina and gave good results for such fields, however, the assumptions made may not be valid for other formations of similar lithology.

A study carried out by Campbell (1968), on the log interpretation problems in Alaska had reported values of $M$ and $\mathrm{N}$ for volcanic ash similar to the ones presented for light tuffites by Khatchikian and others (]973). Sacco (1978) utilized carbon-oxygen and spectral gamma-ray logs i.n formation evaluation of the tuffite-bearing oil reservoirs in Southern Argentina. A new crossplot approach involving these two logs was successfully used for lithology determination.

In 1974, Keller and others reported results of log analysis from a I 257-m (4 123-ft) research well beneath the summit of Kilauea Volcano on the island of Hawaii. The highest recorded temperature was about $133^{\circ} \mathrm{C}\left(271^{\circ} \mathrm{F}\right)$. A wide variety of logs were run including temperature, gammagamma backscattering, neutron, induction, self-potential, natural gamma-ray, acoustic velocity, and magnetic permeability and vertical field intensity. All the penetrated formations were basalt, with generally high porosities, ranging from a few percent to nearly fifty percent. Grain densities of the encountered rocks were about $3.02 \mathrm{~g} / \mathrm{cm}^{3}$. The acoustic log indicated wave speeds for rocks with no porosity of approximately $5730 \mathrm{~m} / \mathrm{s}$. Young's modulus, as determined from a full-waveform acoustic log and a gamma-gamma density $\log$, is generally in the range from 2 to $6 \times 10^{14} \mathrm{~Pa}$. While the neutron-density crossplot was linear, the neutronsonic crossplot was not, indicating perhaps that the timeaverage formula for sonic log response was not accurate for this lithology. Based on mieasurements on 400 core plugs of the basalt from the well, the following empirical relation was obtained. 


$$
F=18 \varnothing^{-1.05}
$$

where $F$ is the formation resistivity factor and $\varnothing$ the porosity.

West and others (1975) reported qualitative analysis of a large suite of well logs run in the geothermal Test Hole No. 2 in the Fenton Hill area of New Mexico drilled by LASL as part of their Hot Dry Rock project. The lithologies encountered were volcanics, Permian red beds, shales, and limestones before reaching the target zone of crystalline rocks including granites, granodiorites, monzonites, biotite schist, and amphibolite. Equilibrium bottomhole temperature was extrapolated to $197^{\circ} \mathrm{C}\left(386^{\circ} \mathrm{F}\right)$. The various electrical logs (SP, 16-in. normal, 64-in. normal, lateral, microdevices, induction and diplog) were useful in identifying permeable zones. Except for a few zones of mafic-type rocks, which presumably have higher electron densities than does the medium generally used to calibrate the tool, the density log correlates reasonably well with the core densities. The complex lithology and the lack of data on matrix properties limited the quantitative interpretation of the density and neutron logs. Spectral gamma-ray log was very useful in distinguishing some lithologies. Full-waveform sonic log was very useful for locating fractures. Borehole seisviewer log was quite effective in delineating fractures. West and Laughlin (1976) discussed the utility of spectral gamma-ray logging in the first two wells of the LASI Hot Dry Rock project. These authors reported that spectral gamma-ray logging was useful for determining rock types, detecting fracture zones, and examining mobility of the elements $U$, $\mathrm{Th}$, and $\mathrm{K}$.

Ritch (1975) presented a fairly detailed study of a well in North Central Texas, where four separate and distinct metamorphic lithologies were penetrated over some $15750 \mathrm{ft}$.

1) Quartzite - metamorphosed sandstone

2) Phyllite - metamorphosed derivative of fine-grained sediment 
3) Calcite marble - metamorphosed limestone

4) Dolomite marble - metamorphosed dolomite Metamorphic rocks encountered had fracture permeability and very low porosity which in some instances was recorded as negative porosity. The formation contained some highly conductive minerals, making the resistivity data less reliable. The bulk densities and the interval transit times measured were higher than the grain densities and interval transit times, respectively, usually assigned to their sedimentary rock counterparts. It is believed that such high values were caused by the presence of heavier minerals such as biotite, chlorite, and muscovite. It was also found that the SP, gamma-ray and resistivity responses could be used for distinguishing phyllite from quartzite. The $\mathrm{M}-\mathrm{N}$ plot for these four lithologies resulted in a plot where these four lithologies occupied the same relative positions as would be expected for their sedimentary counterparts.

Nelson and Glenn (1975) reported a study of the influence of structural (bound) water present in the rock on the neutron log. In mineralized igneous rocks, such water can be present in the form of alteration minerals. They provide examples from two lithologies: a diabase, and an andenitelatite. Both examples are from low-porosity rocks where the bound water was found to dominate the neutron log response. They concluded that the neutron response equation must be modified to account for this effect and proposed modified crossplot relationships. For neutron-density and neutronsonic crossplots, the bound water term was incorporated in newly defined expressions for an apparent transit time and an apparent grain density.

Hobson and others (1966) described the logging program carried out in a slim hole (2-3/4 inch) drilled in an igneous rock sequence in Canada. Their qualitative correlations indicated that the most useful $\log$ in this 
sequence was the neutron log. Such features as pyroxenitedunite contacts and changes in the degree of serpentinization in dunite were clearly indicated on the log.

Keys (1976) summarized the logging problems and progress in geothermal environments. He pointed out the usefulness of in-hole gamma spectrometry, and the potential of acoustic televiewer for locating and evaluating fractures with examples from Long Valley (California) and Fenton Hill (New Mexico) geothermal areas. He presented a neutron-density crossplot from Raft River (Idaho) geothermal field.

The first published paper on the interpretation of well logs from The Geysers steam field was presented by Ehring and others (1978). The lithology in this well was meta-graywacke, greenstone, and argillite. The logging suite was gamma ray, compensated density and neutron-neutron together with temperature log. These authors reported a new log interpretation program for steam wells that calculates lithology, porosity, steam entry zones, and steam quality. These authors pointed out that more research and field experience will be necessary before their work is completed.

Besides above published case histories, several workers have made oral presentations of geothermal log interpretation results in technical meetings. Some unpublished reports on this subject exist in the files of resource companies.

\section{Laboratory Investigations:}

In the past few years, increasing numbers of petroleumbearing formations where pyrite is present have been reported. Pyritization is also seen in geothermal fields. It has been found that the effect of disseminated pyrite disturbs well log responses in an unpredictable manner. In an essentially 
experimental investigation, Clavier and others (1976) made laboratory measurements on field cores, sand packs, and chunks of pyrite.

The effect of pyrite on the porosity logs was reported to be small for Sonic and Neutron logs, but large for the Density log. The Density log was thought to be more useful in some cases for determining pyrite content than porosity. The electrical properties of pyritic rocks, for the range of frequencies used in resistivity logging, were found to be strongly dependent on the distribution of pyrite and the frequency of the measuring current. In the usual case where the concentration of pyrite was too low to provide metallic electrical continuity through the pyrite, the low-frequency resistivity measurement remained essentially undisturbed. Increasing the frequency appeared to lower the measured value of resistivity in a manner which had been related to the frequency, pyrite content, and water resistivity. The frequency effect was essentially independent of temperature and water saturation and might be corrected using an appropriate chart. When electrical continuity existed through the pyrite phase, the measured resistivity decreased dramatically at any frequency and could not be used for saturation computation. Recommendations concerning the logging program were given.

As part of a continuing laboratory study, Keller (1977) reported that the formation resistivity factor of volcanic rocks were consistently higher than would be indicated by Archie's formula for the same porosity. They experimented with core samples of volcanic rocks from the Snake River Plain (Idaho), Modoc Plateau (Oregon), Cascade Range (Oregon), Central Nevada, and Columbia Plateau (Washington). This author also reported that the compressional as well as shear wave velocities appeared to be independent of porosity. 
Hence it was concluded that the acoustic velocity measurements could not be used as a guide to porosity in volcanic rocks.

Trice and Warren (1977) reported a laboratory experiment on two granodiorite samples from Fenton Hill (New Mexico) for correlation of acoustic velocity and permeability. For pressures below about one kilobar, the permeability data agreed well with a function involving the cubic power of the compressional velocity modulus. This relation was suggested from a comparison of the kozeny relation for permeability to the form of the functional dependence of elastic moduli on porosity and pore strains. The correlation suggested that in such rocks, crack strains were essentially linear with pressure and that the same network of cracks controlled both permeability and elastic properties.

Simmons and Nur (1968) observed that the velocity of compressional waves and electrical resistivity in granite in situ measured in two 3-kilometer boreholes exhibited very little variation with depth, in contrast to the variation predicted from laboratory measurements on dry samples. These authors indicated that these observations can be explained either by the absence of small open cracks in the rocks in situ or by the effects of complete saturation with water. Roegiers and Thill (1976) performed rock characterization tests both in the field and laboratory in connection with the LASL Hot DrY Rock project. They found that the density, sonic velocity, and elastic properties determined from log interpretation showed reasonably good agreement with the ones obtained under similar laboratory conditions. The minor discrepancies could be explained, according to these authors, as proposed by Simmons and Nur (1968). Significant discrepancies were encountered by Roegiers and Thill in determining porosity in the laboratory and from 
logs. They concluded that estimation of porosity from either sonic or neutron $\log$ is impractical in such basement rocks.

In the logging and petroleum engineering literature, many authors have reported both reversible and irreversible effects of temperature on rock properties. For example, refer to Weinbrandt (1972) and Aruna (1976) for permeability, Somerton (1973) for thermal properties of rocks, Sanyal and others (1972) for electrical resistivity, Timur (1976) for sonic wave velocities, and Sanyal and others (1974) for a review of temperature effects on all important petrophysical properties.

Somerton and others (1974) measured sonic velocities, bulk and matrix compressibilities and thermal conductivities on a group of outcrop sandstones and a group of siltstone cores from the Imperial Valley geothermal area in California. The measurements were carried out at temperatures as high as $200^{\circ} \mathrm{C}$ and pressures to $16000 \mathrm{psi}$. They found a decrease in sonic velocities with increase in temperature as also observed by Timur (1976). Somerton and others (1974) also found an increase in sonic velocities with increase in pressure and with liquid saturation. If this effect of temperature on sonic velocities is ignored, overestimation of porosity from sonic logs could result.

THE STATUS OF GEOTHERMAL LOG INTERPRETATION

From the foregoing discussion it is apparent that while there are many problems still plaguing geothermal logging, some log interpretation has been possible in many cases. As logging instrumentation improves, interpretation techniques should also improve. Based on the experimental results it is apparent that the interpretation techniques for the geothermal well logs must take into account the effect of temperature on rock properties and the difference between 
the petrophysical properties of geothermal reservoir rocks and the sedimentary rocks that comprise petroleum reservoirs.

The state of the art of at least qualitative interpretation of geothermal well logs can be summarized from Table 1.1 (Sanyal and Meidav, 1977). Table 1.1 summarizes the utility of the commonly available well logs for geothermal reservoirs of the nonsedimentary lithology. For sedimentary lithology, utility of these logs will be similar to their utility in the petroleum industry. Table 1.1 does not include the use of multilog analysis and various computer techniques, which can have significant synergistic effect on geothermal formation evaluation. The only published paper on synergistic, computer interpretation of a suite of geothermal well logs from a dry steam field is that by Ehring and others (1978). The program has apparently been successful. However, longer field experience will be necessary before it can become standardized and widely used. For sedimentary geothermal systems such as the Imperial Valley of California and the Mexicali Valley of Mexico, a modified version of Schlumberger's SARABAND sand-shale analysis program has been successful. Schlumberger's complex lithology computer model (CORIBAND) has been applied with some success to the Raft River geothermal field in Idaho. Members of this project team have performed computer interpretation of geothermal well logs both for private clients and as a part of this project. Two examples of such interpretations are given in this report under Task 4.

Any quantitative interpretation of well logs needs two basic inputs: a pore model and the data on the log response of the matrix forming the rock. The state of the art of geothermal well logging indicates that these two aspects need improvement, which is one of the aims of this project. Tasks 5 and 6 in this report include details of these aspects. Detection (and delineation) of natural or induced fractures 
is a prime aim of most geothermal logging. The state of the art and efforts under this project in the area of fracture detection and delineation are discussed under Tasks 5 and 6 in this report.

The interpretation of temperature logs and estimation of the equilibrium (or static) temperature profile in a well bore are important aspects of geothermal well log analysis. An account of the state of the art and the proposed effort under this project in this area is presented under Tasks 5 and 6 in this report.

\section{REFERENCES}

Aruna, M., 1976. "The Effects of Temperature and Pressure on Absolute Permeability of Limestone," Ph.D. Dissertation, Stanford University, 1976.

Campbell, R. L., 1968. "Application of the Lithology Approach to Alaska Interpretation Problems," Internal Memo, Schlumberger, Ridgefield, Conn., April 1968 (Referenced in Khatchikian and Lesta, 1973).

Clavier, C., Heim, A., and Scala, C., 1976. "Effect of Pyrite on Resistivity and Other Logging Measurements," SPWLA Seventeenth Annual Logging Symposium, Denver, Colo., June 1978.

Ehring, T. W., Lusk, L. A., Grubb, J. M., Johnson, R. B., Devries, M. R., and Fert1, W. H., 1978. "Formation Evaluation Concepts for Geothermal Resources," SPWLA Nineteenth Annual Loggings Symposium, El Paso, Texas, June 1978.

Hobson, G. D., Beck, A. E., and Findlay, D. C., 1966. "Notes on Geophysical Logs and Borehole Temperature Measurements from the Muskox Drilling Project," Canadian Geological Survey Paper No. 66-13, 1966.

Keller, G. V., 1977. "Research and Physical Properties of Geothermal Reservoir Rocks," Program Report \#2, ERDA, Golden, Colo., January 1977.

Keller, G. V., Murray, J. C., and Towle, G. H., 1974. "Geophysical Logs from the Kilauea Geothermal Research Drill Hole," SPWLA Fifteenth Logging Symposium, McAllen, Texas, June 1974 . 
Keys, W. S., 1976. "Borehole Geophysics in Geothermal Wells-Problems and Progress," Proceedings of the Second Workshop in Geothermal Reservoir Engineering, stanford University, California, December 1976.

Keys, W. S., 1978. Personal Communication.

Khatchikian, A., and Lesta, P., 1973. "Log Evaluation of Tuffites and Tuffaceous Sandstone in Southern Argentina," SPWLA Fourteenth Annual Logging Symposium, Lafayette, Louisiana, June 1973.

Nelson, P. H., and Glenn, W. E., 1975. "Influence of Bound Water on the Neutron Log in Mineralized Igneous Rock," SPWLA Sixteenth Annual Logging Symposium, New Orleans, Louisiana, June 1975 .

Ritch, H. J., 1975. "An Open Hole Logging Evaluation in Metamorphic Rocks," SPWLA Sixteenth Annual Logging Symposium, New Orleans, Louisiana, June 1975.

Roegiers, H. J., and Thill, R. E., 1976. "Rock Characterization at a Geothermal Site," 17th Utah University Rock Mechanics U.S. Symposium Proceedings.

Sacco, E. L., 1978. "Carbon/Oxygen Log Applications in Shaly Sand Formations Contaminated with Tuffite Minerals," Trans., SPWLA Nineteenth Annual Logging Symposium, El Paso, Texas, June 13-16, 1978.

Sanyal, S. K., Marsden, S. S., Jr., and Ramey, H. J., Jr., 1972. "Effect of Temperature on Electrical Resistivity of Porous Media," SPWLA Thirteenth Annual Logging Symposium, Tulsa, Oklahoma, May 1972.

Sanyal, S. K., Marsden, S. S., Jr., Ramey, H. J., Jr., 1974. "Effect of Temperature on Petrophysical Properties of Reservoir Rocks," Paper \#SPE 4898 presented at the 49 th Annual Fall Meeting of the Society of Petroleum Engineers, Houston, Texas, October 1974 .

Sanyal, S. K., and Meidav, H. T., 1977. "Important Considerations in Geothermal Well Log Analysis," SPE paper No. 6535, presented at the $47 \mathrm{th}$ Annual California Regional Meeting of the SPE of AIME, Bakersfield, California, April 13-15, 1977.

Simmons, G., and Nur, A., 1968. "Granites-Relation of Properties in situ to Laboratory Measurements," Science, Vol. 162, pp. 789-791, November 15, 1968 .

Somerton, W. H., 1973. "Thermal Properties of Hydrocarbon Bearing Rocks at High Temperatures and Pressures," Final Report, American Petroleum Institute Research Project 117, January 1973. 
Somerton, W. H., El-Shaarani, A. H., and Mobarak, S. M., 1974. "High Temperature Pehavior of Rocks Associated with Geothermal Type Reservoirs," Paper No. SPE 4899, presented at the 44 th Annual California Regional Meeting of the SPE of AIME, San Francisco, Calif., April 4-5, 1974.

Timur, A., 1976. "Temperature Dependence of Compressional and Shear wave Velocities in Rocks," Trans. SPWLA Seventeenth Annual Logging Symp., Denver, Colo., June 9-12, 1976.

Trice, R., and Warren, N., 1977. "Preliminary Study on the Correlation of Acoustic Velocity and Permeability in Two Granodiorites from the LASL Fenton Hill Deep Borehole, GT-2, Near the Valles Caldera, New Mexico," Los Alamos Scientific Laboratory Report LA-6851-MS, Los Alamos, New Mexico, July 1977.

Weinbrandt, R. M., Ph.D. Dissertation, Stanford University, Stanford, California, January 1972.

West, F. G., Kintzinger, P. R., and Laughlin, A. W. , 1975. "Geophysical Logging in Los Alamos Scientific Laboratory Geothermal Test Hole No. 2, Los Alamos Scientific Laboratory Report LA-6112-MS, Los Alamos, New Mexico, November 1975.

West, F. G., and Laughlin, A. W., 1976. "Spectral Gamma Logging in Crystalline Basement Rocks," Kesearch Note, Geology, Vol. 4, pp. 617-618, October 1976. 
TABLE 1.1

UTILITY OF VARIOUS WELL LOGS IN NON-SEDIMENTARY LITHOLOGY

(From Sanyal and Meidav, 1977)

LOG TYPE

1. Self Potential

2. Electrical Resistivity

3. Acoustic Devices

4. Neutron Devices

5. Density

6. Gamma Ray

7. Drilling Log

8. Caliper

9. Dip Meter

10. Temperature
COMMENTS

Often poorly developed; Unreliable in massive igneous or metamorphic sections; Works in some fractured igneous and metamorphic sections; Usually not useful for correlation.

Mostly off scale in massive igneous and metamorphic sections; Can be helpful in locating fractures; Short spacing resistivity may be affected by the short-circuiting effect of borehole fluid; Focussed devices may be helpful for very resistive formations.

BHC sonic log works well unless there is significant hole enlargement; May be useful for correlation; Matrix velocity values may not be known; Useful for overlay and crossplot techniques; Full-wave sonic log valuable in locating fractures; Borehole televiewer valuable for locating fractures and delineating its orientation; Frac finder log may be useful.

Responses from unfamiliar 1ithology may be difficult to assess; May be useful for correlation.

Useful in estimating porosity and Iithology; Caving may be a problem; Log response from unfamiliar lithology difficult to assess; Useful for correlation.

Useful for correlation; Spectral gamma ray useful for lithology identification.

Drilling rate log useful for locating fracture zones and changes in 1ithology; Drill cuttings log useful for lithology identification; Useful for correlation.

Useful in resolving many log quality problems; 6-arm caliper can be used in determining dip of fracture-zone washout; Use in judging hole condition.

Not always useful because of lack of laminated structure; Dip of fractures may be unreliable.

Useful for assessing temperature gradient, and other standard uses of temperature log. 
NOTES 
Introduction and Rationale

This task calls for definition of geothermal reservoir types relevant to well log analysis. In other words, out of this task should emerge one or more classification schemes for geothermal reservoirs from the viewpoint of well log analysis; the hope being that the vast number of known geothermal reservoirs can be grouped into a small number of reservoir classes each with its distinct set of log responses and typical log analysis problems. The first step in developing such classification schemes is to examine the important reservoir characteristics having bearing on log response.

The following reservoir and fluid properties usually determine the log response of a reservoir.

\author{
1. Lithology \\ 2. Fluid Phase \\ 3. Fluid Chemistry \\ 4. Reservoir Temperature \\ 5. Pore Geometry \\ 6. Certain Overall Geological Factors
}

Lithology is perhaps the most important reservoir property so far as log response is considered, for rock matrix occupies the major fraction of the bulk volume of a reservoir. Fluid phase is important because viater and steam have different $\log$ responses as do oil and gas in petroleum reservoirs. Moreover, as will be pointed out in the next section, there are certain special problems in logging of dry steam reservoirs as compared to hot water reservoirs. 
Except for hot, dry rock systems, geothermal reservoirs are entirely saturated with water (in liquid or vapor phase). However, the chemistry of geothermal waters varies extensively depending on the nature and quantity of dissolved solids and gases, far more so than for oilfield waters. The amount of total dissolved solids (TDS), or its "equivalent sodium chloride concentration" is usually an adequate description of the chemical nature of oilfield waters. In geothermal systems, TDS alone is insufficient to describe fluid chemistry because sodium chloride is not necessarily the predominant constituent.

Reservoir temperature affects geothermal well logging in two respects: geothermal well temperature often exceeds the tolerance of many of the standard logging tools, and temperature affects most rock and fluid properties. The nature and geometry of the pore spaces have a strong influence on the sonic and resistivity log responses from a formation, for the pore spaces control the path of the sonic waves and electric current through the formation. Detection of fractures in an otherwise massive lithologic section is often the main purpose of well logging in the geothermal industry. Pore geometry is thus an important property.

Besides the rock and fluid properties mentioned above, there are certain overall geological factors that affect log response. Each geological province has an assemblage of rock and fluid properties that gives rise to a set of log responses characteristic of that province. In the petroleum industry, for example, one speaks of the Gulf coast, the Rocky Mountain area, California, the North Sea, etc., as regards typical log analysis problems. Similarly in the geothermal industry, regional (in the geological context) differences in $\log$ analysis approaches are likely to emerge in the future. 
SCHEMES FOR CLASSIFICATION OF GEOTHERMAL RESERVOIRS

From above discussions, it is apparent that as regards well log analysis, one can classify geothermal reservoirs according to any of the reservoir and fluid properties listed in the previous section. In this section, these various classification schemes will be examined in detail. Table 2.1 is a list of such classification schemes and reservoir types under each scheme.

\section{CLASSIFICATION ACCORDING TO FLUID TYPE AND TEMPERATURE}

A geothermal reservoir may be saturated with water or steam. In some cases, a primary steam cap may exist above a hot water zone. Development of a secondary steam cap or steam saturation around well bores in a hot water reservoir is possible, if during reservoir depletion the fluid pressure falls below the vapor pressure of water at the prevailing reservoir temperature. Development of steam saturation has been observed in the Wairakei hot water reservoir in New zealand. In the geothermal industry, the commodity sought after is "heat"; as such a geothermal "reservoir" need not contain any fluid so long as it contains sufficient heat and has an acceptable temperature level. One such "hot dry rock" system in the Jemez Mountains of New Mexico is being developed as a prototype by the Los Alamos Scientific Laboratory.

The temperature in a hot water reservoir may range anywhere from ambient to near the critical temperature of water, $360^{\circ} \mathrm{C}\left(680^{\circ} \mathrm{F}\right)$. The Niland (or Salton Sea) geothermal reservoir in Imperial County, California, has a reservoir temperature near the critical temperature of water. Geothermal reservoirs under development in the United States for electric power production are all at temperatures above 
TABLE 2.1

GEOTHERMAL RESERVOIR CLASSIFICATION SCHEMES

I. According to Fluid Phase \& Temperature:
A. Steam
B. High-Temperature Water: $>204^{\circ} \mathrm{C}\left(400^{\circ} \mathrm{F}\right)$
C. Moderate-Temperature Water: $149-204^{\circ} \mathrm{C}\left(300-400^{\circ} \mathrm{F}\right)$
D. Low-Temperature Water: $<149^{\circ} \mathrm{C}\left(300^{\circ} \mathrm{F}\right)$
E. Dry

II. According to Lithologic Type:

A. Sedimentary

B. Metamorphic

C. Igneous (crystalline \& glassy)

D. Volcanic Ash and associated sediments, tuff

E. Breccia

F. Hydrothermally Altered

III. According to the Geologic Province:

A. Basin \& Range

a. Wasatch Front

b. Central

c. Western Margin

B. Northwest Volcanic

a. Snake River

b. Cascade Range

c. Other

C. Salton Trough

D. Northern California Coast Range

E. Rio Grande Rift \& Colorado Plateau Borderland

F. Hawaii

G. Alaska

IV. According to Pore Geometry:

A. Sedimentary Intergranular Porosity

B. Fracture

C. Vesicular or vuggy porosity

V. According to Salinity and Fluid Chemistry:

A. Low salinity: <5 $000 \mathrm{ppm}$

B. Moderate salinity: $5000-35000 \mathrm{ppm}$

C. High salinity: $35000-100000 \mathrm{ppm}$

D. Hyper saline: > $100000 \mathrm{ppm}$

E. Dry 
$149^{\circ} \mathrm{C}\left(300^{\circ} \mathrm{F}\right)$, which is considered the lowest economic temperature limit for commercial geothermal power generation under current technology. However, reservoirs with water temperatures well below $93^{\circ} \mathrm{C}\left(200^{\circ} \mathrm{F}\right)$ are being considered for development for nonelectrical uses. The higher the temperature of a geothermal water, the higher is the thermodynamic efficiency of energy conversion and the better is the associated economics. Thus it is logical to classify geothermal reservoirs not only according to the fluid type (steam, water, dry) but also according to the fluid temperature.

For the purpose of this study, hot water geothermal reservoirs have been tentatively classified as being of a high: greater than $204^{\circ} \mathrm{C}\left(400^{\circ} \mathrm{F}\right)$, intermediate: between $149^{\circ} \mathrm{C}\left(300^{\circ} \mathrm{F}\right)$ to $204^{\circ} \mathrm{C}\left(400^{\circ} \mathrm{F}\right)$, or low: less than $149^{\circ} \mathrm{C}$ $\left(300^{\circ} \mathrm{F}\right)$ temperature class.

Figure 2.1 presents the temperature distribution of the known hot water reservoirs in the U.S., derived from the data reported in the Circular 726 of the U.S. Geological Survey (1975). Figure 2.1.a shows the number of known "hydrothermal convection systems" in each of a number of temperature classes starting from $93^{\circ} \mathrm{C}\left(200^{\circ} \mathrm{F}\right)$. It is obvious from the figure that higher temperature reservoirs are less frequent. Of the 297 hot water reservoirs listed in the Circular 726 of the U.S.G.S., 188 belong to lowtemperature class, 92 to intermediate, and 17 to high. Figure 2.1.b shows the estimated total heat contained in the known hot water reservoirs under various temperature classes. It appears that both the low-and high-temperature classes have much more heat content than the intermediate class. However, the low-temperature class being unsuitable for electrical power production is economically less attractive. The high-temperature class is the most profitable of the three, but also is less frequent in occurrence. 


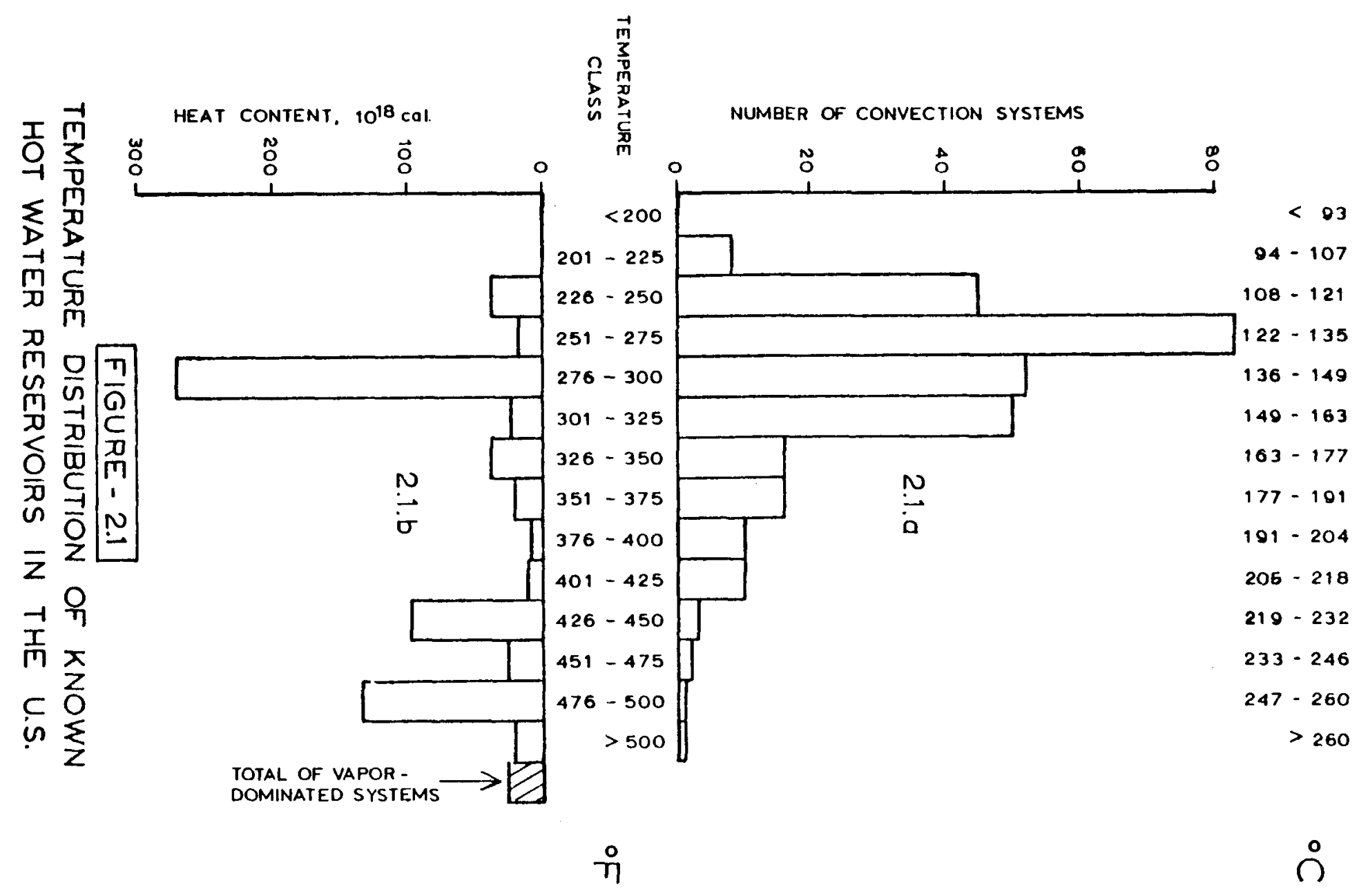


Dry steam reservoirs are rare, there being only five proven dry steam reservoirs in the world: The Geysers in California, Lardarello and Monte Amiata in Italy, and Matsukawa and onikobe in Japan. All of these are under production. As of 1976, these five reservoirs were responsible for $965 \mathrm{MW}$ out of a total worldwide geothermal power production of $1500 \mathrm{MW}$-- a share of 65 percent. While rare in occurrence, the dry steam reservoirs are prolific sources of power. Only two other possible such fields have been identified in the U.S. so far: one in the Mt. Lassen National Park, California and the other in the Yellowstone National Park, Wyoming. All the known dry steam reservoirs exhibit almost the same steam temperature and pressure in the reservoir -- around $240^{\circ} \mathrm{C}\left(464^{\circ} \mathrm{F}\right)$ and $3.4 \mathrm{MPa}(500 \mathrm{psi})$. This temperature and pressure condition corresponds to the maximum enthalpy condition for steam in contact with water. These conditions cause unusual problems in logging dry steam wells.

Out of over a hundred steam wells arilled in The Geysers, only a few have been logged because most attempts to log such wells have encountered serious problems of tool and cable malfunction due to high temperature. In The Geysers, production takes place between the depths of 180 and 2740 meters (600 to 9000 feet). Below about 300 meters (1 000 feet), the hydrostatic pressure in the wellbore exceeds the reservoir pressure. At the maximum production depth, the hydrostatic pressure reaches $26.5 \mathrm{MPa}$ (3 $800 \mathrm{psi}$ ), which is an order of magnitude higher than the reservoir pressure of 3. $4 \mathrm{MPa}$ (500 psi). Thus the steam reservoirs are underpressured, creating uncontrollable lost circulation problems if drilled with mud. The current practice at The Geysers is to drill with water or mud to the bottom of the waterbearing strata, case the well and continue drilling with air down to the steam reservoir. Sonic, dc resistivity and self-potential logs are not run in steam wells because the well is filled with air or dry steam instead of a liquid. 
Besides, the resistivity of the steam-saturated formation is too high to allow any meaningful interpretation of an electrical resistivity log. The current practice for very hot water wells is to cool the hole by circulation of a cold fluid for a period of time before logging. This is not possible for the steam wells at The Geysers because of the abnormally low reservoir pressure. Natural gamma, neutron, and density logs have been run successfully in some steam wells.

To date, no written regulations exist for radioactive source abandonment for geothermal wells in the state of California. The use of radioactive materials in California (except for uranium and plutonium) is governed by the state Department of Health, Division of Industrial Safety, Radiological Health section. This undoubtedly is a deterrent to running complete suites of well logs.

The whole gamut of standard well logs can be run in a hot water well of the low-temperature class. Such logs can be run in hot water wells of the intermediate-temperature class if the well can be cooled down by circulation to below $177^{\circ} \mathrm{C}\left(370^{\circ} \mathrm{F}\right)$, which is the current practical limit of effective operation for most logging devices. It may be impractical to cool down many of the high-temperature class wells sufficiently for logging with the standard tools. Sandia Laboratories, as well as some logging service companies, have developed high-temperature logging tools and cables which can withstand temperatures of up to $260^{\circ} \mathrm{C}$ $\left(500^{\circ} \mathrm{F}\right)$. Such devices are being tested and refined. Even when these devices become commonplace, some of the hazards of logging a hot well may still persist.

Suites of temperature, dual induction with a shallow focussed device (or less commonly, induction log alone), neutron and density with associated S.P., gamma-ray and 
caliper logs have been run in many hot water wells. Dip meter, acoustic and production logs have been run in some of the cooler wells.

Hot dry rock systems do not have any significant porosity and permeability before being fractured artificially. Hence, electrical logs have limited utility for quantitative analysis before fracturing. However, these logs, including single-point resistivity surveys, when run before and after artificial fracturing may delineate the intervals of successful stimulation. Other logs such as gamma-ray, spectral gamma ray, neutron, density and acoustic logs can be used to identify lithology and estimate mechanical properties of the formation, such as fracture pressure gradient. After artificial fracturing, several logs can be used to detect and evaluate the fractures. Full wave train sonic log, borehole televiewer, and possibly SP (may indicate streaming potential in fracture zones) and resistivity (lower resistivity in fracture zones) logs may be useful for this purpose.

Another motivation for classifying reservoirs according to temperature is that temperature level can have a significant effect on many petrophysical properties of reservoir rocks [Sanyal and others (1974)]. For example, it is well known that permeability declines with temperature (Weinbrandt (1972), Casse (1974), Aruna (1976), etc.] For this reason, the practice of normalizing of geothermal well logs by use of core data taken at ambient conditions is questionable. Unfortunately, the present state of knowledge of the effects of high temperature and pressure on reservoir rocks is primitive. It can be said, however, that the higher the temperature level, the greater are such effects. 
II. CLASSIFICATION ACCORDING TO LITHOLOGIC TYPES

From the point of view of lithology, petroleum reservoirs are usually classified into two broad classes; sandshale lithology and carbonate lithology (with or without associated sand, shale, sulfates, etc.). only rarely do petroleum reservoirs exhibit other lithological components such as pyrite, lignite or coal, tuff, etc. Conventional log analysis techniques were thus developed for sedimentary rocks, particularly for sandstone, shale, limestone, dolomite, and anhydrite Iithologies. Geothermal reservoirs on the other hand, can have any lithology -- sedimentary, igneous or metamorphic. In such reservoirs, one often encounters "unfamiliar" lithologies such as crystalline igneous and metamorphic rocks, vesicular volcanic rocks, glassy or crystalline volcanic rocks, volcanic ashes, welded volcanic rock fragments, hydrothermal deposits and alteration products. Even sedimentary geothermal reservoirs often exhibit profuse igneous intrusion, contact metamorphism, and hydrothermal alteration. Unlike sedimentary basins, igneous and metamorphic provinces, particularly those which have undergone hydrothermal alteration, often display a high degree of heterogeneity. Hence, in the same geothermal reservoir (igneous or metamorphic type), lithology may be entirely different from one horizon to another or from well to well.

An unfamiliar lithology poses several problems in logging. Standard calibration of most well logs is inadequate for such lithologies. Well logs are calibrated and tested against known lithologies common in the petroleum reservoirs. When an "unusual" rock type is encountered, the log response may appear strange. Some correction may be necessary to such a log response. For most unfamiliar lithologies, such corrections cannot be estimated. For example, in the Hot Dry Rock Project of LASL, the well GT-2 shows some zones where an increase in bulk density of the massive formation 
is not a.ccompanied by a corresponding decrease in sonic travel time. (West and others, 1975). One possible explanation of this phenomenon is that the mafic rocks encountered in these zones may have higher electron densities than coes the medium lised to calibrate the density logging tool. In the same well a zone shows a decrease in sonic travel time corresponding to an increase in bulk density, but the apparent neutron log porosity increases (West and others, 1975). This has been explained as being due to the presence of a material with a high neutron capture cross section, possibly a mafic type of intrusion. Calibration data are not available to resolve this type of problem. In the same well, a zone shows an increase in bulk density and an apparent increase in neutron porosity, which has been considered to probably indicate a material with a righ capture cross section t:o neutrons and high electron density. Standard log interpretation techniques and charts are often inadequate in dealing with unfamiliar lithologies. For example, in crossplotting multiple porosity log data, points for some geothermal zones fall outside the range of the standard crossplot charts. In some vielis in the Raft River geothermal field in Idaho, bulk densities often exceed $3.0 \mathrm{~g} / \mathrm{cm}^{3}$ which is the maximum limit of density values presented in all standard charts. During logging in an unfamiliar lithology and subsequent analysis cif logs, some log quality problems may remain undetected. Matrix properties (such as bulk density, sonic travel time, matrix neutron porosity, neutron capture cross section) of igneous and metamorphic rocks are unavailable in the logging literature. Matrix properties are available for only a few of the minerals that form igneous and metamorphic rocks.

The tentative classification of geothermal reservoirs based on lithology is shown as scheme II in Table 2.1. The logging response and associated log analysis problems of sedimentary geothermal reservoirs are similar to those for 
petroleum reservoirs. Sedimentary geothermal reservoirs may be of the sand-shale sequence type (such as Heber, East Mesa and Brawley fields in Imperial Valley, California), sandshale sequence with igneous, intrusives or hydrothermal alteration (for example, Salton Sea field, Imperial Valley, California) and sand-silt-shale sequence interlayered with volcanic ash, tuff, and volcanic flow (for example, Raft River, Idaho). No major geothermal reservoir has been discovered in carbonate rocks as yet. It is anticipated that the state of the art of well log analysis will be adequate in dealing with sedimentary geothermal lithology. However, some modifications in analysis may be required to take into account contact metamorphism, hydrothermal alteration, etc., when encountered. Computer-processed sand-shale analysis logs have been successfully run in the Imperial valley reservoirs. In Raft River, Idaho, computer-processed complex lithology logs have been obtained.

For the other lithologic types, the state of the art of well log analysis is inadequate. It is hoped that as a result of this study, systematic log analysis techniques will evolve for these lithologic types. The conventional complex lithology analysis aided by cross plots, histograms and computer processing can be applied to igneous and metamorphic-type lithologies, but matrix responses of the mineral constituents are often unknown and mineral composition may vary drastically from zone to zone. Incorporation of the spectral gamma ray log with these techniques can be useful in identifying some lithologies. (West and others, 1975).

III. CLASSIFICATION ACCORDING TO THE GEOLOGIC PROVINCE

Each geological province displays its own characteristic assemblage of petrophysical properties. For this reason, generally accepted log analysis techniques have 
evolved for each major petroleum province such as the Gulf Coast, the North Sea, etc. Such tradition is already evolving in the geothermal industry. For example, the log analysis techniques and procedures for the Imperial Valley, California geological province are standardized for all practical purposes -- sand-shale analysis techniques based on induction (or dual induction -- shallow focussed device combination) and the three porosity log suite. Log analysis procedures for other geothermal provinces are still in the experimental stage. Hence, it is important to try to classify all known geothermal areas of the United states into a limited number of geological provinces, to define the characteristic logging responses from each province, and to suggest optimum log analysis procedure for each province.

Almost all commercially significant geothermal reservoirs in the United States occur west of the Rocky Mountains in areas of geologically young (Late Cenozoic) or present day tectonism or volcanism or both. Such areas are characterized by recent silicic volcanism, high heat flow, profuse faulting and strong seismicity. The vast majority of the known geothermal reservoirs lie in the seven geological provinces listed under the classification Scheme III in Table 2.1. However, as shown in Table 2.1, these provinces can be divided into distinct subprovinces. Figure 2.2 is a map showing the location of the geological provinces mentioned above. Due to the established interpretation techniques of the petroleum industry, the "geopressured" geothermal reservoirs of the northern Gulf of Mexico Basin have been excluded from this classification.

Basin and Range Province: This geological province covers the entire state of Nevada, as well as parts of Utah, Oregon, California, Idaho, and Arizona. Two major belts of geothermal resource sites stretch along the eastern and western margins of the Basin and Range province. The eastern belt 


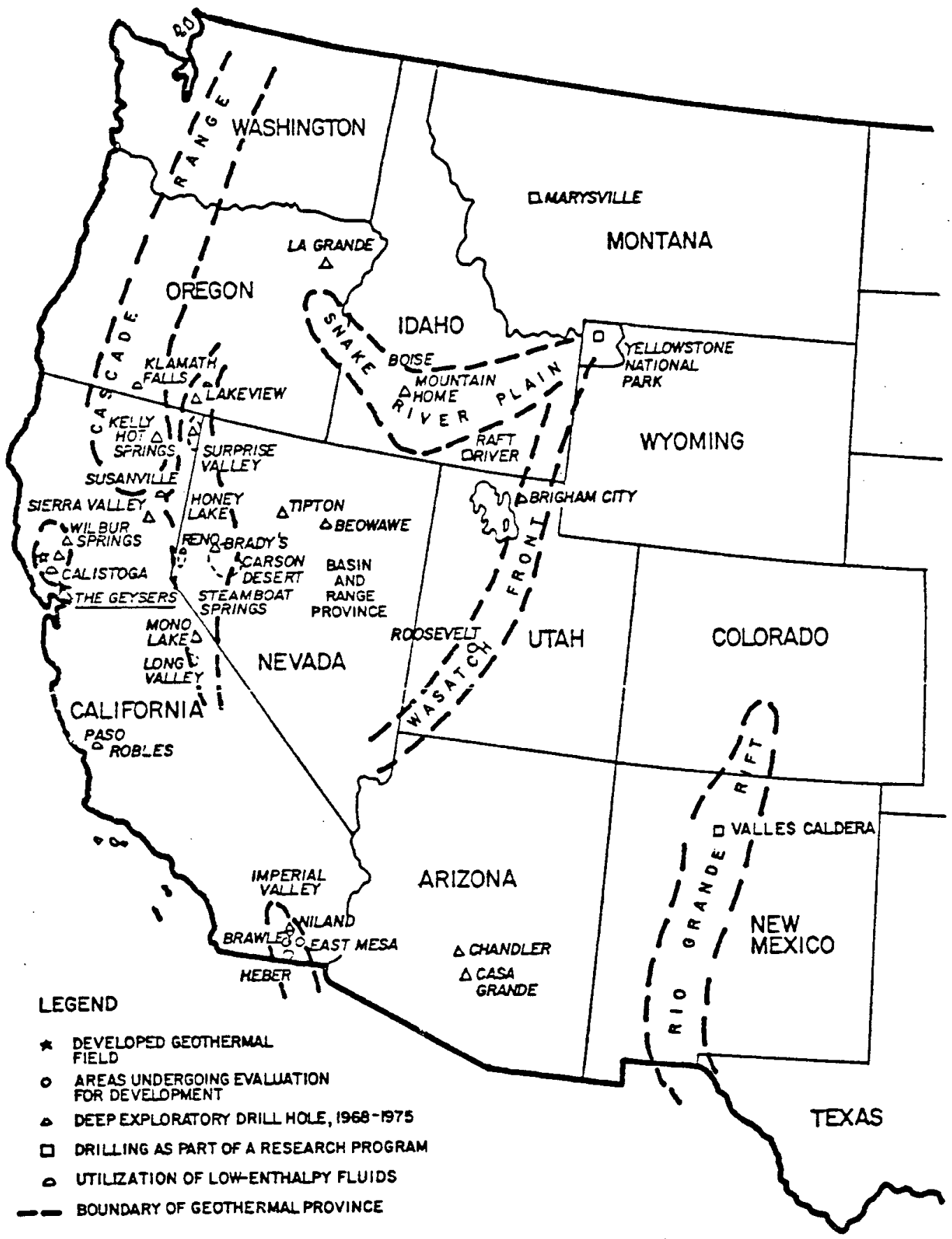

FROM: GEOTHERMAL HANDBOOK, US FISH \& WILDLIFE SERVICE, JUNE, 1976

FIGURE 22 GEOTHERMALEXPLORATION AND DEVELOPMENT IN THE WESTERN UNITED STATES 1968-1975, 
covers the wasatch Front and the area just east of it and covers parts of Idaho and Utah. The western belt passes through oregon, California, and Nevada. The central region covers Nevada and Arizona. Young silicic and basaltic volcanism and faulting are concentrated along the eastern and western belts.

The eastern belt lies just west of the Wasatch Front, which is the faulted boundary between the Basin and Range province and the Colorado Plateau-Rocky Mountains. This belt extends north-south across the entire state of Utah and into Southern Idaho, for a distance of some 560 kilometers; its width is about 100 kilometers. Geologically, the belt is similar to the western one described above; however, some geothermal reservoirs (such as Roosevelt Hot Springs) here have higher temperature. Exploratory drilling at Roosevelt Hot springs indicates a high-temperature hot-water reservoir that is of commercial quality and quantity sufficient for electric power generation (C. W. Berge, 1978, fersonal communication).

An important geothermal area in the center of the Basin and Range province is Beowawe, Nevada, where hot water at over $200^{\circ} \mathrm{C}\left(392^{\circ} \mathrm{F}\right)$ has been encountered in drill holes. other prospects have been drilled in Nevada, Oregon, and Arizona, and still others in these states and New Mexico are being explored.

The western belt extends from Lakeview, Oregon through Surprise Valley and Long Valley, to Coso, California for a distance of some 560 kilometers; it has a maximum width of 130 kilometers in the vicinity of Reno, Nevada, where it extends eastward across the Carson Desert. Geothermal reservoirs here appear to be entirely of the hot water type.

Information available on the log response and $\log$ analysis problems in this province is limited. However, it 
appears that the main log analysis problems in this geological province are coping with unfamiliar lithologies (intrusive and extrusive volcanics) and detection of fracture zones.

Northwest Province: This province covers major portions of the states of Washington, Oregon, and Idaho as well as parts of California, Nevada, Wyoming, and Montana. The Snake River Plain and the High Cascade Mountains form two distinct subprovinces.

The Snake River Plain extends over Idaho and Oregon and is covered by vast thicknesses of young basaltic lava flows. Exploration to date indicates that the reservoirs in this region are relatively large in volume but have low temperature. Most of the reservoirs in the Snake River Plain are of the low-temperature class according to our classification Scheme I. For example, Raft River, Mountain Home, and Bruneau-Grandview reservoirs of Idaho.

The High Cascades subprovince extends from British Columbia through washington and Oregon to Mount Lassen in California. The main characteristics of this region are copious cutpourings of basaltic and andesitic lavas from 2 to 10 million years old, and many recently active volcanoes, such as Hood, Shasta, Lassen, Baker, Three Sisters, and St. Helena. Occasional fumaroles are present, such as in the Lassen National Park. At Klamath Falls, Oregon, a lowtemperature geothermal reservoir has been used for space heating for several decades. Considerable exploration is taking place in this region and high enthalpy commercial geothermal reservoirs may be discovered in the future. 
In the rest of the Nortnwest volcanic province, only low-temperature geothermal reservoirs have been discovered, such as at La Grande, Oregon.

Although the $\log$ responses and $\log$ analysis problems may differ between the three subprovinces, the Northwest Volcanic province is characterized by basaltic, rhyolitic and andesitic lava flows, volcanic ash, and interlayered beds cif sediments. Complex lithology analysis techniques have been ised with some success in Raft River, Idaho. However, responses of the volcanic flows and ashes, particularly after hydrothermal alteration, are often unpredictable. Vesicles and fractures provide the main storage and flow capacity in most of these reservoirs. As such, fracture detection from wiell logs is a necessity in the area.

Salton Trough: A most important and well-known geothermal area in the United States, as far as commercial potential is concerned is the Salton Trough, which covers the Mexicali Valley of Mexico and the Imperial and Coachella Valleys of California. This area lies at the northern end of the major rift zone extending the entire length of the Gulf of California. This area is characterized by high heat flow, steep geothermal gradient, faulting, fracturing, and occasional silicic volcanism. The trough contains up to 7000 meters of Tertiary and Quaternary continental sediments.

There are at least five major geothermal reservoirs in this province. At Cerro Prieto, Mexico, a 75-megawatt geothermal power plant has been in operation since 1973 and a second 75-megawatt plant is under construction. This is a high-temperature and moderate salinity (according to our classification) reservoir. At Niland (Salton Sea), a hightemperature and hypersaline reservoir has been identified since the early $1960^{\prime} \mathrm{s}$. Extensive testing of this reservoir is in progress, but its hypersaline brine and the consequent 
corrosion and scaling problems have prevented commercial exploitation so far. Three other reservoirs of moderate temperature and moderate to high salinity occur in the Salton Trough; these are East Mesa, Heber and Brawley.

The main lithology in this frovince is deltaic sandshale sequence. Hence, standard sand-shale log analysis techniques have proven useful in this area. The sandstones can be poorly consolidated to highly cemented (or metamorphosed) and fractured. Occasionally igneous intrusives may be present, such as at Salton sea. Hydrothermal alteration is seen in places. Determination of approximate salinity of the vater from vell logs is a useful exercise in this area because of the complex distribution of saline and fresh water aquifers. The area is a prime agricultural province and yet, is a semidesert relying solely on irrigation by Colorado River water brought through canals. Hence, from the environmental as well as from a water management point of view, a knowledge of the salinity profiles in the wells is important. Well logs can be used to derive salinity profiles.

Northern California Coast Range: This province i.s relatively small in size, however, it contains the most prolific geothermal field in the world: The Geysers. This geothermal field lies in the immediate vicinity of the clear Lake and Sonoma Volcanic fields, which are geologically young and silicic in nature. The reservoirs are formed by intensely faulted and fractured graywacke. This is a subhydrostatic, dry-steam field. Low-temperature hot water reservoirs have been utilized in several locations in this province.

The logging problems of dry-steam reservoirs have been discussed before. Because of the limited logging suites available and the complex lithology, log analysis is difficult for The Geysers field. 
Rio Grande Rift and Colorado Plateau Borderland: The Rio Grande Rift is up to $160 \mathrm{~km}$ wide, and extends from the vicinity of El Paso, Texas to central colorado -- a distance of over $650 \mathrm{~km}$. The characteristics of this province are tensional faulting, basin subsidence, and repeated intrusion and extrusion of young, silicic and basaltic igneous rocks.

A number of potentially valuable prospects are present in this zone. At Valles Caldera, New Mexico, a commercial high-temperature field (fractured tuff reservoir) is being developed. Close to that field, Los Alamos Scientific Laboratory is experimenting on energy extraction from hot, dry rocks. The reservoirs are usually in fractured crystalline rocks, the main logging problems being deciphering unfamiliar lithology and fracture detection.

\section{CLASSIFICATION ACCORDING TO PORE GEOMETRY}

Well log analysis traditionally has emphasized the evaluation of the amount of a specific fluid in a given volume of porous rock. This can be accomplished by estimating the porosity and fluid saturations from well logs. However, these estimates are concerned mainly with the storage capacity of a reservoir. To be commercial, a reservoir must also have sufficient flow capacity, which is controlled by porosity as well as pore geometry. Two rocks of the same porosity can have quite different flow capacities if their pore geometries are different. For example, consider two porous media of the same porosity: one consisting of a single planar fracture and the other a bundle of parallel cylindrical pore channels (simulating intergranular porosity) across any unit cross-sectional area of the media. It can be shown that either 100 parallel cylindrical pore channels of $1-\mu \mathrm{m}$ radius or a single fracture of $0.0314-\mu \mathrm{m}$ width will give the same porosity; however, the permeability of the former will be 4.8 times the permeability of the 
latter. In geothermal systems, fracture permeability is the most frequent, followed by intergranular and vesicular for vuggy) type in frequency of occurrence. The majority of the reservoirs with crystalline igneous and metamorphic igneous rocks possess fracture permeability only. The reservoirs with sedimentary lithology usually possess intergranular permeability; fracture permeability may develop if the sediments are well consolidated, hydrothermally altered or metamorphosed. Vesicular pore geometry is seen in some volcanic flows, particularly Basaltic flows. Usually vesicular pore geometry gives rise to high permeability, an extreme case being that of pumice, which is an extremely porous volcanic rock. In general, fractured rocks display poor storage capacity but very high permeability. For example, at The Geysers, the porosity is of the order of 2 to 5 percent, while the permeabilities in producing zones can be many darcies. Intergranular pore geometry is usually associated with high porosity and moderate to low permeability. In the Imperial valley, for example, a typical reservoir has about 20 percent porosity and 200-millidarcy permeability. If the lithology is very shaly or has a high content of volcanic ash, the intergranular permeability may be very low.

The importance of classifying geothermal reservoirs according to their pore geometry lies in the fact that different pore geometries may have different log responses. For example, sonic wave propagation through rocks is generally unaffected by the presence of secondary porosity, i.e., fracture and vuggy porosity, in an intergranular-type medium. Thus, in such rocks, the porosity calculated from the sonic $\log$ is primary porosity and is lower than the porosity values obtained from density and neutron logs, which measure the total porosity. The distinction between primary and secondary porosities may be difficult for some geothermal reservoirs. For example, the vesicular pore space in a 
volcanic flow constitutes primary, rather than secondary, porosity. The sonic log may be affected by this type of porosity.

Electrical resistivity logs may be affected by the pore geometry. For example, isolated fluid-filled pore spaces (such as hydrothermal inclusions or some vesicles) cannot be detected from electrical logs. Also, the "cementation factors" of fractured rocks are different from that of intergranular-type rocks. Thus, the value of the cementation factor can be used as a means of detecting fractures from well logs. Another possible means of using electrical logs to detect fractures is to compare the formation resistivities derived from a deep induction tool (approximately $R_{t}$ ) and a shallow focussed device (approximately $R_{x o}$ ) $R_{x o}$ is usually greater than $R_{t}$ (because the mud filtrate resistivity is greater than the formation water resistivity). But in fracture zones, the apparent $R_{x o}$ may be less than $R_{t}$ ' because the shallow focussed device reads vertical resistivity and consequently will be affected more by a vertical fracture than the induction $10 \mathrm{~g}$, which reads horizontal resistivity. In massive crystalline rocks, formation resistivity is usually extremely high; except for focussed devices, measured resistivity is affected by the short-circuiting effect of the mud in the borehole. The self potential log may be used in some cases for fracture detection. Usually the SP curve appears to be featureless and wandering through massive lithologies; but in fracture zones significant streaming potential and hence an SP may be generated.

Sonic amplitude logs, which measure both compressional and shear wave amplitudes, can sometimes be used to detect fracture zones. Over fracture zones, sonic wave amplitude decreases sharply, the compressional wave being more affected by vertical or high-angle fractures and the shear waves by horizontal or low-angle fractures. Full wave train sonic 
logs may be used for visual inspection for fractures. However, these are qualitative approaches and can give only an approximate idea of the extent of fracturing. A quantitative estimate of the fracture porosity can sometimes be obtained from the difference between the porosity from density or neutron $\log$ and that from the sonic log, as discussed earlier.

It is apparent from the above discussion that fractures can possibly be detected, at least qualitatively, by several methods. The detection of vesicular or vuggy porosity may not be easy. Although it may be possible to understand the pore geometry, and estimate the amounts of primary and secondary porosities in a geothermal reservoir, the estimation of permeability is fraught with problems. Except for very limited applications of nuclear magnetic logs in the oil industry, permeabilities have always been obtained from core data or well tests. Usually, an empirical relation between permeability and porosity is established from the core data from a well, and then permeability is estimated from log-derived porosity values by applying that relation. For consolidated, intergranular formations, this approach is reasonable and has been used in the Imperial valley. If the formation is either poorly consolidated or fractured, corederived permeability may be inaccurate and often misleading. When comparing core data (which is usually taken at ambient conditions) and log data, the possible effects of elevated temperature and pressure on petrophysical properties should be considered.

V. CLASSIFICATION ACCORDING TO FLUID CHEMISTRY

The chemistry of geothermal fluids can vary extensively from field to field, from well to well in the same field, or from one zone to another in the same well. For example, the total dissolved solids (TDS) content can vary from a few hundred parts per million to over $300000 \mathrm{ppm}$. For example, 
the geothermal reservoir at Mountain Home, Idaho has a TDS of 300 to $800 \mathrm{ppm}$, which is within the TDS limits of arinking water. The salton sea geothermal reservoir has probably the most saline underground water ever discovered: a TDS of over $300000 \mathrm{ppm}$, which is close to the saturation level of the dissolved salts at the reservoir temperature.

TDS, or its "sodium chloride (NaCl) equivalent", is not an adequate description of the chemistry of a geothermal fluid, for $\mathrm{NaCl}$ is not necessarily the predominant constituent of geothermal waters. Sulfate or bicarbonate may sometimes replace chloride as the predominant anion. Moreover, depending on the geohydrological setting, a geothermal water may contain diverse types of minor constituents. Table 2.2 is a list (from Tsai and others, 1977) of the solid chemical constituents of geothermal waters and the maximum and minimum concentrations reported in the literature. Some of these constituents may have significant effects on well logs. For example, boron and lithium, common in geothermal waters, have high capture cross sections to thermal neutrons. Table 2.3 is a similar list of dissolved gases in geothermal waters. Table 2.4 from the same reference lists the major (defined as those over 10000 ppm in concentration), secondary (over $1000 \mathrm{ppm}$ ), minor (over $1 \mathrm{ppm}$ ) and trace (less than $0.01 \mathrm{ppm}$ ) constituents of geothermal waters. Detailed chemical analysis of geothermal waters is not always available, but the TDS is. Hence, TDS has been used to classify geothermal reservoirs as shown in Table 2.1 .

Electrical resistivity logs are affected by the chemistry of the fluid because the chemistry determines the resistivity of the formation water. This is important if one wants to estimate formation water salinity from well logs, where usually the dissolved solids are taken to be NaCl. Both SP and a combination of $R_{t}$ and $R_{x o}$ tools can be used to estimate "NaCl equivalent" salinities of geothermal waters. 
As formation water salinity decreases, the conductivity of the water decreases and consequently the conductivities of the clay minerals or metallic minerals become more significant relative to the overall formation conductivity. Hence, formation resistivity factors calculated from well logs are likely to be too high for such reservoirs, and consequently the calculated cementation factor is likely to be too low. For many low salinity geothermal systems, the resistivity of the mud filtrate is close or even less than that of the formation water. This causes small or positive SP deflections.

\section{FREQUENCY OF OCCURRENCE OF RESERVOIR TYPES}

It is worthwhile at this point to check the frequency of occurrence of the various reservoir types listed in Table 2.1. Most of the well-known geothermal reservoirs in the Univted States were designated a type according to each of the classification schemes proposed in Table 2.1. In Table 2.5, we have shown the typing of twenty-six such wellknown geothermal reservoirs. In Table 2.5, a type IA implies a steam reservoir, IB a high-temperature water reservoir, and so on. A type IIA/B means both type IIA and IIB lithologies are present in the reservoir. A part of Task 2 calls for typing all KGRA's (Known Geothermal Resources Areas) according to these classification schemes. Unfortunately, data are too scanty to allow reliable typing of the reservoirs other than those listed in Table 2.5. We are searching the literature to obtain as much of the needed information as possible.

Although the group of reservoirs shown in Table 2.5 is - a statistically small sample (26 reservoirs as compared to 297 identified ones), it includes most of the reservoirs under active development. Based on this sample, we can calculate the frequency of occurrences of the various reservoir types in the United States. This can be done by counting (from Table 2.5) the number of reservoirs belonging to a certain 
class and then calculating the percentage frequency of occurrence of this class compared to the other classes in the same classification scheme. For example, if there are 100 reservoirs of Type IV of which 30 are of Type IVB, then the frequency of occurrence of Type IVB reservoir is 30 percent.

Table 2.6 shows the computed frequencies of occurrence of the reservoir types under each classification scheme proposed in Table 2.1. We are attempting to prepare such a frequency table including all KGRA's. A few tentative conclusions can be drawn (about reservoirs under current development) from Table 2.6.

1. Hot water reservoirs are far more frequent than steam or dry reservoirs.

2. Besides breccia and metamorphic lithology, all other lithologies have similar frequencies of occurrence.

3. Basin \& Range province has the most numerous hydrothermal geothermal sites. This province, together with the Northwest Volcanic and Salton Trough provinces contain the bulk of the hydrothermal reservoirs.

4. Fracture type is the most common pore geometry.

5. Low-Salinity reservoirs are the most frequent.

Obviously such conclusions will be statistically significant when we include all KGRA's as in Figure 2.1. Such conclusions will help us to decide the priority to be attached to developing log analysis techniques for each reservoir. type. 
TABLE 2.2

CHEMICAE COMPOSITION OF GEOTHERMAI WATERS

(FROM TSAI et al.,1977)

Constituent

Aluminum (A1)

Ammonium $\left(\mathrm{NH}_{4}\right)$

Arsenic (As)

Barium ( $\mathrm{Ba}$ )

Boron (B)

$$
\left(\mathrm{HBO}_{2}\right)
$$

Bromide (Br)

Cadmium (Cd)

Calcium (Ca)

Carbon Dioxide $\left(\mathrm{CO}_{2}\right)$

$$
\begin{array}{ll}
\left(\mathrm{HCO}_{3}\right) & 0-10150 \\
\left(\mathrm{CO}_{3}\right) & 0-1653
\end{array}
$$$$
\left(\mathrm{HCO}_{3}+\mathrm{CO}_{3}\right)
$$$$
\left(\mathrm{CO}_{2}+\mathrm{HCO}_{3}+\mathrm{CO}_{3}\right)
$$

Cesium (Cs)

Chloride (C1)

Cobalt (Co)

Copper (Cu)

Fluoride (F)

Germanium (Ge)

Hydrogen Sulfide
Concentration in ppm

$$
0-7140
$$$$
0-1400
$$$$
0-12
$$$$
0-250
$$

$0-1200$

$13.6-4800$

$0.1-3030$

$0-1$

$0-62900$

$0-490$

$20-1000$

$15-7100$

$0.002-22$

$0-241000$

$0.014-0.018$

$0-10$

$0-35$

$0.037-0.068$

$\underset{\text { total })}{\left(\mathrm{H}_{2} \mathrm{~S},\right.} 0.2-74$ 
Chemical Composition of Geothermal Waters, cont'd.

\begin{tabular}{|c|c|}
\hline Constituent & Concentration in ppm \\
\hline Iodide (I) & $0-105$ \\
\hline Iron $(\mathrm{Fe})$ & $0-4200$ \\
\hline Lanthanum (La) & 20 \\
\hline Lead $(\mathrm{Pb})$ & $0-200$ \\
\hline Lithium (Li) & $0-300$ \\
\hline Magnesium (Mg) & $0-39200$ \\
\hline Manganese (Mn) & $0-2000$ \\
\hline Mercury (Hg) & $0-10$ \\
\hline Molybdenum (Mo) & $0.029-0.074$ \\
\hline Nickel (Ni) & $0.005-2$ \\
\hline Nitrate $\left(\mathrm{NO}_{3}\right)$ & $0-35$ \\
\hline Nitrite $\left(\mathrm{NO}_{2}\right)$ & $0-1$ \\
\hline Oxygen $\left(\mathrm{O}_{2}\right.$, dissolved $)$ & $0-10$ \\
\hline \multirow[t]{3}{*}{ Phosphate $\left(\mathrm{PO}_{4}\right)$} & $0-0.3$ \\
\hline & $0.75-2.05$ \\
\hline & $0.02-0.22$ \\
\hline Potassium (K) & $0.6-29900$ \\
\hline Rubidium (Rb) & $0-169$ \\
\hline Silica $\left(\mathrm{SiO}_{2}\right.$, total $)$ & $3-1441$ \\
\hline Silver $(\mathrm{Ag})$ & $0-2$ \\
\hline Sodium (Na) & $2-79800$ \\
\hline Strontium (Sr) & $0.133-2000$ \\
\hline Sulfate $\left(\mathrm{SO}_{4}\right)$ & $0-84000$ \\
\hline
\end{tabular}


Chemical Composition of Geothermal Waters, cont'd

Constitutent

Sulfur (S)

Total Dissolved Salts

Zinc $(\mathrm{Zn})$

Zirconium $(z r)$

\section{Concentration in $\mathrm{ppm}$}

$0-30$

The following are trace elements found at Sinclair \#4 well, Salton Sea, California

Antimony ( $\mathrm{Sb}$ ), Beryllium (Be), Bismuth (Bi), Cerium (Ce), Dysprosium (Dy), Erbium (Er), Europium (Eu), Gadolinium (Gd), Gallium (Ga), Gold ( $\mathrm{Au}$ ), Hafnium (Hf), Holmium (Ho), Indium (In), Iridium ( $\mathrm{Ir}$ ), Lutetium (Lu), Neodymium (Nd), Niobium (Nb), Osmium (Os), Palladium (Pd), Platinum (Pt), Praseodymium (Pr), Rhenium ( $R e$ ), Rhodium (Rh), Ruthenium ( $R u$ ), Samarium ( $\mathrm{Sm}$ ), Scandium (SC), Selenium (Se), Tantalum (Ta), Tellurium (Te), Terbium (Tb), Thallium (T1), Thorium (Th), Thulium (Tm), Titanium (Ti), Tungsten (W), Uranium (U), Vanadium (V), Ytterbium (Yb), Yttrium (Y). 


\section{GAS COMPOSITION OF GEOTHERMAL VAPORS}

(FROM TSAI et al., 1977)

\section{Constituent}

Ammonia $\left(\mathrm{NH}_{3}\right)$

Argon (Ar)

Arsenic (As)

Boric Acid $\left(\mathrm{H}_{3} \mathrm{BO}_{3}\right)$

Carbon Dioxide $\left(\mathrm{CO}_{2}\right)$

Carbon Monoxide (CO)

Helium (He)

Hydrocarbon $\mathrm{C}_{2}$ and greater.

Hydrogen $\left(\mathrm{H}_{2}\right)$

Hydrogen Fluoride (HF)

Hydrogen sulfide $\left(\mathrm{H}_{2} \mathrm{~S}\right)$

$$
\left(\mathrm{H}_{2}+\mathrm{H}_{2} \mathrm{~S}\right)
$$

Mercury ( $\mathrm{Hg}$ )

Methane $\left(\mathrm{CH}_{4}\right)$

Nitrogen $\left(\mathrm{N}_{2}\right)$

$$
\left(\mathrm{N}_{2}+\mathrm{Ar}\right)
$$

Oxygen $\left(\mathrm{O}_{2}\right)$

Sulfur Dioxide $\left(\mathrm{SO}_{2}\right)$

\section{Concentration in volume percent}

$$
\begin{gathered}
0-5.36 \% \\
0-6.3 \\
0.002-0.05 \\
0-0.45 \\
0-99 \\
0-3 \\
0-0.3 \\
0-18.3 \\
0-39 \\
0.00002 \\
0-42 \\
0.2-6 \\
007-40.7(\mathrm{ppb}) \\
0-99.8 \\
0-97.1 \\
0.6-96.2 \\
0-64 \\
0-31
\end{gathered}
$$


TABLE 2.4

BEIAJIV: ABUNISANCE: OF CHEMLCAI, COMPOSITION IN GEOTHERMAL WATERS

(FROM ISAI etal., 1977)

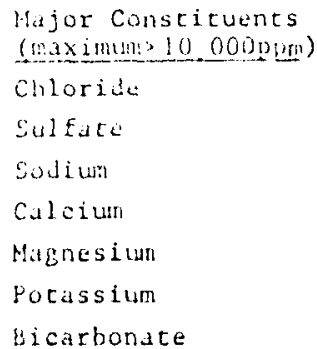

Secondary Constituents (miaximum>1 000ppm)

Aluminum

Irom

Eromide

Manganese

Strontium

Carbonate

Silica (total)

Arrmonium

Boton

Minor Constituents
(maximums lppm)
Arsenic
Barium
Cadmium
Cesium
Copper

Fluoride

Hydrogen Sulfide(total) Europlum

Iodide

Lanthanum

Lead

Lithium

Mercury

Nickel

Nitrate

Phosphate(total)

Rubidium

Silver

Zinc

2irconium
Trace Constituents

(Benerally $<0.01 \mathrm{ppm}$ )

Antimony Platinum

Beryllium Praseodymium

Bismuch

Rhenium

Cerlum

Dysprosium Ruthenium

Erbium Samarium

Gallium Tantalum

Germanlum Tellurium

Gold

Terbium

Hafnium

Thallium

Holmium

Thorium

Indlum Thullum

Iridium Titanium

L utetium Tungsten

Molybdenum Uranium

Neodymium Vanadium

Nloblum Yeterbium

Osmium Yetrium

Palladium 
TABLE 2.5

TYPING OF WELL-KNOWN GEOTHERMAL RESERVOIRS (according to Classification schemes in Table 2.1)

\begin{tabular}{|c|c|c|}
\hline RESERVOIR & LOCATION & TYPE \\
\hline Salton Sea & Imperial Co., California & $\begin{array}{l}I B, I I A / \Omega, I I I C, \\
I V A / B, V D\end{array}$ \\
\hline Brawley & Imperial Co., California & IB, IIA, IIIC, IVA, VC \\
\hline Heber & Imperial Co., California & IC, IIA, IIIC, IVA, VB \\
\hline East Mesa & Imperial Co., California & IC, IIA, IIIC, IVA, VB \\
\hline Dures & Imperial Co., California & ID, IIA, IIIC, IVA, VB \\
\hline Cerro Prieto & Baja California, Mexico & IB, IIA, IIIC, IVA, VB \\
\hline The Geysers & Sonoma Co., California & IA, IIB, IIID, IVB, VA \\
\hline Coso Hot Springs & Inyo Co., California & $\begin{array}{l}I C, I I B / C, I I I A C, I V B, \\
V B\end{array}$ \\
\hline Long Valley & Mono Co., California & $\begin{array}{l}\text { IC, IIC/D, IIIAC, IVB, } \\
V A\end{array}$ \\
\hline Surprise Valley & Modoc Co., Calisornia & $\begin{array}{l}\text { IC, IIA/C/D, IIIAC/5b, } \\
\mathrm{VA}\end{array}$ \\
\hline Clear Lake & Lake County, California & $I C, I I B / F, I I D, I V B, V F$ \\
\hline Kilauea & Hawaii & $\begin{array}{l}I B, I I C / F, I I I F, I V B / C, \\
V A\end{array}$ \\
\hline Bruneau-Grand View & Owyhee Co.. Idaho & $\begin{array}{l}\text { ID, IIA/C/D, IIIBa, } \\
\text { IVA/C, VA }\end{array}$ \\
\hline Reft River & Cassia Co., Idaho & $\begin{array}{l}\text { ID, IIA/C/D, IIIBa, } \\
\text { IVA, VA }\end{array}$ \\
\hline Mountain Home & Elmore Co., Idaro & $\begin{array}{l}I C, I I C / D, I I B C, \\
I V B / C, V A\end{array}$ \\
\hline Yellowstone & Park Co., Wyoming & $\begin{array}{l}I A / B, I I C / D / F, \text { IIIBC, } \\
I V B / C, V A\end{array}$ \\
\hline $\begin{array}{l}\text { Roosevelt Hot Springs } \\
\text { Brigham City }\end{array}$ & $\begin{array}{l}\text { Beaver Co., Utah } \\
\text { Utah }\end{array}$ & $\begin{array}{l}\text { IB, IIC, IIIA.A, IVB, V3 } \\
\text { ID }\end{array}$ \\
\hline Valles Celdera & Sancoval Co., New Mexico & IB, IIC/F, IIIE, IVB, \\
\hline Fenton H:11 & Sandoval Co., New Mexico & IE, IIC/F, IIIE, IVB, \\
\hline Chandle = & Arizona & $I C, V C$ \\
\hline Brady's Hot Springs & Iyon/Churchill Co., Nevada & $\begin{array}{l}I B, I I A / C / D / F, \text { IIIAC, } \\
I V A / B, V A\end{array}$ \\
\hline Steamboat Sp=ings & Washoe Co., Nevada & $\begin{array}{l}I C, I I C / D / F, \text { IIIAC, } \\
I V B / C \text {, VA }\end{array}$ \\
\hline $\begin{array}{l}\text { Fly Ranch } \\
\text { Rlamath Falis }\end{array}$ & $\begin{array}{l}\text { Lander/Eureka Co. , Nevada } \\
\text { Nevada } \\
\text { Oregon }\end{array}$ & $\begin{array}{l}\text { IB, IIC/D/F, IIIAb, } \\
\text { IVB, VA } \\
\text { ID } \\
\text { ID }\end{array}$ \\
\hline
\end{tabular}


TABLE-2.6

DISTRIBUTION OF GEOTHERMAL RESERVOIRS

I. ACCORDING TO FLUID PHASE \& TEMPERATURE

Type

Description

Frequency of occurrence

IA Steam $7.4 \%$

IB High-Temperature water $>204^{\circ} \mathrm{C}\left(400^{\circ} \mathrm{F}\right)$

$33.3 \%$

IC Moderate-Temperature Water $149-204^{\circ} \mathrm{C}$

$\left(300-400^{\circ} \mathrm{F}\right) 33.3 \%$

ID Low-Temperature Water $<149^{\circ} \mathrm{C} \quad\left(300^{\circ} \mathrm{F}\right)$

$22.3 \%$

IE Dry

$3.7 \%$

II. ACCORDING TO LITHOLOGIC TYPES

Type

$\underline{\text { Description }}$

IIA Sedimentary

Frequency of

IIB Metamorphic

$22.2 \%$

IIC Igneous (Crystalline \& Glassy)

$6.7 \%$

IID Volcanic Ash and associated sediments

$31.1 \%$

IIE Breccia

$20.0 \%$

IIF Hydrothermally altered

$20.0 \%$ 
TABLE-2.6 (Continued)

III. ACCORDING TO GEOLOGIC PROVINCE

Type

Description

IIIA Basin \& Range

IIIB Northwest Volcanic

IIIC Salton Trough

IIID Northern California Coast Range

IIIE Rio Grand Rift \& Colorado Plateau Borderland

IIIF Hawaii

IIIG Alaska

IV. ACCORDING TO PORE GEOMETRY

Type

IVA Sedimentary Intergranular

IVB Fracture

IVC Vesicular or Vuggy

V. ACCORDING TO SALINITY

Type

$V A$ Low Salinity $(<5000 \mathrm{ppm})$

VB Moderate Salinity (5000-35000 ppm)

VC High Salinity (35000-100000 ppm)

VD Hyper Saline (>1000000 ppm)

VE Dry
Frequency of

Occurrence

$38.5 \%$

19.2 응

$23.0 \%$

$7.7 \%$

$7.7 \%$

$3.9 \%$
Frequency of Occurrence

$31.3 \%$

$50.0 \%$

$18.7 \%$
Frequency of Operation

52.1 음

$30.4 \%$

$8.7 \%$

$4.4 \%$

$4.4 \%$ 


\section{REFERENCES}

Aruna, M., "The Effects of Temperature and Pressure on Absolute Permeability of Limestone." Ph.D. Dissertation, Stanford University, 1978.

Casse, S. J., "The Effect of Temperature and Confining Pressure on Fluid Flow Properties of Consolidated Rocks," Report \#SGP-TR-3, Stanford Geothermal Project, Stanford University, November 1974.

Sanyal, S. K., Marsden, S. S., and Ramey, H. J., Jr., "Effect of Temperature on Petrophysical Properties of Reservoir Rocks," Paper SPE4898, 49th Annual Fall Meeting of SPE of AIME, Houston, Texas, October 1974.

Shannon, D. W., Walter, R. A., and Lessor, D. L., "Brine Chemistry and Combined Heat/Mass Transfer;" Electric Power Research Institute, Research Project 653-1, Volume 1 and Volume 2, January 1978 .

Tsai, F., Sanyal, S. K., and Inprasert, S., "A Review of Chemical Composition of Geothermal Brines," 2nd Workshop on Geothermal Effluent Sampling and Analysis, USEPA, Las Vegas, Nevada, February 1977.

Weinbrandt, R. M., "The Effect of Temperature on Relative Permeability," Ph.D. Dissertation, Stanford University, May 1972 .

West, F. G., Kintzinger, P. R., and Purtymun, W. D., "Hydrologic Testing Geothermal Test Hole No. 2," Los Alamos Scientific Laboratory Report LA-6017-MS, July 1975. 
The interpretation of well logs in complex formations requires a great deal of data. After reliable techniques have been developed, less information may be needed to provide answers to some of the problems. A Criterion for Log Selection was established to select wells for initial study and model àevelopment.

\section{A. Criterion for Log Selection}

A. Logging Suites

1. Clastics

a. Resistivity and SP

b. Porosity/Lithology logs

Best: Density/Neutron/Sonic/Gamma Ray/Caliper

or Density/Neutron/Gamma Ray/Caliper

or Density/Sonic/Gamma Ray/Caliper

c. Temperature and/or Pressure data

2. Other Lithologies

a. Resistivity and SP

b. Porosity/Lithology logs

Density/Neutron/Sonic/Gamma Ray/Caliper

c. Temperature and/or Pressure cata.

B. Quality

1. Properly calibrated

2. Repeatable

3. Reasonable hole conditions (Minimum of hole washouts and borehole rugosity)

4. Overlaps of previous runs (when applicable)

C. Auxiliary Logs and Data (no priority order)

1. Sample Descriptions

2. Drilling record

3. Core and Core Analysis

4. Temperature logs 
5.. Pressure surveys

6. Production test results

7. Spectral. Gamma Ray (K, U, Th)

8. Acoustic Wave

Fields with the most complete data available for study are from

1. East Mesa (California)

2. Raft River (Idaho)

3. Fenton Hill (HDR Project, LASL, New Mexico)

The following catalog lists well logs currently available for study. 


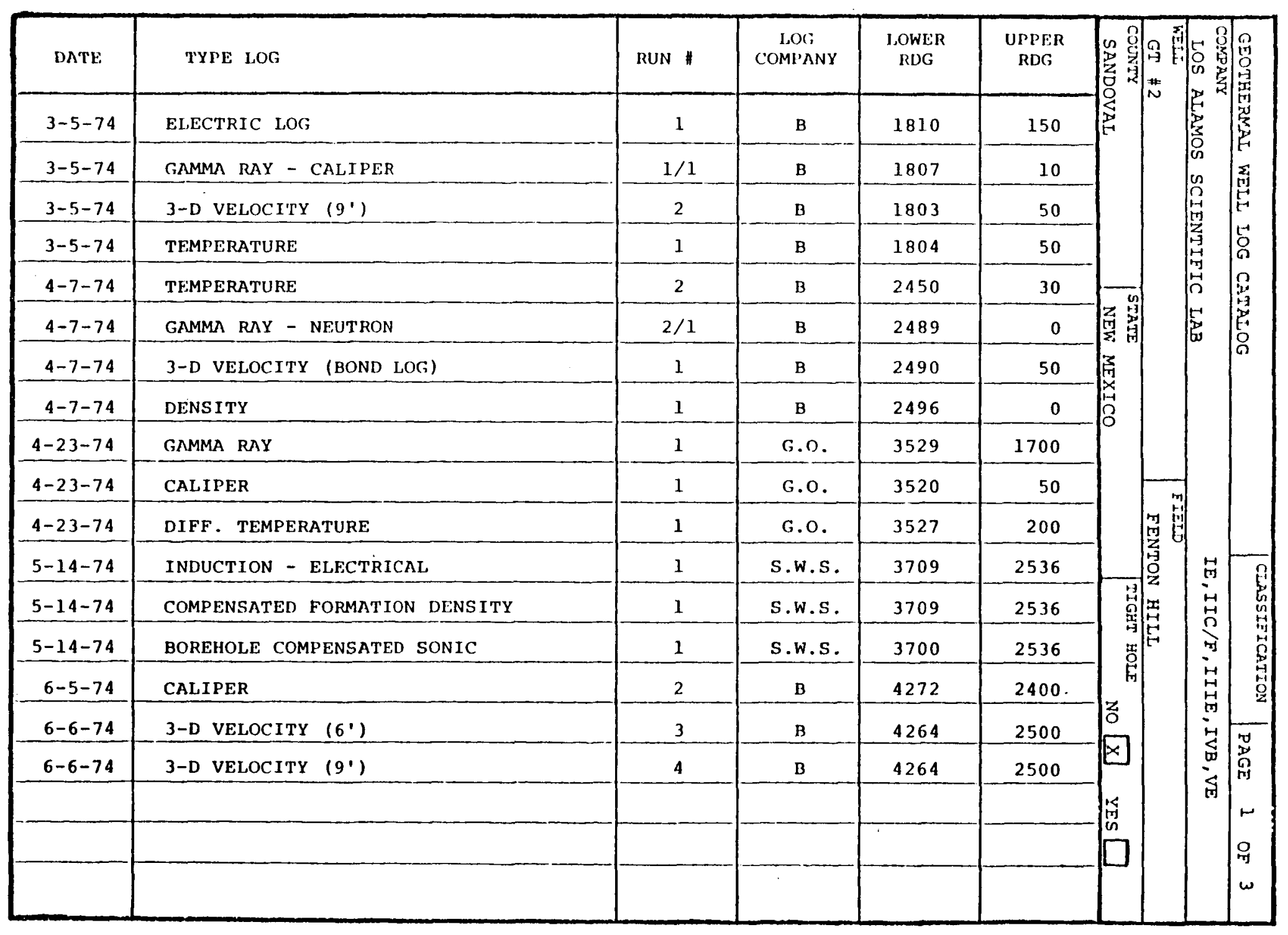




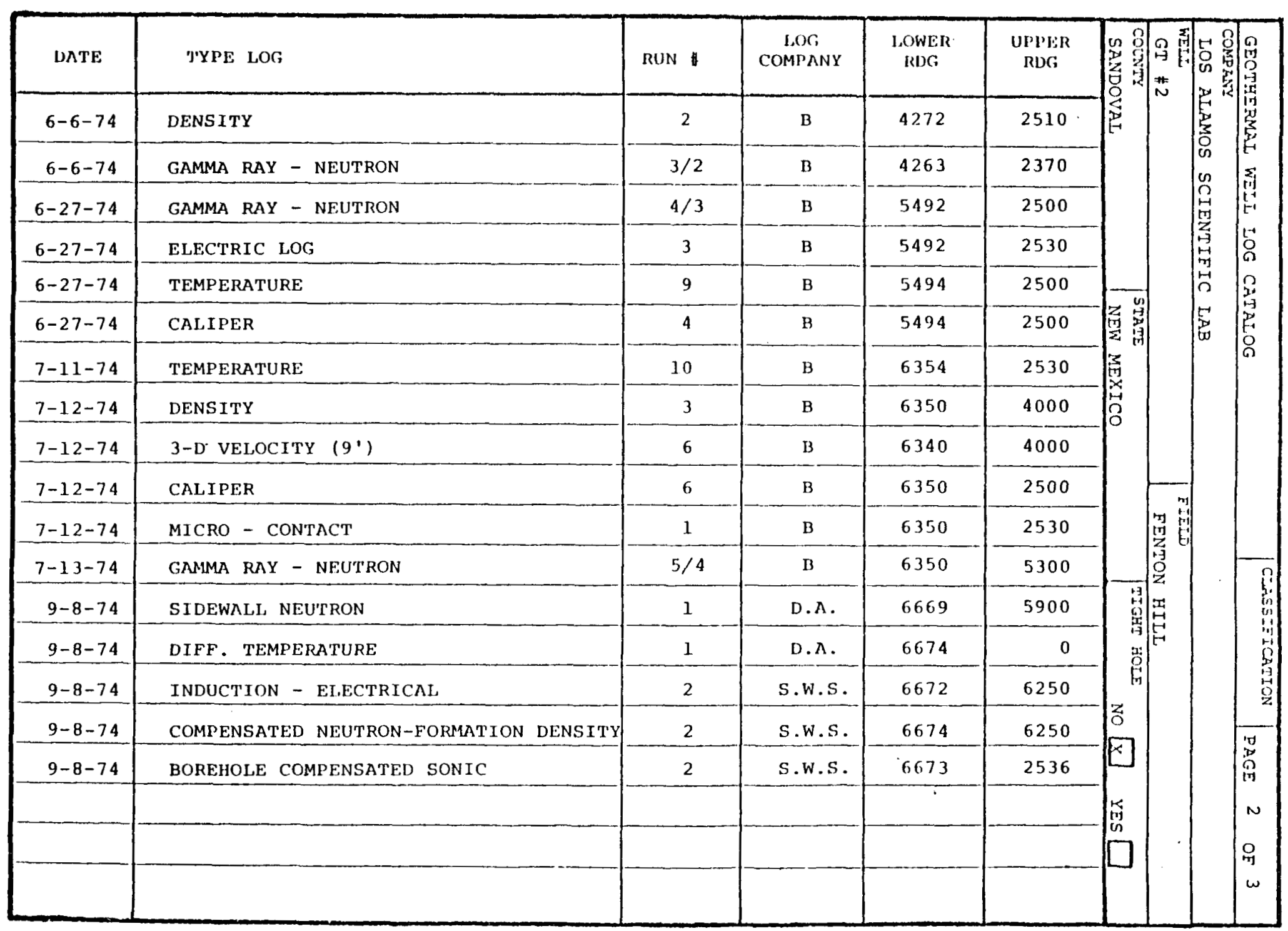




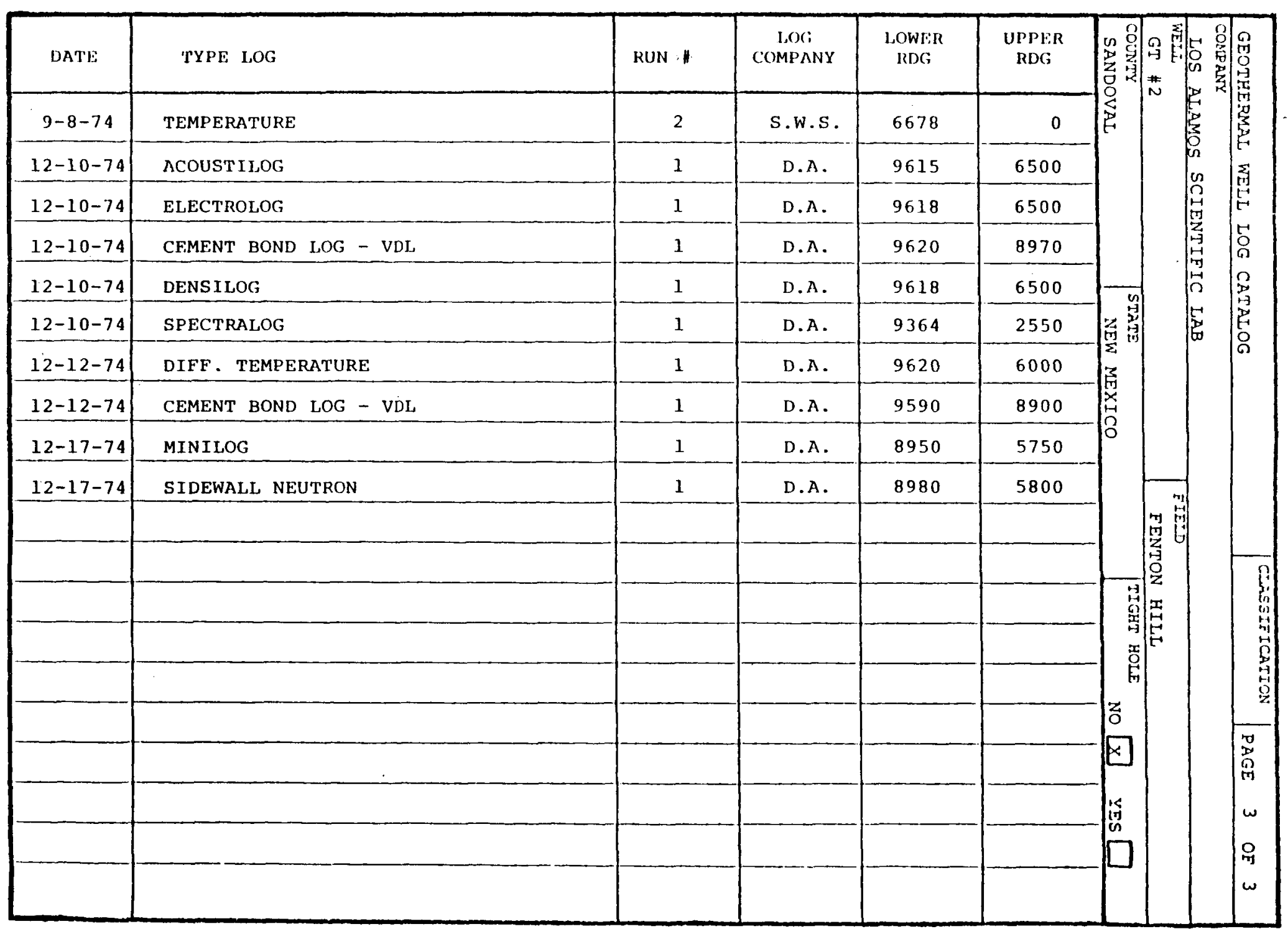




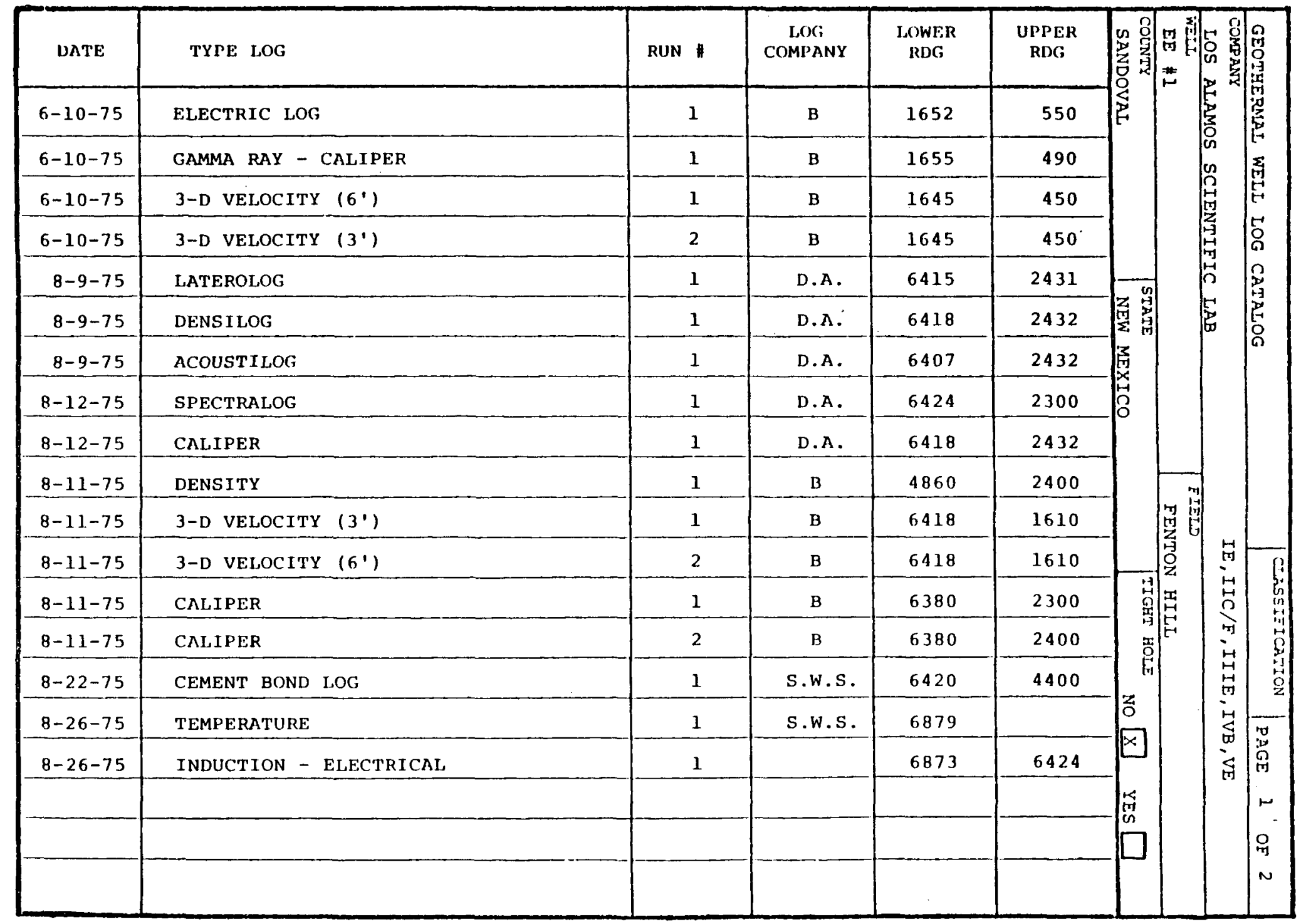




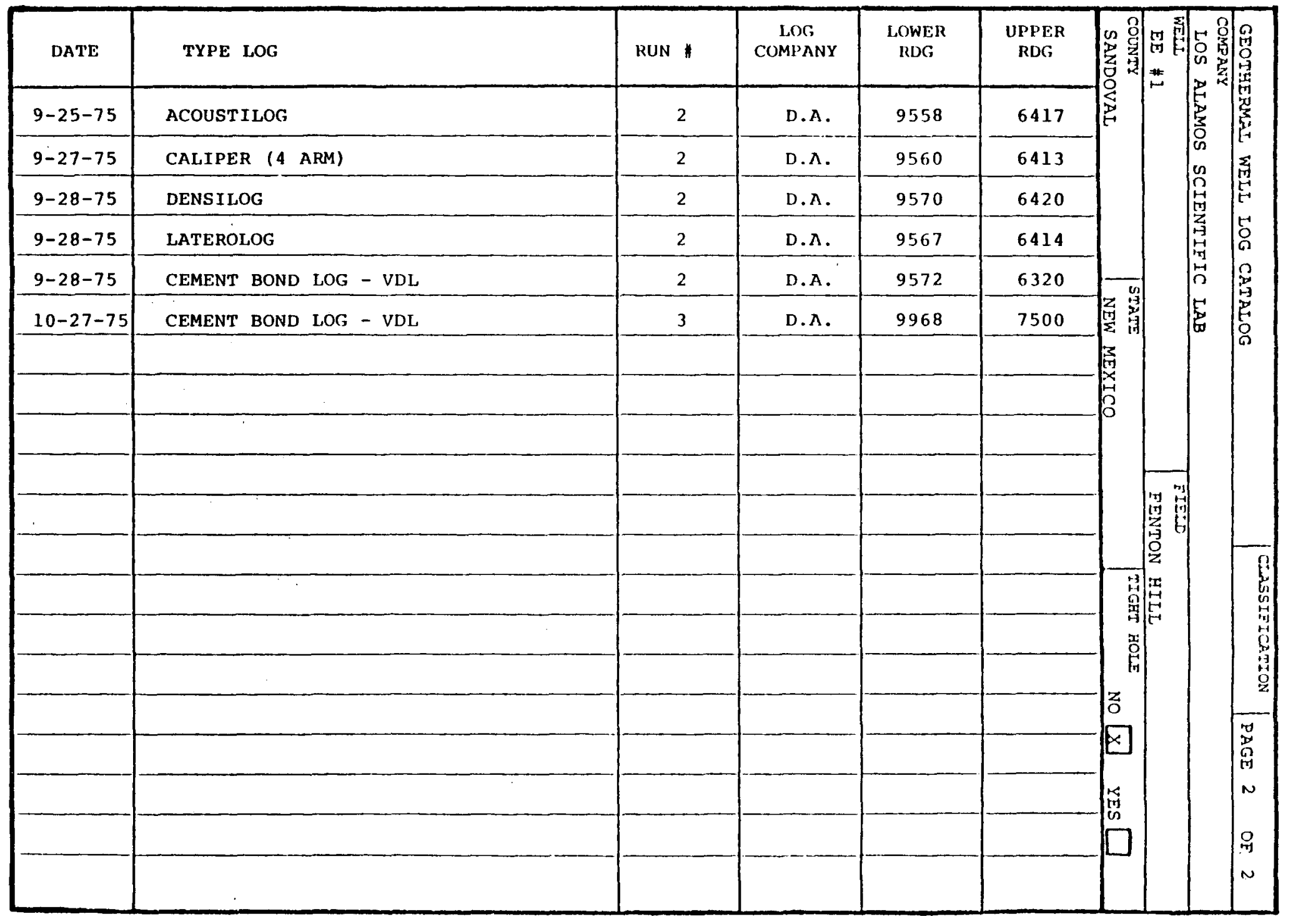




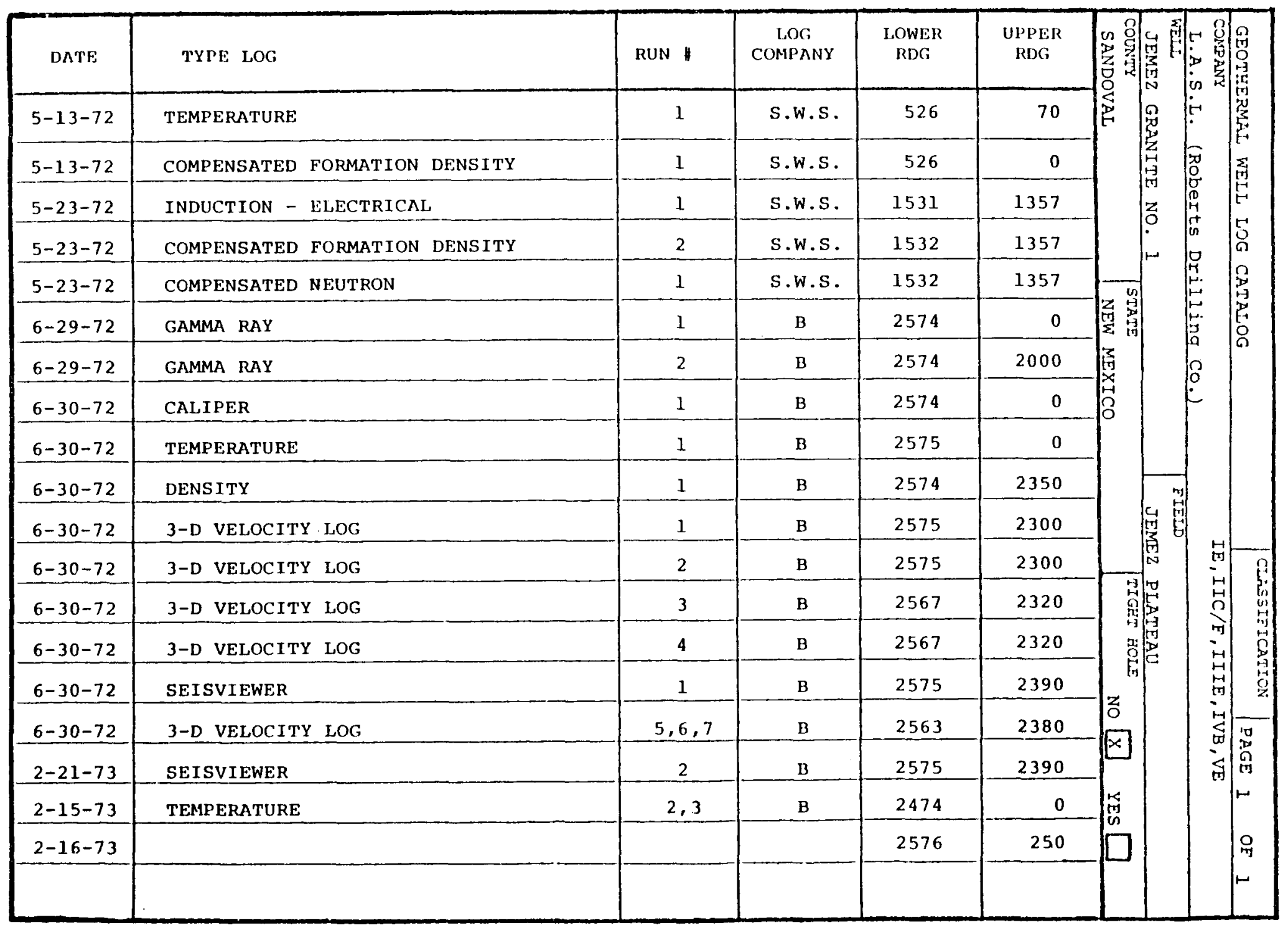




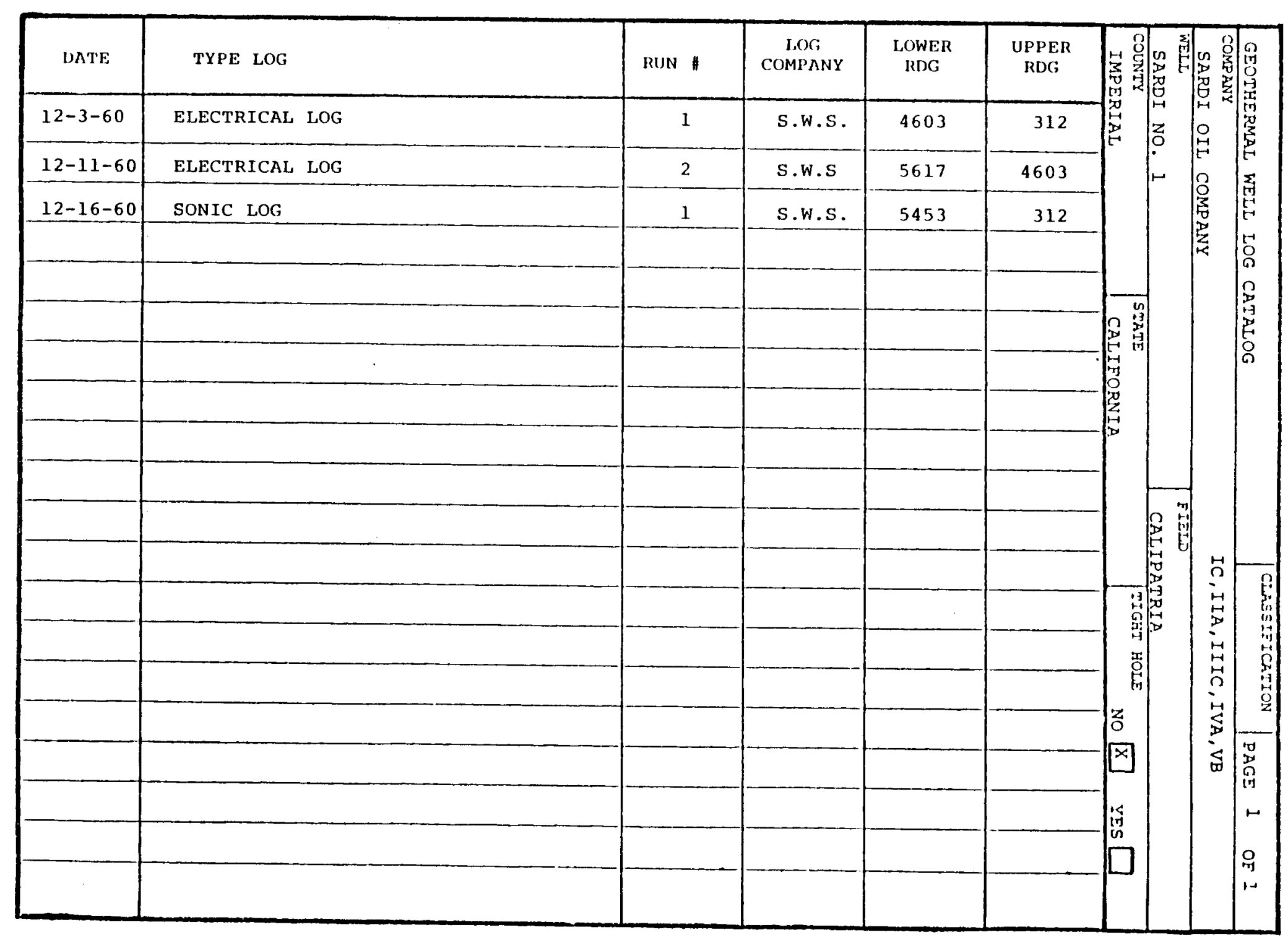




\begin{tabular}{|c|c|c|c|c|c|c|c|c|}
\hline DATE & TYPE LOG & RUN I & $\begin{array}{c}\text { LOG } \\
\text { COMPANY }\end{array}$ & $\begin{array}{c}\text { L.OWER } \\
\text { RDG }\end{array}$ & $\begin{array}{c}\text { UPPER } \\
\text { RDG }\end{array}$ & \multirow{12}{*}{\multicolumn{3}{|c|}{ 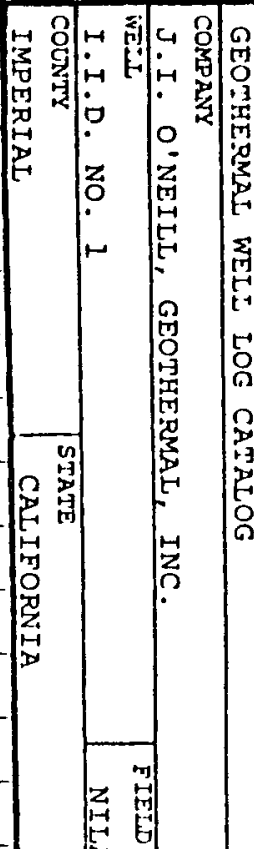 }} \\
\hline $2-18-62$ & ELECTRICAL LOG & 1 & s.w.s. & 5234 & 1624 & & & \\
\hline $2-23-62$ & TEMPERATURE & 1 & s.w.s. & 2840 & 100 & & & \\
\hline $2-18-62$ & GAMMA RAY - NEUTRON & 1 & s.w.s. & 1701 & 64 & & & \\
\hline & & & & & & & & \\
\hline & & & & & & & & \\
\hline & & & & & & & & \\
\hline & & & & & & & & \\
\hline & & & & & & & & \\
\hline & & & & & & & & \\
\hline & & & & & & & & \\
\hline & & & & & & & & \\
\hline & & & & & & & & sh \\
\hline & & & & & & 菠 & & 弐 \\
\hline & & & & & & 等 & & 鳥 \\
\hline & & & & & & 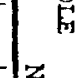 & & 范 \\
\hline & & & & & & $\mid z$ & & 5 \\
\hline & & & & & & -4 & & 出敛 \\
\hline & & & & & & 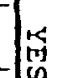 & & r \\
\hline & & & & & & $0^{n}$ & & 요 \\
\hline & & & & & & & & \\
\hline
\end{tabular}




\begin{tabular}{|c|c|c|c|c|c|c|c|c|c|}
\hline DATE & TYPE LOG & RUN & $\begin{array}{c}\text { LOG } \\
\text { COMPANY }\end{array}$ & $\begin{array}{c}\text { LOWER } \\
\text { RDG }\end{array}$ & $\begin{array}{c}\text { UPPER } \\
\text { RDG }\end{array}$ & \multirow{8}{*}{\multicolumn{4}{|c|}{ 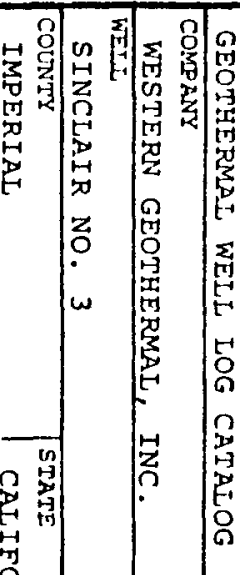 }} \\
\hline $12-1-62$ & INDUCTION - ELECTRICAL LOG & 1 & s.w.s. & 5329 & 1365 & & & & \\
\hline $12-1-62$ & SONIC LOG & 1 & s.w.s. & 5325 & 3300 & & & & \\
\hline $12-1-62$ & TEMPERATURE & 1 & s.w.s. & 5324 & 1450 & & & & \\
\hline & & & & & & & & & \\
\hline & & & & & & & & & \\
\hline & & & & & & & & & \\
\hline & & & & & & & & & \\
\hline & & & & & & 罟 & & & \\
\hline & & & & & & & & & \\
\hline & & & & & & & 9 & & \\
\hline & & & & & & & 㺼 & & \\
\hline & & & & & & & $\sqrt{18}$ & & a \\
\hline & & & & & & & 匍徏 & & $\begin{array}{l}5 \\
\vdots \\
\vdots \\
\vdots\end{array}$ \\
\hline & & & & & & & 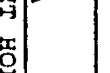 & 宫 & 照 \\
\hline & & & & & & 崩 & 需 & مิ & 诫 \\
\hline & & & & & & o & & & $\frac{{ }^{2}}{\bar{y}} \mid$ \\
\hline & & & & & & 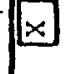 & & & 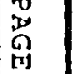 \\
\hline & & & & & & 留 & & & 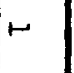 \\
\hline & & & & & & $m^{\infty}$ & & & gr \\
\hline & & & & & & & & & \\
\hline
\end{tabular}




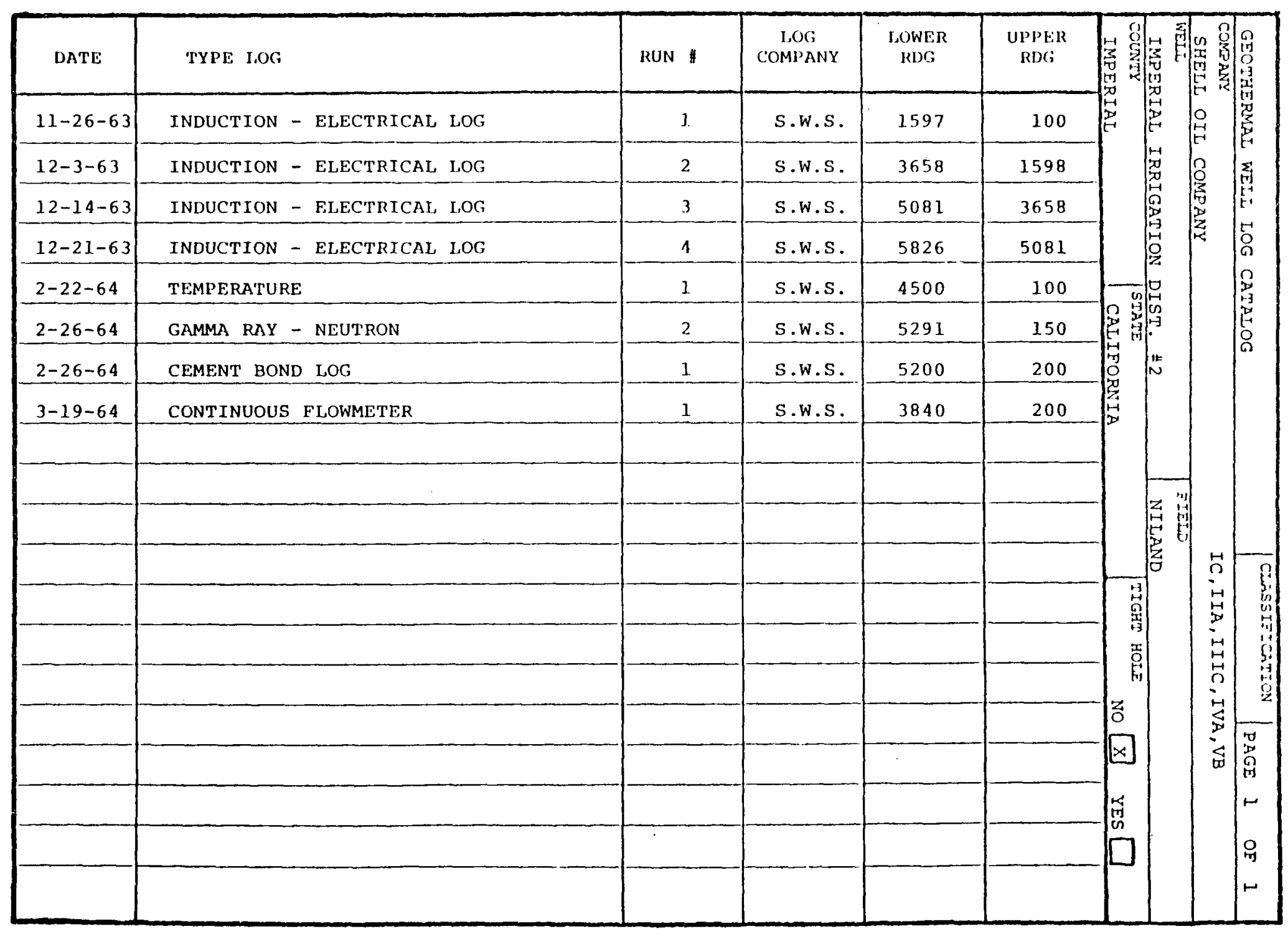




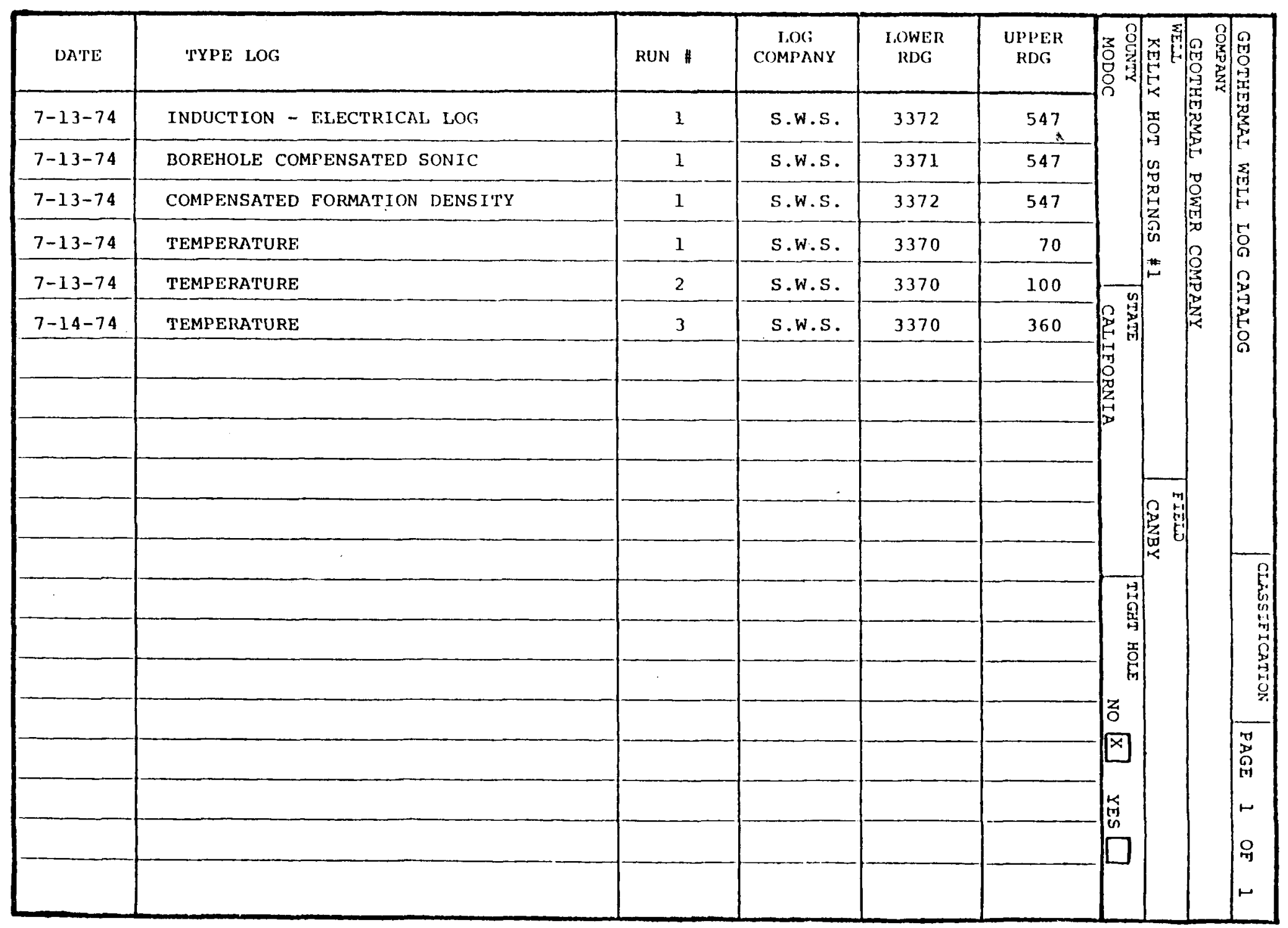




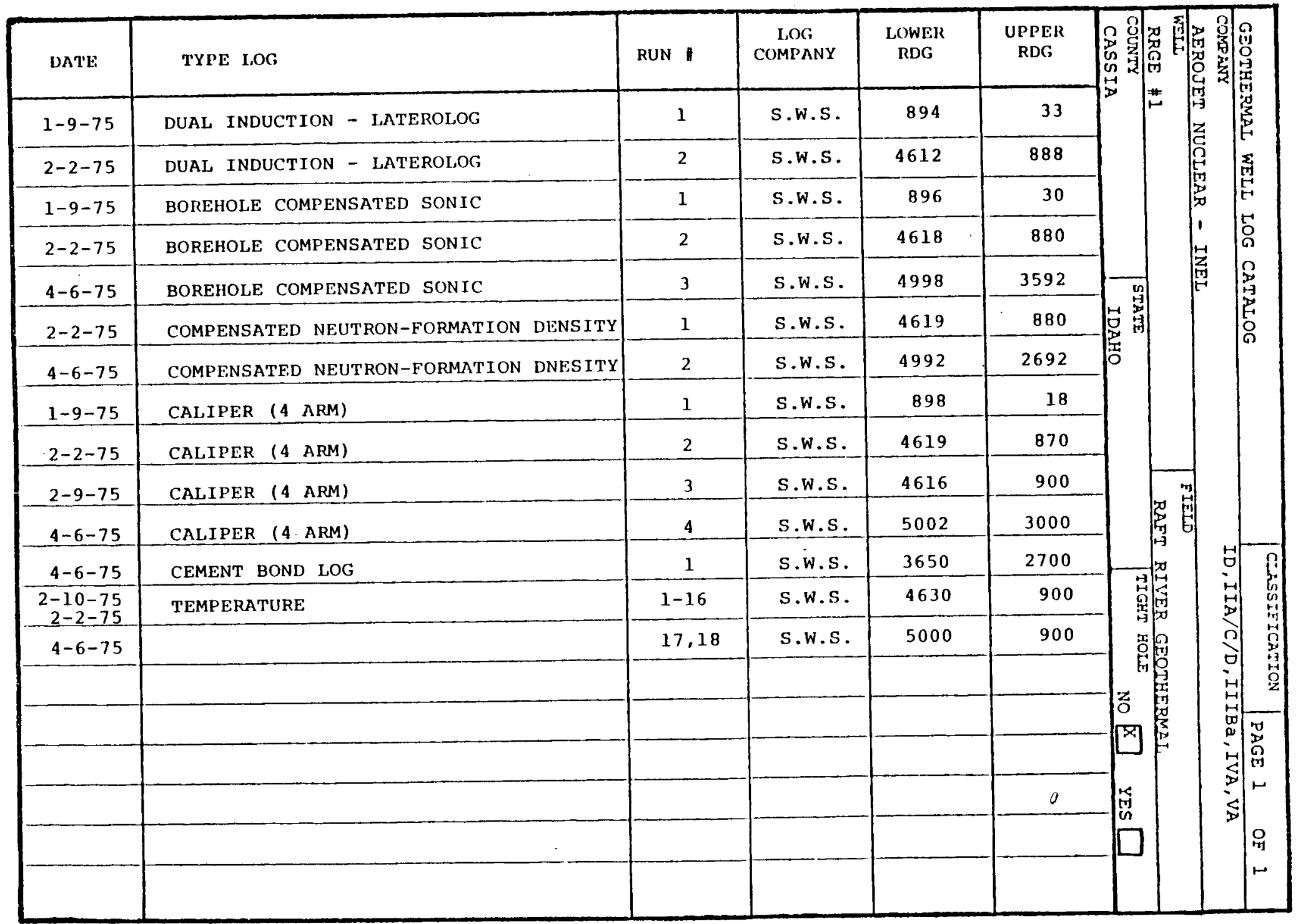




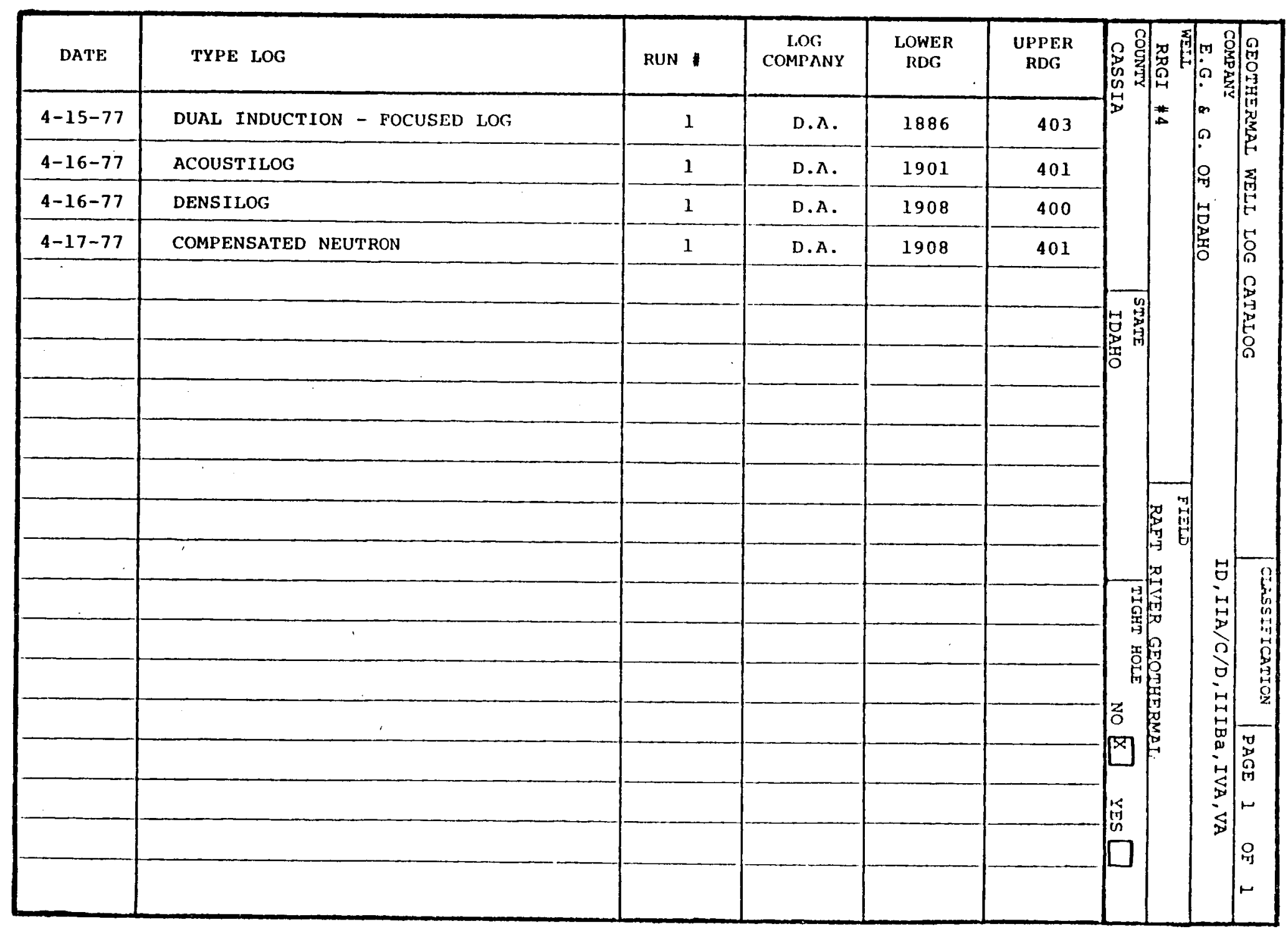




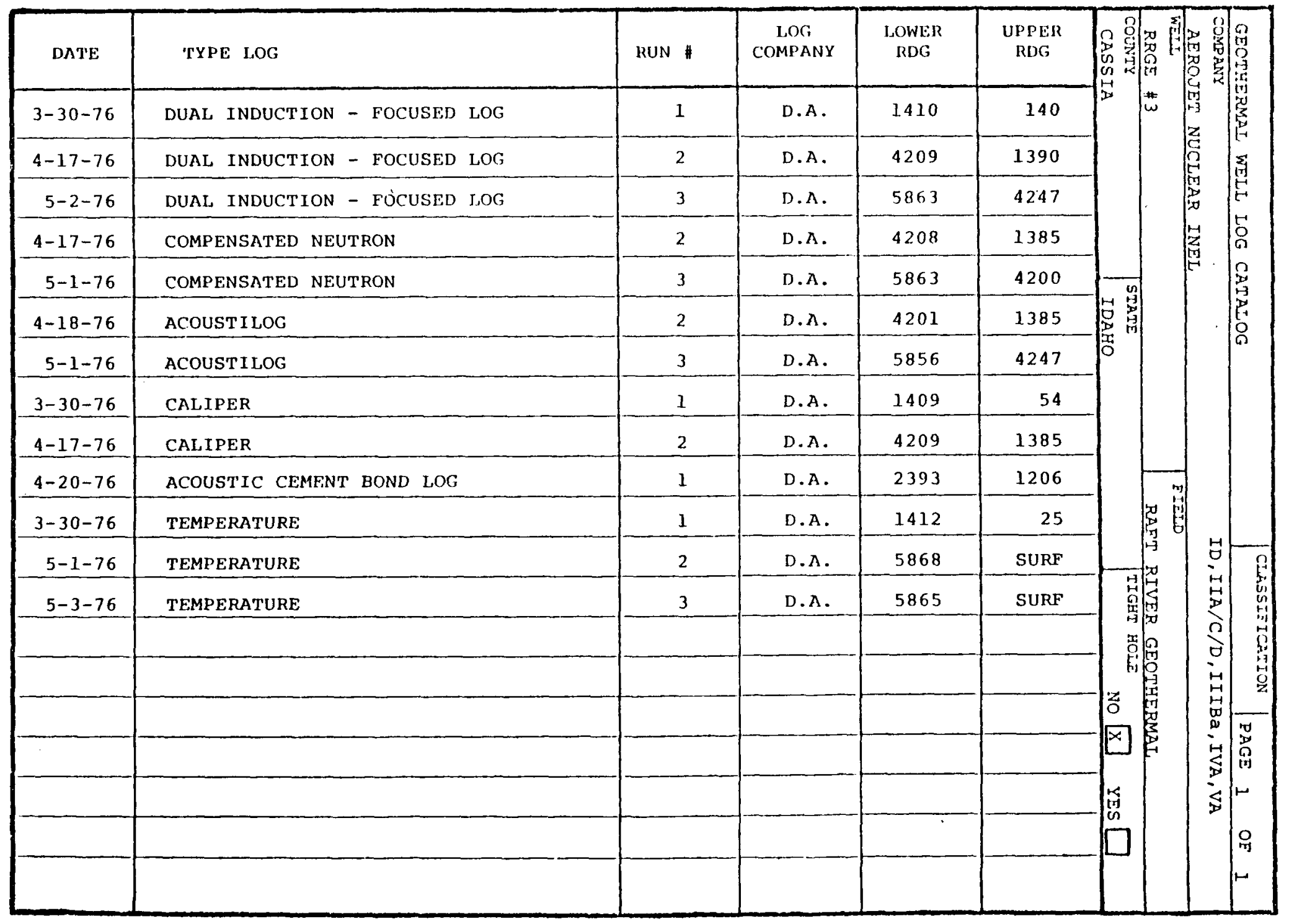




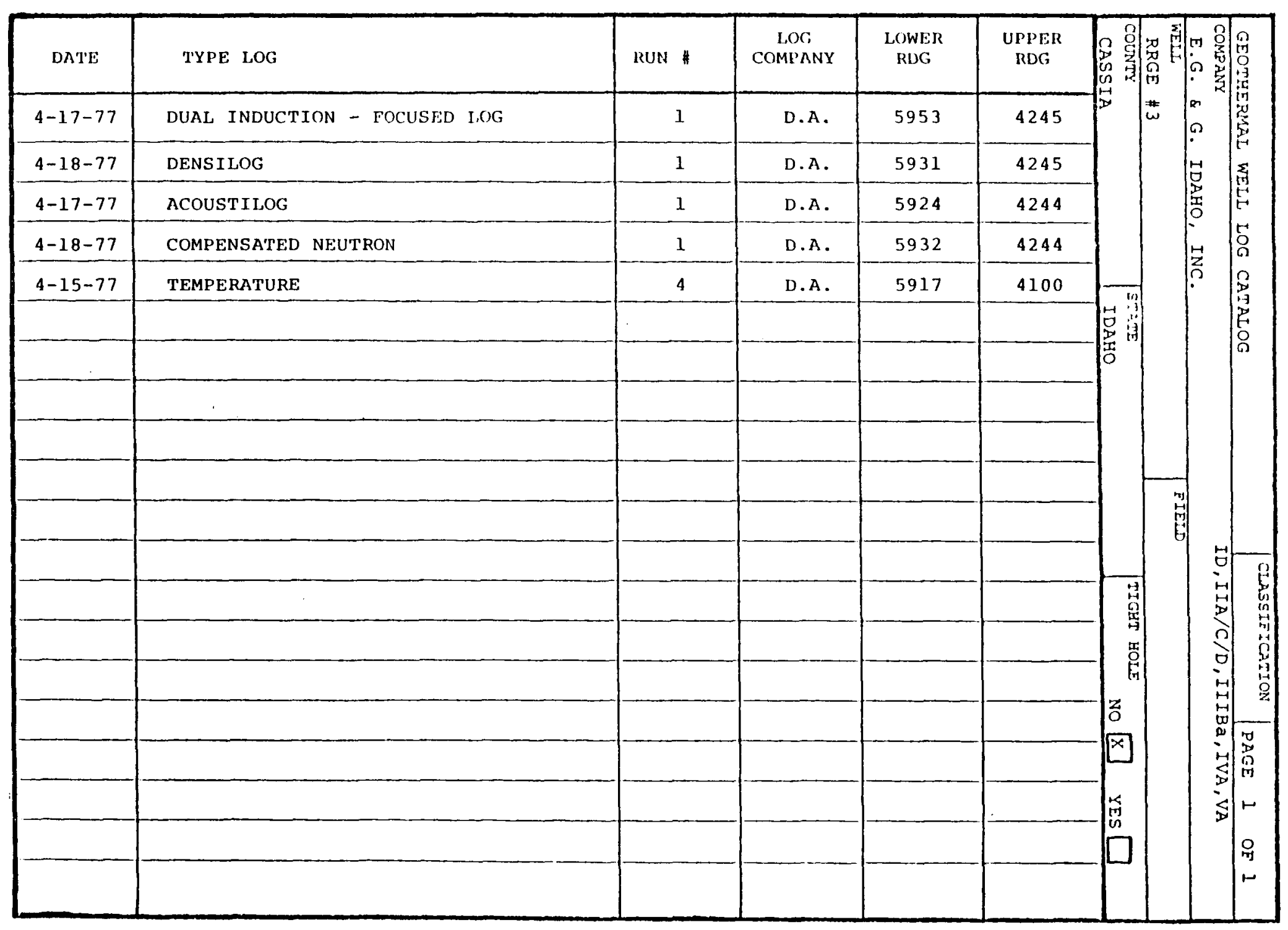




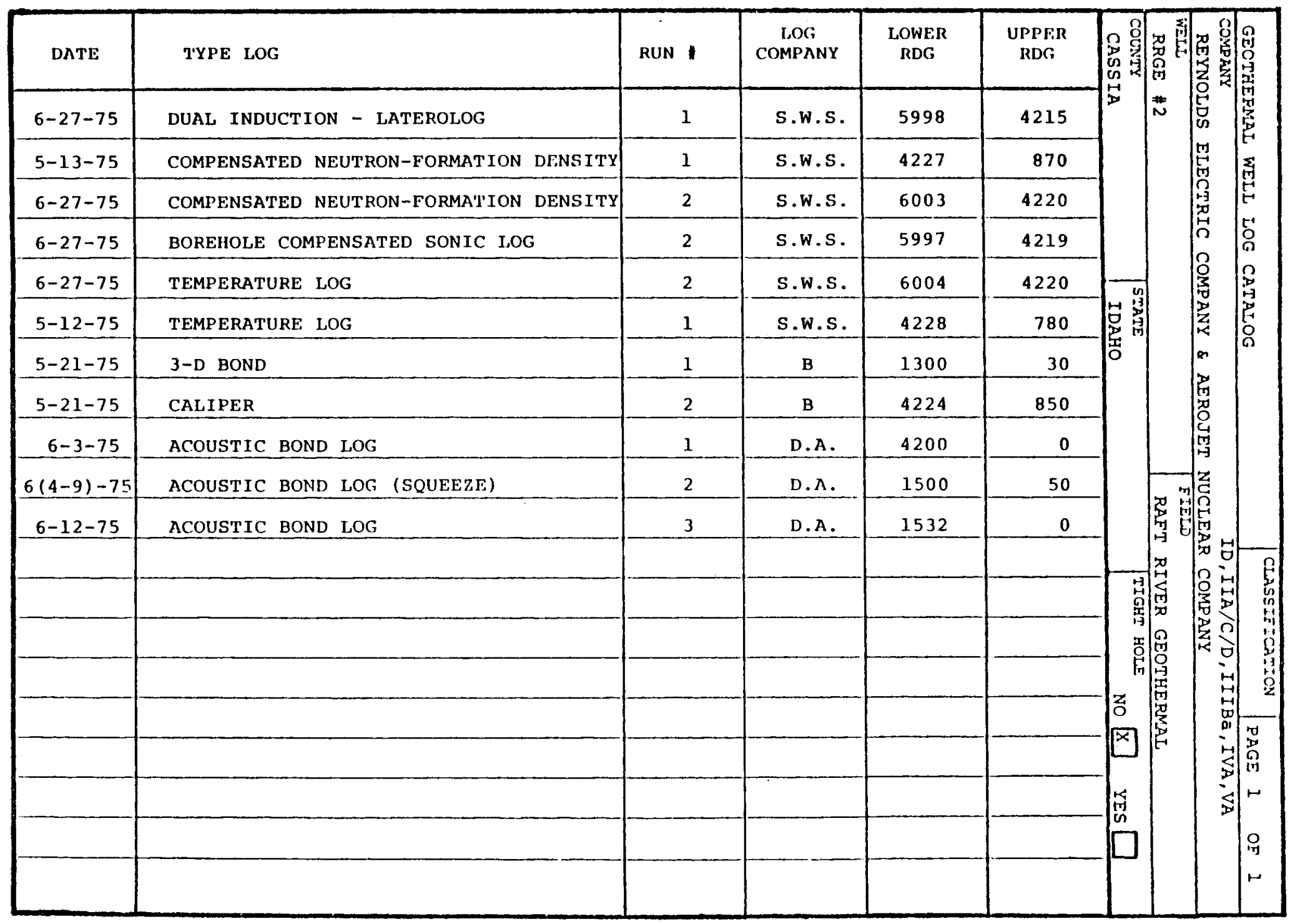




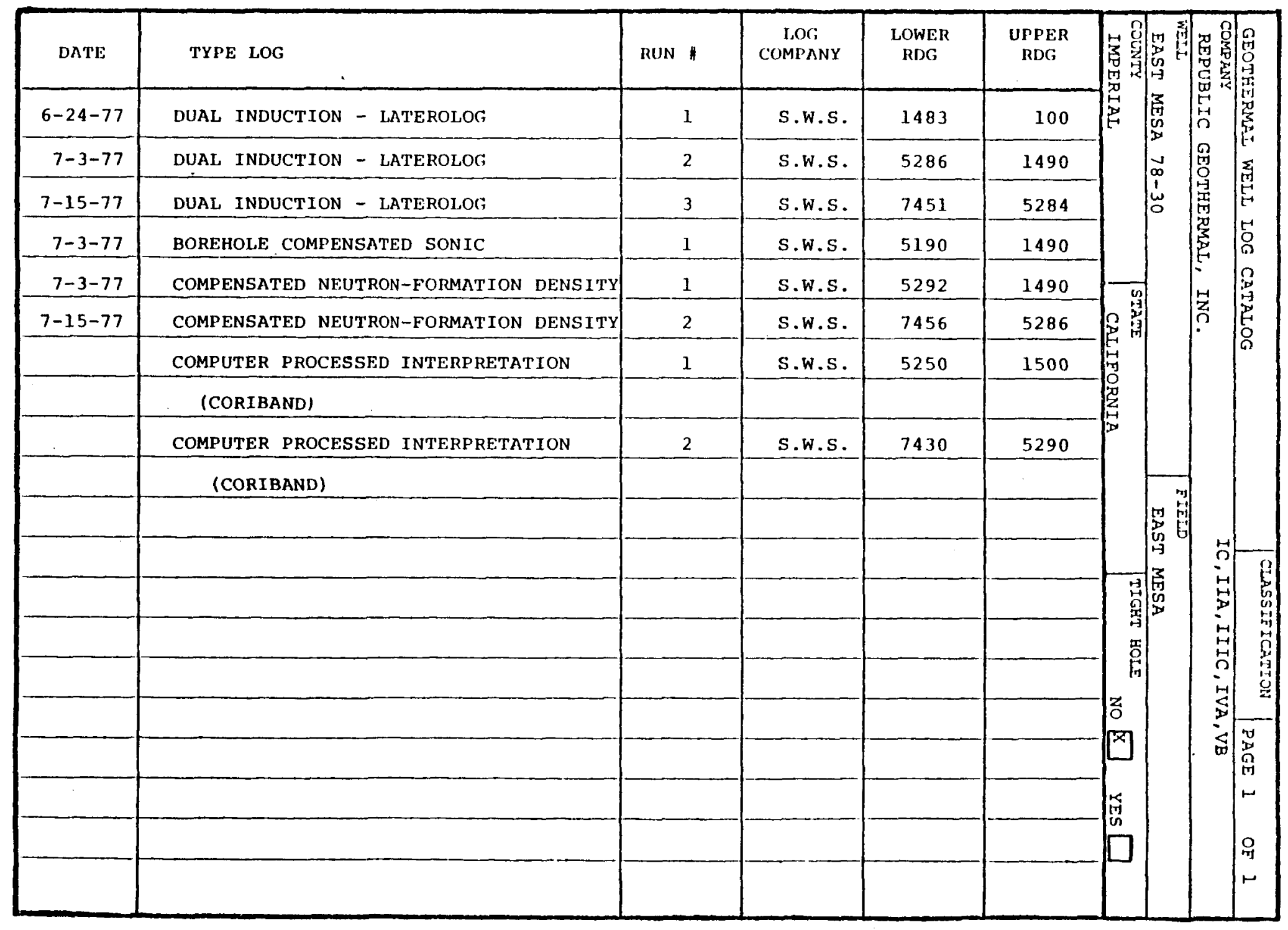




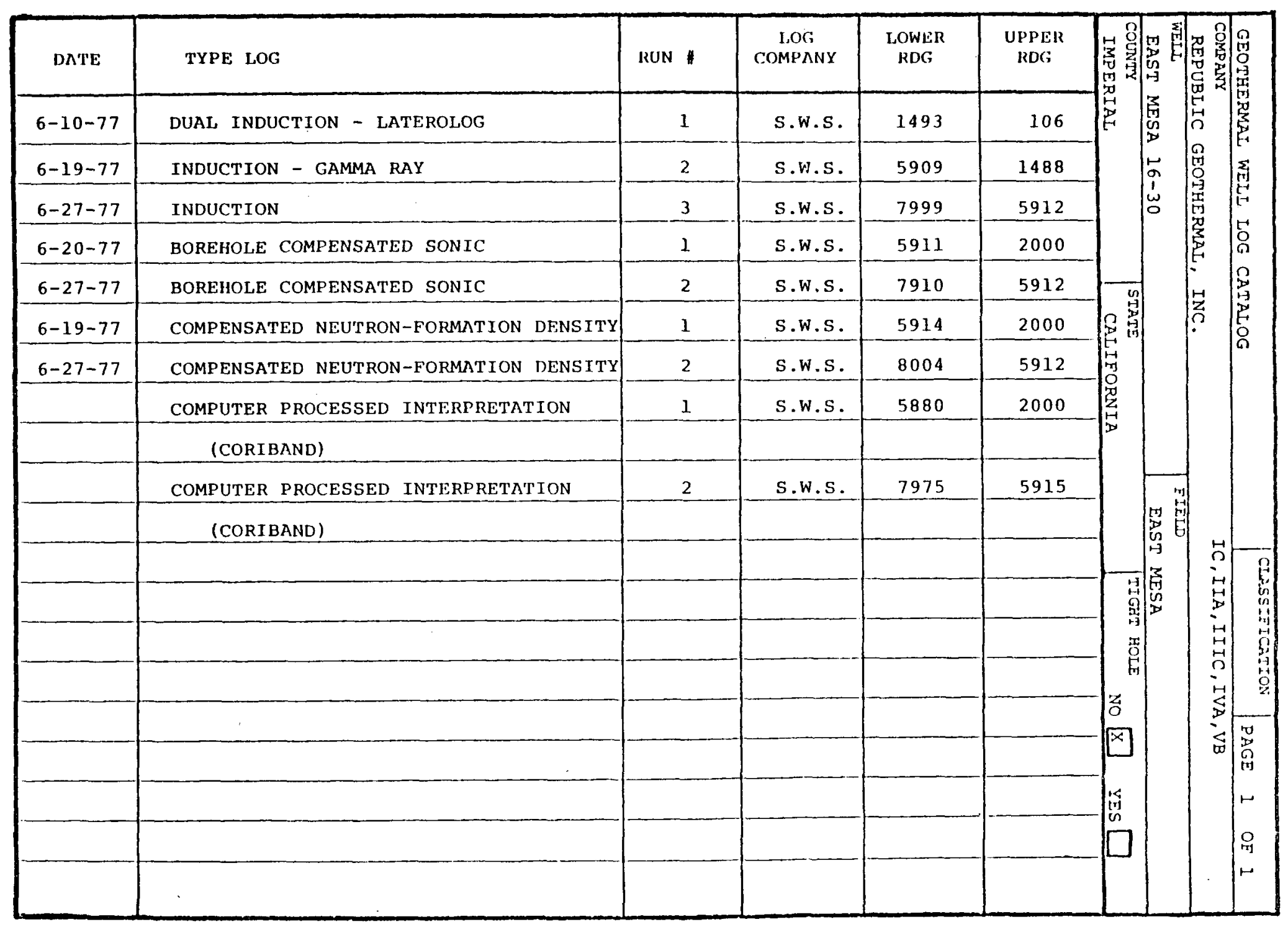




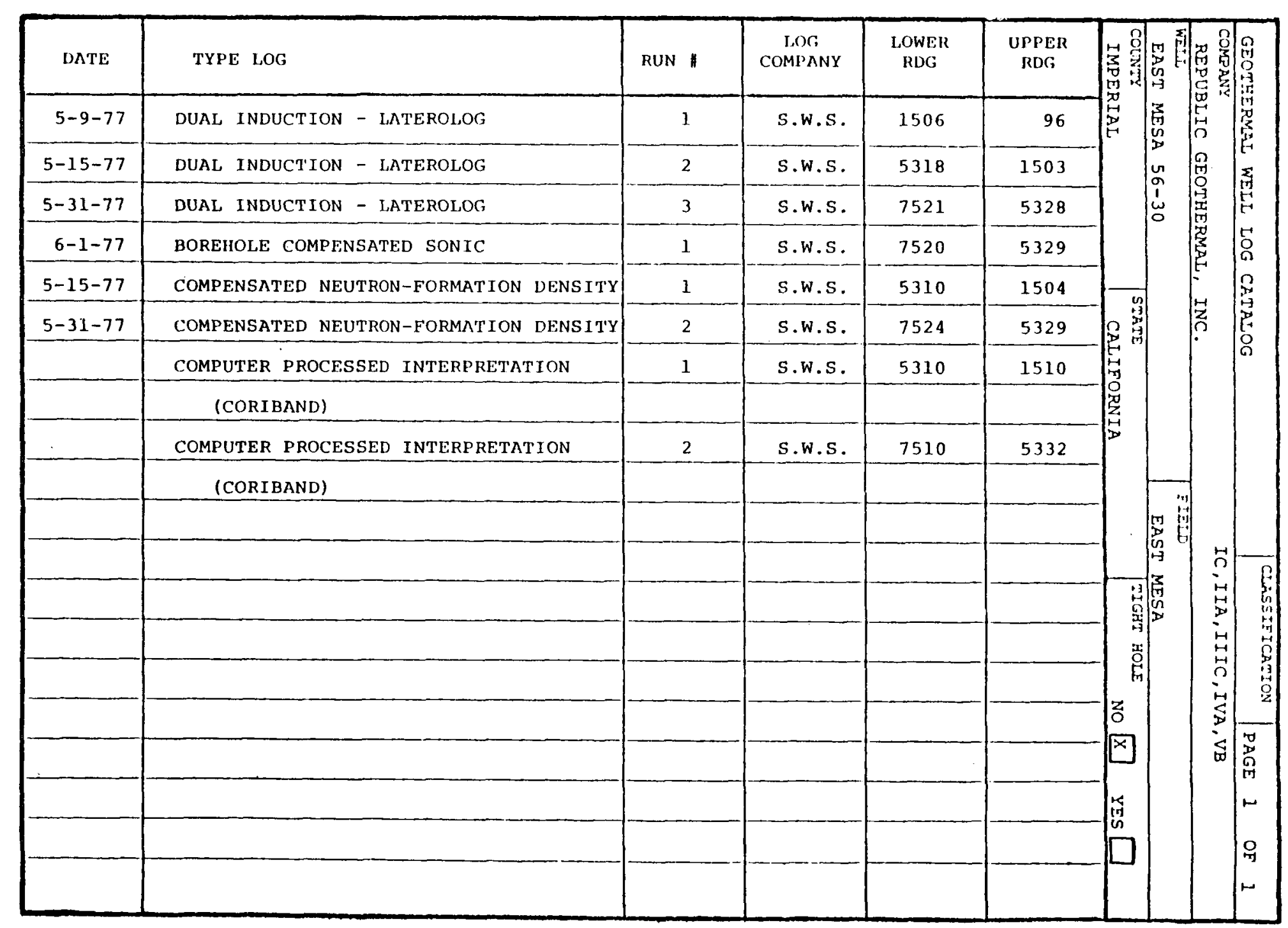




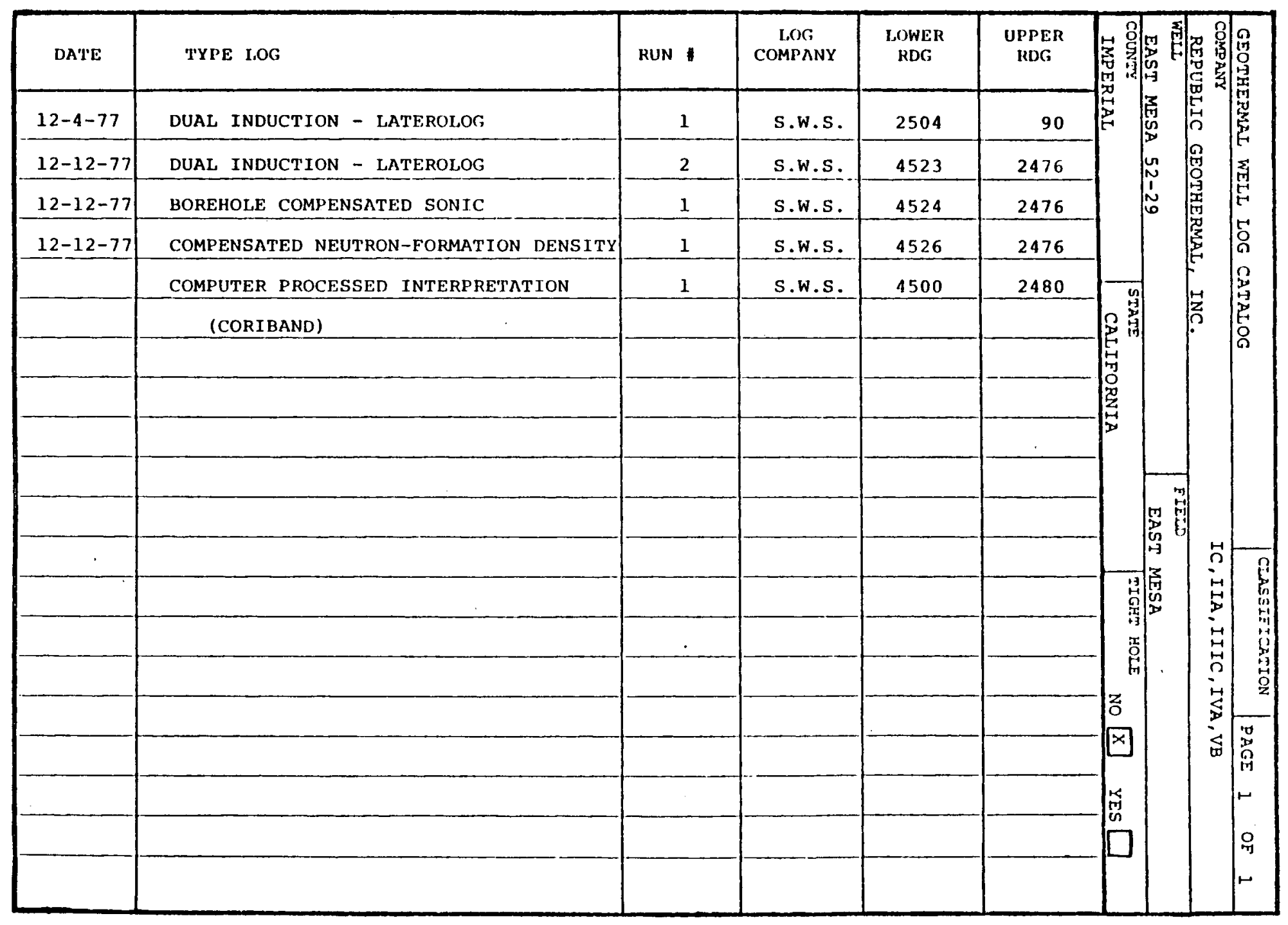




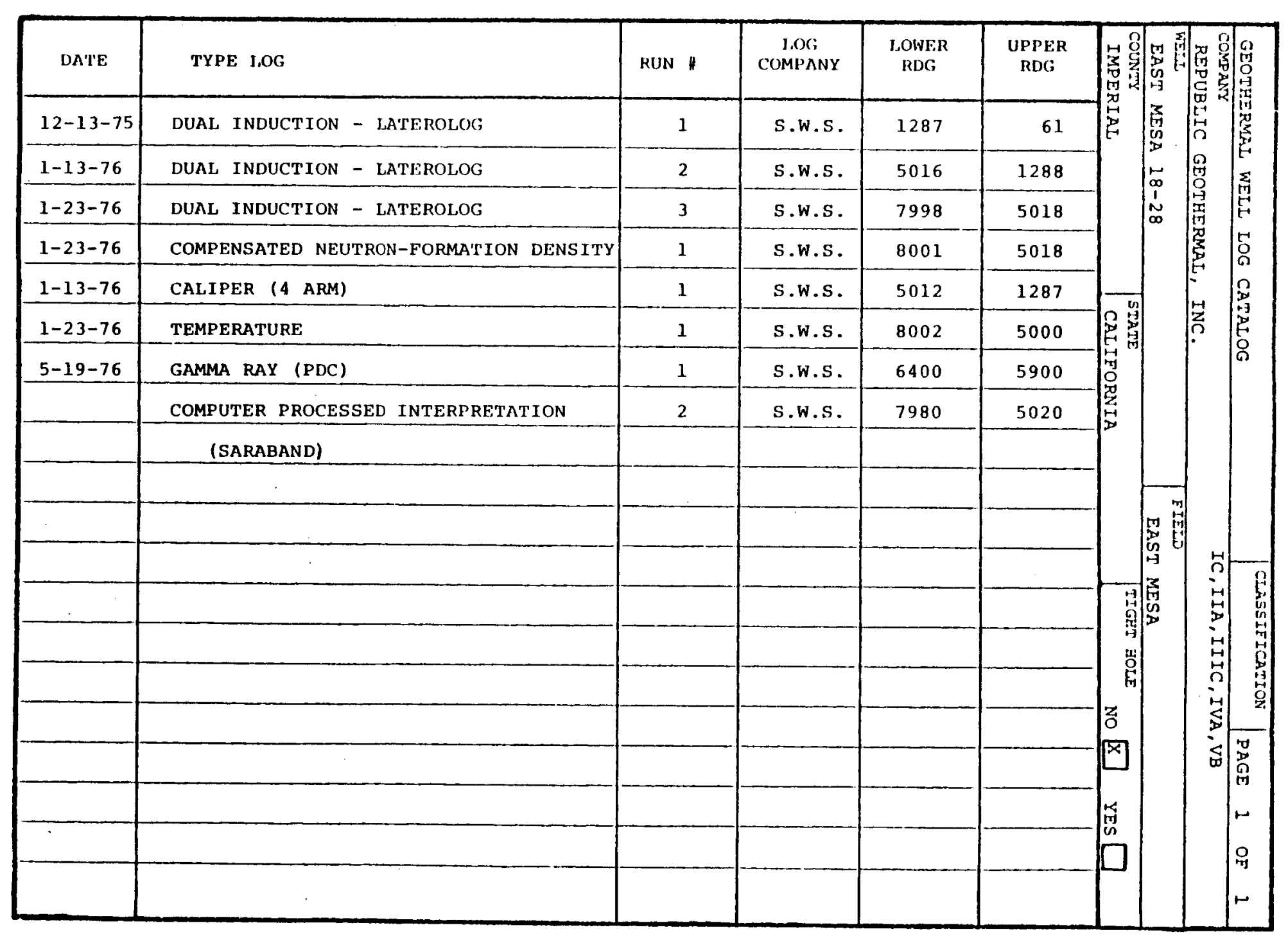




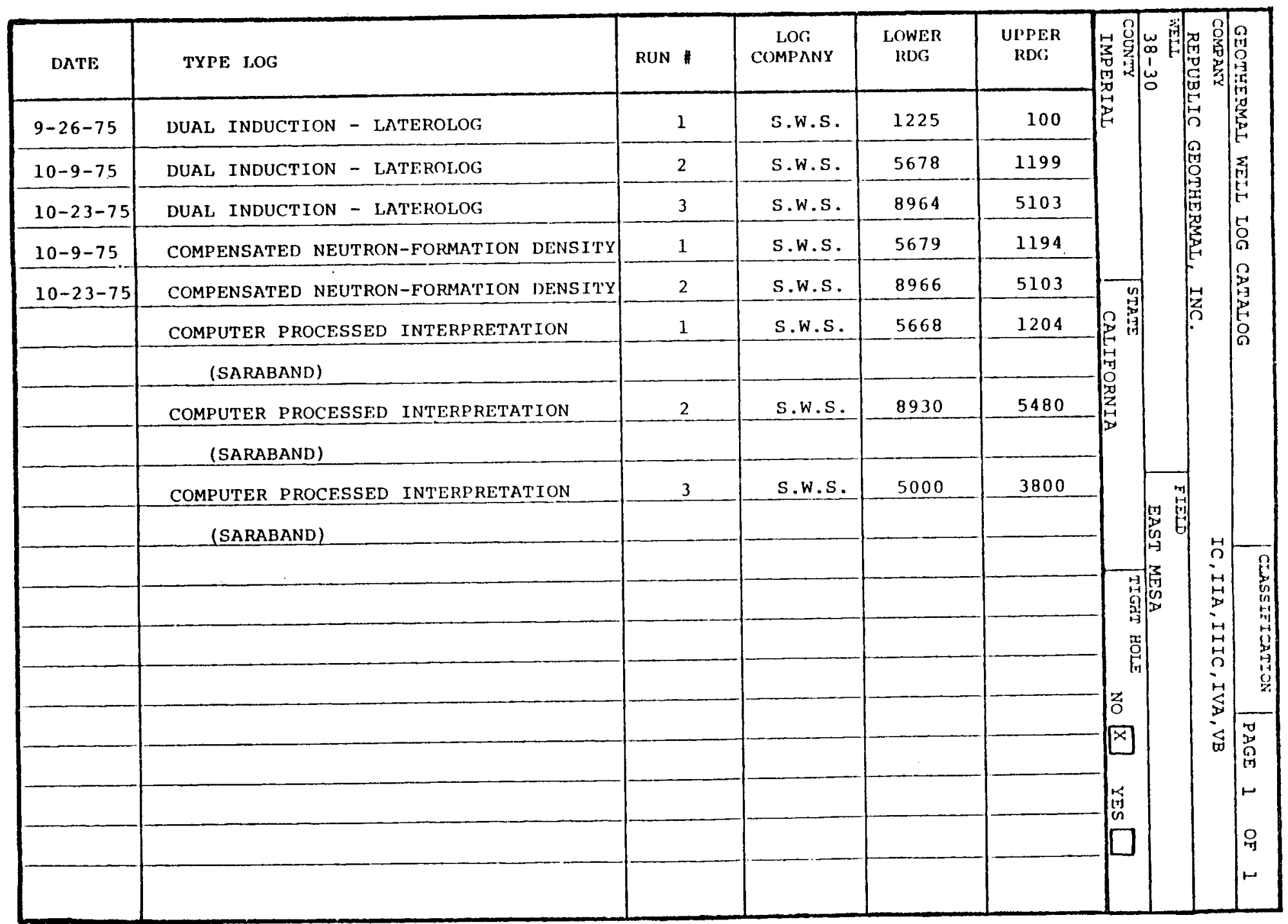




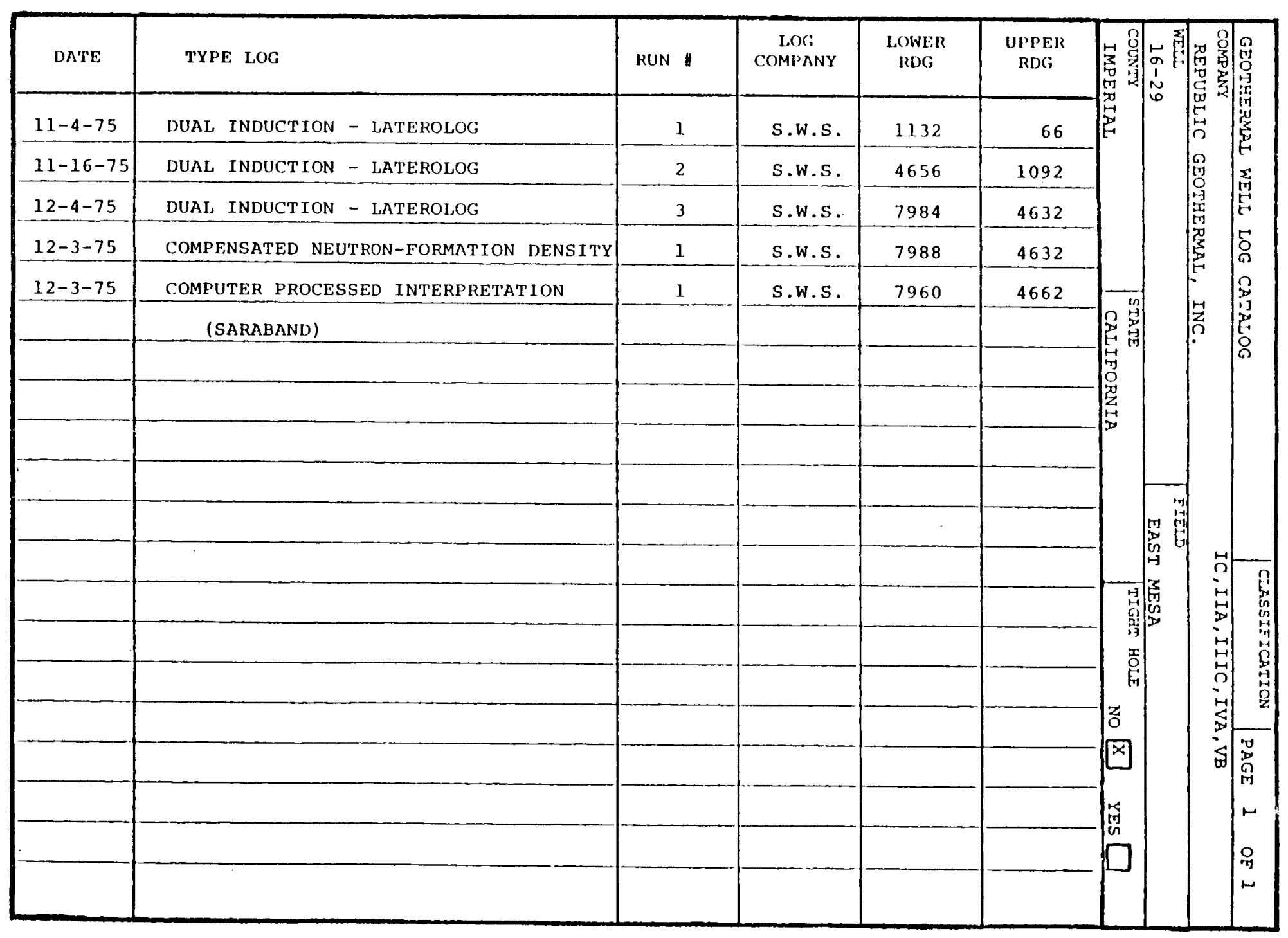




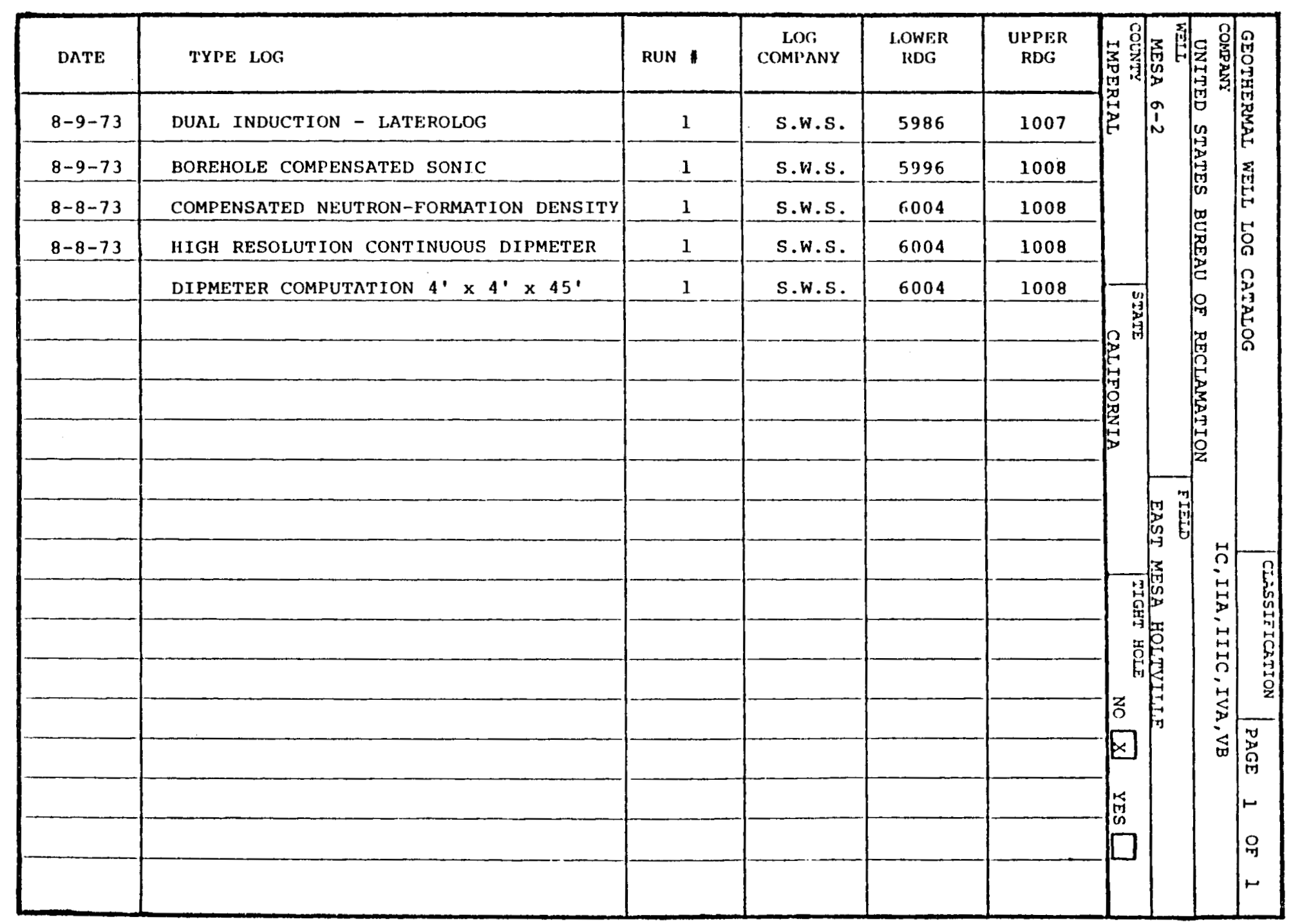




\begin{tabular}{|c|c|c|c|c|c|c|c|c|c|}
\hline DNTE & TYPE LOG & RUN & $\begin{array}{c}\text { LOG } \\
\text { COMPANY }\end{array}$ & $\begin{array}{l}\text { LOWER } \\
\text { RDG }\end{array}$ & $\begin{array}{l}\text { UPPER } \\
\text { RDG }\end{array}$ & & \multirow{5}{*}{ 歌 } & \multirow{5}{*}{ 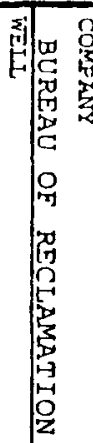 } & \multirow{2}{*}{ 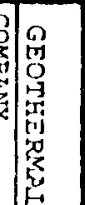 } \\
\hline $5-1-74$ & DUAL INDUCTION - LATEROLOG & 1 & s.w.s. & 6018 & 1026 & & & & \\
\hline $5-2-74$ & BOREIOLE COMPENSATED SONIC LOG & 1 & s.w.s. & 6013 & 1024 & & & & $\sum_{0}^{2}$ \\
\hline $5-2-74$ & COMPENSATED NEUTRON-FORMATION DENSI'TY & 1 & S.w.S. & 6024 & 1027 & & & & te \\
\hline $5-2-74$ & HIGH RESOLUTION CONTINUOUS DIPMETER & 1 & S.w.s. & 6009 & 3452 & & & & 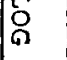 \\
\hline & COMPUTER PROCESSED INTERPRETATION & 1 & s.w.s. & 6006 & 1060 & & & & 趸 \\
\hline & (SARABAND) & & & & & $\mid$ & & & $\int_{0}^{8}$ \\
\hline & & & & & & & & & \\
\hline & & & & & & 䠌 & & & \\
\hline & & & & & & $D$ & & & \\
\hline & & & & & & & & & \\
\hline & & & & & & & $\mid$ & & \\
\hline & & & & & & & F & s. & $\Gamma$ \\
\hline & & & & & & 搨 & 孞 & $\stackrel{-H}{5}$ & 量 \\
\hline & & & & & & 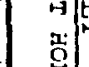 & 传 & 点 & 年 \\
\hline & & & & & & Fi & & $n_{n}^{n}$ & 苟 \\
\hline & . & & & & & ŏ & & 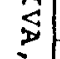 & 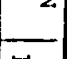 \\
\hline & & & & & & $x$ & & $\overleftrightarrow{\varpi}$ & 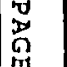 \\
\hline & & & & & & sis & & & $r$ \\
\hline & & & & & & nn & & & O \\
\hline & & & & & & & & & a \\
\hline
\end{tabular}




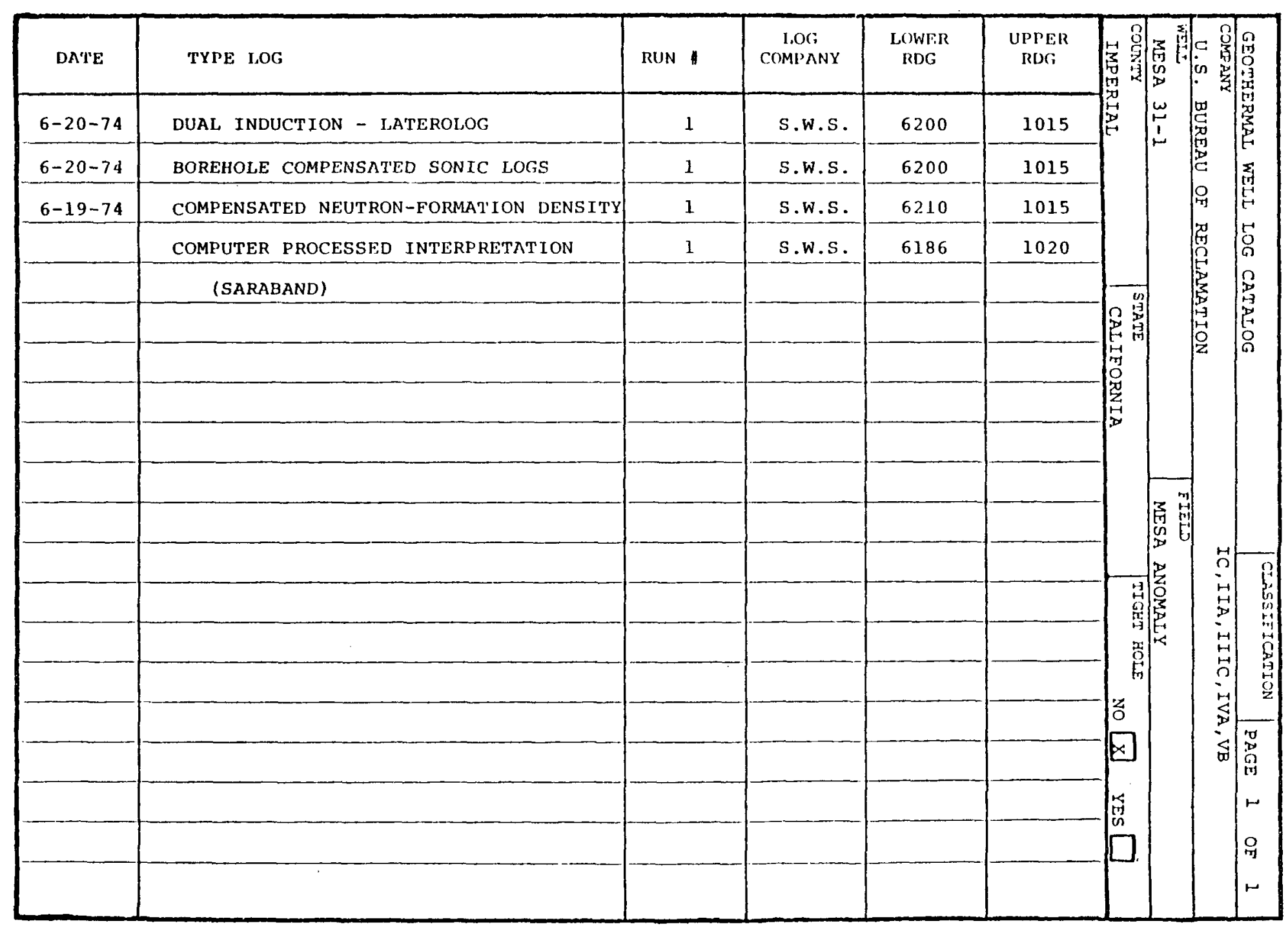




\begin{tabular}{|c|c|c|c|c|c|c|c|c|c|}
\hline INATE & TYPE LOG & RUN & $\begin{array}{c}\text { LOG } \\
\text { COMPANY }\end{array}$ & $\begin{array}{c}\text { LOWER } \\
\text { RDG }\end{array}$ & $\begin{array}{l}\text { UPPER } \\
\text { RDG }\end{array}$ & \multirow{2}{*}{ 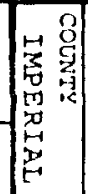 } & & \multirow{2}{*}{ 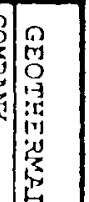 } \\
\hline $7-1-72$ & DUAL INDUCTION - LATEROLOG, & 1 & s.w.s. & 2500 & 378 & & & & \\
\hline $7-30-72$ & DUAL INDUCTION - LATEROLOG & 2 & s.w.s. & 7286 & 2505 & & & 胥 & $\sum_{11}$ \\
\hline $8-13-72$ & DUAL INDUCTION - LATEROIOG & 3 & s.w.s. & 8023 & 7292 & & & ry & $\mid r$ \\
\hline $7-2-72$ & BOREHOLE COMPENSATED SONIC LOG & 1 & s.w.s. & 2495 & 378 & & & & 号 \\
\hline $7-30-72$ & BOREHOLE COMPENSATED SONIC LOG & 2 & S.w.s. & 7280 & 2505 & 光 & & 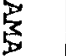 & 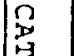 \\
\hline $8-14-72$ & BOREHOLE COMPENSATED SONIC LOG & 3 & s.w.s. & 8014 & 7292 & $\mid$ & & 0 & 层 \\
\hline $7-2-72$ & COMPENSATED NEUTRON-FORMATION DENS ITY & 1. & s.w.s. & 2502 & 22 & T1] & & & \\
\hline $7-30-72$ & COMPENSATED NEUTRON-FORMATION DFNSITY & 2 & s.w.s. & 7394 & 8027 & F & & & \\
\hline $8-14-72$ & COMPENSATED NEUTRON-FORMATION DENS ITY & 3 & S.w.s. & 8027 & 7292 & & & & \\
\hline $7-30-72$ & TEMPERATURE LOG & 1 & s.w.s. & 4726 & 200 & & & & \\
\hline & COMPUTER PROCESSED INTERPRETATION & 1 & s.w.s. & 2485 & 380 & & & & \\
\hline & (SARABAND) & & & & & & & & $p$ \\
\hline & COMPUTER PROCESSED INTERPRETATION & 2 & S.w.s. & 7290 & 2510 & & & 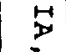 & 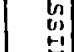 \\
\hline & (SARABAND) & & : & & & & & 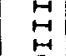 & 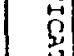 \\
\hline & COMPUTER PROCESSED INTERPRETATION & 3 & s.w.s. & 8000 & 7332 & & & 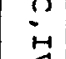 & 8 \\
\hline & (SARABAND) & & & & & & & $\$$ & $\pi$ \\
\hline & & & & & & & & $\infty$ & 盟 \\
\hline & & & & & & 泴 & & & 1 \\
\hline & & & & & & 7 & & & P \\
\hline & & & & & & & & & $r$ \\
\hline
\end{tabular}




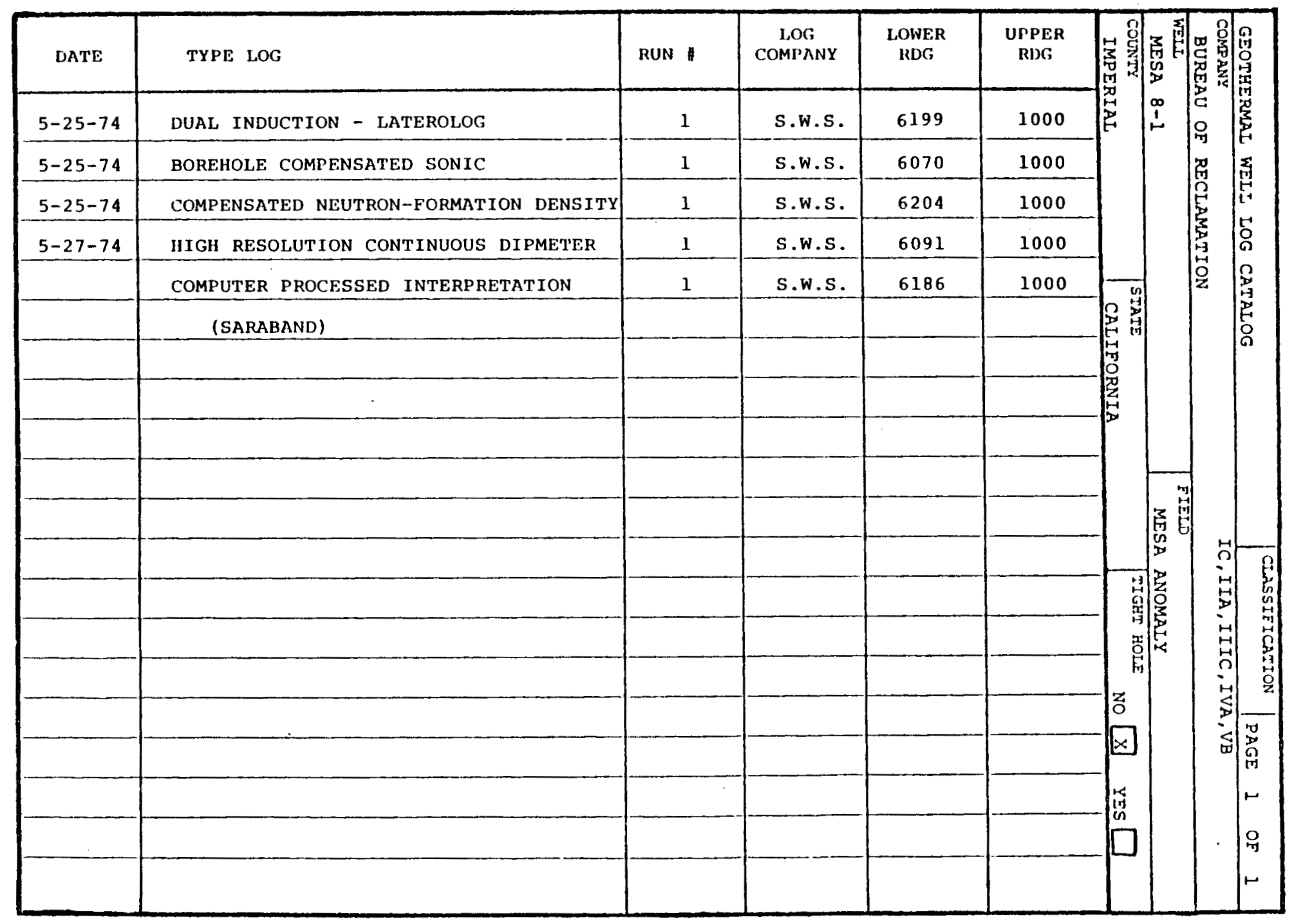




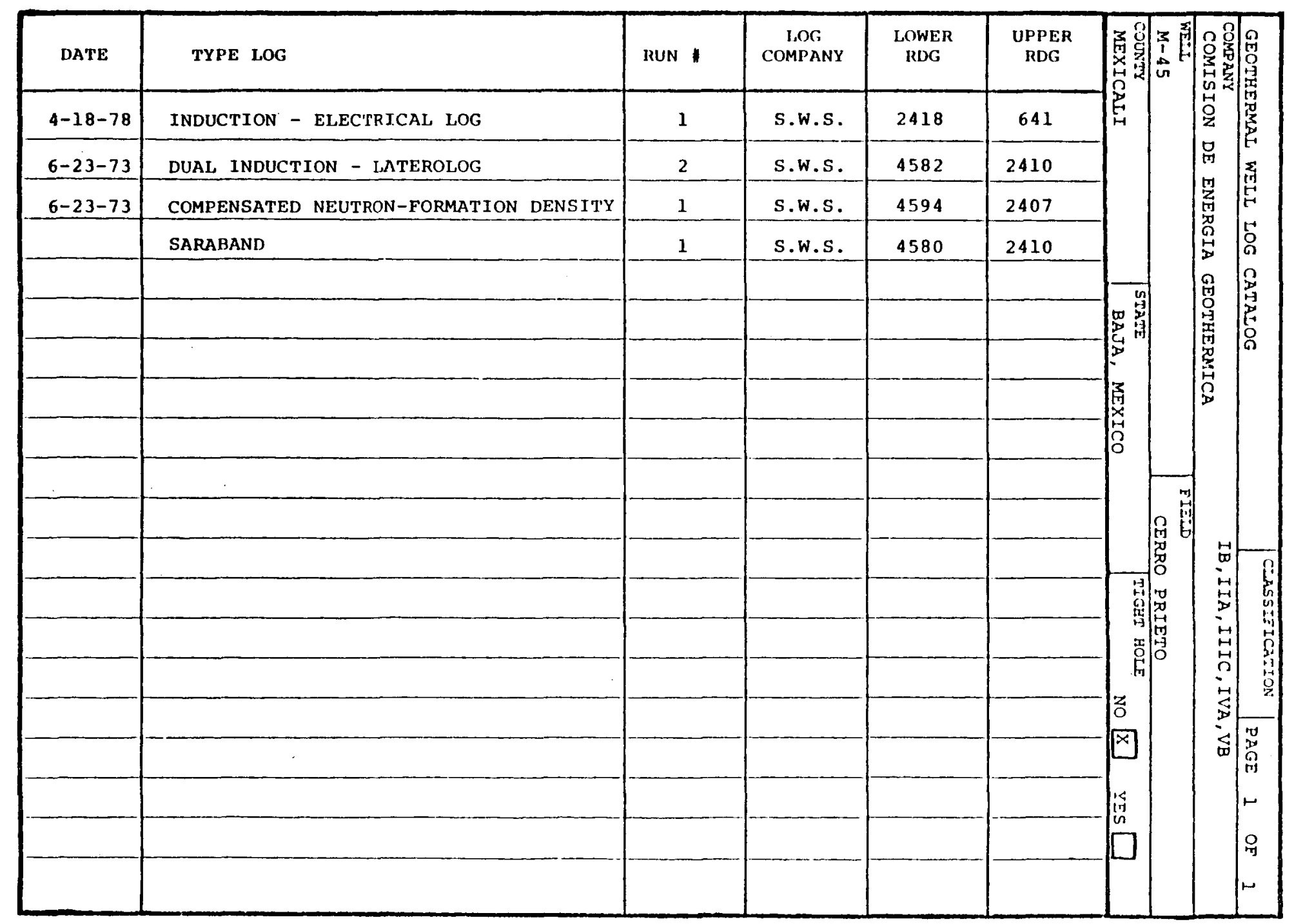


NOTES 


\section{B. Literature Search}

Computerized literature searches were made in various data files. The pertinent references discovered are listed on the following pages. Although all of the listed works do not deal directly in their entirety with log analysis of geothermal well logs, many contain references to valuable information in related fields. 
Aamodt, R. Lee, "The Los Alamos Scientific Laboratory Hot Dry Rock Geothermal Energy Program Abstract," Guidebook of Monument Valley and Vicinity, Arizona and Utah, ed. H. L. James, New Mexico Geological Society, Annual Field Conference Guidebook, No. 24 (1973).

Agnew, B. G., "Evaluation of Fracture Treatments with Temperature Surveys," Journal of Petroleum Technology (July 1966).

Albright, J. N., "New and More Accurate Method for the Direct Measurements of Earth Temperature Gradients in Deep Boreholes," Proceedings of 2nd U.N. Geothermal symposium, San Francisco, CA, May 19-29, 1975 .

Albright, J. N., and Hanold, R. J., "Seismic Mapping of Hydraulic Fractures made in Basement Rocks," 2nd ERDA Enhanced Oil and Gas Recovery Symposium Proceedings, Volume 2 (1976).

Albright, J. N., "Temperature Measurements in the Precambrian Section of Geothermal Test Hole No. 2," Los Alamos Scientific Laboratory Report LA-6022-MS (July 1975).

Alfold, I. I., and Galfi, J., "Hungary-Methodological Problems of Geothermal Measurements," International Association Science Hydrology Bulletin (in French) (November 1, 1966).

Altseimer, J. H., "Geothermal Well Technology and Potential Applications of Subterrene Devices: A Status Review," Los Alamos Scientific Laboratory Report LA-5689-MS (July 1974).

Baba, K., Takaki, S., Matsuo, G., and Katagiri, K., "A Study of the Reservoir at the Matsukawa Geothermal Field," Geothermal Special Issue, Volume 2, Part 2 (1970).

Baker, L. E., Baker, R. P., and Hughen, R. I., "Report of the Geophysical Measurements in Geothermal Wells Workshop, Airport Marina Hotel, Albuquerque, New Mexico, September 17-19, 1975," Sandia Laboratory Report No. SAND--75-0608 (December 1975).

Baker, L. E., Campbel1, A. B., and Hughen, R. L., "Geothermal Well Logging: An Assessment of the State of the Art," The Log Analyst, Volume 16, No. 6 (November-December 1975).

Baker, L. E., Campbel1, A. B., and Hughen, R. L., "Well Logging Technology and Geothermal Applications: A Survey and Assessment with Recommendations," Sandia Laboratories Report No. SAND--75-0275 (May 1975), 75 pages. 
Beck, A. E., "The Use of Temperature Gradients in Stratigraphic Correlations," Society Exploration Geophysics, 44th Annual International Meeting, Geophysics, Volume 40 , No. 1 (1975).

Bench, N. D., "Well Measurements," United Nations Educational, Scientific and Cultural Organization, Paris (1973).

Bird, J. M., "Interpretation of Temperature Logs in Waterand Gas-Injection Wells and Gas-Producing Wells," Bird Well Surveys (1954).

Blackwell, D. D., "Heat-Flow Determinations in the Northwestern United States," Journal Geophysical Research Volume 74, No. 4 (February 15, 1969).

Blair, A. G, Tester, J. W., and Mortensen, J. J., "IASL Hot Dry Rock Geothermal Project, Progress Report, July 1, 1975 June 30, 1976," Los Alamos Scientific Laboratory Report I.A--6525-PR (October 1976).

Bodvarssun, G., "Temperature Inversions in Geothermal systems," Geoexploration, Volume 11 (September 1973).

Brown, D. W., and Potter, R. M., "LASL Geothermal Energy Program: Summary of In Situ Experiments in the First Exploratory Hole," American Geophysical Union 1973 Fall Annual Meeting.

Burge, E. J., "Mud Temperature Study Important CWLS Project," Oilweek, Volume 16, No. 25 (August 16, 1965).

Carroll, R. D., "Applications of Inhole Geophysical Logs in Volcanic Rocks, Nevada Test Site," The Geological Society of America, Memoir 110 (1968).

Carvalho, H. S., and Vacquier, V., "Method for Determining Terrestial Heat Flow in Oil Fields," Geophysics, Volume 42 , No. 3 (April 1977).

Cermak, V., Kresl, M., and Vesely, I., "Experimental Determination of the Coefficient of Heat Transfer During Hole Boring and the Re-establishment of the Temperature Field Equilibrium," Earth Planetary Scientific Letter, Volume 5, No. 3 (November 1968).

Cocanower, R. D., Morris, B. P., and Dillingham, M., "Computerized Temperature Decay - An Asset to Temperature Logging," Journal of Petroleum Technology (1969).

Costain, J. K., and Wright, P. M., "Heat Flow and Precision Temperature Measurements in Boreholes," 10 th Annual SPWLA Logging Symposium Transactions (1969). 
Crosby, J. W., III, and Anderson, J. V., "Some Applications of Geophysical Well Logging to Basalt Hydrogeology," Washington State University Pullman, Ground Water, Volume 9 (SeptemberOctober 1971).

Csaba, J., Nemeth, F., and Szabo, J., "On Determining Temperatures in Deep Wells," Koolaj Foldgaz Volume 3, No. 1 (in Hungarian) (January 1970).

Curtis, M. R., and Witterholt, E. J., "Use of the Temperature Log for Determining Flow Rates in Producing Wells," 48th Annual Society of Petroleum Engineers of AIME Fall Meeting, Preprint No. SPE-4637 (1973).

Diment, W. H., "Thermal Regime of a Large Diameter Borehole Instability of the Water Column and Comparison of Air- And Water-Filled Conditions," Geophysics, Volume 32, No. 4 (August 1967).

Dorfman, M. H., Oskay, M. M., and Gaddis, M. P., "SelfPotential Profiling--A New Technique for Determination of Heat Movement in a Thermal Oil Recovery Flood," 52nd Annual Society of Petroleum Engineexs of AIME Fall Technology Conference, Preprint No. SPE-6783 (1977).

Dowdle, W. L., and Cobb, W. M., "Estimation of static Formation Temperature from Well Logs," 49th Annual Society of Petroleum Engineers of AIME Fall Meeting, Preprint No. SPE5036 (1974).

"Drilling Plan: Raft River Geothermal Exploratory Hole No. 3," ERDA Idaho Operations Office Report No. I00-10064, 47 (Invo--170) (February 1976).

d'Yakunov, D. I., "Problem of Determining Principal Geothermal Parameters," Geol. Nefti Gaza (September 1961).

Finzi-Contini, G., and Veliciu, S., "Electrical Parameters for Clay Samples in the Frequency and Temperature Dependence (First Results)," Geothermics, Volume 3, No. 1 (March 1974).

Garrison, L. E., "Geothermal Steam in the Geysers--Clear Lake Region California," Geological Society America Bulletin, Vol. 83, No. 5 (May 1972).

Gilarranz, S., and Schoeppel, R. J., "Use of Well Log Temperatures as a Criterion for the Evaluation of Regional Geothermal Gradients - Test Case, Oklahoma," 40 th Annual Society of Petroleum Engineers of AIME Fall Meeting, Preprint No. SPE 1297. 
Goss, R., Combs, J., and Timur, A., "Prediction of Thermal Conductivity in Rocks from Other Physical Parameters and from Standard Geophysical Well Logs," l6th Annual SPWLA Logging Symposium Transactions (1975).

Goss, R., and Combs, J., "Thermal Conductivity Measurement and Prediction from Geophysical Well Log Parameters with Borehole Application," Report No. Contrib-291, NSF/RA$760364, \mathrm{~PB}-262,372 / 6 \mathrm{GA}$ (1976).

Goss, Ronald, and Combs, Jim, "Thermal Conductivity of Sediments From Drill Chips, Cores, and Geophysical Log Parameters Abstract," EOS (American Geophysical Union, Transactions), Volume 55, No. 4 (1974).

Gretener, P. E., "On the Thermal Instability of Large Diameter Wells--An Observational Report," Geophysics, Volume 32, No. 4 (August 1967).

Grisafi, T. W., Rieke, H. H., III, and Skidmore, D. R., "Approximation of Geothermal Gradients in Northern West Virginia, Using Bottom-Hole Temperatures from Electric Logs," AAPG Bulletin, Volume 58, No. 2 (February 1974).

Hedemann, H. A., "Contributions to Geothermics in Deep Wells," Freiberger Forsch, Ser. C, No. 238 (in German) (1968).

Hobson, D. C., Beck, A. E., and Findlay, D. C., "Notes on Geophysical Logs and Bore-Hole Temperature Measurements from the Muskox Drilling Project," Canadian Geological Survey Paper No. 66-13 (1966).

Howell, E. P., "Borehole Thermal Conductivity Measurements," Atlantic Richfield (April 9, 1974).

Hurtig, E., and Schlosser, P., "Investigation of the Terrestial Heat Flow in the DDR," Gerlands Beitr Geophys, Volume 84 , Nos. 3-4 (in German) (1975).

Itenberg, S. S., "Study of Fractured Reservoirs With the Help of Well-Logging Techniques," Bulletin, National Geophysical Research Institute (1969).

Joyner, H. D., "A Correlation of Electric-Log-Indicated Reservoir Temperature with Actual Reservoir Temperature-Southwest Louisiana," Journal of Petroleum Technology, Volume 27 (February 1975).

Kappelmeyer, O., and Haenel, R., "Geothermics with Special Reference to Application," Geoexplor. Monogr. Ser. 1, No. 4 $(1974), 248$ pages. 
Keller, George V., "Research Drill Hole at the Summit of Kilauea Volcano, Hawaii," The Utilization of Volcano Energy, Sandia Laboratory, Albuquerque, New Mexico (1974).

Keller, G. V., Murray, J. C., and Towle, G. H., "Geophysical Logs from the Kilauea Geothermal Research Drill Hole," 15th Annual SPWLA Logging Symposium Transactions 17 (1974).

Keller, H. H., Couch, E. J., and Berry, P. M., "Temperature Distribution in Circulation Mud Columns, SPE Journal, Volume 13, No. 1 (1973).

Kruger, P. and Ramey, H. J., Jr., "Workshop on Geothermal Reservoir Engineering Held at Stanford University on December 15-18, 1975," Stanford University Report No. SGP-TR-12, NSF/RA-760172 PR-261, 319/8GA (1976).

Kutasov, I. M., "Determination of the Time Required to Reach Temperature Equilibrium and to Establish the Geothermal Gradient in Deep Wells," Freiberger Forsch, Ser. C, No. 238 (in German) (1968).

Iittleton, R. T., and Burnett, E. E., "Salinity Profile of the East Mesa Field as Determined from Dual Induction Resistivity and SP Logs," Report No. EPA--600/9-76-011 (May 1976).

Manetti, G., "Attainment of Temperature Equilibrium in Holes During Drilling," Centro di Ricerca Geotermica, Pisa, Italy, Geothermics (February 3-4, 1972).

Mathias, K., and Lundberg, E. A., "East Mesa Test Wells," Geothermal Energy, Volume 3, No. 6 (1975).

Meidav, T., and Furgerson, R., "Resistivity Studies on the Imperial Valley Geothermal Area, California," Geothermics, Volume 1, No. 2 (June 1972).

Mercado, S., "High-Activity Hydrothermal Zones Detected by NA/K, Cerro Prieto, New Mexico," Geothermics Special Issue (1970).

Mercer, J. W., Jr., Faust, C., and Pinder, G. F., "Geothermal Reservoir Simulation," Advanced Research and Technology (1974).

Merkel, R. H., "The Generation of Thermal-Conductivity and Heat-Flow Logs From Conventional Borehole Logs," Society Exploration Geophysics, 44 th Annual International Meeting, Geophysics, Volume 40, No. I (1975).

Morgan, P., "Porosity Determinations and the Thermal Conductivity of Rock Fragments With Application to Heat Flow on Cyprus," Imperial College of Science and Technology, Earth Planet, SCI Letter (June 1975). 
Morris, B. P., and Cocanower, R. D., "Computers to Increase the Value of Temperature Logs," 9th Annual SPWLA Logging Symposium, New Orleans, Louisiana (1968).

Murphy, H. D., "Fluid Injection Profiles--A Modern Analysis of Wellbore Temperature Surveys," 52nd Annual Society of Petroleum Engineers cf AIME Fall Technology Conference, Preprint No. SPE-6783 (1977).

Noguchi, T., and Onodera, S., "Resistivity Exploration for Altered Zone $\bar{t} t$ Otake Geothermal Area - Japan," Bulletin Volcanol Volume 3s, No. 1 (1969).

Palmer, T. D., "Characterıstics of Geothermal Wells Located in the Salton Sea Geothermal Field, Imperial County, California," Lawrence Livermore Laboratory (December 15, 1975).

Peterson, F. L., and Sehgal, M. M., "Determining Porosity with Neutron Logs From Hawaiian Basaltic Aquifers," National Technical Information Service, Technical Report No. 8

(August 1974).

Peterson, Frank L., "Neutron Well Logging in Hawaii," Hawaii University Water Resource Research Center, Technical Report 75 (February 1974).

Pettitt, R. A., "Testing, Drilling, and Logging of Geothermal Test Hole GT-2, Phase III," Los Alamos Scientific Laboratory, New Mexico, Report LA-5965-PR (June 1975).

Radford, H. E., "Problems Encountered in Drilling Geothermal Steam Wells," Drilling Contract, Volume 2.1, No. 2 (JanuaryFebruary 1965).

"Raft River Geothermal Exploratory Hole No. 1 (RRGE-1). Completion Report," Report No. 100-10062 (NVO--410-30)

(October 1975).

Ratzle, M. L., and Simmons, G., "Microfractures in Rocks From Two Geothermal Areas," Geological Society of America Annual Meeting. (1975).

Roegiers, J. C., and Thill, R. E., "Rock Characterization at a Geothermal Site," 17th Utah University Rock Mechanics US Symposium Proceedings (1976).

Saba, J., and Szabo, J., "Some Remarks on Determining Deep Well Temperatures," Koolaj Foldgaz Volume 3, No. 1, (in Hungarian) (January 1970).

Sandbert, C. H., Thompson, G. A., and Wihite, D. E.; "Rocks, Structure, and Geologic History of Steamboat Springs Thermal Area, Washoe County, Nevada," US Geological Survey Professional Paper No. 458-B (1964). 
Sanyal, S. K., and Meidav, H. T., "Well Logging in the Geothermal Industry," 17th Annual SPWLA Logging Symposium Transactions (1976).

Scattolini, R., and Howell, F. L., "Preliminary Study of Heat Flow in Western North Dakota," EOS (American. Geophysical Union, Transactions), Volume 55, No. 5 (1974).

Schoeppel, R. J., "Use of Well Log Temperatures to Evaluate Regional Geothermal Gradients," Journal Petroleum Technology (1966).

Scott, H. D., "Measurement of Subsurface Formation Lithology, Including Composition and Fluids, Using Gamma Spectroscopy and Thermal Neutron Decay," Texaco, Inc. (December 1975).

Serra, 0., "Well Logs and Stratigraphy," Mem. Bur. Rech. Geol. Minieres No. 77, Part 2, 6 Pl. (in French) (1972).

Sestini, G., "Heat-Flow Measurement in Non-Homogeneous Terrains: Its Application to Geothermal Areas," Geothermics (February 1970).

Shabanov, S. F., and Tsaturyants, A. B., "The Problem of Convection in Wells, as Related to Geothermal Studies," Dokl Akad Nauk Azerbaidzh SSR Volume 22, No. 9 (in Russian) (1966).

Sigvaldason, G. E., and White, D. E., "Hydrothermal Alteration in Drill Holes GS-5 and GS-7, Steamboat Springs, Nevada," US Geological Survey (1962).

Sigvaldason, G. E., and White, D. E., "Hydrothermal Alteration of Rocks in Two Drill Holes at Steamboat Springs, Washoe County, Nevada," US Geological Survey Professional Paper 424-D (1961).

Simmons, G., and Nur, A., "Granites Relation of Properties In Situ to Laboratory Measurements," Science, Volume 162, No. 3855 (November 15, 1968).

Snyder, R. P., "Electric and Caliper Logs As Lithologic Indicators in Volcanic Rocks, Nevada Test Site," The Geological Society of America, Memoir 110 (1968).

Somerton, W. H., "Deformation Moduli of Water-Bearing Formations at Elevated Temperatures. Technical Completion Report," California University, Berkeley, California (January 1974).

Somerton, W. H., El-Shaarant, A. H., and Mobarak, S. M., "High Temperature Behavior of Rocks Associated with Geothermal Type Reservoirs," 44th Annual Society of Petroleum Engineers of AIME California Regular Meeting, Preprint No. SPE-4897 (1974). 
Summers, W. K., "Approximation of Thermal Gradient in Southeastern New Mexico Using Bottom-Hole Temperatures From Electric Logs," American Association Petroleum Geologists Bulletin, Volume 56, No. 10 (October 1972).

Takaki, S., and Tanaka, S., "Electrical Logging and Temperature Surveys at Matsukawa Geothermal Wells," Japanese Geological Survey Bulletin, Volume 19, No. 8 (in Japanese) (1968).

Tanner, W. F., "Geothermal Exploration from Deep-Well Data," 26 th Annual Gulf Coast Association Geological Society Meeting Transactions, Volume 26 (1976).

West, F. G., Kintzinger, P. R. and Laughlin, A. W., "Geophysical Logging in Los Alamos Scientific Laboratory Geothermal Test Hole No. 2," Los Alamos Scientific Laboratory Report No. LA-6112-MS (November 1975).

West, F. G., and Laughlin, A. W., "Spectral Gamma Logging in Crystalline Basement Rocks," Geology, Volume 4, No. 10 (October 1976).

Yakubov, A. A., Kharitonuv, M. F., and Maiveyer, Ye. I., "Methods of Analyzing Borehole Temperature Surveys (Exemplified by Investigations of the Geothermy of the Artema Island and Gyurgyany-Mure Fields), Izv. Vyssh. Ucheb. Zaved., Neft Gaz (1962).

Zemanek, J., "Formation Evaluation by Inspection With the Borehole Televiewer," Geophysics (April 1970).

Zohdy, A. A. R., Anderson, L. A., and Muffler, I. J. P., "Resistivity Self-Potential, and Induced-Polarization Surveys of a Vapor-Dominated Geothermal System," Geophysics, Volume 38, No. 6 (1973). 
NOTES 
The log analysis, as presented for the GT-2 and RRGE \#2 wells, is typical for the state-of-the-art techniques developed within the petroleum industry. Additional processing, particularly z-plot techniques, extend the ability to resolve lithology definition. For example: spectral gamma-ray data such as the concentrations of potassium, thorium or uranium, or thorium-uranium ratios have been used in $\mathrm{Z}$-plots of the GT-2 well and provided mineralogic trends for syenogranite, monzogranite, biotite, and hornblende (Merkel, 1976). The basic techniques and concepts in use currently can be used for much of the evaluation if a great deal of matrix and log response characteristics are collected and cataloged. The data from tests such as the LASL Hot DrY Rock Project and the Raft River Project are steps in this direction, as reasonably complete logging suites, sample and core data, and production-testing results are available.

The fundamental problems associated with geothermal well log interpretation can be divided into three groups.

1. Lithology and porosity

2. Fracture detection

3. Thermal evaluation

With improved solutions to these fundamental problems, other formation parameters, such as permeability, may be resolved with greater accuracy.

Efforts therefore should be directed to

1. Establishment of matrix and response characteristics for currently available logging tools. In addition, new tools such as the EMP (Electromagnetic 
Propagation Tool) should be evaluated for their potential contribution to solving the problems.

2. Evaluate the many techniques for fracture detection and define the best systems of interpretation for application to geothermal wells.

3. Refine the techniques used for determining true reservoir temperature and the heat flow characteristics of formations with various pore structures. 
B. Gectherma1 Test Hole GT-2

The Geothermal Test Hole No. 2 (GT-2) is drilled into Precambrian-age basement granitic rocks of the Jemez Mountains in north-central New Mexico. Drilled by Los Alamos Scientific Laboratory, the nell tests the viability of heat extraction by the Hot Dry Rock (HDR) technique (See references, page 112).

The interval selected for study, $1905-2027 \mathrm{~m}$ (6 250 - $6650 \mathrm{ft}$ ) is described (Pettitt, 1975; Kintzinger and others, 1977) as predominantly light pink granite and small sections of

Schist; gray with biotite

Gneiss; white with quartz, feldspar

Granite; pink, slightly altered

Granodiorite; pink

Quartz Monzonite; light pink.

Electrical logging for this interval was performed by Schlumberger Well services and included

1. Dual Induction - Laterolog

2. Compensated Neutron - Formation Density with Gamma Ray and caliper

3. Borehole Compensated Sonic.

In addition, other surveys were performed by Birdwell, Dresser-Atlas and Go Wireline Services over the same depth interval and other portions of the borehole (see listing of logs, Task 3, page 61).

Initial processing of the data by computer was performed in order to determine

1. Lithology

2. Porosity

3. Fracture locations. 
Figures 4.1, 4.2, and 4.3 display the neutron, density, and sonic log data in crossplot form (Schlumberger, 1972).

Figure 4.1 is a crossplot of density and neutron values showing the frequency of occurrence of paired values. The area with the greatest frequency of occurrence is blocked in to indicate the trend of data. For reference, the response lines for sandstone (quartz), limestone, and dolomite are shown. The trend indicates that the matrix may be a mixture of quartz and some mineral with a matrix density less than $2.65 \mathrm{~g} / \mathrm{cm}^{3}$, and very low porosity.

Figure 4.2 is a frequency crossplot of neutron and sonic data. The trend is ketween the reference sandstone and limestone response lines. If a reference sandstone response line is drawn using a matrix velocity of $5.94 \mathrm{~km} / \mathrm{s}$. (19 $500 \mathrm{ft} / \mathrm{s}$ ) shown as dotted line, instead of $5.49 \mathrm{~km} / \mathrm{s}$ (18 $000 \mathrm{ft} / \mathrm{s}$ ) as shown with solid line, the data indicate most rock to have acoustical matrix values higher than quartz sandstone.

Figure 4.3 crossplots density and sonic data. This particular crossplot has very poor porosity and lithology resol.ution in the regions of sandstone, limestone, and dolomite. It is kest suited for indications of evaporite minerals (Schlumberger, 1972). If the sandstone response line was adjusted to a matrix velocity of $5.94 \mathrm{~km} / \mathrm{s}$ (19 $500 \mathrm{ft} / \mathrm{s}$ ) the sandstone and limestone response lines would nearly coincide, but with different porosity values. The trend of data indicates the rock to be lower in density and/or sonic travel times to be much shorter than the quartz sandstone trend. Since the section studied is predominantly light pink granite, the low density and low travel time may be caused by the presence of orthoclase (matrix density of $2.52 \mathrm{~g} / \mathrm{cm}^{3}$ and plagioclase (travel time $=164 \mu \mathrm{s} / \mathrm{m}(50 \mu \mathrm{s} / \mathrm{ft})$ ) feldspar respectively. 
Figure 4.4 is a crossplot of $M$ and $N$ values (Schlumberger, 1972, and Appendix A). This plot combines the responses cf sonic, neutron, and density logs. The trend of data indicates a fluid/matrix combination lighter than water-filled sandstone or limestone. Fracturing may also be present.

POROSITY - LITHOLOGY MODEL

Considering the data trends, a two-mineral model was selected for porosity determination and as an indicator cf lithology. The matrix values for this mineral pair are

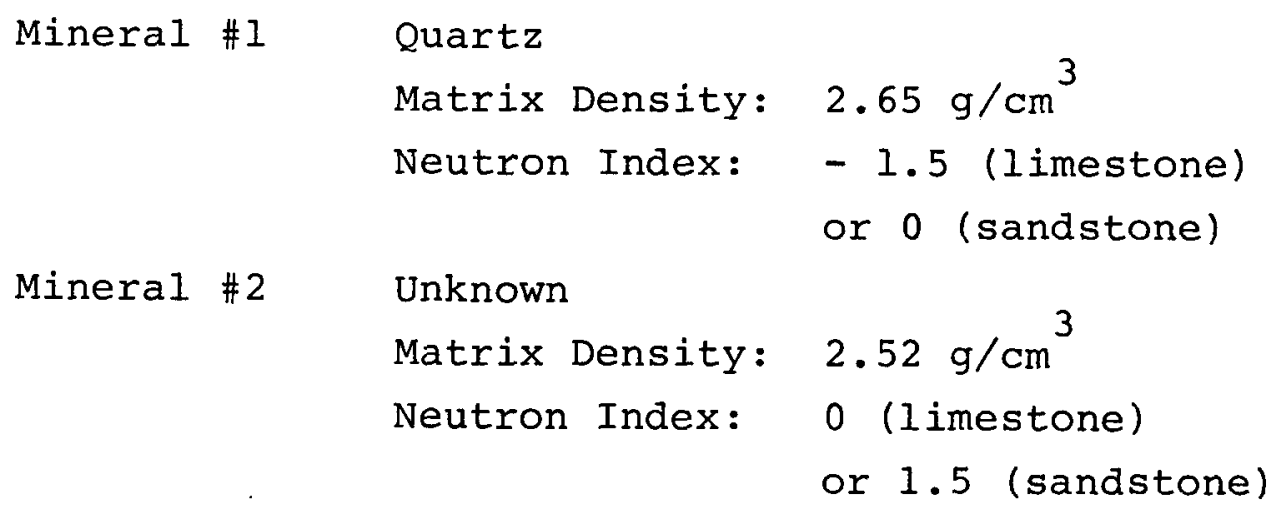

Tliese ralues are shown on Fj.gure 4.1 with Mineral \#2 noted with a triangular symbol. Figure 4.5 is a chart of the model. The neutron values are converted to sandstone units for a linear response. This model allows the computation of porosity and an apparent matrix density. The dashed lines are the equal-porosity lines between the two minerals. The apparent matrix density is a linear interpolation between $2.65 \mathrm{~g} / \mathrm{cm}^{3}$ for sandstone and $2.52 \mathrm{~g} / \mathrm{cm}^{3}$ for Mineral \#2. 
APPLICATION OF SONIC DATA

Inspection of the sonic data (Figures $4.2,4.3$, and 4.4) indicates the possibility of fracturing. To check this possibility, an apparent matrix travel time ( $t_{\mathrm{ma}}$ ) a was computed by setting the sonic porosity equal to the porosity computed from the two-mineral model. If fracturing is causing the recorded sonic travel time to read too low, the $\left(t_{\mathrm{ma}}\right)$ a will also be lower than would be expected. Figure 4.6 is a frequency crossplot of this ( $\left.t_{\mathrm{ma}}\right)$ a vs. ( $\left.\rho_{\mathrm{ma}}\right) \mathrm{a}$. This plot also aids in selecting the sonic matrix values for the two minerals. The data trend shows an increasing value of $\left(t_{m a}\right)$ a with lower $\left(\rho_{m a}\right) a$ (Lines $A$ and $\left.B\right)$. Note that both scales are very expanded which results in a wider data spread than on the previous crossplots with normal scaling.

If the recorded sonic $\log$ is responding according to the classical description of fracture effects, quantity of fracturing will increase in a direction indicated by Line $c$.

To check this possibility, a computer program was run to indicate the zones with the greatest likelihood for fractures to occur. (Further discussion of this technique is covered in Task 5 and 6C.) The output of this program is a term "FRAC" which increases in value with increasing indications of fracturing. Figure 4.7 is the same crossplot as Figure 4.6 with the values of FRAC (a range of 1 to 5) printed in place of the frequency of occurrence. For clarity, the FRAC values of 1,4 , and 5 are outlined. The trend indicates less fracturing with higher sonic reading and higher grain density. The greatest amount is associated with the rock of lowest grain density. 


\section{DISCUSSION OF INTERPRETATION TECHNIQUE}

The two-mineral technique of porosity and lithology interpretation using bulk density and neutron is a commonly used method in cases when the rock characteristics are well known or when one or more of the rock types may be unknown. Advantages of this technique are

1. Simplicity. The technique is easily adaptable to computer processing or manual interpretation via crossplets.

2. Unknown rock types or parameters. In most cases, the matrix values may be determined from crossplots.

3. Porosity determination. The porosity, as determined by this method, is normally very close to true porosity.

4. Lithology determination. The apparent grain density can be used to indicate the rock type or mixtures of two-rock types.

Any petrophysical model has limitations as to the type of formation which may be evaluated.

1. Additional Minerals. Depending on the matrix characteristics and the types of lithology mixtures, it may be possible to build adjoining twomineral models. If, however, three minerals are mixed together, it is not possible to sort out the lithology without additional data input. Addition of the sonic data may be used to determine lithology of three minerals under the following conditions.

A. The matrix parameters are different enough to allow resolution of the data.

B. The logs are responding only to lithology and primary porosity. For example, the sonic log 
cannot be influenced by fractures or vugs or mechanical properties of the formation.

2. Utilizing resistivity data. Resistivity data may be used to estimate porosity if additional parameters are known.

A. Resistivity of formation water at formation temperature $\left(R_{w}\right)$.

B. a and $m$ for relationship of formation factor $\left(F=a / \phi^{m}\right)$. These factors may change with the lithology and pore geometry. Also, resistivities may be influenced by anisotropic characteristics of the rock.

Sample description and cores already identified the type of rock expected. Even then, it was necessary to select matrix parameters from the crossplots. Since granite may have a very wide range of matrix parameters (matrix density 2.45 to $2.94 \mathrm{~g} / \mathrm{cm}^{3}$ and matrix travel time 42.6 to $76.3 \mu \mathrm{s} / \mathrm{ft})$, it is not feasible to determine from the logs alone if the data grouped along the quartz matrix line, or the data selected as Mineral \#2 is the granite. Notwithstanding the unknowns, the matrix parameters fell in the ranges expected for the type of rock which leads to reasonable porosity values. Verification was made for the detection of fracturing by the classical definition of effects on the sonic $\log$.

The analog playback (Figure 4.16) enclosed is the result of the described two-mineral model interpretation technique.

RAFT RIVER GEOTHERMAL RESERVOIR

The Raft River Geothermal Reservoir is located in south-central Idaho, Cassia County. The upper $1402 \mathrm{~m}$ (4 600 
ft) is primarily tuffaceous siltstone, conglomerate, and sandstone. Below this sequence, a metamorphic zone of phyllite, schist, and quartzite rests on the quartz monzonite basement rock. The water production from Raft River Reservoir is dependent on highly fractured zones (Stoker and others).

A 530m (1 740-ft) interval was selected for study of lithology definition. Porosity and $\mathrm{M}-\mathrm{N}$ crossplots are made for two zones from the RRGE \#2 well.

I $658-1422 \mathrm{~m}$ (5 $440-4665 \mathrm{ft}$ ): Schist, quartzite, etc. (Figs. $4.8-4.11$ ).

$1422-1295 \mathrm{~m}(4665-4250 \mathrm{ft})$ : Tuffaceous siltstone, etc. (Figs. 4.12-4.15).

The crossplots of the deeper interval fall into three groups.

Group 1: Quartz Monzonite and Quartzite. The porosity data plots primarily between the classical matrix lines of sandstone and limestone. Distinction between the two can be made by two characteristics. The quartz monzonite ( $1524 \mathrm{~m}$ (5 $000 \mathrm{ft.}$ ) and deeper - see enclosed logs) is predominantly less dense than the quartzite as reflected by the density log. The neutron log, however, shows both types of rocks to have very little porosity or associated water or hydrogen. Another distinctive characteristic is the Gamma Ray. The quartz monzonite is very radioactive as compared to the quartzite. In fact, so radioactive that the gamma-ray detector was saturated or recording limits reached for most of the interval.

Group 2: Mica Schist. The location of mica schist on the three-porosity crossplots is an example of how only twoporosity logs can be misleading in lithology interpretation (1423 - $1442 \mathrm{~m}(4670-4730 \mathrm{ft}$ ) on logs). 
Density-Neutron crossplot:

Data plots between limestone and dolomite.

Sonic-Neutron crossplot:

Data plots ketween sandstone and limestone.

Density-Sonic crossplot:

Data appears more dense than dolomite or with a larger transit time.

The mica schist is more dense than the quartzite or quartz monzonite, but with a higher neutron hydrogen index.

Group 3: The interval $1734-1756 \mathrm{~m}(5690-5760 \mathrm{ft})$ is shown on the crossplots as having the highest density and the highest neutron hydrogen index. The transit time is around $164 \mu \mathrm{s} / \mathrm{m}(50 \mu \mathrm{s} / \mathrm{ft})$. The lithology of this zone has not been precisely identified, although correlation between wells is fairly straightforward. The porosity data plots in the same area as biotite. However, biotite is $8.7 \%$ potassium by weight and should reflect much more radioactivity than the 30 API units on the gamma ray log. Extensive hydrothermal alteration has occurred in the Raft River Reservoir and various transformations may have taken place.

A characteristic of the sonic log was noted on the heading by the Logging Engineer while monitoring the acoustical wave train on an oscilloscope. The compressional wave was greatly reduced and at times almost gone over the deepest section of well. The result of this can be seen as the erratic readings of the sonic as shown in the computer playback of digitized data. A second set of logging tools was tried with the same results. Such tool response would record the transit time of the compressional (P) wave, the shear (S) wave, or a value between the two. Additional data is needed to decisively determine the formation characteristics which would cause this particular tool response. 
The zone above $1422 \mathrm{~m}$ (4 665 ft) shows a wide range of porosity with most data points around the limestone line or between limestone and sandstone. The M-N crossplot, which eliminates the porosity variable and responds mostly to lithology, shows one dominant trend likely to occur with two minerals and their combinations. With the wide range of parameters possible for tuffaceous material, separation of lithology types will require additional information to identify the trends.

Porosity is computed using a standard three-mineral model, with classical values for sandstone, limestone, and dolomite. Two playbacks are enclosed for comparison to the crossplot data (Figures 4.17 and 4.18 ).

\section{REFERENCES}

Aamndt, R. Lee, "Hydraulic Fracture Experiments in GT-1 and GT-2," Los Alamos Scientific Laboratory report LA-6712

(February 1977).

Brookins, D. G., Forbes, R. B., Turner, D. L, Laughlin, A. W., and Naeser, C. W., "Rb-Sr, K-Ar, and Fission-Track Geochronological Studies of Samples from LASL Drill Holes GT-1, GT-2, and EE-1," Los Alamos Scientific Laboratory report LA-6829-MS (June 1977).

Heimlich, R. A., "Morphology of Zircons from Precambrian Rocks Penetrated by Geothermal Test Hole GT-2," Los Alamos Scientific Laboratory report LA-6433-MS (July 1976).

Kintzinger, P. R., West, F. G., and Aamodt, R. L., "Downhole Electrical Detection of Hydraulic Fractures in GT-2 and EE-1," Los Alamos Scientific Laboratory report LA-6890-MS (July 1977).

LASL HDR Project Staff, "Hot Dry Rock Geothermal Energy Development Project," Annual Report Fiscal Year 1977, Los Alamos Scientific Laboratory report LA-7109-PR (February 1978).

Merkel, R. H., Report for Los Alamos Scientific Laboratory (1976). 
Pettitt, Roland A., "Planning, Drilling, and Logging of Geothermal Test Hole GT-2, Phase I," LOS Alamos Scientific Laboratory report LA-5819-PR (January 1975).

Pettit, Roland A., "Testing, Drilling, and Logging of Geothermal Test Hole GT-2, Phase II," Los Alamos Scientific Laboratory report LA-5897-PR (March 1975).

Pettitt, Roland A., "Testing, Drilling, and Logging of Geothermal Test Hole GT-2, Phase III," Los Alamos Scientific Laboratory report LA-5965-PR (June 1975).

Schlumberger, "Log Interpretation - Volume I - Principles" (1972).

Stoker, R. C., Goldman, D., and Kunze, J. F., "Deducing Production zones From Well Logs," EG\&G Idaho, Inc.

West, F. G., Kintzinger, P. R., and Purtymun, W. D., "Hydrologic Testing Geothermal Test Hole No. 2," Los Alamos Scientific Laboratory report LA-6017-MS (July 1975). 


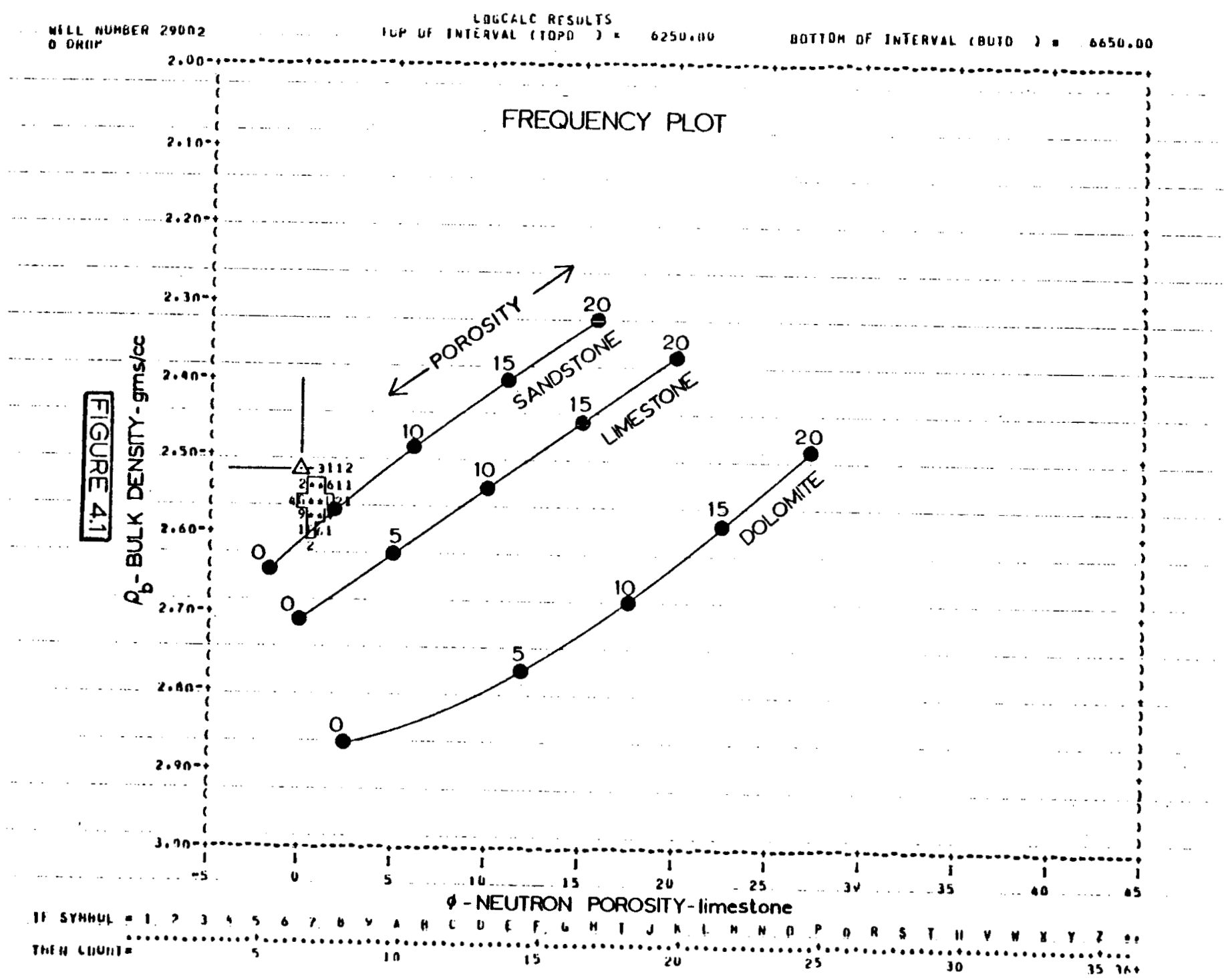




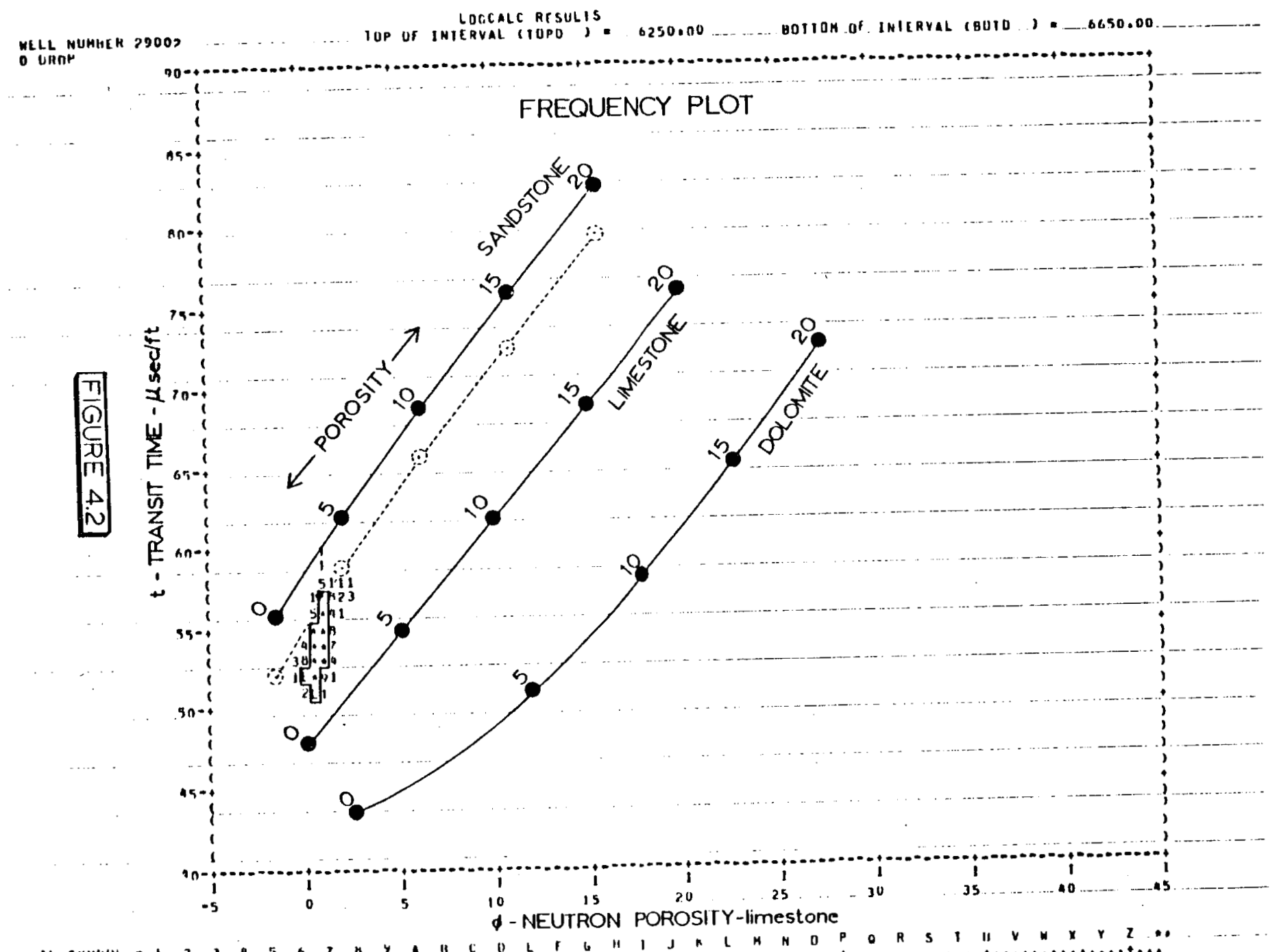

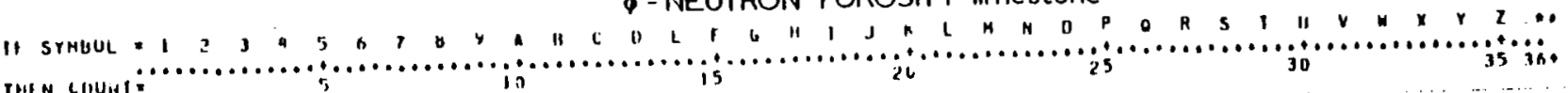




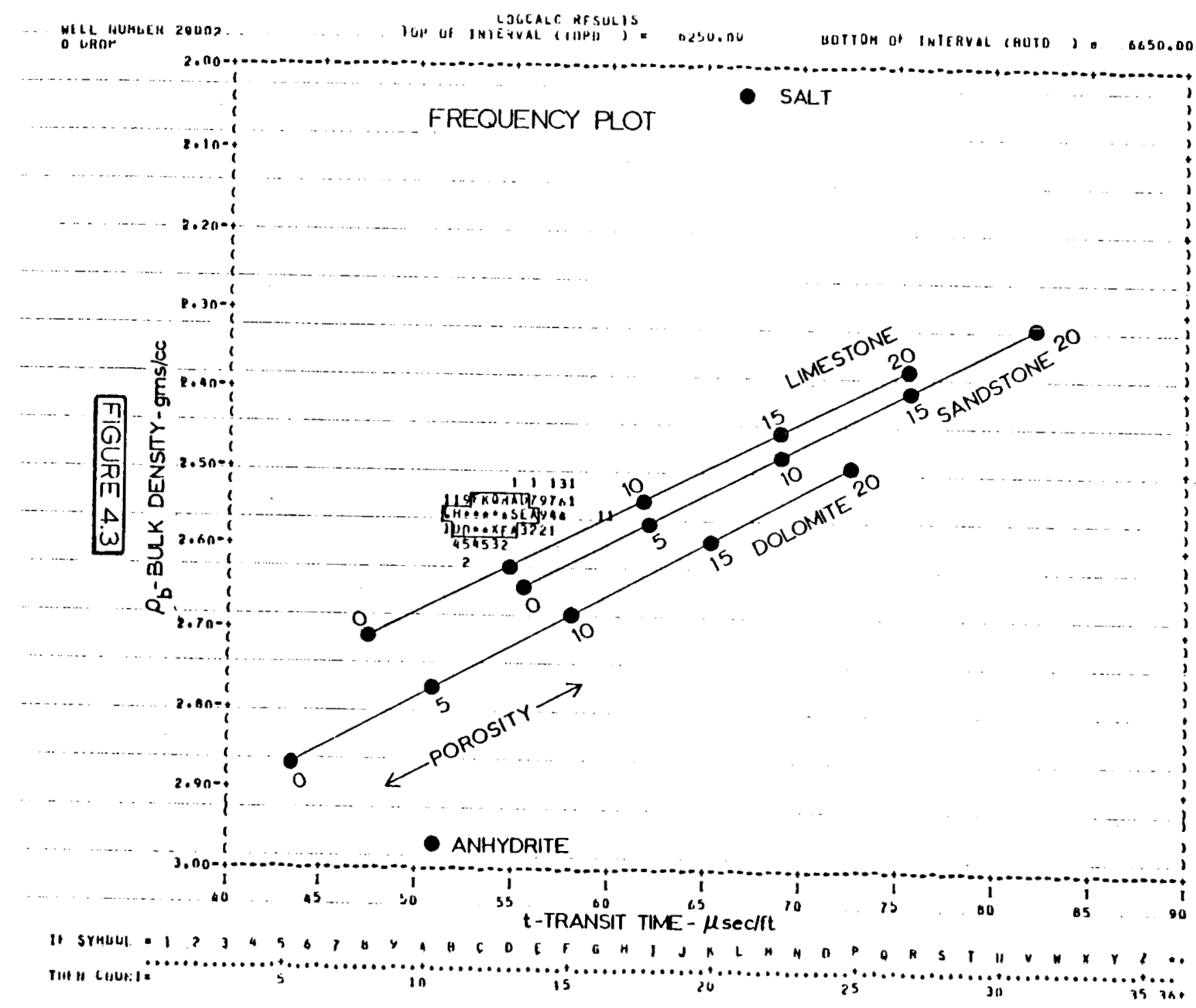




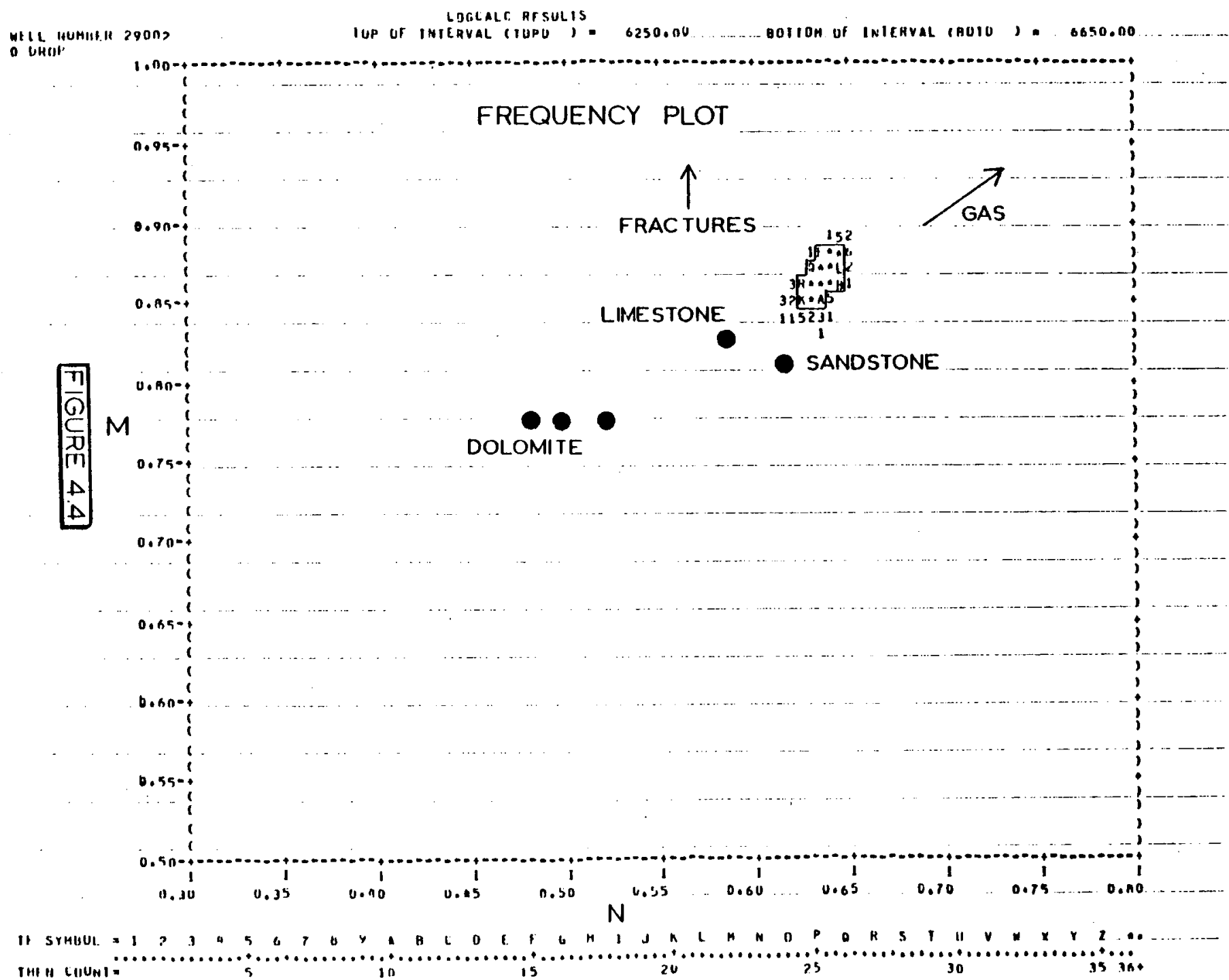




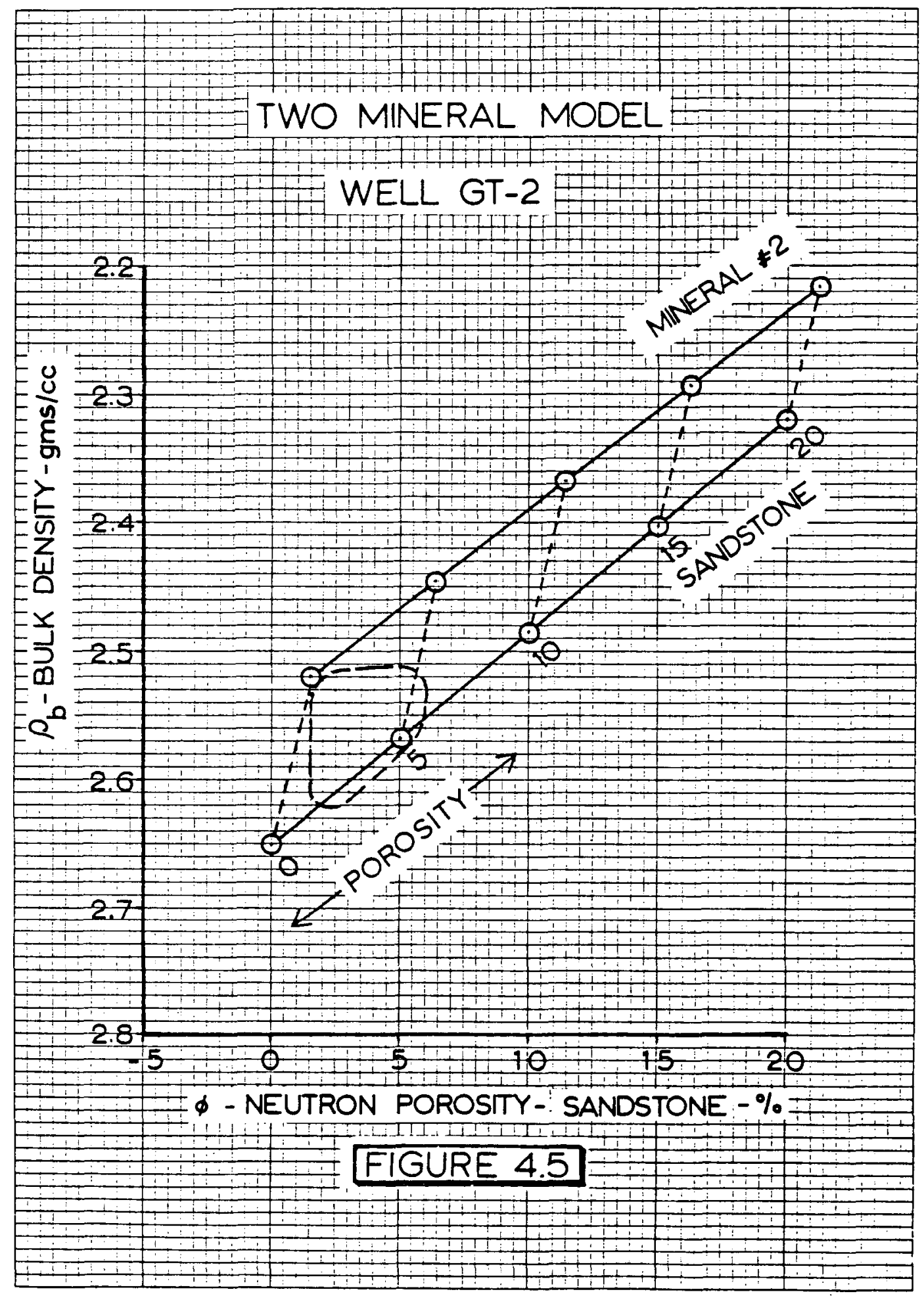




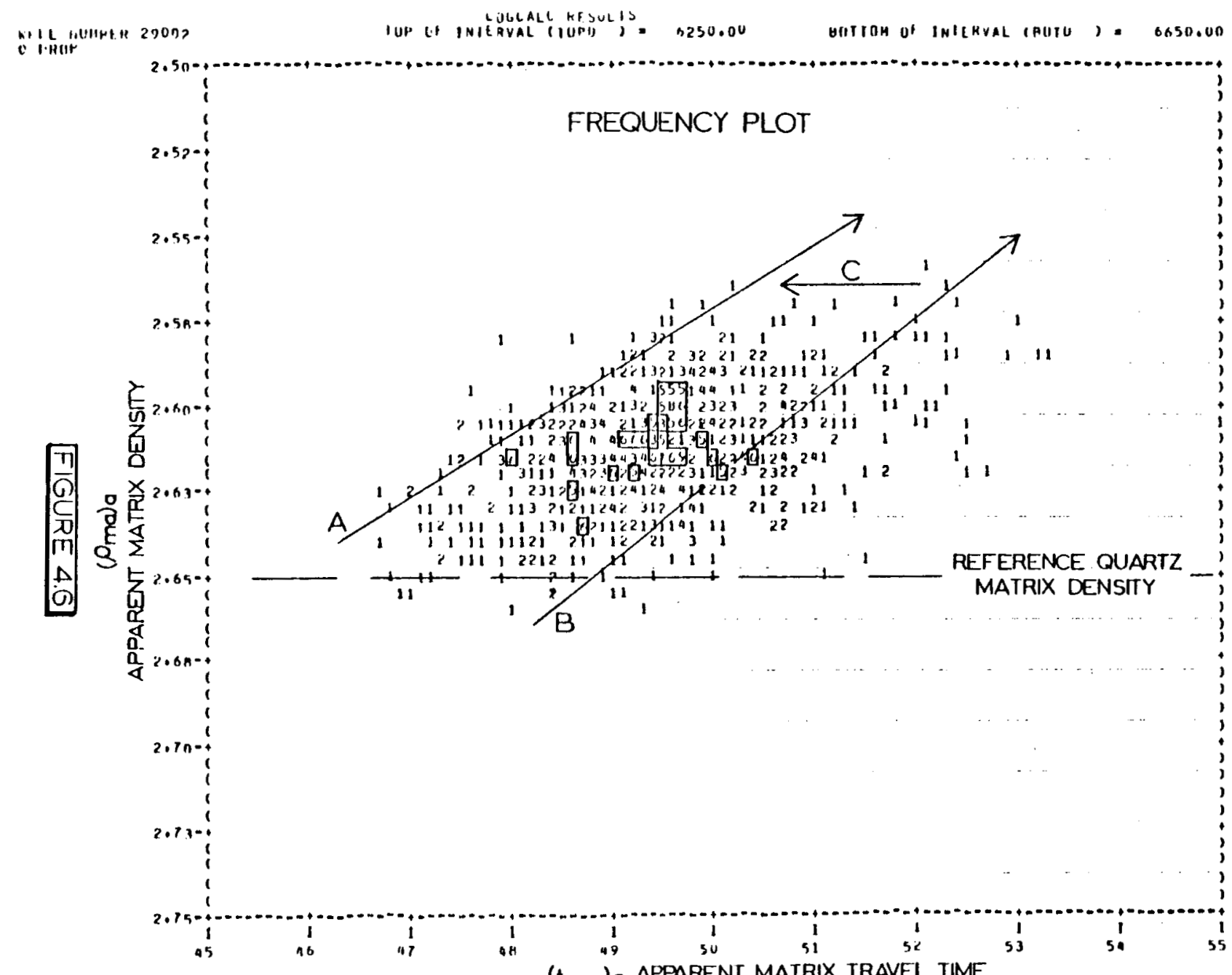

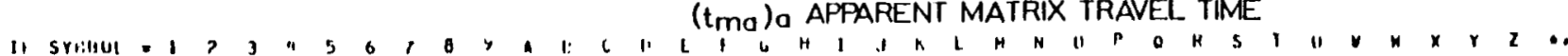

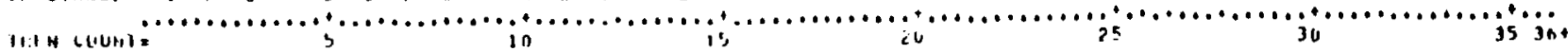




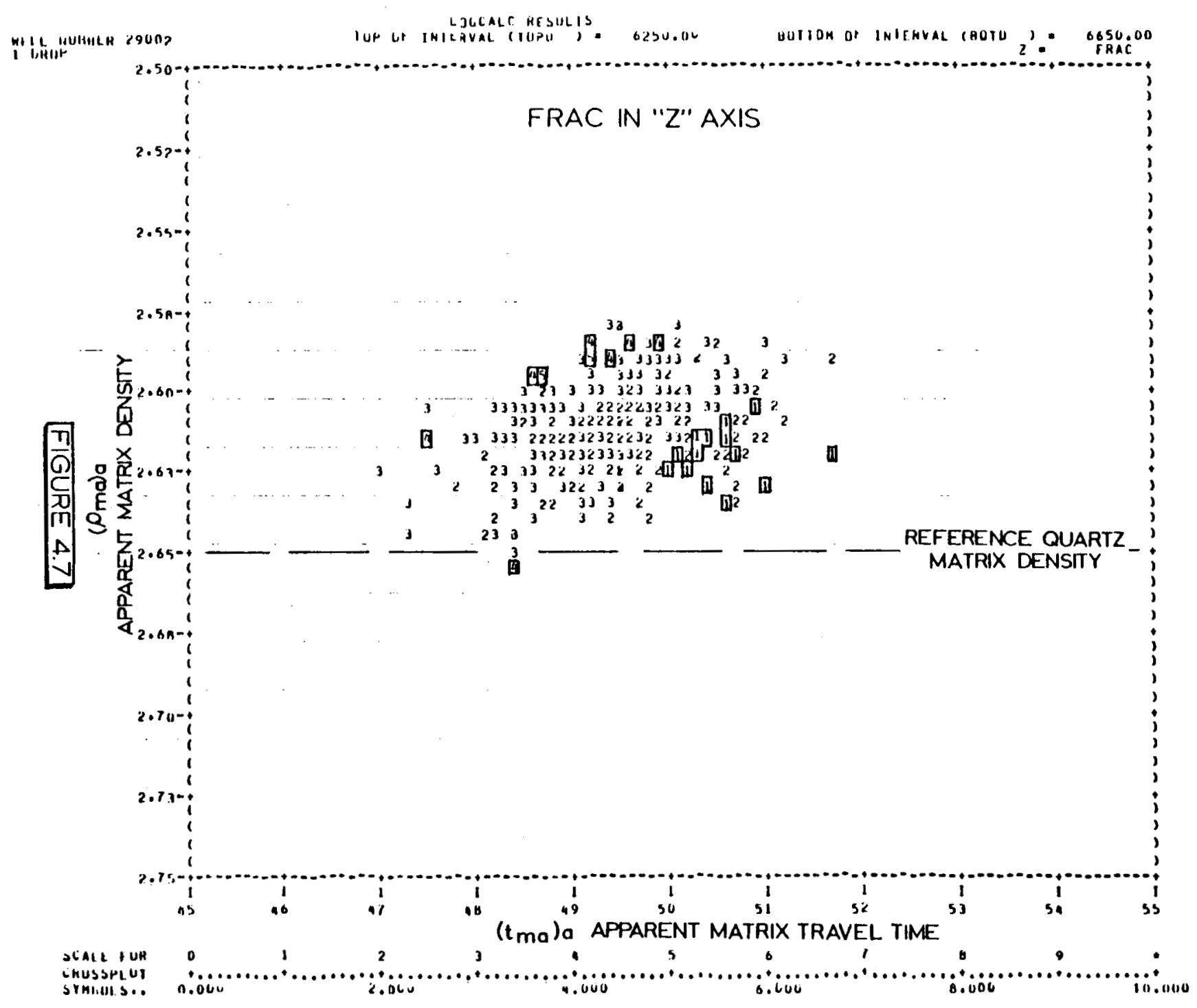




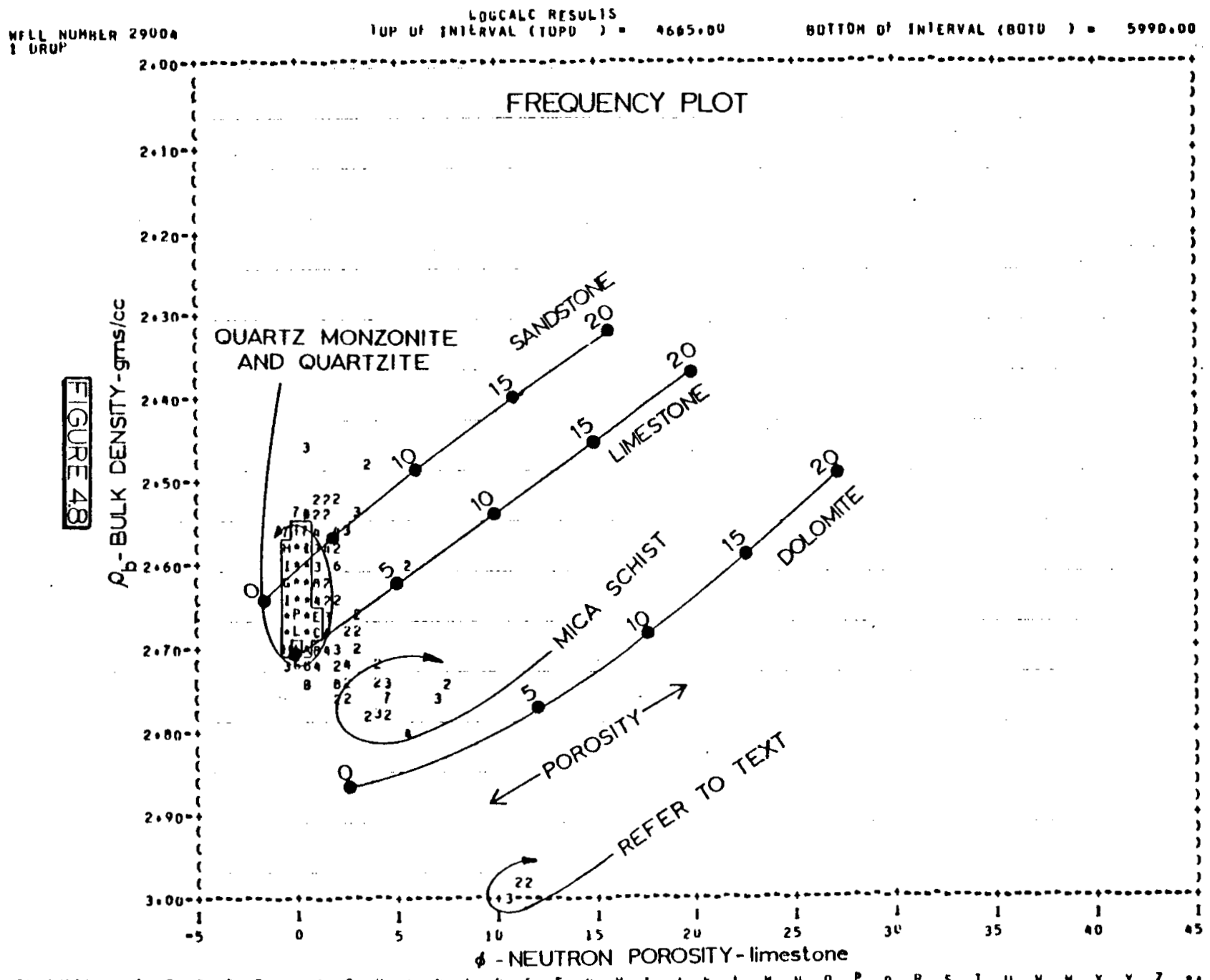

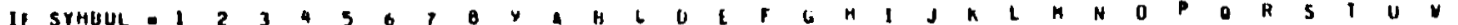

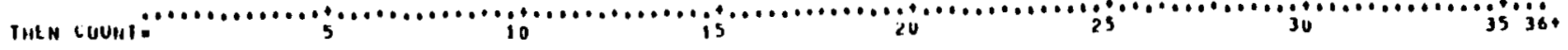




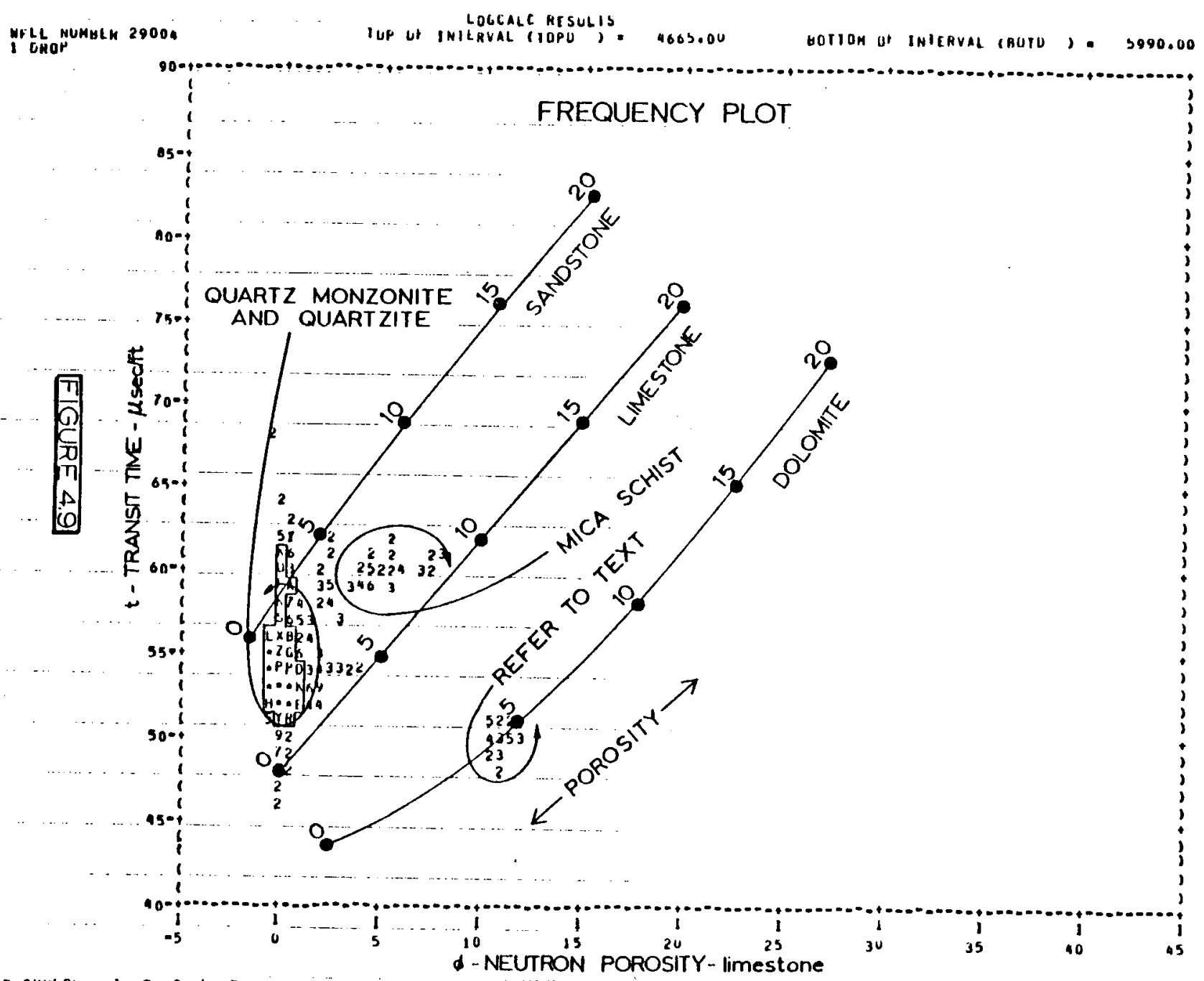

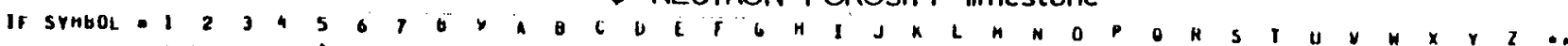

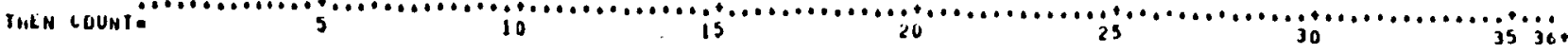




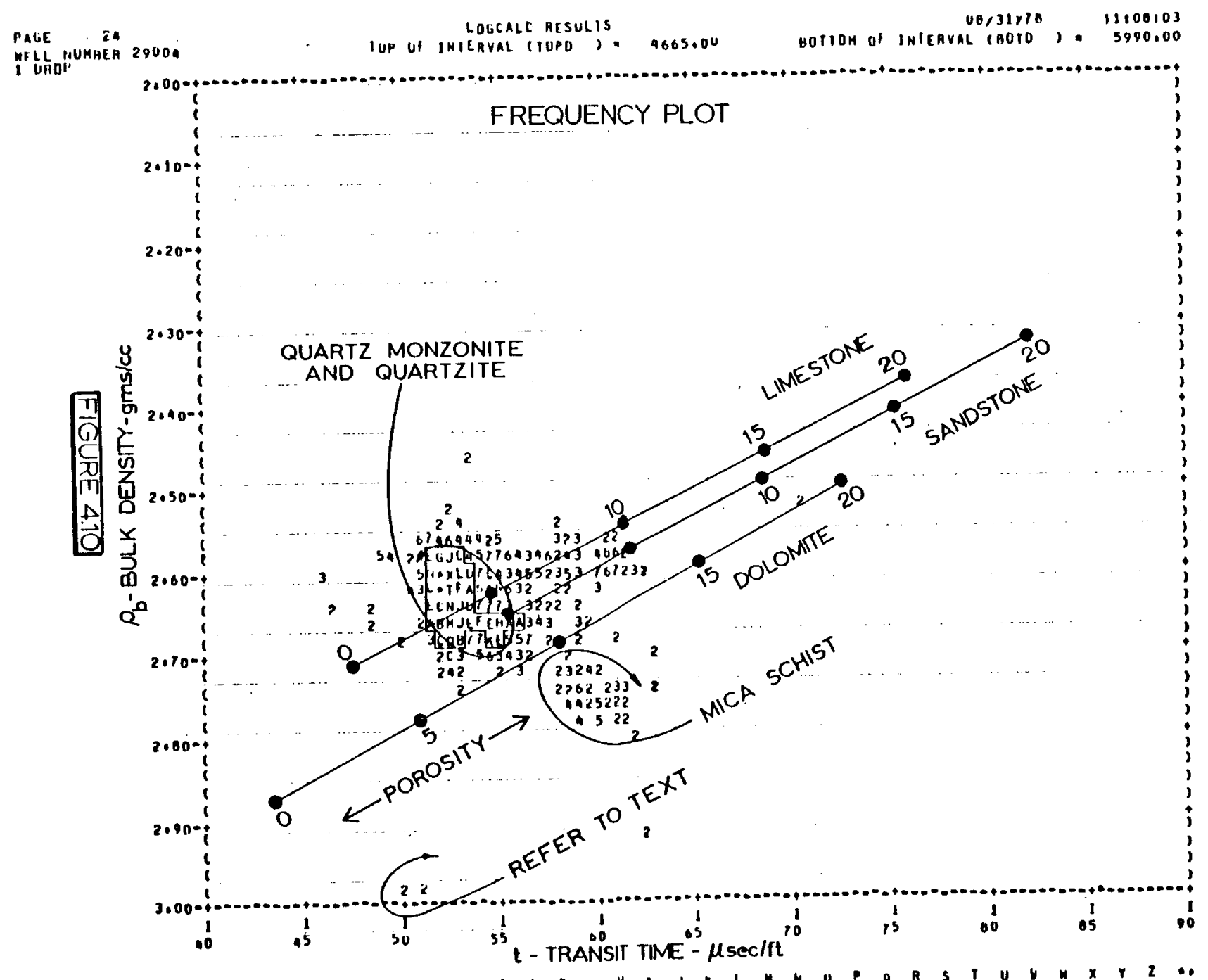

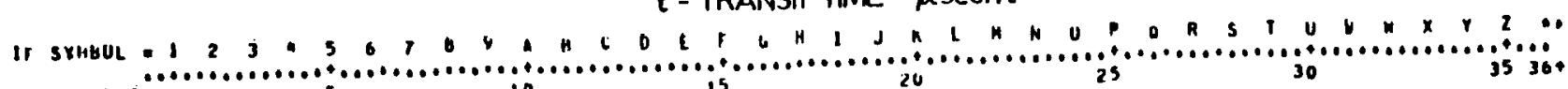
int.x counl: 


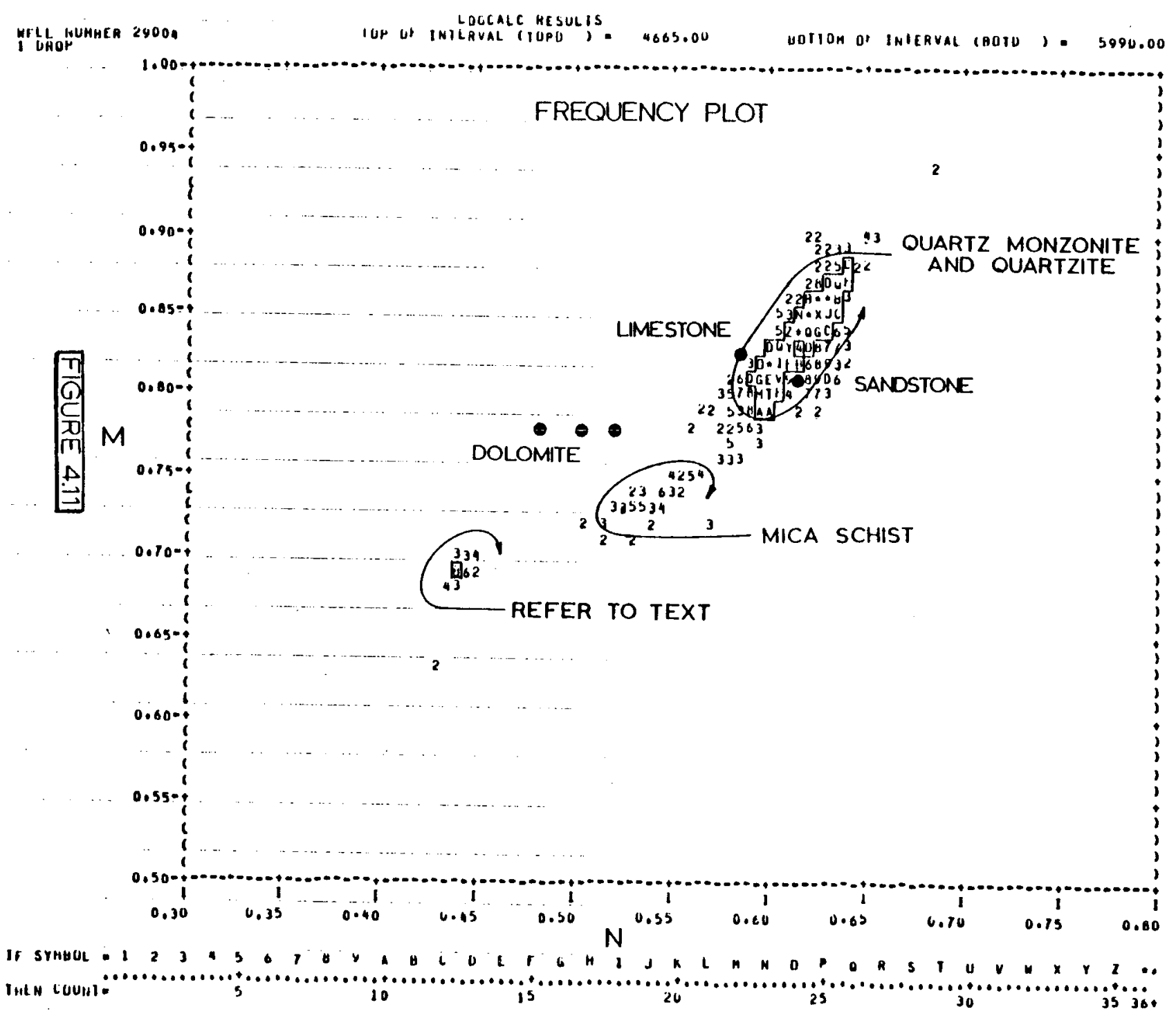




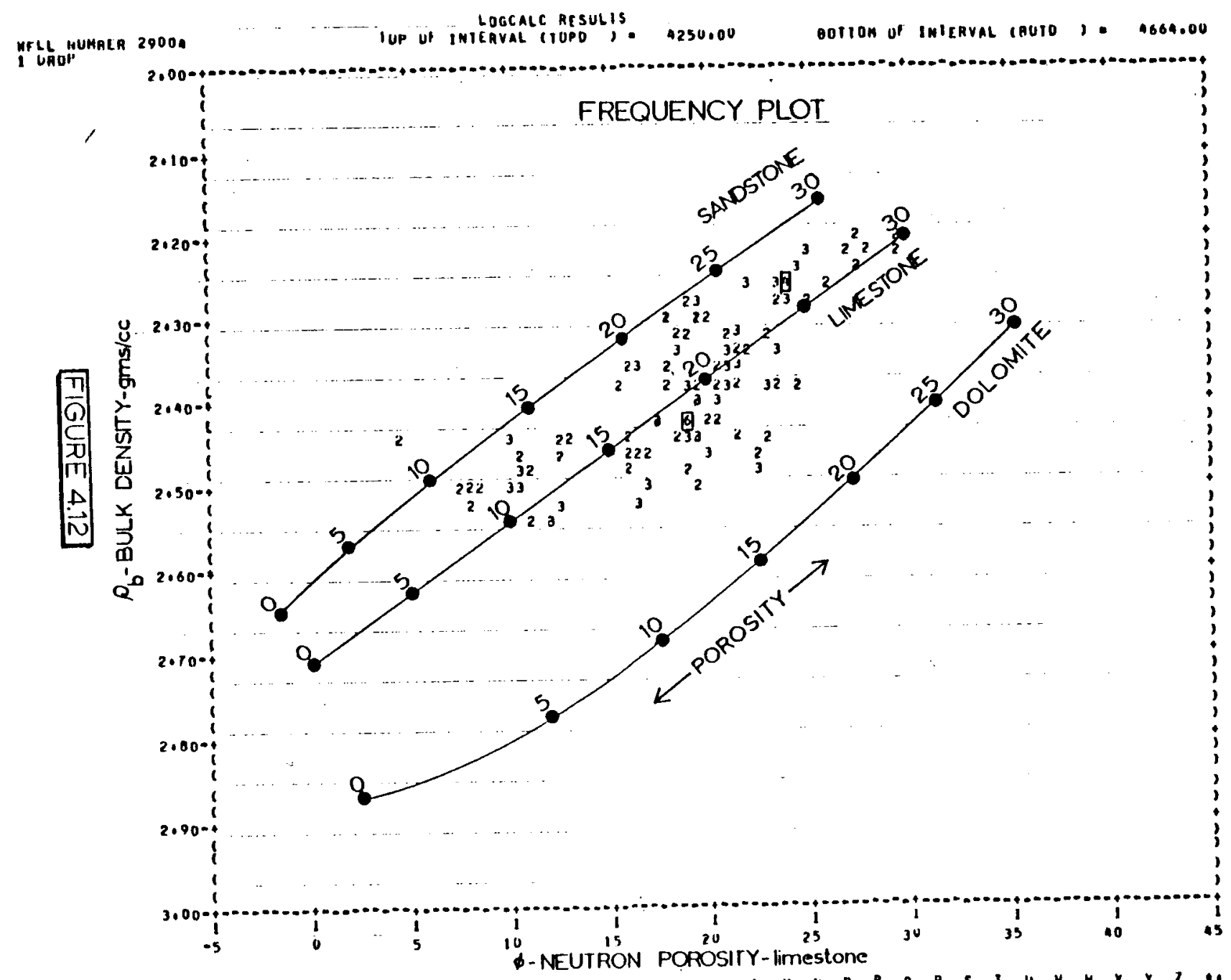

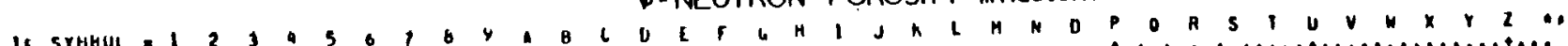

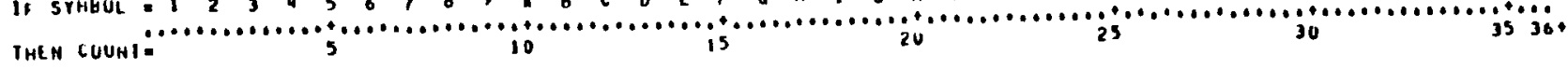




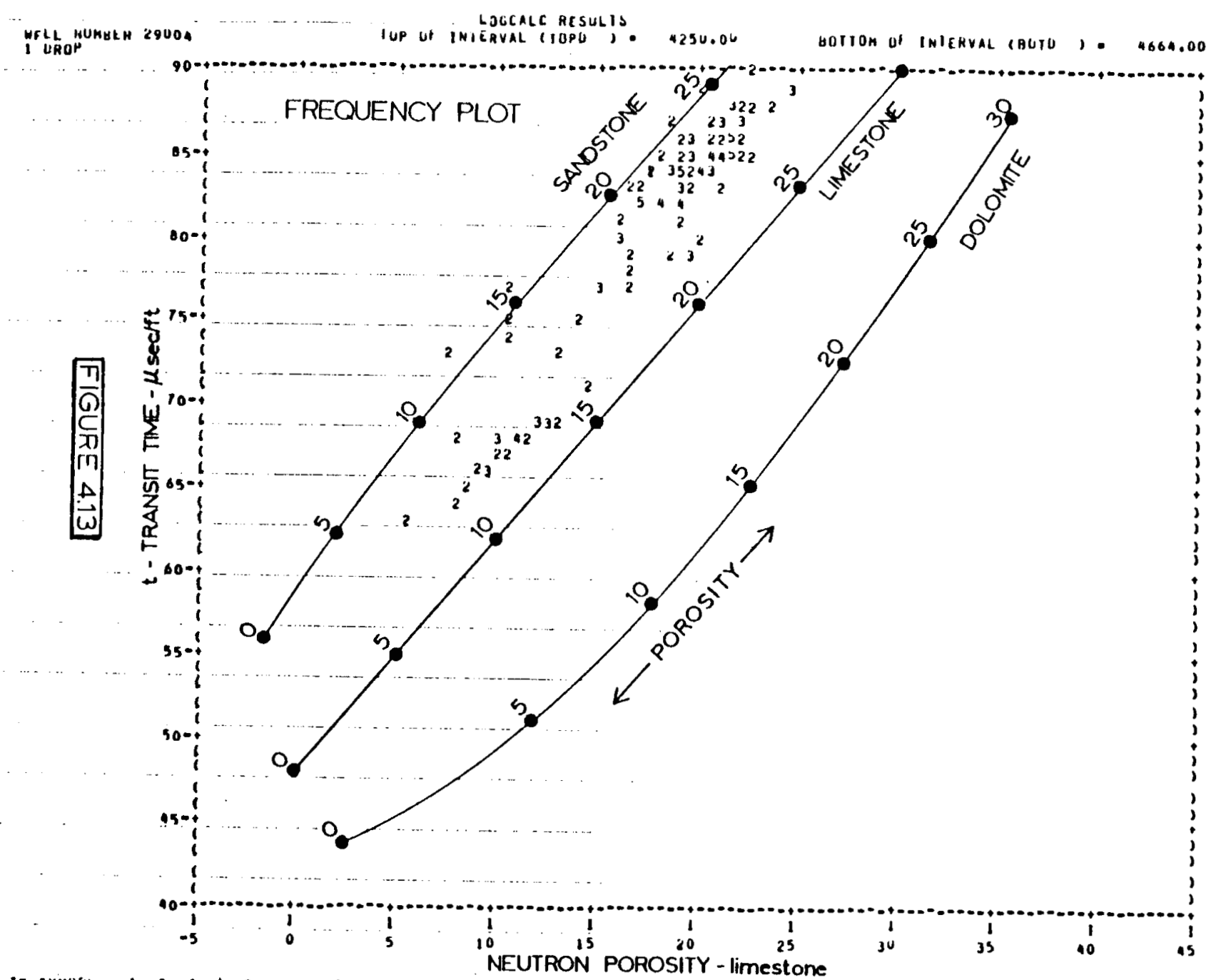

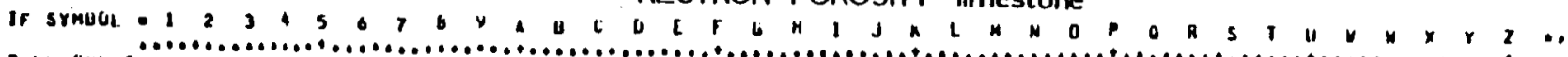

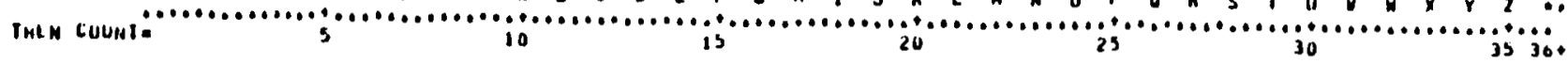




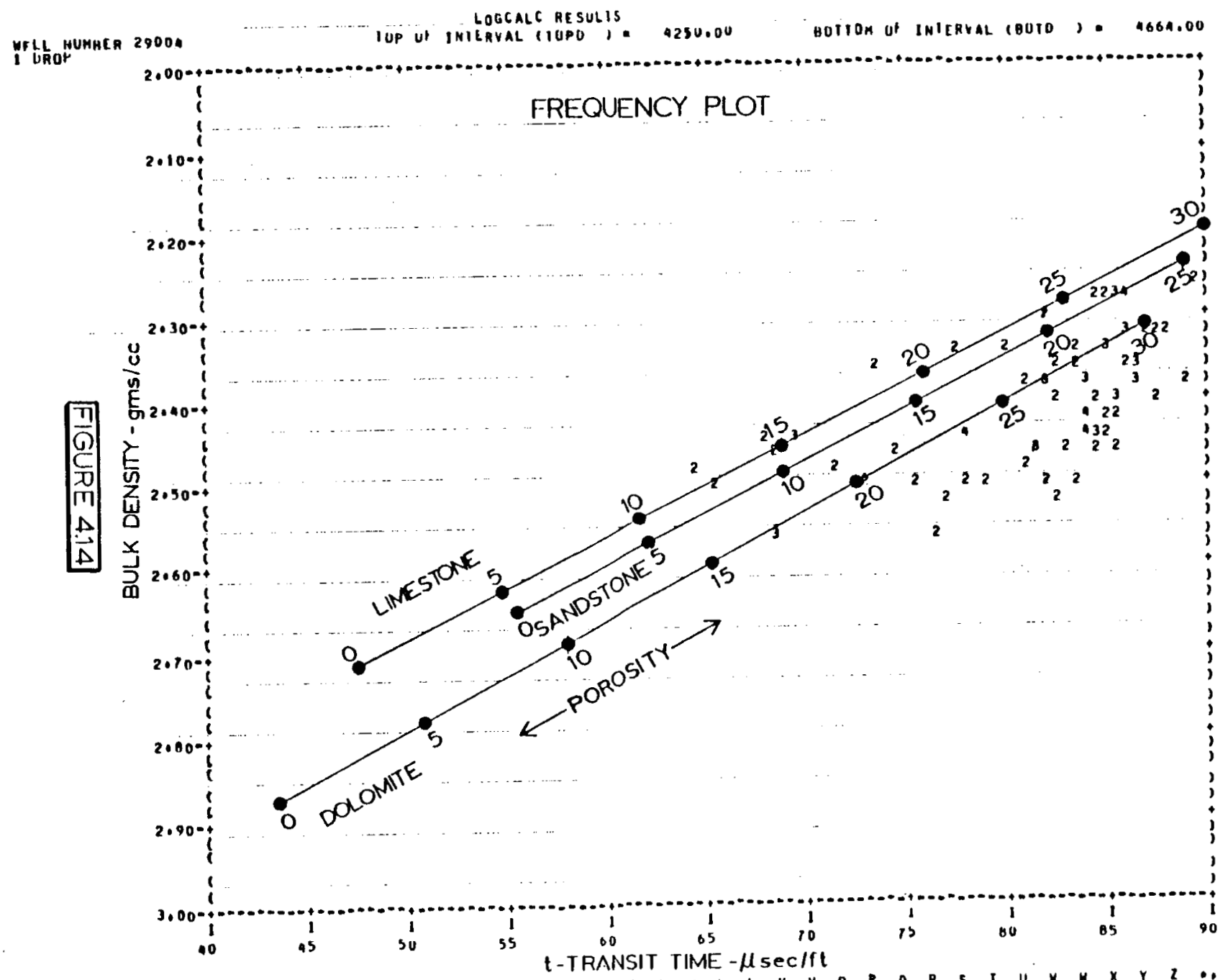

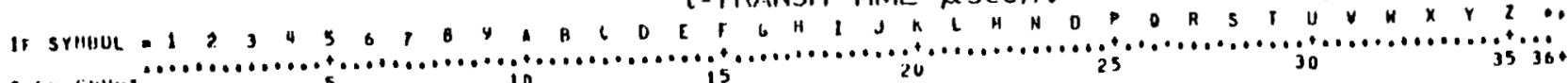
INEM CUUMT: 


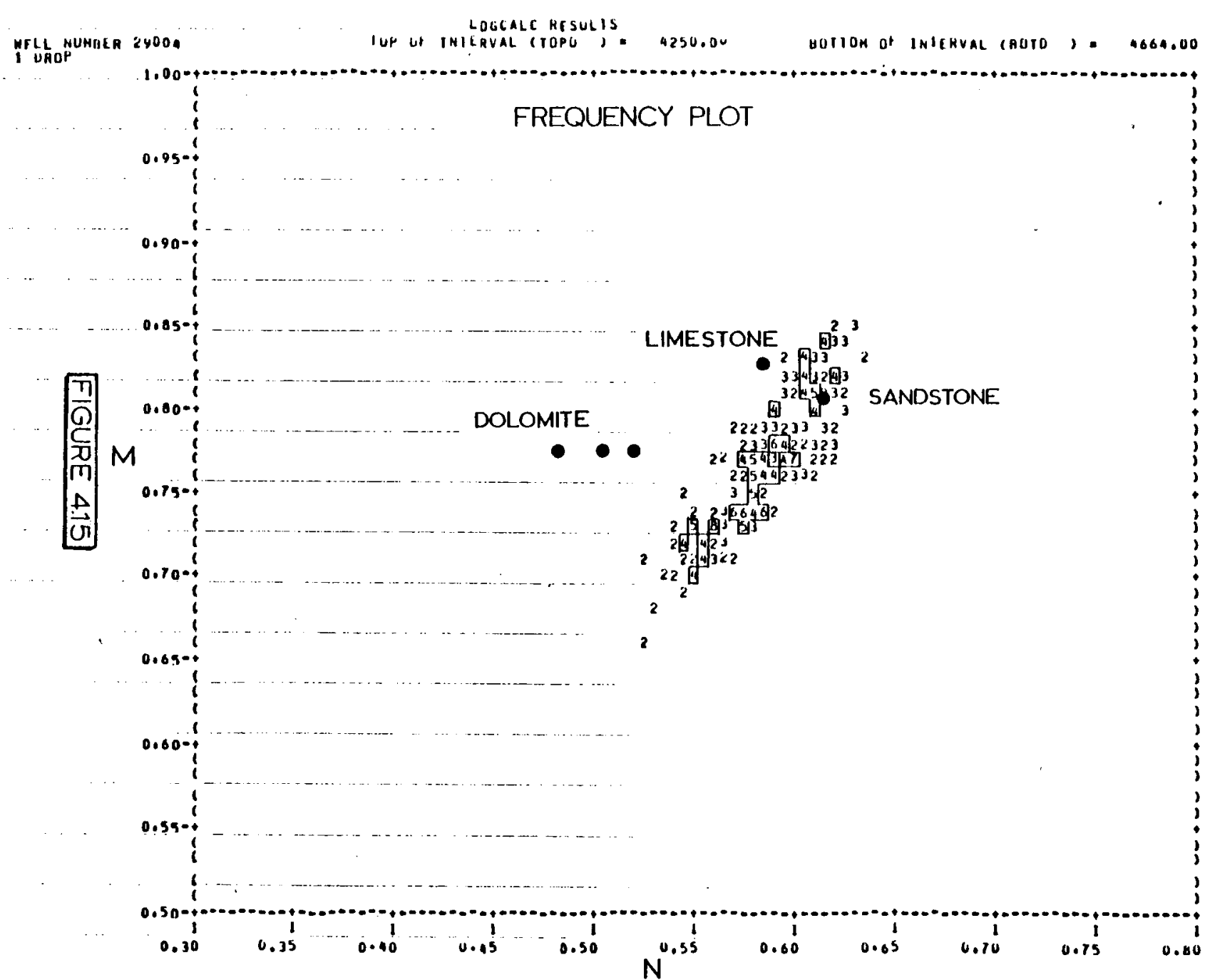

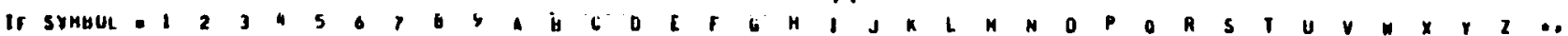


$\left[\begin{array}{l}\text { NOTES } \\ \text { N. }\end{array}\right.$

126

7

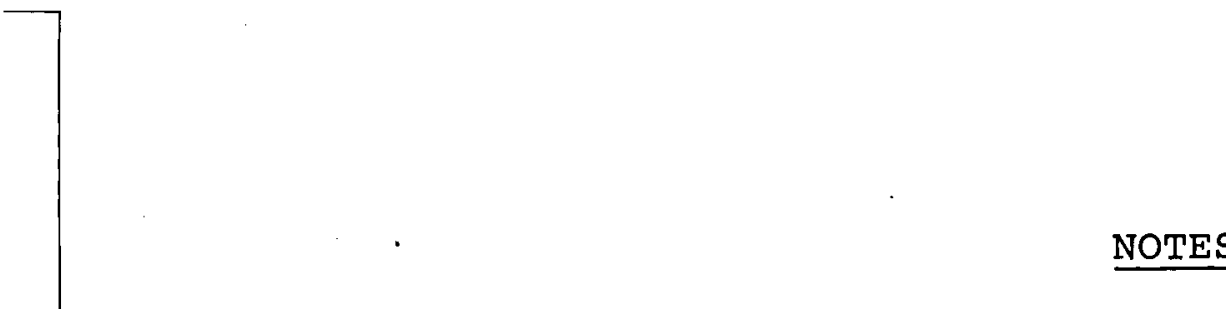

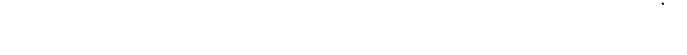

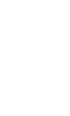

126
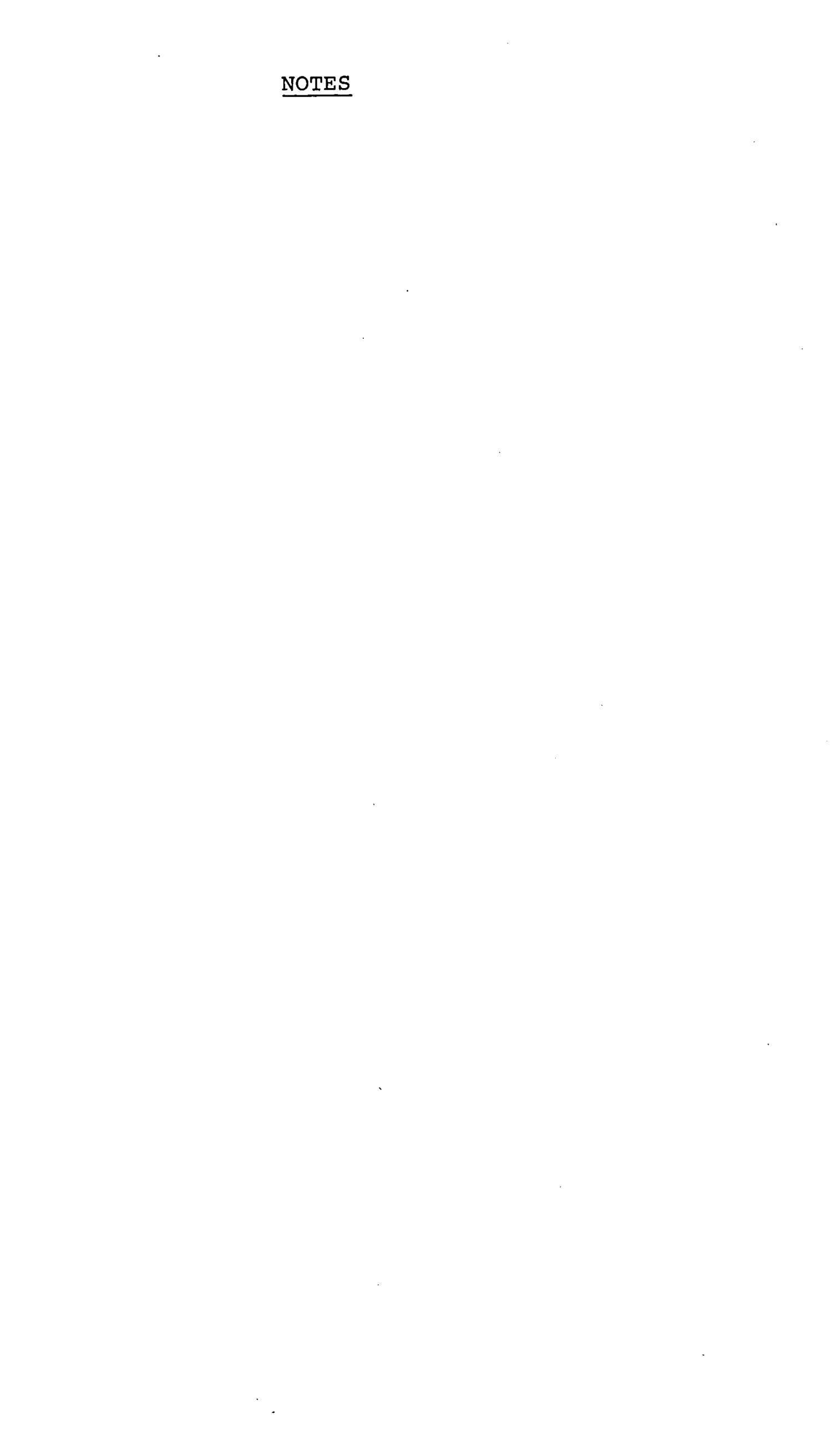
TASK-5: REFINEMENT OF EXISTING INTERPRETATION TECHNIQUES AND DEVELOPMENT OF NEW ONES

Subtask A: Development of Petrophysical Models

For quantitative interpretation of well log data, a "petrophysical model" of the formation must be available. Essentially such a model is an idealized representation of the nature of the formation as it pertains to its fluid storage and flow capacities, as well as some thermal and mechanical properties. There are three basic components in such a model: matrix, pore space, and fluids. These components are described below. Based on such a model, one can derive log response equaticns. These equations can then be used to calculate petrophysical parameters from observed log responses.

Matrix

The matrix is the solid part of the formation. It includes primary matrix minerals, cementing materials, and mineral accumulations that took place after lithification. Any property of the matrix is primarily a function of its mineral composition. The properties of the matrix have a strong influence on the log response of a formation, for matrix volume is usually much larger than the fluid volume in the formation.

Most matrix materials encountered in logging are electrically nonconductive. One notable exception is shale; the wet clay minerals in shale can impart considerable electrical conductivity to the matrix. Another exception is graphite and a group of metallic minerals such as pyrite which are conductive. The conductivity of wet clays is due to ionic double-layer conductivity; that of metallic minerals is due to electronic conduction. Conductivity of shales can vary 
considerably depending on the composition of the shale. The conductivity of pure metallic minerals is less variable. However, the relative arrangement and amounts of the conductive and nonconductive components of a formation matrix determine the overall conductivity of the matrix. Hence, a petrophysical model incorporating the structural arrangement of various matrix components, pores, and fluids is necessary. There are other factors influencing the contribution of the conductive components of a matrix to the overall matrix conductivity. In the case of shale, the salinity of the formation water is such a factor--the higher the formation water conductivity, the lower is the relative effect of clay. Clavier and others (1976) found that for the range of frequencies used in resistivity logging, the relative contribution of pyrite to the overall matrix conductivity is a function of the frequency of the measuring current.

Other physical properties of the matrix such as the bulk density, sonic velocity, hydrogen index, neutron capture cross section, electromagnetic propagation time, etc., also depend on the property of the matrix components. However, matrix properties such as bulk density, neutron capture cross section, and hydrogen index are independent of the relative arrangement of the matrix components, while sonic velocity and electromagnetic propagation time may not be so.

The response equations of many logs include parameters quantifying matrix properties. The most important of such parameters are the sonic travel time $\left(\Delta t_{m a}\right)$, bulk density $\left(\rho_{\mathrm{ma}}\right)$, and the neutron porosity in limestone units ( $\left.\phi_{\mathrm{n}, \mathrm{ma}}\right)$ being required for quantitative analysis of sonic, density, and neutron logs, respectively. The general form of the response equations for most logs can be written as

$$
A=A_{f}(\phi)+A_{m a}(1-\phi),
$$


where A denotes a physical property (such as sonic travel time, bulk density, neutron porosity, neutron capture cross section, electromagnetic propagation time), and $\Phi$ is porosity. Subscripts "ma" and " $f$ " refer to matrix and fluids, respectively. If the matrix is composed of $n$ components, then

$$
A_{m a}=\sum_{i=1}^{n} A_{m a} x_{i}
$$

where $A_{m a, i}$ denotes the physical property and $x_{i}$ the matrix volume fraction of the ith component in the matrix.

In Eq. (1), $A$ is read from a log, and $A_{f}$ and $A_{m a}$ values are usually obtained from tables based on laboratory data. Then $\Phi$ can be calculated. However, if the matrix has more than one component, $x_{i}$ 's need to be known before Eq. (1) can be used to calculate porosity. If $n$ logs are available, $\mathrm{n}$ equations of the form of Eq. (1) can be set up and solved for $n$ unknowns such as $\Phi$ and $x_{1}, x_{2}, \ldots x_{n-1}$.

Then from material balance

$$
x_{n}=1-x_{1}-x_{2}-\ldots x_{n-1}
$$

Thus matrix properties of various minerals and rocks are extremely important in log analysis. Such data are available from the logging manuals only for a limited number of lithologies. The data are scanty or nonexistent for most of the lithologies encountered in geothermal reservoirs.

There are essentially three ways of obtaining data on matrix properties: laboratory measurements, derivation from log responses in "tight" zones, and calculation from multilog suites. Laboratory-derived data reported in the Iiterature are usually obtained under ambient condition, while the reservoir condition is different--the pressure and temperature are higher. Some matrix properties such as the sonic 
velocities (shear or compressional) are functions of temperature (Somerton and others, 1974; Timur, 1976). This fact should be considered in interpreting geothermal well logs. Matrix properties can sometimes be derived from logs through "tight" zones. If a well section is known to be nonporous ("tight"), its log response is the same as the matrix response for the lithology around the well bore. When a multilog suite is available, one can set up a number of linear response equations, as explained earlier, and solve these equations. The unknowns in these equations are usually the porosity and the relative volume of the various matrix components. However, if either porosity or the relative volumes of some components are known, then some matrix properties can be calculated. For example, given the density and neutron logs through a formation with a two-component matrix of known composition, one can calculate the porosity of the formation and $\phi_{n, m a}$ of one of the components, if $\phi_{n, m a}$ of the other component and the bulk densities of both components are known. Such estimates can often be made with the help of logging charts or crossplots. For some logs it is difficult to use the concept of "matrix property" quantitatively. For example, the gamma-ray log response of a formation is a function of the amount (usually minute) of radioactive minerals in the formation. It is difficult to assign a "typical" gamma-ray response to any particular lithologic component. Nevertheless, the gamma-ray $\log$ is used to estimate the bulk volume shale fraction in a formation by assuming that the gamma-ray responses of adjacent shale and "clean" sand beds are the same as the gamma-ray responses of the "shale" and "sand" fractions, respectively, in the matrix of the formation in question. The petrophysical model usualiy employed for the calculation of the bulk volume shale fraction $\left(V_{s h}\right)$ is

$$
V_{s h}=\frac{G R-G R}{G_{s h}-G R_{s d}},
$$


where $G R, G_{s d}$, and $G_{S h}$ are the gamma-ray intensities of the zone under study, of sand, and of shale, respectively. Equation (4) tends to overestimate $\mathrm{V}_{\mathrm{sh}}$. A more accurate version of the model gives

$$
V_{s h}=\frac{G R \cdot \rho-G R_{s d} \cdot \rho s d}{G_{s h} \cdot \rho_{s h}-G_{s d} \rho_{s d}}
$$

where $\rho$ is the bulk density (obtained from a density log) of the zone under study, and $\rho_{\text {sd }}$ and $\rho_{\text {sh }}$ are the bulk densities of the zones at which $\mathrm{GR}_{\mathrm{sd}}$ and $\mathrm{GR}_{\mathrm{sh}}$ are read. Usually, this $\mathrm{V}_{\mathrm{sh}}$ is also too high (Dresser Atlas, 1977).

The SP log measures the spontaneous potential, which consists of electrochemical and streaming potential components. streaming potential is independent of the matrix properties but is an indirect function of pore geometry. Electrochemical potential is a function of the relative content of some matrix components, such as shale and the chemical characteristics of the formation and borehole fluids.

Interpretation of temperature logs may require knowledge of the thermal properties (thermal conductivity and specific heat) of the matrix. If the matrix of a known composition and the specific heats of each component are known then the overall specific heat (C) of the matrix can be calculated as

$$
c=\sum_{i=1}^{n} c_{i} x_{i}
$$

when $C_{i}$ and $x_{i}$ are the specific heat and the mass fraction (in matrix), respectively, of the $i$ th component, and $\mathrm{n}$ is the number of components. However, no such simple relation is available for estimating the thermal conductivity of a complex lithology. 
Pore Space

The pore space in a petrophysical model implies space within the rock that is not occupied by matrix material. Two important characteristics of pore spaces that need to be accounted for in petrophysical models are the pore geometry (or pore structure) and the amount of pore space relative to the matrix volume, usually expressed as fraction of the bulk volume of the rock (porosity). Porosity may be subdivided into different types; intergranular, fracture, vuggy, vesicular, and oolitic porosities.

Intergranular porosity means spaces left between the grains of a matrix, and are generally interconnected and fairly regular. Porosities of this type are present in most sedimentary formations. Fracture porosity may be naturally caused by geologic events after deposition or is sometimes artifically generated by hydraulic or explosive fracturing to enhance formation permeability. Fracture porosity can be present in all types of formations; however, it is dominant in igneous and metamorphic rocks. Vuggy porosity is caused by solution of the matrix material, and the vugs may or may not be interconnected. This type of porosity is of common occurrence in carbonate formations. Vesicular porosity is sometimes encountered in volcanic rocks. This porosity is caused when the gas released from a cooling lava is trapped as a series of gas bubbles throughout the matrix. It should be pointed out that for vuggy and vesicular porosities there is no limit to the amount of pore space per volume of matrix, whereas, for intergranular porosities the pore space will not exceed about 44 percent of the total bulk volume. An extreme case of vesicular porosity is seen in pumice, which is so porous that it floats on water. Oolitic porosity is encountered in some formations deposited in marine environments. Oolitic pores can be divided into micropores, which include the spaces within the oolites and are very small 
pores; and the pore space between the oolites is referred to as interoolitic pores. Micropores miay occur in nonoolitic carbonates and in the cementing material of clastic sediments (Kieke and Hartmann, 1973).

\section{Fluids}

The fluid present in the pore spaces of a geothermal reservoir is either steam or water. Steam has practically infinite resistivity compared to water. The resistivity of formation water defends on the salinity and temperature of the water.

Petrophysical Models for Geothermal Reservoirs

Because of the extremely diverse lithologies and pore structures encountered in cieothermal reservoirs, it is impossible to have a unique petrophysical model for all geothermal systems. We discuss briefly below some of the most applicable petrophysical models for geothermal log analysis.

1) Intergranular porosity, sedimentary clastic rock without any shale--For resistivity response, the Archie's formula is adequate (Schlumberger, 1972). For porosity logs, standard response equations are applicable. This is known as a "clean sand" model.

2) Intergranular forosity, shaly clastic rocks--Since the presence of shale affects the responses of many well logs, the interpretation of shaly formations is more involved than "clean" formations. Shaliness affects log responses depending on the proportion of shale and its physical properties and the distribution of shale in the formation. The three shale models generally accepted are the following. Laminar shale: shale 
exists in the form of laminae between which are layers of sand. Structural shale: It exists as grains or nodules in the formation matrix. Dispersed clay: In this case clay is dispersed throughout, partially filling the interstices. It should be pointed out that the three forms of shale may be present simultaneously in the same formation. Schlumberger (1974) provides considerable details of typical shaly formation log analysis.

3) Carbonates with intergranular porosity--This model is similar to the previous ones, except that the presence of shale is usually not a problem, the cementation factor can be generally considered to be 2.0 , and the degree of compaction in carbonates is quite high and fairly uniform.

4) Nonconductive matrix with fracture porosity, for example, fractured igneous and metamorphic rocks--The detection and evaluation of fractures is important in geothermal log analysis. The methods available, however, are limited to gross sections where a statistically significant number of zones are available. Analyses of different cases have shown that the cementation exponent ranges from 1.1 to 1.3 for fractured systems. It has also been found that unless the environment is highly fractured the sonic velocity will be unaffected by the presence of fractures. Aguilera (1977) has discussed log analysis in naturally fractured reservoirs. In a later section in this report we have discussed the various techniques for locating fractures from well logs. For igneous rocks, the influence of bound water in minerals must be accounted for in log analysis (Nelson and Glen, 1975). For igneous and metamorphic geothermal reservoirs, the effect of hydrothermal alteration in $\log$ response must be considered. 
5) Matrix with a conductive metallic mineral, such as pyrite--Both the amount and structural arrangement of the conductive mineral in the rock will affect the log responses. The effect of pyrite on log response has been discussed by Clavier and others (1976); the results are summarized in this report under Task 1 in the section on Laboratory Investigations.

6) Metamorphic Rocks--For lightly metamorphosed rocks, models should be same as for their sedimentary counterparts, unless there is significant development of secondary minerals; for example, refer to the work of Ritch (1975) discussed under Task 1.

7) Volcanic ash and tuff--Refer to the discussion on the work of Khatchikian and Lesta (1973) and Sacco (1978) under Task 1 .

8) Vuggy and oolite carbonates--Models for vuggy carbonates are the same for other carbonates except for the consideration of secondary porosity. No model has been specifically developed for oolite carbonates. Vugs will not alter the sonic log response.

9) Vesicular volcanic rocks--For interconnected vesicular system, probably Archie's formula will hold. It is not known to what extent the sonic log response will be affected by vesicular porosity. The other aspects of vesicular rock will be similar to that for other igneous rocks.

At this time we are still developing quantitative models. For example, under Task 4, preliminary quantitative models for a mainly volcanic and sedimentary rock sequence (Raft River) and for a granite basement rock (Fenton Hill) sequence are given as examples. 


\section{REFERENCES}

Aguilera, Roberto, and Van Poolen, H. K., "Current Status of the Study of Naturally Fractured Reservoirs," The Log Analyst, May-June 1977.

Clavier, C., Heim, A., and Scala, C., "Effect of Pyrite on Resistivity and Other Logging Measurements," Transactions, SPWLA Seventeenth Annual Logging Symposium, Denver, Colorado, June 1976.

Dresser Atlas, "Log Interpretation," 1977, Chart 7-2.

Khatchikian, A. and Lesta, P., "Log Evaluation of Tuffites and Tuffaceous Sandstone in Southern Argentina," Transactions, SPWLA Fourteenth Annual Logging Symposium, Lafayette, Louisiana, June 1973.

Kieke, E. M. and Hartmann, D. J., "The Influence of Micro Porosity on Formation Evaluation and Use of the Scanning Electron Microscope to Gain New Insight into Pore Geometry," Paper No. SPE4531, 48th Annual Fall Meeting of the SPE of AIME, Las Vegas, September 1973.

Nelson, P. H. and Glen, W. E., "Influence of Bound Water on the Neutron Log in Mineralized Igneous Rock," SPWLA Sixteenth Annual Logging Symposium, New Orleans, Louisiana, June 1975.

Ritch, H. J., "An Open Hole Logging Evaluation in Metamorphic Rock," SPWLA Sixteenth Annual Logging Symposium, New Orleans, Louisiana, June 1975.

Sacco, E. L., "Carbon/Oxygen Log Applications in Shaly Sand Formations Contaminated with Tuffite Minerals," SPWLA Nineteenth Annual Logging Symposium, El Paso, Texas, June 1978.

Schlumberger, "Log Interpretation - Volume I - Principles," 1972 .

Schlumberger, "Log Interpretation - Volume II - Applications," 1974 .

Somerton, W. H., El-Shaarani, A. H., and Mobarak, S. M., "High Temperature Behavior of Rocks Associated with Geothermal Type Reservoirs," Paper No. SPE4899, 44th Annual California Regional Meeting of the SPE of AIME, San Francisco, California, April 1974.

Timur, A., "Temperature Dependence of Compressional and Shear Wave Velocities in Rocks," SPWLA Seventeenth Annual Logging Symposium, Denver, Colorado, 1976. 
Subtask B: Matrix Response

The matrix and response values are classified and listed in four tables.

Table 5.b.l: Hierarchical Relationship of Minerals

Table 5.b.2: Hierarchical Relationship of Rocks

Table 5.b.3: Matrix Values for Minerals

Táble 5.b.4: Matrix Values for Rocks

Table 5.b.1 and Table 5.b.2 classify minerals and rocks into groups of similar composition and assign a reference code. Table 5.b.3 and Table 5.b.4 list the minerals and rocks in alphabetical order along with the matrix values and hierarchical code.

Rocks and minerals may be easily located and crossreferenced with members of the same group.

Note: References in this task have been assigned a letter rather than listed in alphabetical order. This allows simplification of listings given in Tables 5.b.3 and 5.b.4. 
TABLE 5.b.1: HIERARCHICAL RELATIONSHIP OF MINERALS

\section{ORTHO- \& RING SILICATES}

1.1 OLIVINE GROUP

1.1 .1 Olivine: $(\mathrm{Mg}, \mathrm{Fe})_{2}\left[\mathrm{SiO}_{4}\right]$

1.1.1.1 Forsterite: $\mathrm{Mg}_{2} \mathrm{SiO}_{4}$

1.1.1.2 Fayalite: $\mathrm{Fe}_{2} \mathrm{SiO}_{4}$

2. CHAIN SILICATES

2.1 PYROXENE GROUP

2.1.1 Enstatite-Orthoferrosilite: ( $\left.\mathrm{Mg}, \mathrm{Fe}^{+2}\right)\left[\mathrm{SiO}_{3}\right]$

2.1.1.1 Enstatite/Clinoenstatite: $\mathrm{Mg}_{2} \mathrm{Si}_{2} \mathrm{O}_{6}$

2.1.1.2 Orthoferrosilite/Clinoferrosilite: $\mathrm{Fe}_{2} \mathrm{Si}_{2} \mathrm{O}_{6}$

2.1 .2 Diopside-Hedenbergite: $\mathrm{Ca}(\mathrm{Mg}, \mathrm{Fe})\left[\mathrm{Si}_{2} \mathrm{O}_{6}\right]$

2.1.3 Augite-Ferroaugite: $\quad\left(\mathrm{Ca}, \mathrm{Na}, \mathrm{Mg}, \mathrm{Fe}^{+2}, \mathrm{Mn}, \mathrm{Fe} \mathrm{H}^{+3}, \mathrm{Al}, \mathrm{Ti}\right)_{2}$

$$
\left[(\mathrm{Si}, \mathrm{Al})_{2} \mathrm{O}_{6}\right]
$$

\section{SHEET SILICATES}

\subsection{MICA GROUP}

3.1 .1 Muscovite: $\mathrm{K}_{2} \mathrm{Al}_{4}\left[\mathrm{Si}_{6} \mathrm{Al}_{2} \mathrm{O}_{20}\right](\mathrm{OH}, F)_{4}$

3.1 .2 Glauconite: $\quad(\mathrm{K}, \mathrm{Na}, \mathrm{Ca}) 1.2-2.0^{\left(\mathrm{Fe}^{+3}, \mathrm{Al}, \mathrm{Fe}^{+2}, \mathrm{Mg}\right)} 4.0$

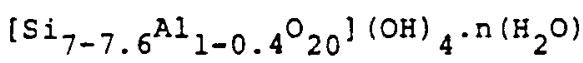

3.1.3 Phlogopite: $\mathrm{K}_{2}\left(\mathrm{Mg}, \mathrm{Fe}^{+2}\right)_{6}{ }^{\left[\mathrm{Si}_{6} \mathrm{Al}_{2} \mathrm{O}_{20}\right](\mathrm{OH}, \mathrm{F})_{4}}$

$$
\text { 3.1.3.1 Eastonite: } \mathrm{K}_{2} \mathrm{Mg}_{5} \mathrm{Al}\left[\mathrm{Si}_{5} \mathrm{Al}_{3} \mathrm{O}_{20}\right](\mathrm{OH})_{4}
$$

3.1.4 Biotite: $\mathrm{K}_{2}\left(\mathrm{Mg}, \mathrm{Fe}^{+2}\right)_{6-4}\left(\mathrm{Fe}^{+3}, \mathrm{Al}, \mathrm{Ti}\right)_{0-2}\left[\mathrm{Si}_{6-5^{\mathrm{Al}}} 2-3_{20} \mathrm{O}\right.$ $(\mathrm{OH}, \mathrm{F})_{4}$

3.1.4.1 Annite: $\mathrm{K}_{2} \mathrm{Fe}_{6}{ }^{\left[\mathrm{Si}_{6} \mathrm{AI}_{2} \mathrm{O}_{20}\right](\mathrm{OH})_{4}}$

3.1.4.2 Siderophyllite: $\mathrm{K}_{2} \mathrm{Fe}_{5} \mathrm{Al}\left[\mathrm{Si}_{5} \mathrm{Al}_{3} \mathrm{O}_{20}\right](\mathrm{OH})_{4}$ 
3.2 CHLORITE/SEPTECHLORITES

3.2.1 Chlorite: (Mg, Al, Fe ${ }_{12}\left[(\mathrm{Si}, \mathrm{Al})_{8} \mathrm{O}_{20}\right](\mathrm{OH})_{16}$

3.2.1.1 Daphnites: $\left(\mathrm{Fe}_{4} \mathrm{Al}_{2}\right)\left[\left(\mathrm{Si}_{2} \mathrm{Al}_{2}\right) \mathrm{O}_{10}\right](\mathrm{OH})_{8}$

3.2.2 Septechlorite: $\quad \mathrm{Y}_{6}\left[\mathrm{Z}_{4} \mathrm{O}_{10}\right](\mathrm{OH})_{8}$

3.2.2.1 Amesite: $\left(\mathrm{Mg}_{4} \mathrm{AI} 2\right)\left[\left(\mathrm{Si}_{2} \mathrm{Al}_{2}\right) \mathrm{O}_{10}\right](\mathrm{OH})_{8}$

3.2.3 Serpentine: $\mathrm{Mg}_{3}\left[\mathrm{Si}_{2} \mathrm{O}_{5}\right](\mathrm{OH})_{4}$

3.2.3.1 Antigorite: $\mathrm{Mg}_{3}\left[\mathrm{Si}_{2} \mathrm{O}_{5}\right](\mathrm{OH})_{4}$

3.2.3.2 Ferroantigorite: $\mathrm{Fe}_{3}\left[\mathrm{Si}_{2} \mathrm{O}_{5}\right](\mathrm{OH})_{4}$

3.3 CLAY MINERALS

3.3.1 Kaolinite Group: $\mathrm{Al}_{4}\left[\mathrm{Si}_{4} \mathrm{O}_{10}\right](\mathrm{OH})_{8}$

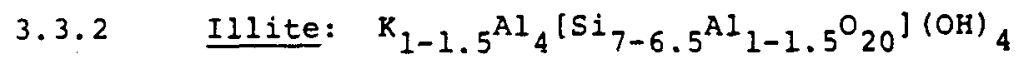

3.3 .3 Montmorillorite Group: $\quad(1 / 2 \mathrm{Ca}, \mathrm{Na})_{0.7}(\mathrm{Al}, \mathrm{Mg}, \mathrm{Fe})_{4}$

$\left[(\mathrm{Si}, \mathrm{Al})_{8} \mathrm{O}_{20}\right](\mathrm{OH})_{4} \cdot \mathrm{nH}_{2} \mathrm{O}$

\section{FRAMEWORK SILICATES}

4.1 FELDSPAR GROUP

4.1.1 Alkali Feldspars: (K,Na) $\left[\mathrm{AlSi}_{3} \mathrm{O}_{8}\right]$

4.1 .1 .1 Orthoclase: $\mathrm{KAlSi}_{3} \mathrm{O}_{8}$

4.1.2 Plagioclase Feldspars: $\mathrm{Na}\left[\mathrm{AlSi}_{3} \mathrm{O}_{8}\right]-\mathrm{Ca}\left[\mathrm{Al} \mathrm{Si}_{2} \mathrm{O}_{8}\right]$

4.1.2.1 Albite: $\mathrm{NaAlSi}_{8} \mathrm{O}_{8}$

4.1.2.2 Anorthite: $\mathrm{CaAl}_{2} \mathrm{Si}_{2} \mathrm{O}_{8}$

4.2 SIIICA MINERALS

4.2.1 Quartz: $\mathrm{SiO}_{2}$

4.2.1.1. Quartz: $\mathrm{SiO}_{2}$

4.2.1.2 Opal: $\mathrm{SiO}_{2} \cdot \mathrm{nH}_{2} \mathrm{O}$

4.2.1.3 Chert: $\mathrm{SiO}_{2}$

4.2.1.4 Flint: $\mathrm{SiO}_{2}$

4.3 ZEOLITE GROUP

4.3.1 zeolites: $\left.\quad\left(\mathrm{Na}_{2}, \mathrm{~K}_{2}, \mathrm{Ca}, \mathrm{Ba}\right)[\mathrm{Al}, \mathrm{Si}) \mathrm{O}_{2}\right] \mathrm{n}, \mathrm{xH}_{2} \mathrm{O}$ 


\section{NON-SILICATES}

5.1 OXIDES

5.1 .1

Hematite: $\mathrm{Fe}_{2} \mathrm{O}_{3}$

5.1 .2 Ilmenite: $\mathrm{FeTiO}_{3}$

5.1 .3 Spinel Group

5.1.3.1 Magnetite: $\mathrm{Fe}^{+2} \mathrm{Fe}_{2}{ }^{+3} \mathrm{O}_{4}$

5.2 HYDROXIDES

5.2 .1

Limonite: $2 \mathrm{FeO}_{3} \cdot 3 \mathrm{H}_{2} \mathrm{O}$

5.3 SULFIDES

5.3 .1

Pyrite: $F_{2}$

5.3 .2

Pyrrhotite: $\mathrm{Fe}_{n} \mathrm{~S}_{n+1}$

5.4 SULFATES

5.4 .1

Barite: $\mathrm{BaSO}_{4}$

5.4 .2

Celestite: $\mathrm{SrSO}_{4}$

5.4 .3

Gypsum: $\mathrm{CaSO}_{4} \cdot 2 \mathrm{H}_{2} \mathrm{O}$

5.4 .4

Anhydrite: $\mathrm{CaSO}_{4}$

5.4 .5

Langbeinite: $\mathrm{K}_{2} \mathrm{SO}_{4} \cdot 2 \mathrm{MgSO}_{4}$

5.4 .6

Polyhalite: $\mathrm{K}_{2} \mathrm{SO}_{4} \cdot \mathrm{MgSO}_{4} \cdot 2 \mathrm{CaSO}_{4} \cdot 2 \mathrm{H}_{2} \mathrm{O}$

5.4 .7

Kainite: $\mathrm{KMg}\left(\mathrm{SO}_{4}\right) \mathrm{Cl} \cdot 3 \mathrm{H}_{2} \mathrm{O}$

5.4 .8

Kieserite: $\mathrm{MgSO}_{4} \cdot \mathrm{H}_{2} \mathrm{O}$

\subsection{CARBONATES}

5.5 .1

Calcite: $\mathrm{CaCO}_{3}$

5.5 .2

Siderite: $\mathrm{FeCO}_{3}$

5.5.

Dolomite: $\operatorname{CaMg}\left(\mathrm{CO}_{3}\right)_{2}$

5.5 .4

Aragonite: $\mathrm{CaCO}_{3}$

5.5 .5

Trona: $\mathrm{Na}_{2} \mathrm{CO}_{3} \cdot \mathrm{NaHCO}_{3} \cdot 2 \mathrm{H}_{2} \mathrm{O}$

5.5 .6

Nahcolite: $\mathrm{NaHCO}_{3}$ 


\subsection{PHOSPHATES}

5.6.1 Cellophane: $\mathrm{Ca}_{3}\left(\mathrm{PO}_{4}\right)_{2}-\mathrm{H}_{2} \mathrm{O}$

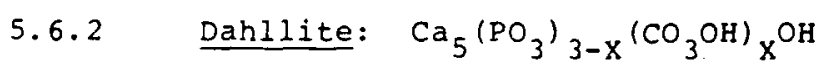

5.7 BORATES

5.7 .1 Kernite: $\mathrm{Na}_{2} \mathrm{~B}_{4} \mathrm{O}_{6}(\mathrm{OH})_{2} \cdot 3 \mathrm{H}_{2} \mathrm{O}$

5.8 HALIDES

5.8.1 Halite (Salt): NaCl

5.8 .2 Sylvite: $\mathrm{KCl}$

5.8.3 Carnallite: $\mathrm{KCl} . \mathrm{MgCl}_{2} 6 \mathrm{H}_{2} \mathrm{O}$

5.9 NATIVE ELEMENTS

5.9 .1 Sulfur: $S_{8}$

5.9.a Graphite: C

5.10 COAL

5.10 .1 Lignite:

5.10 .2 Bituminous coal:

5.10.3 Anthracite Coal: 
TABLE 5.b. 2: HIERARCHICAL RELATIONSHIP OF ROCKS

1. SEDIMENTARY ROCKS

\subsection{CLASTICS}

1.1.1 Sandstone (Primarily quartz)

1.1.1.1 Unconsolidated

1.1.1.2 Consolidated

1.1.2 Siltstone (Primarily quartz, very fine grained)

1.1.3 Shale (Primarily clay minerals and fine-

grained quartz)

1.1.4 Greywacke

1.2 NON-CLASTICS

1.2.1 Iimestone (Primarily Calcite)

1.2.2 Dolomite (Primarily Dolomite)

1.3 VOLCANIC DEBRIS

1.3.1 Volcanic Ash (Composition variable)

1.3.2 Tuff (Composition variable)

2. IGNEOUS ROCKS (See Figure 5.b.1)

2.1 GRANITE-RHYOLITE FAMILY

$2.1 .1 \quad$ Plutonic Class

2.1.1.1 Granite

2.1.1.2 Granodiorite

2.1.1.3 Syenite

2.1.1.4 Monzonite

2.1.2 Volcanic Class

2.1.2.1 Rhyolite

2.1.2.2 Obsidian 
TABLE 5.b.2: HIERARCHICAL RELATIONSHIP OF ROCKS

\subsection{DIORITE-ANDESITE FAMILY}

$\begin{array}{ll}2.2 .1 & \frac{\text { Plutonic Class }}{2.2 .1 .1 \quad \text { Diorite }} \\ 2.2 .2 \quad \frac{\text { Volcanic Class }}{3.3 .3 .1 \quad \text { Andesite }}\end{array}$

2.3 GABBRO-BASALT FAMILY

\begin{tabular}{ll}
2.3 .1 & \multicolumn{2}{l}{ Plutonic Class } \\
$2.3 .1 .1 \quad$ Gabbro \\
$2.3 .1 .2 \quad$ Norite \\
$2.3 .1 .3 \quad$ Diabase \\
$2.3 .1 .4 \quad$ Dunite \\
$2.3 .1 .5 \quad$ Anorthosite \\
$2.3 .2 \quad$ Volcanic Class \\
$2.3 .2 .1 \quad$ Basalt \\
3. METAMORPHIC ROCKS (See Figure 5.b.2)
\end{tabular}


Figure 5.b.1

Diagram showing order or crystallization of the common rockforming minerals.

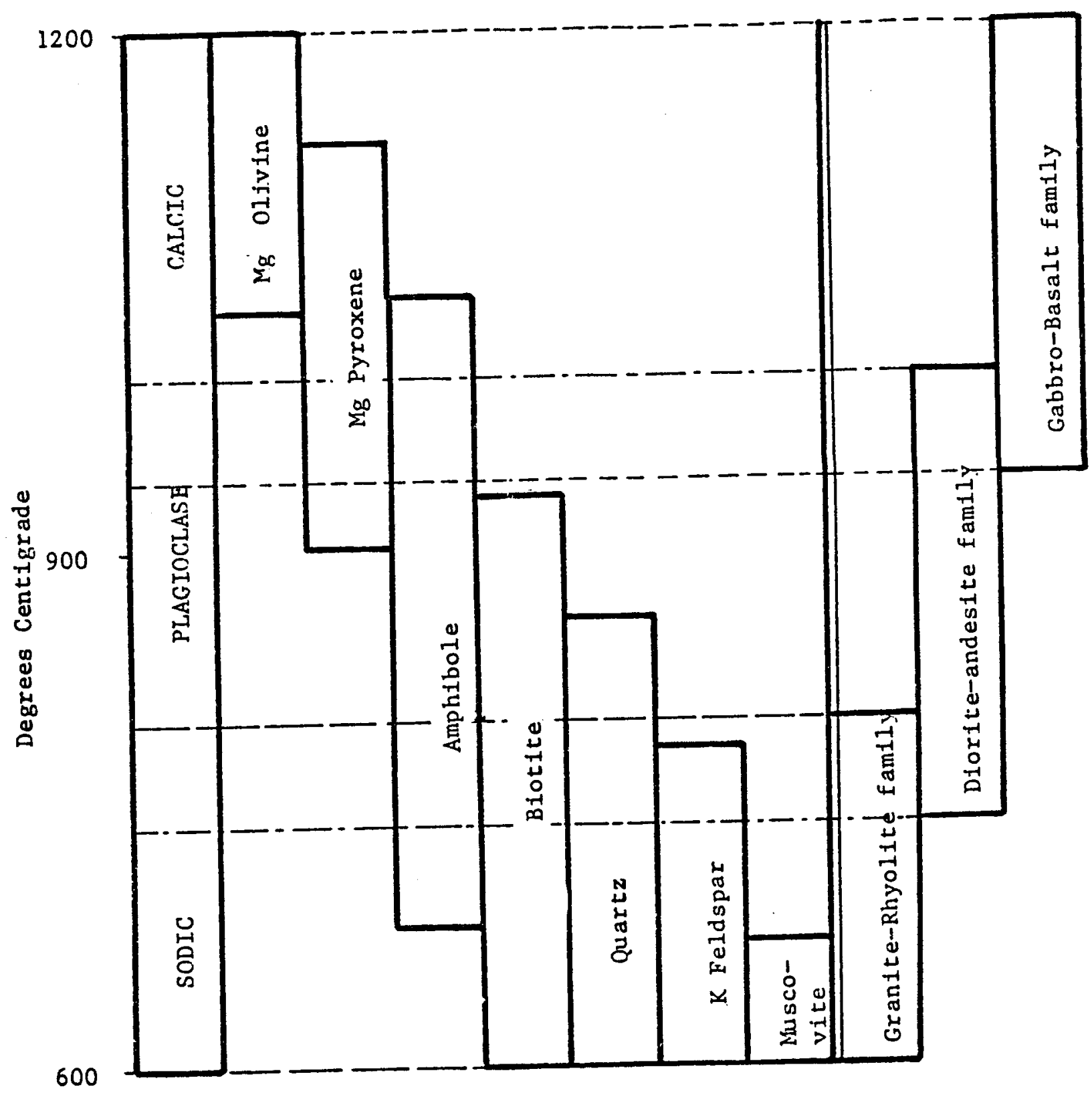


Figure 5.b. 2

Classification of metamorphic rocks.

1. FOLIATED

\begin{tabular}{|c|c|c|c|c|c|c|c|c|c|}
\hline \multicolumn{3}{|c|}{ TEXTURE } & \multicolumn{5}{|c|}{ COMPOS ITION } & & ROCK NAME \\
\hline \multirow{4}{*}{ 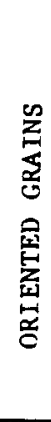 } & \multirow{3}{*}{ 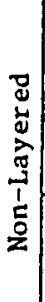 } & $\begin{array}{l}\text { Very Elne } \\
\text { grained }\end{array}$ & & & & & & & SLATE \\
\hline & & grained & 总 & $\stackrel{3}{\Sigma}$ & \multirow{2}{*}{ 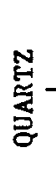 } & & & & PHYILITE \\
\hline & & gralued & & & & \multirow{2}{*}{$\begin{array}{l}\text { 号 } \\
\text { 点 } \\
\text { 悬 }\end{array}$} & \multirow{2}{*}{ 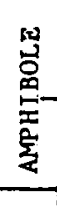 } & $\vec{b}$ & SCAIST \\
\hline & $\stackrel{a}{a}$ & $\begin{array}{l}\text { Coarse } \\
\text { grained }\end{array}$ & & & & & & בัँ & GNEISS \\
\hline
\end{tabular}

2. NON-FOIIATED

\begin{tabular}{|c|c|c|}
\hline TEXTURE & COMPOSITION & ROCK NAME \\
\hline $\begin{array}{l}\text { Coarse } \\
\text { grained }\end{array}$ & $\begin{array}{l}\text { Deformed Iragments of } \\
\text { Any Rock Type }\end{array}$ & $\begin{array}{l}\text { META- } \\
\text { CONGLOMERATE }\end{array}$ \\
\hline \multirow{2}{*}{$\begin{array}{l}\text { Fine to } \\
\text { Coarse grained }\end{array}$} & Quartz & QUARTZITE \\
\hline & Calcite or Dolomite & MARBLE \\
\hline
\end{tabular}




\section{TABLES OF MATRIX AND RESPONSE VALUES}

The following two tables are listings of the matrix and response values for density, sonic, and neutron logs.

TABLE 5.b.3: Values for Minerals as classified in TABLE 5.b.I.

TABLE 5.b.4: Values for Rocks as classified in TABLE 5.b.2. EXPLANATION OF TABLES $5 . \mathrm{b} .3 \& 5 . \mathrm{b} .4$

\section{MINERAL/ROCK and CODE COlumn.}

This column lists the name of the mineral or rock in alphabetical order. Below the name is the code for the hierarchical relationship as given in TABLES 5.b.1 \& 5.b.2.

\section{DENSITY Column.}

The density column may have up to five rows of data. Unit for all rows is grams per cubic centimeter.

Row 1: Specific Gravity and reference source.

Row 2: Range of Specific Gravity and reference source. If a number is listed in place of a reference letter, the reference is the same as the row immediately above. The number is the quantity of samples from which the range of values were derived.

Row 3: Apparent matrix density based on a tool calibration with $\mathrm{Z} / \mathrm{A}$ ratio of 0.5 . (Refer to reference $F$ for additional explanation.) When no reference was found for this row, a value was computed from the chemical formula 
and the Specific Gravity in Row 1. If this average value was not available, the apparent matrix density was computed using the mid-value of the range given in Row 2 .

Row 4: Actual log reading of rock or mineral.

Row 5: Apparent matrix values as determined by charts or crossplots. Method used noted with reference.

\section{SONIC Column.}

The sonic column may have up to five rows of data.

Row I: Average matrix travel time in microseconds per foot and reference source.

Row 2: Range of matrix travel time and reference source. If a number is listeci in place of a reference letter, the reference is the same as the row immediately above. The number is the quantity of samples from which the range of values were derived.

Row 3: The average matrix travel time in microseconds per meter.

NOTE: Laboratory measurements given may have been made at Standard Temperature and Pressure or at simulated overburden pressure. The difference may be significant. Refer to individual listing and Reference $\mathrm{R}$.

Row 4 \&

Row 5: Same as described for density column, except sonic data is listed. Units are microseconds per foot. 
NEUTRON COIUMn.

The neutron column may list either a value or a range in Row 1 in percentage units. Of the three responses 1 isted, the neutron response varies with tool type more than the others. For the most part, neutron tools may be grouped in three classes.

A. Thermal neutron - single detector - large hole size effect - moderate matrix effect.

B. Thermal neutron - dual detector, compensated small hole size effect - greatest matrix effect.

C. Epithermal neutron - single detector, pad type small hole size effect - low matrix effect.

To determine the neutron response for all the neutron classes and tool configurations would be a monumental undertaking. A method of computing a rough estimate, based strictly on hydrogen content, is described in Reference $B$. Where possible, a note is made with the reference as to the particular tool, class, or estimation from hydrogen content. When individual commercial tool is listed, the response is given in limestone units.

Rows 4 and 5 are the same as described for density column, except neutron data is listed in percentage units. 
SCIENTIFIC SOFTAARE CORPORATION

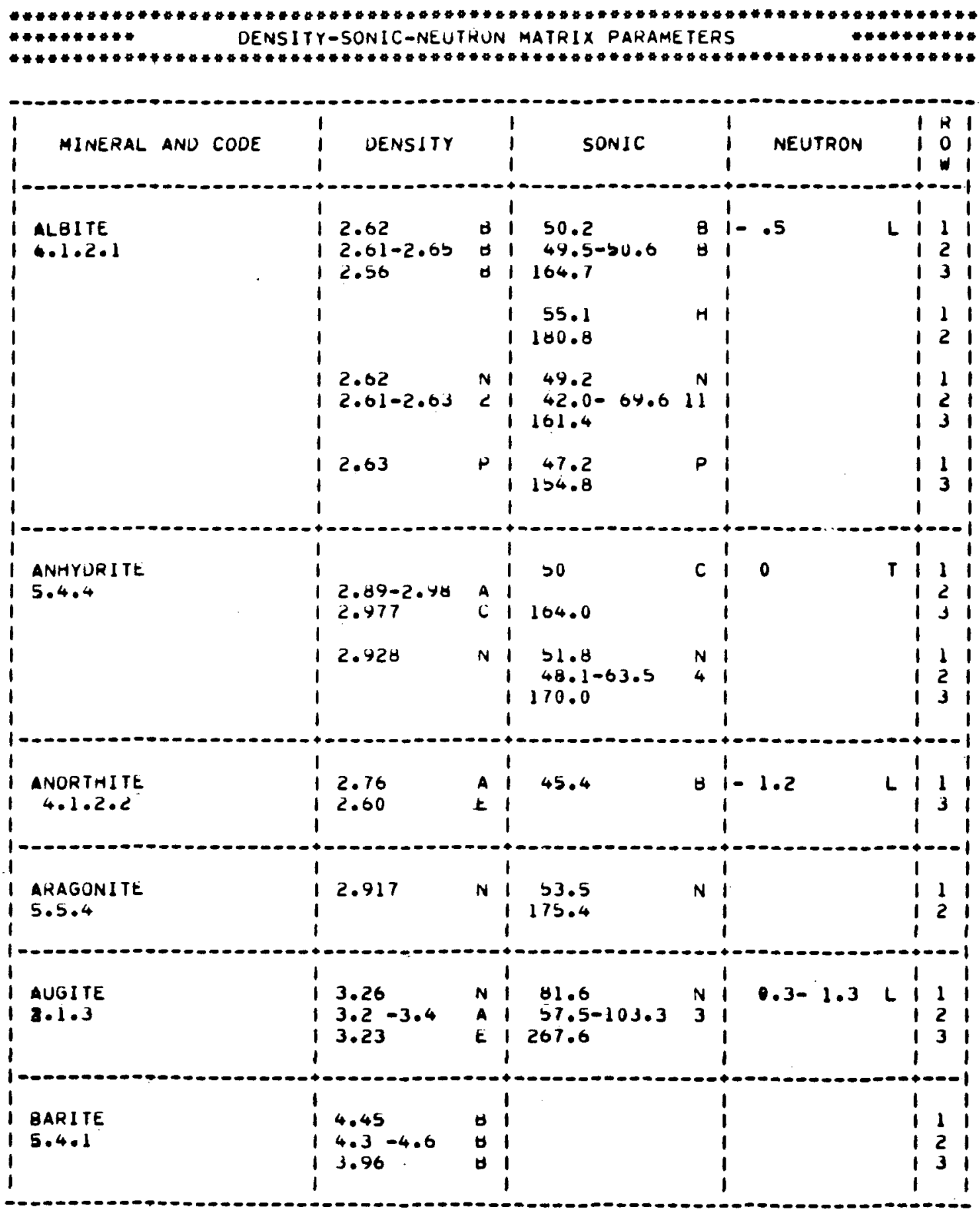

TABLE 5, B.3. PAGE I 


\section{SCIENTIFIC SOFTWARE CORPORATION}

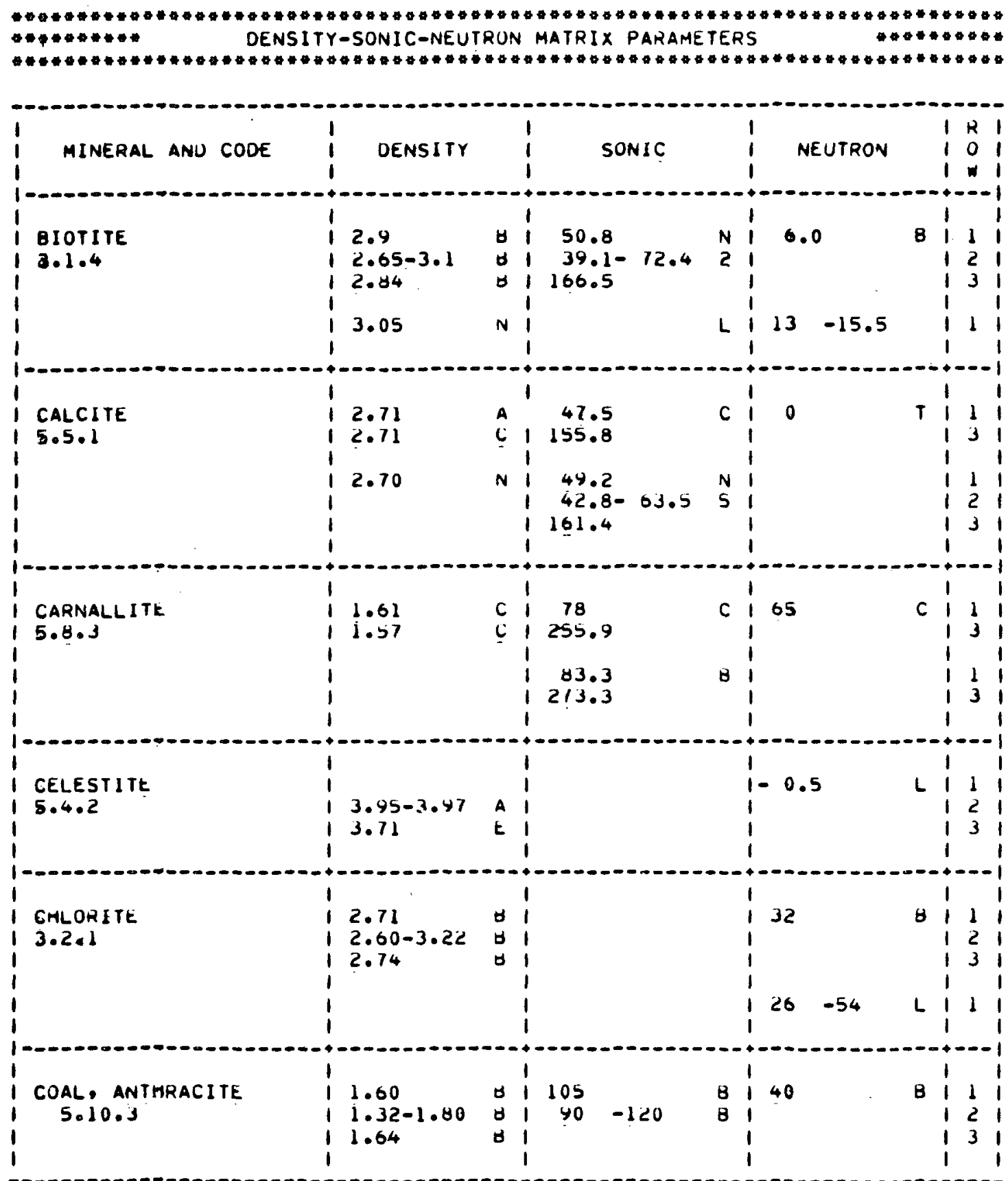

TABLE Y.B.3, PAGE 2 


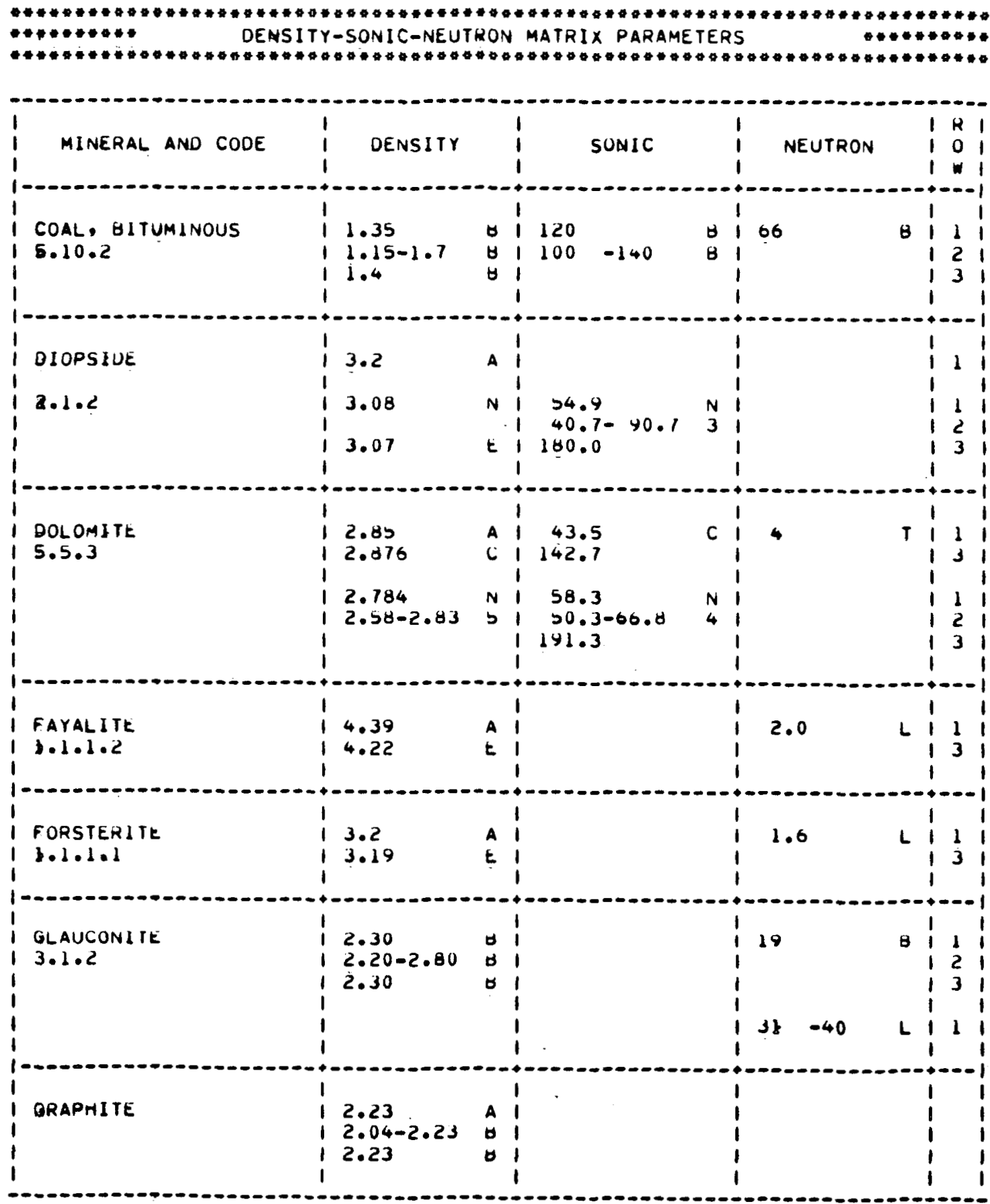

TABLE S.H.3. PAGE 3 
SCIENTIFIC SOFTWARE CORPORATION

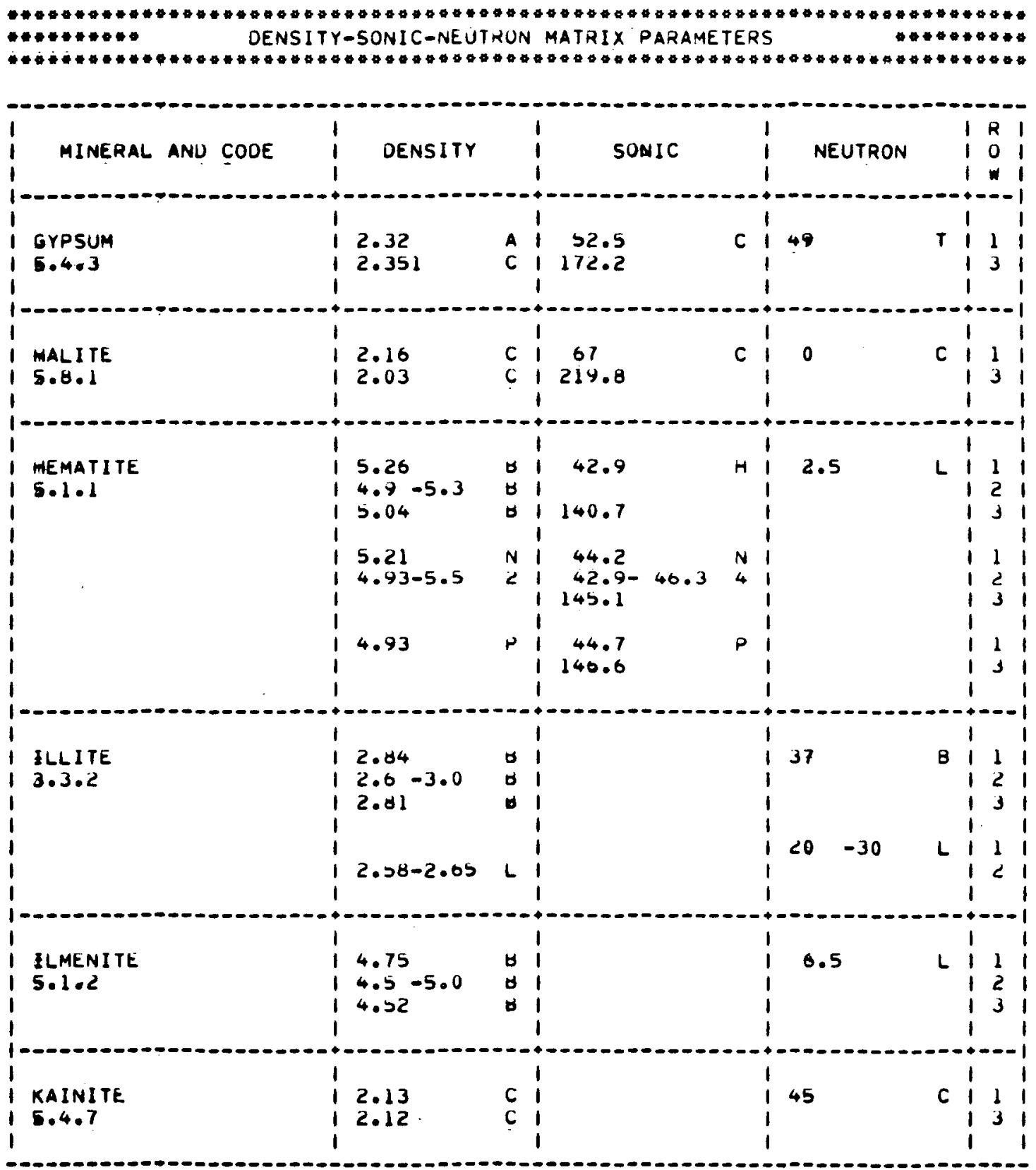

TABLE 5.H.3. PAGE 4 
SCIENTIF IC SOF TWARE CORPURATION

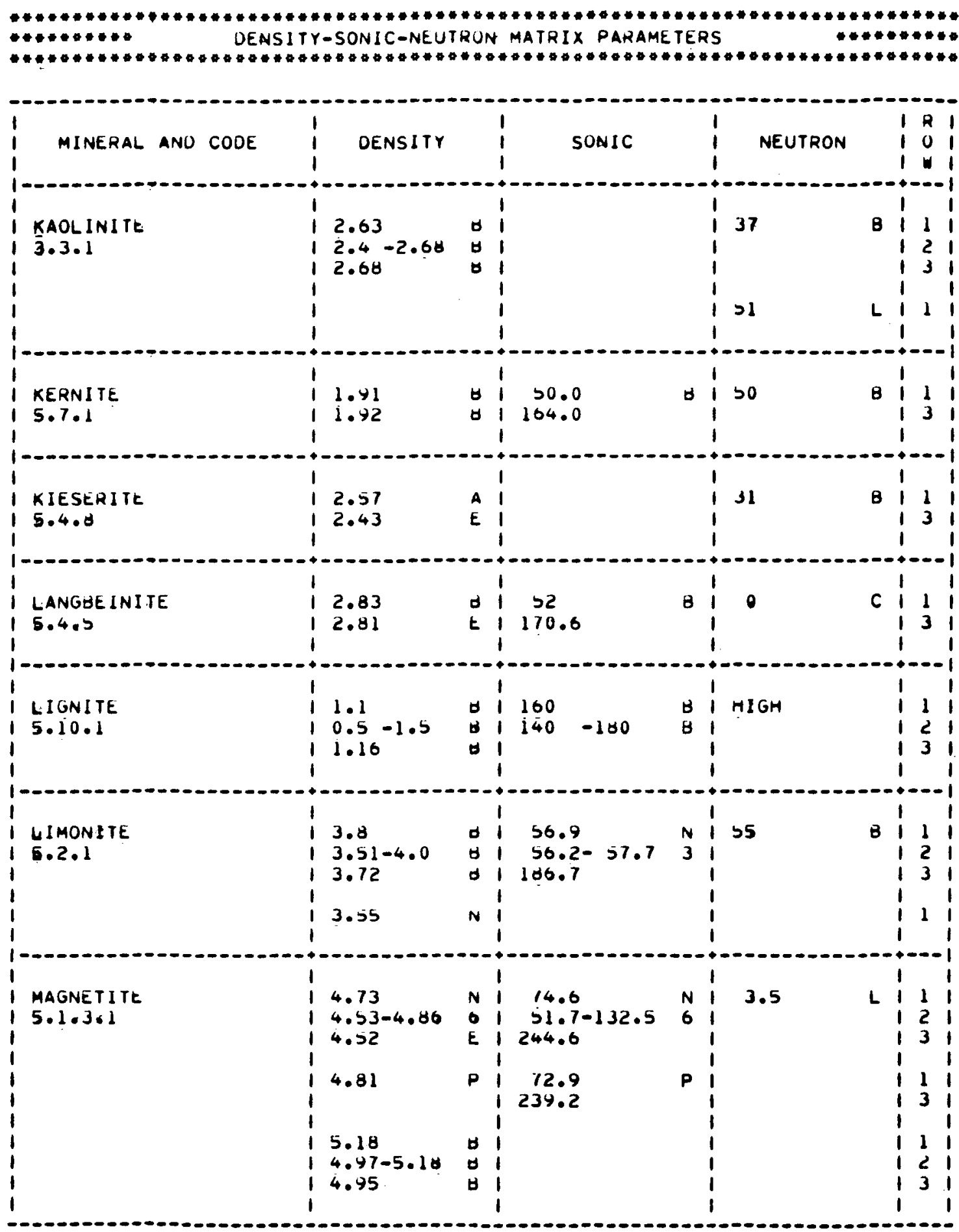

TABLE 5.8.3, PAGE 5 


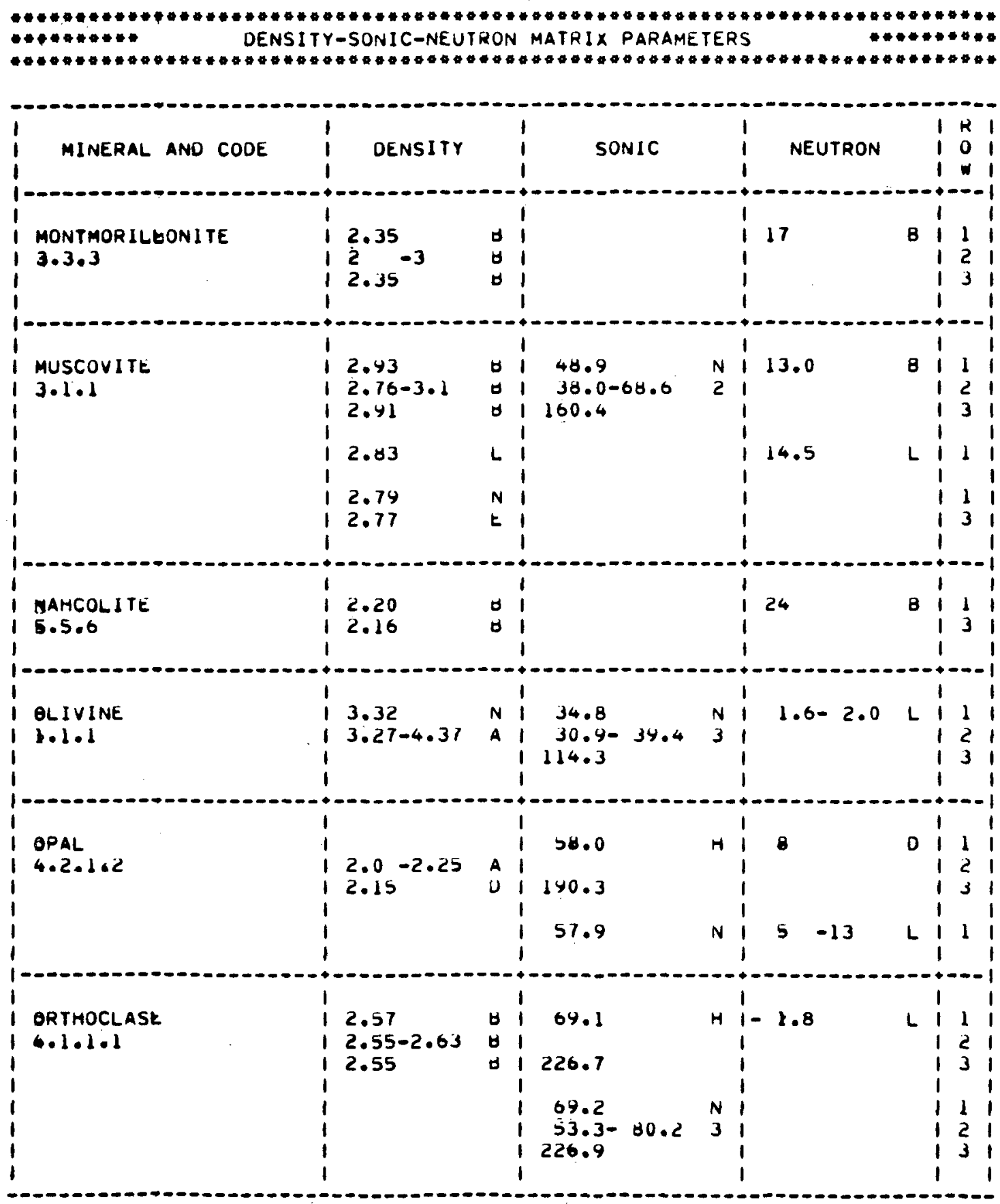

TABLE 5.4.3, PAGE 0 


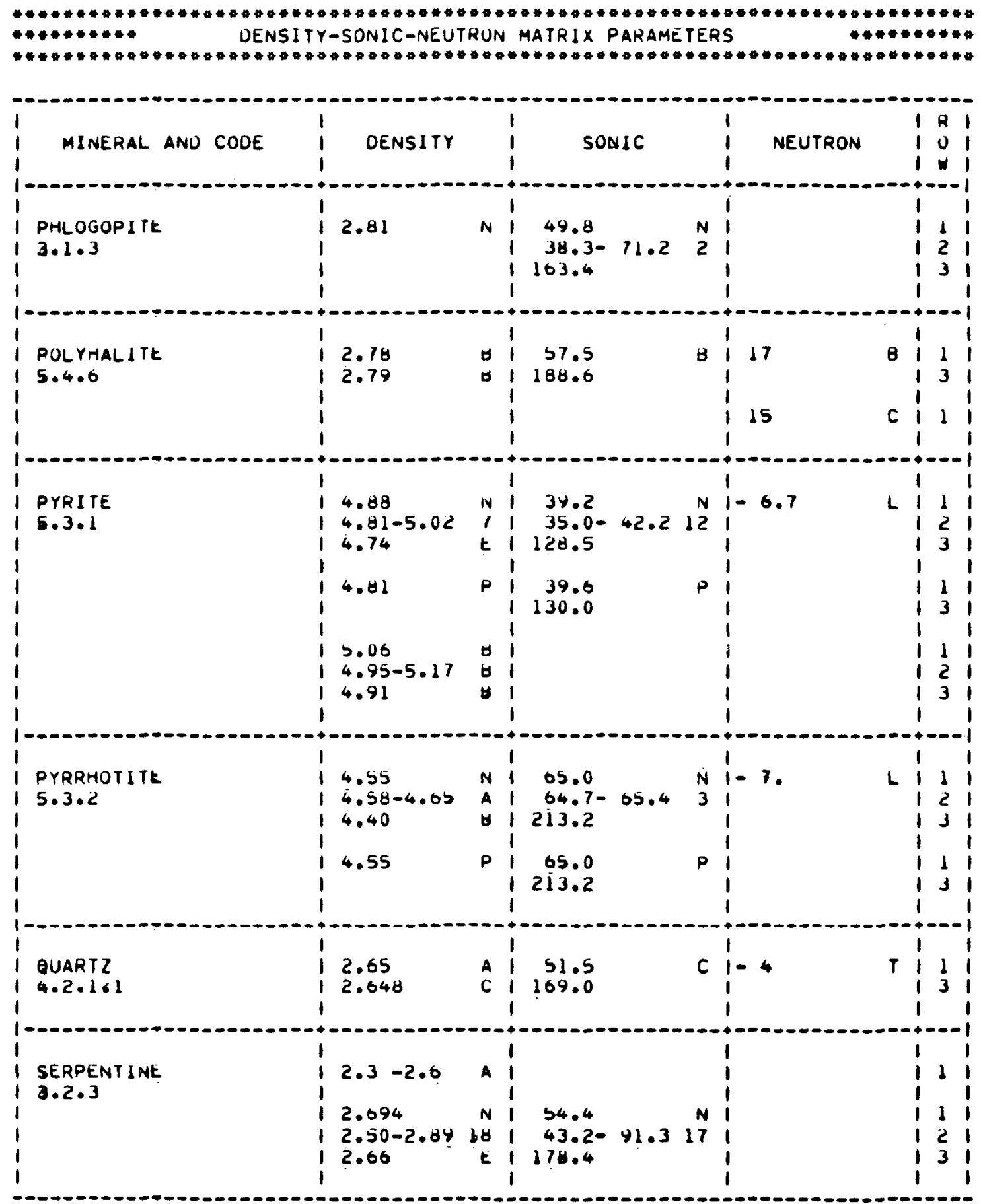

TABLE 5.8.3. PAGE 7 
SCIENTIFIC SOF TWARE CORPORATION

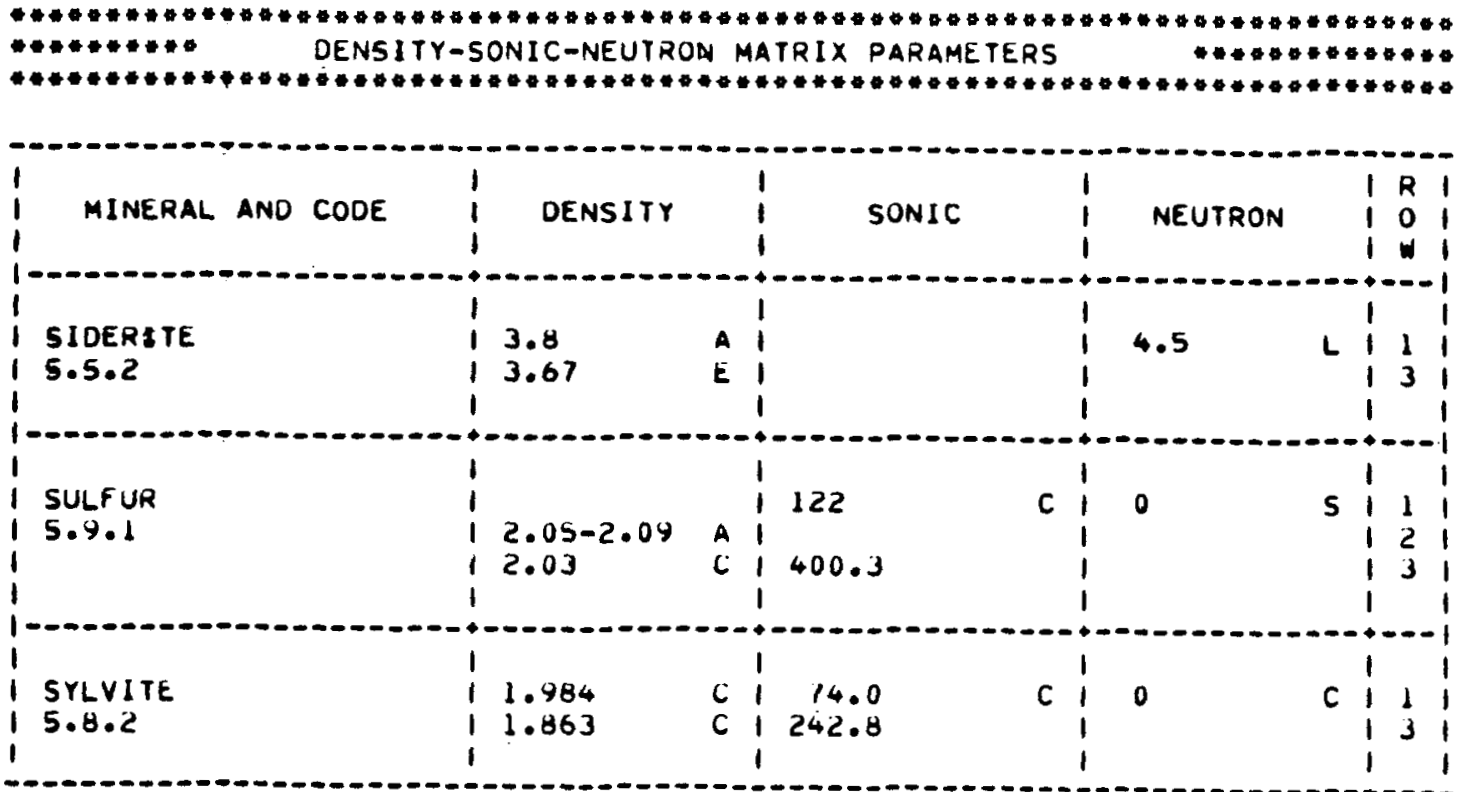


SCIENTIFIC SOH TWARE CORPORATION

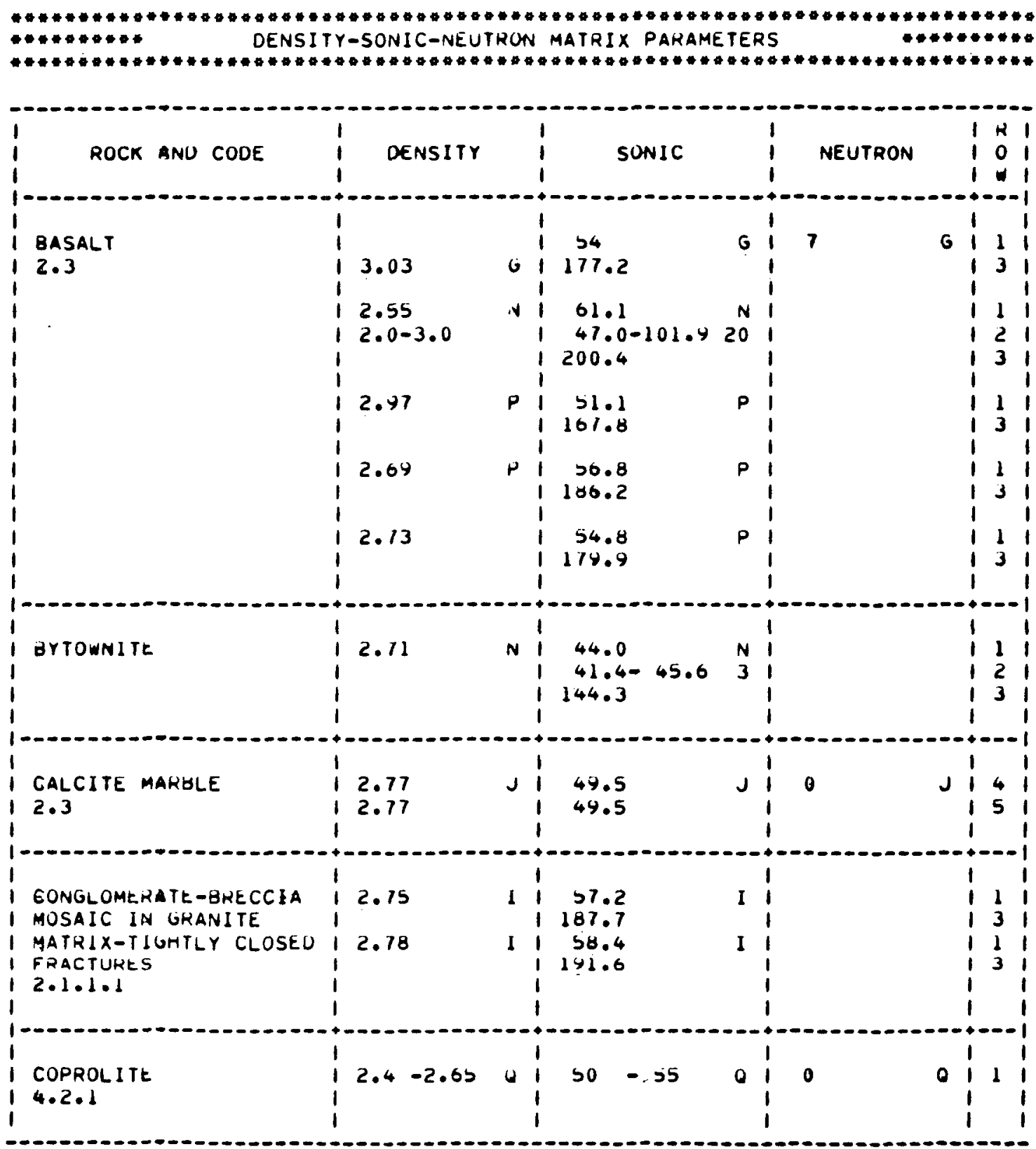

TABLE 5.B.4. PAGE 1 


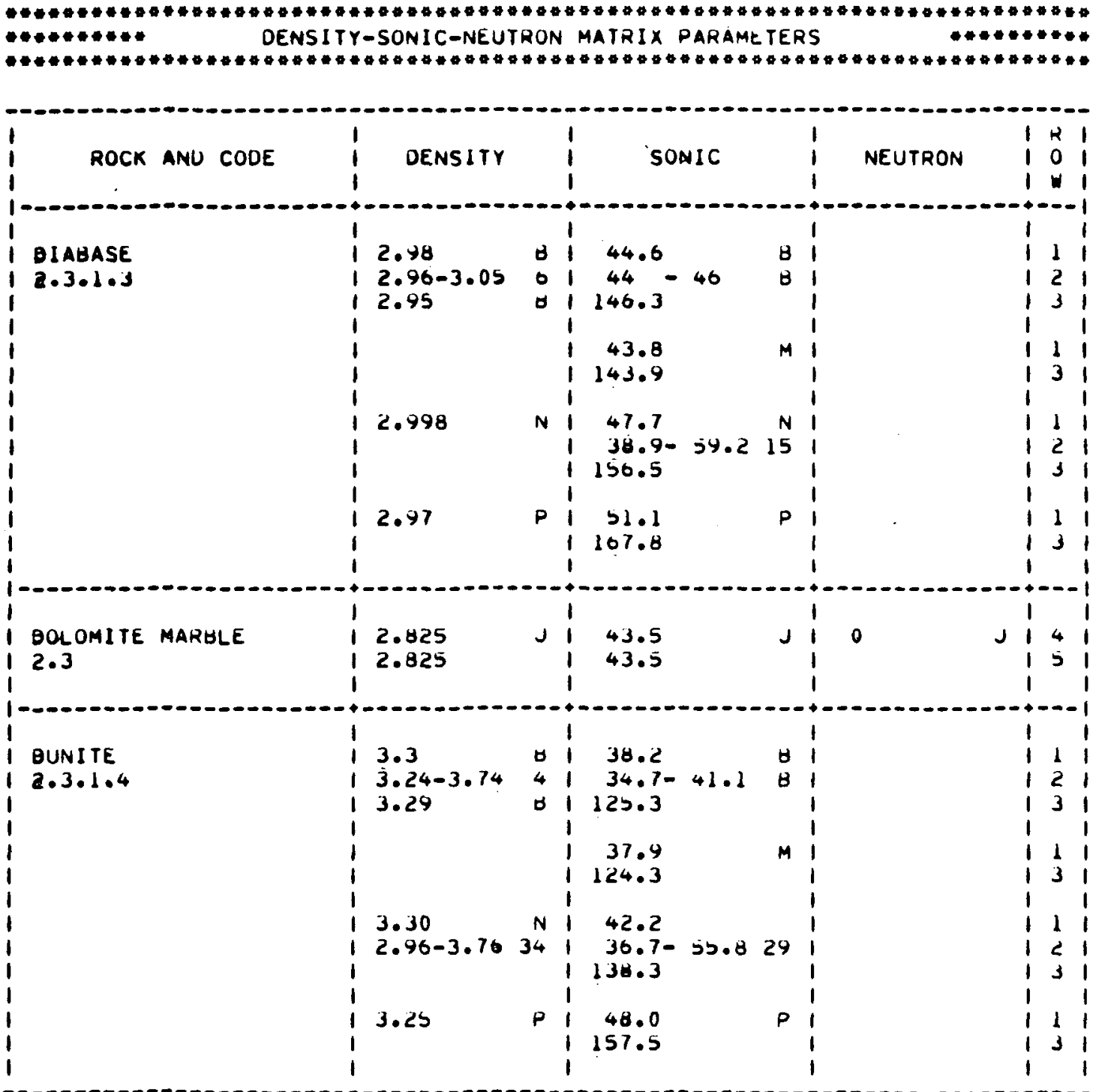

TABLE 5.8.4, PAGE 2 


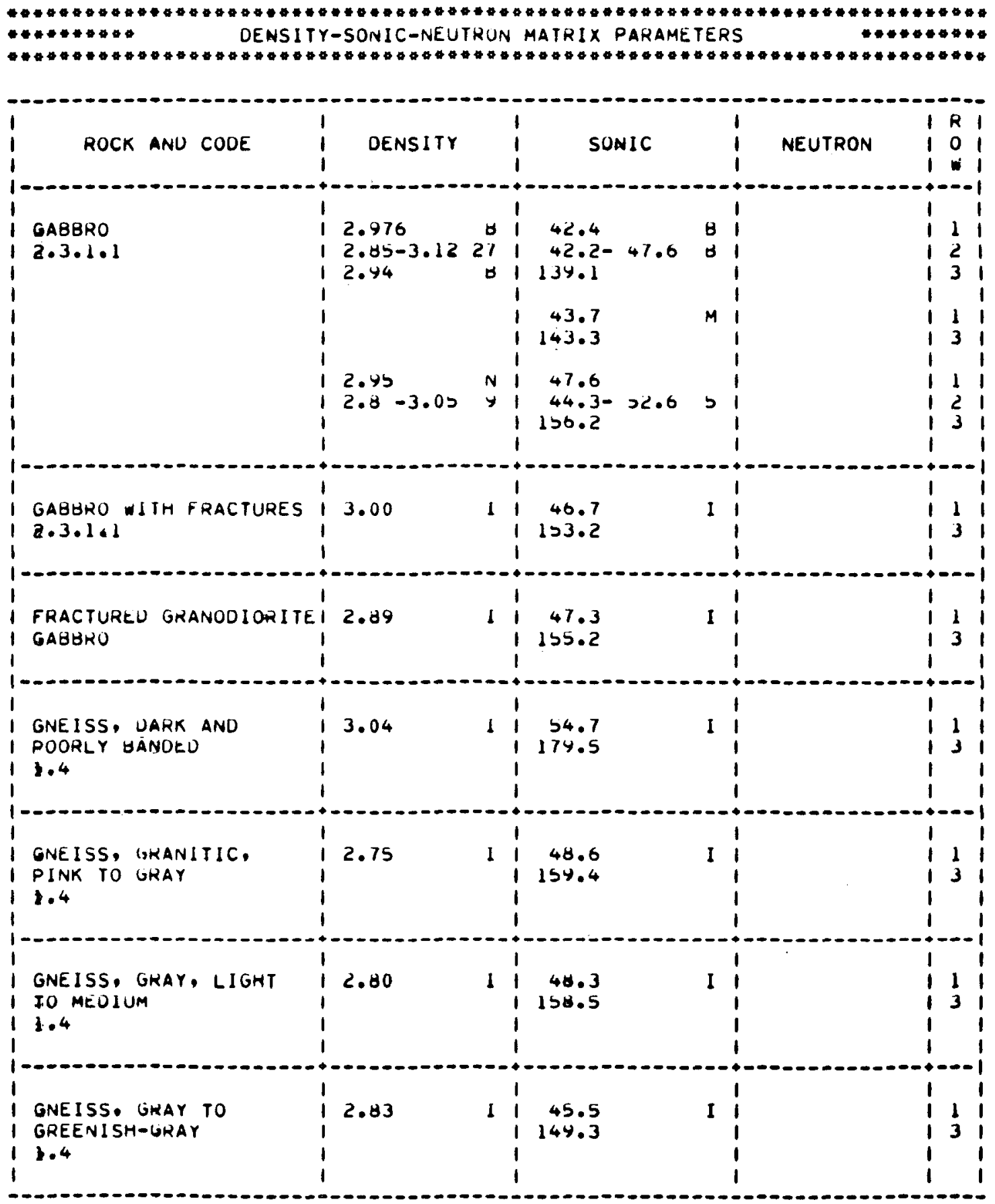

TABLE 5.8.4, PAGE 3 
SCIENTIFIC SOFTWARE CORPORATION

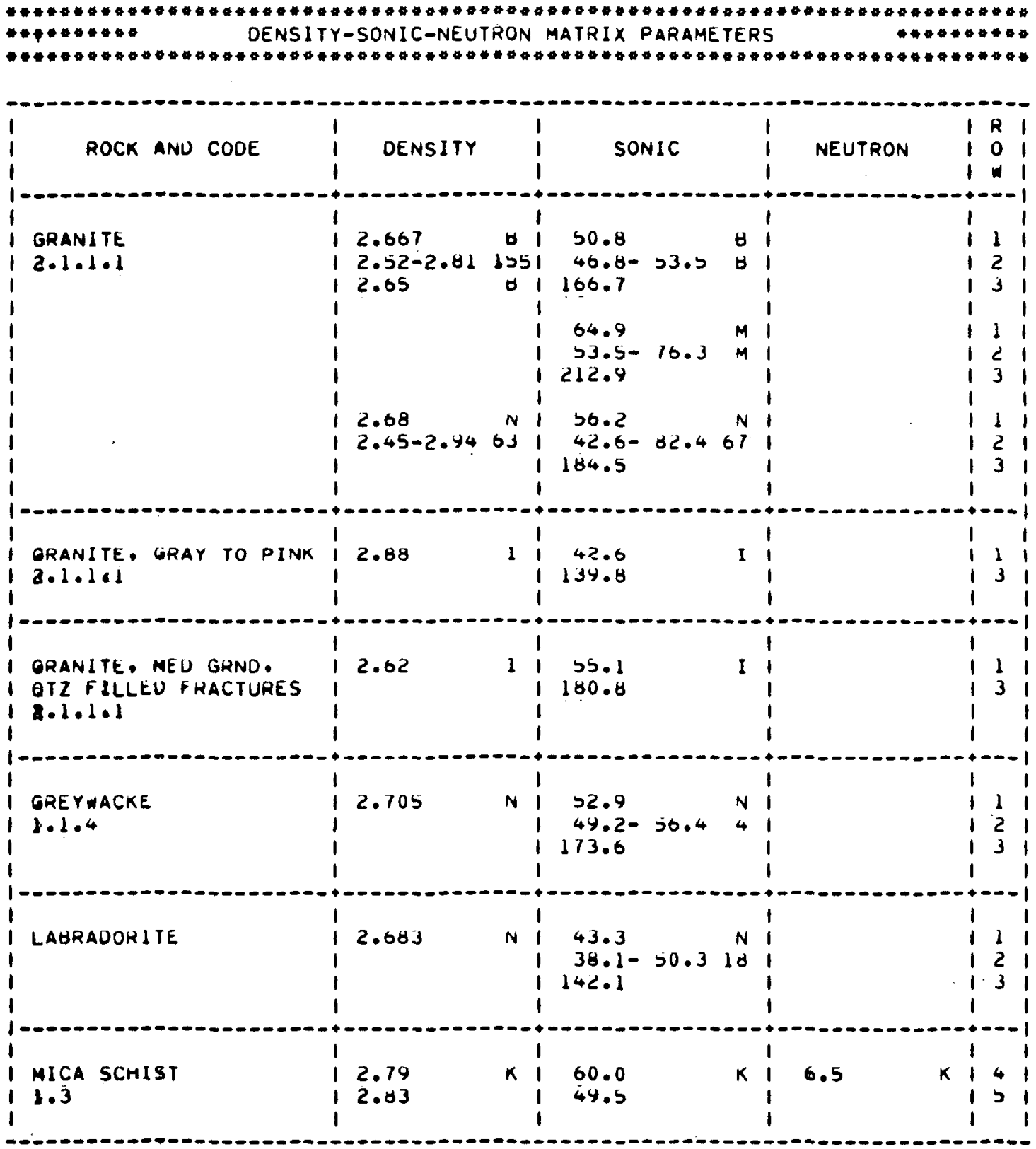

TABLE 5.8.4, PAGE 4 
SCIENTIFIC SOFTWARE CORPORATION

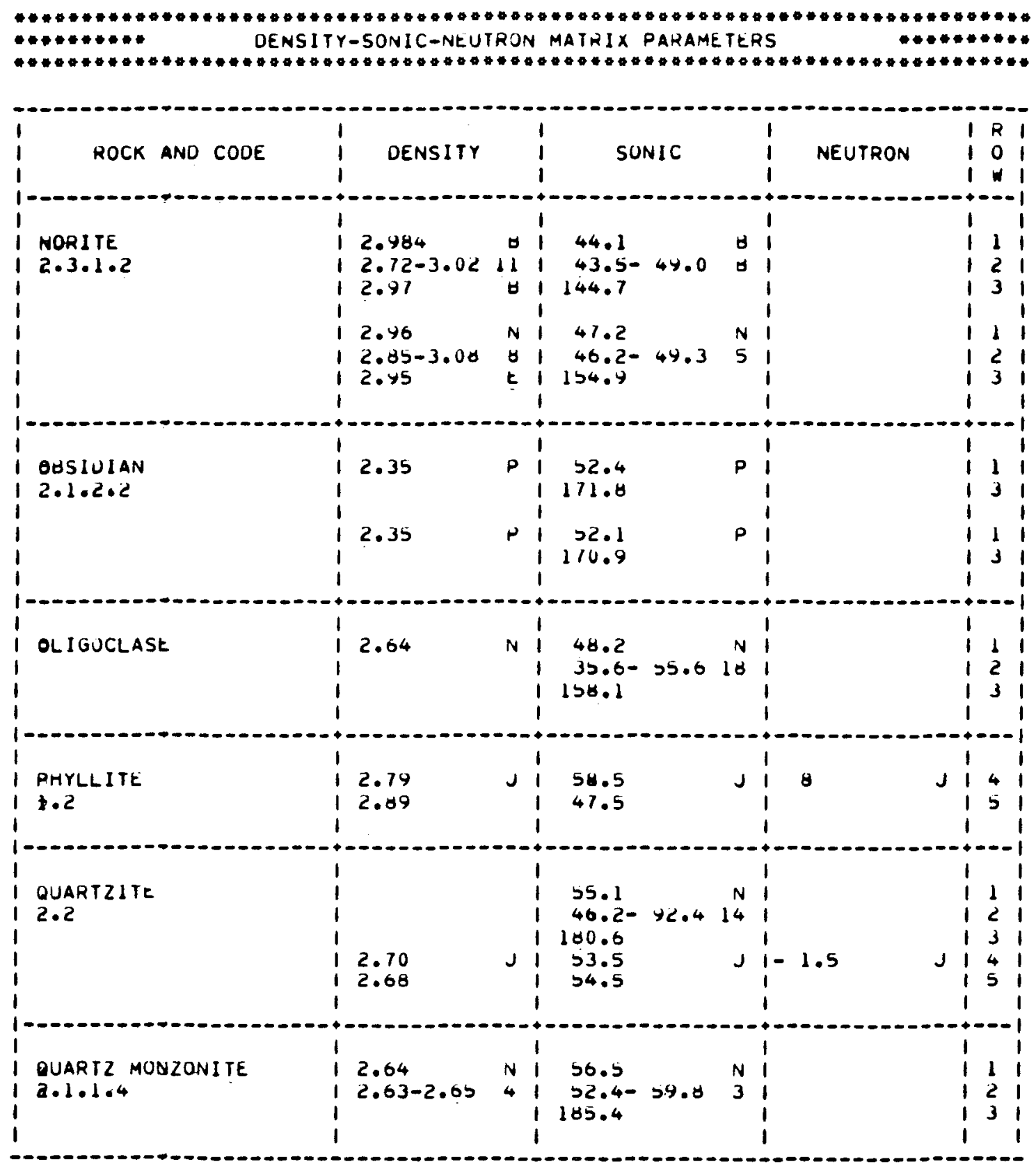

TABLE 5.B.4, PAGE 5 


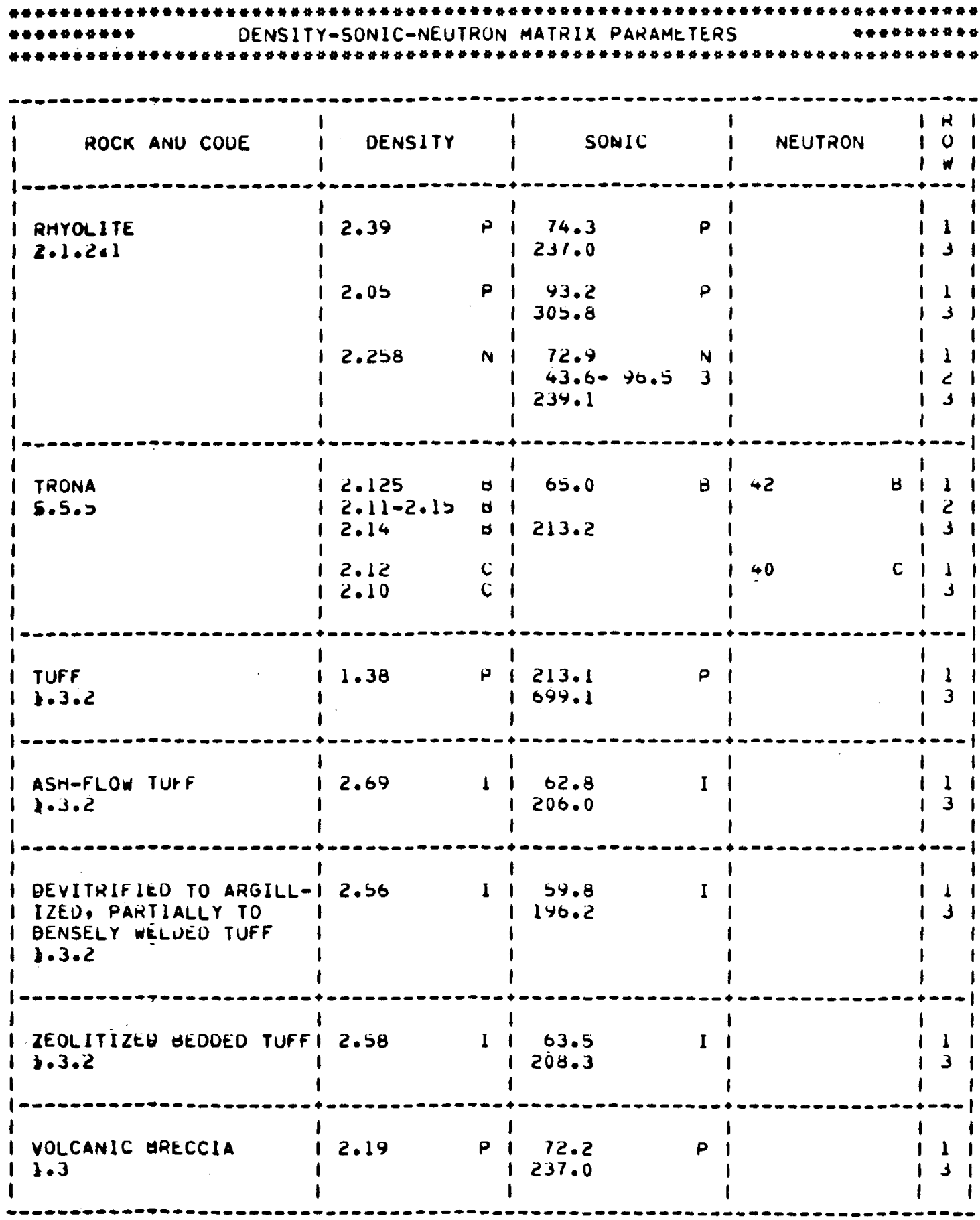

TAGLE $\$ . \forall .4$, PAGE 6 


\section{REFERENCES FOR MATRIX PARAMETERS}

A. Cornelius S. Hurlbut, Jr. and Cornelis Klein, "Manual of Mineralogy," 19 th ed. John Wiley and Sons, New York, (1977).

B. Gearhart-Owen, "Formation Evaluation Data Handbook," (1978). Neutron values based on hydrogen content.

C. M. P. Tixier and R. P. Alger, "Log Evaluation of Nonmetallic Mineral Deposits," Trans., SPWLA Eighth Annual Logging Symposium, (1967). Neutron values for Schlumberger "GNT" (Class A).

D. T. W. Ehring, L. A. Lusk, J. M. Grubb, R. B. Johnson, M. R. DeVries, W. H. Fertl, "Formation Evaluation Concepts For Geothermal Resources," Trans., SPWLA Nineteenth Annual Logging Symposium, (1978).

E. Computed, based on tool calibration $\mathrm{Z} / \mathrm{A}$ ratio of 0.5 .

F. J. Tittman and J. S. Wahl, "The Physical Foundations of Formation Density Logging (Gamma-Gamma)," Geophysics, Vol. XXX, No. 2, (April 1965).

G. R. P. Alger, Personal Communication, (1975). Neutron value for Schlumberger "SNP" (Class C).

H. M. R. J. Wyllie, A. R. Gregory, and L. W. Gardner, "Elastic Wave Velocities in Heterogeneous and Porous Media," Geophysics, Vol. XXI, No. 1, (January 1956). Acoustical measurements made at $25^{\circ} \mathrm{C}$ and atmospheric pressure.

I. John I. Myung and Donald P. Helander, "Correlations of Elastic Moduli Dynamically Measured By In-Situ and Laboratory Techniques," SPWLA Thirteenth Annual Logging Symposium, (1972). Matrix values computed from listed laboratory measurements and core analysis. Laboratory transit time measurements made under simulated overburden pressure.

J. H. J. Ritch, "An Openhole Logging Evaluation in Metamorphic Rocks," Trans., SPWLA Sixteenth Annual Logging Symposium, (1975). Log readings listed are the average values from a range given in the reference. Neutron values for Schlumberger "SNP" (Class $C$ ).

K. Values from well logs:

Company - Reynolds Electric Company and Aerojet Nuclear Company Well

Well

- R.R.G.E. \#2

Field - Raft River Geotherma1

County - Cassia

State - Idaho 
Neutron values from Schlumberger "CNL" (Class B) in Limestone units converted from sandstone log readings. Matrix values computed from Schlumberger "MID" Charts, "Schlumberger Log Interpretation Charts," (1978).

L. Personal Communication, J. L. Dumanoir, (1978) . Neutron values for Schlumberger "SNP" and "CNL" (Classes C and' B).

M. Francis Birch, "Handbook of Physical Constants, "Geological Society of America, Special Paper 36, (1942). Acoustical measurements at STP.

N. Orson L. Anderson and Robert C. Lieberman, "Sound Velocities In Rocks and Minerals," A VESIAC State-ofthe-Art Report, (1966). The average values Iisted are the arithmetic average of samples listed in the reference. Properties at STP.

P. A. F. Woeber, Samuel Katz, and T. J. Ahrens, "Elasticity of Selected Rocks and Minerals," Geophysics, Vol. XXVIII, No. 4, (August 1963), p. 658. Measurements made at STP without porosity correction.

Q. Estimated, assuming nearly complete silicification.

R. M. S. King, "Wave Velocities in Rocks As A Function of Changes in Overburden Pressure and Fluid Saturation," Geophysics, Vol. XXXI, No. 1, (February 1966), pp. 5073. Also reprinted in SPWLA Reprint Volume, "Acoustic Logging," (March 1978).

S. A neutron response in pure sulfur (near zero) may be quite different than the end-point value necessary for resolving the mixture of sulphur and other minerals. For more information, review References $C$ and $T$.

T. Schlumberger Well Services, "Schlumberger Log Interpretation Volume I - Principles," (1972). Neutron values for "GNT" (Class A), apparent Limestone porosity. 
Subtask C: Fracture Delineation

This subtask calls for evaluation of the various techniques for detecting and evaluating the characteristics of fractures from well logs. In the next two quarters, we shall critically evaluate the various fracture-detection techniques.

A single, reliabje interpretation technique for detecting and evaluating fracture systems has not been developed. Many techniques are in daily use with success but may be limited to a particular field or type of formation. Aguilera and VanPoolen (1977) list eight different methods for approaching the problem and 2.14 references. Thirty-two of these references are related to log-analysis techniques.

Of the many log-analysis techniques available, the most difficult problem is determining wihich method to use. Local experience is the best key to success in this situation. Exploratory wells may present an evaluation problem if only limited data are available. The following are brief discussions of several techniques or log characteristics which may be used to detect fractures.

The definition of a fracture system involves the location of the fractures (the depth at which the fractures occur), the width of the fracture (the ciperture), and the orientation of the fracture (whether it is horizontal or vertical, the degree of oif, or the azimuth). It is also important to know if the fracture is open or plugged with solids such as precipitates from geothermal water or swelling clay, etc. The easiest and the first indication of fractures in a well as it is being drilled is $a$ sudden increase in the rate of drilling. Also, if drilling mud is used, it is likely that fracture zones will cause significant lost circulation compared to the non-fractured zones in the vell. Thus, the 
drilling record of the well can sometimes be used to delineate the existing fracture systems in the well. Similarly the drill-cutting $\log$, which is a description of the drill cuttings obtained continuously as the viell is drilled, can be useful in identifying fractures. For example, in the Roosevelt Hot Springs field in Utah, the fracture systems are normally associated with the development of quartz crystals ("drusy" quartz) on the fracture surface (Crosby, personal communication, 1976). Thus when drilling a well in this. field, the occurrence of "drusy" quartz in drill cuttings is an indication that the drill bit has reached a fracture system.

Various well logs can indicate the location of fracture zones and can be used to understand the fracture characteristics. For example, the caliper log provides the diameter of the well bore with depth. Whenever there are fractures in the well, it is likely that the diameter of the well bore will be larger at the depth of the fractures. Thus a caliper log can indicate location of fractures. The six-arm caliper log can be used to estimate the dip of the fracture. Temperature logs can indicate fractures by perturbation in the temperature profile in the well bore. For example, if a newly drilled well produces hot water or steam through a fracture system at a certain depth, the temperature at that depth is likely to be higher than that expected from the general temperature gradient in the well which is partially cooled due to mud circulation. On the other hand, during back flow of an injection well, the temperature at the points where injection water enters the formation will be lower than that expected from the general temperature gradient in the well.

There are several commercial. logs which are useful for finding fractures, for example, the so-called Fracture Finder log, Microseismogram log, etc. These logs are based on transmission of sonic waves through the formation. Scnic 
wave amplitude is affected by the presence of fractures. Both shear and compressional wave amplitudes can be measured and be used to analyze the fracture characteristics. A full-wavetrain sonic log can indicate the presence of fractures, such as had been used successfully in the Los Alamos Hot Dry Rock Project. The sonic velocity log can be used to obtain an approximate estimate of the amount of fracture porosity in a formation. For example, in an otherwise dense formation, the presence of isolated fractures will not affect the sonic travel times as presented on the log, whereas other porosity logs such as density and neutron are affected by the presence of fractures. Hence, the difference between the porosity as calculated from a density log and the porosity as obtained from a sonic log gives an approximate value of the amount of the fracture porosity in the formation. Another type of sonic device useful for locating and understanding fracture systems is the borehole televiewer log. This log gives the "picture" of the fracture at the wellbore surface. From this picture, one can obtain the location, width, orientation, and shape of the fracture. Thus a borehole televiewer $\log$ is the most "visible" fracture evaluation method. Until recently, however, the borehole televiewer $10 \mathrm{~g}$ was not available for geothermal wells because of the temperature limitations of the logging tool. Recently, the United States Geological Survey, Keys (1978), developed a borehole televiewer tool that can perform up to very high temperatures on the order of $204^{\circ} \mathrm{C}\left(400^{\circ} \mathrm{F}\right)$ and provide reliable "pictures" of fractures. Borehole televiewer logs using this equipment have been obtained successfully in various geothermal systems, such as the Los Alamos Hot Dry Rock Project, Raft River Geothermal Field in Idaho, the Roosevelt Hot Springs Field in Utah, etc.

Electrical logs of various kinds can be used to obtain information about fracture systems in a well. For example, self-potential logs can show fractures in an otherwise 
massive formation by indicating the presence of streaming potential in a well. Usually, in a massive formation such as those encountered in the Los Alamos wells, the selfpotential log does rot frovide any meaningful data except in fracture zones where self-potential consists frimarily of the streaming potential. In a massive formation, electrical resistivity is practically infinite. However, when there are fractures, the water content in the fracture reduces the formation resistivity. Hence, resistivity logs can indicate the presence of fractures by a sudden lowering of resistivity. The single point resistivity is especially sensitive to rock geometry. A combination of deep and shallow investigation resistivity devices can be used effectively to obtain some idea about orientation of fractures around the wellbore. Another possible approach to determining the presence of fractures from electrical logs is to plot the formation resistivity factor as obtained from the resistivity log versus the porosity of the formation on log/log paper, and then determine the slope of the line that fits the data. The principle here is that if the formation has intergranular porosity, the slope of that line is approximately two. Whereas, if it is a uniformly spaced fracture system, the slope of the line is of the order of one. Thus the slope of the formation resistivity factor vs porosity line could be utilized as a fracture indicator.

The short-spaced detector of dual-spaced compensated density logs may be more influenced by a nearby fracture than the longer spacing. If the borehole is smooth and without a mudcake, fractures may cause a larger correction than would be expected.

Tools commonly used for measuring dip data are successful.Iy used in locating fractures. Being heterogeneous around the borehole, a fracture crossed by one of the microresistivity pads will cause a much lower reading than a pad 
reading unfractured dense rock. In addition, orientation of the fracture can be determined if the fracture is encountered by more than one pad.

Computation of Bulk Modulus from sonic and density logs may locate the more dense, brittle rock more likely to have fractures.

West and Laughlin (1976) related increases in uranium content with fractures from the Spectral Gamma Ray log in the LASL GT-2 well.

It should be noted that for each of the fracturedetection techniques listed, two other possibilities can occur and have been observed.

1. Fractures are indicated but do not exist.

2. Fractures are not indicated but do exist.

These potential discrepancies explain the advantage of experience and knowledge of the formation under evaluation. The exploratory well must be evaluated with all available techniques in order to locate fractures.

The Fenton Hill GT-2 well, discussed in Task 4, was evaluated for fractures using a multi-technique system. Five techniques were used to sum up the term "FRAC".

1. Resistivity

2. Hole washout

3. Excess density correction in gauge hole

4. Comparison of sonic porosity with porosity from neutron and density

5. Mechanical properties (using sonic and density) 
Each individual test which indicated fractures added a value of 1 to FRAC, giving a range of 0 to 5 . The larger the term FRAC, the greater the likelihood for the existence of fractures. An analog playback of this term is included in Figure 4.16 .

\section{REFERENCES}

Aguilera, Roberto and VanPoolen, H. K., "Current Status on The Study of Naturally Fractured Reservoirs," The Log Analyst, (May-June 1977).

Keys, W. Scott, GLIP Steering Committee Meeting, El Paso, Texas, (June 12-13 1978).

West, Francis G., and Laughlin, A. William, "Spectral Gamma Logging in Crystalline Basement Rock," Geology, Volume 4, (October 1976). 
Subtask D: Temperature Transient Analysis

This subtask calls for evaluating the various temperature transient analysis techniques and associated temperature log data. As a first step toward this, we have completed a literature search which revealed that the body of literature on this topic can be broadly grouped into five categories.

Conductive Models - In these approaches, the well bore is considered a cylindrical source (or sink) of conductive heat. No fluid movement radially outward from the well is considered.

Fluid Loss Models for Fractures - These approaches consider the convective heat flow due to loss of fluid curing drilling or injected water in fractures.

Fluid Loss Models for Porous Zones - The same as above category, except that porous formation rather than a fracture is present.

Injection Profile Estimation - These papers deal with the prediction and interpretation of water (or gas) injection profiles from temperature logs.

General Temperature Log Interpretation - There are a large number of papers dealing with various cther aspects of temperature log interpretation.

A list of the collected references under these categories follows. 
REFERENCES - CONDUCTIVE MODELS

Albright, J. N., "Temperature Measurements in the PreCambrian Section of Geothermal Test Hole No. 2, Los Alamos Scientific Laboratory report LA-6022-MS, Los Alamos New Mexico, New Mexico (July 1975).

Albright, J. N., "A new ìnd More Accurate Method for the Direct Measurement of Earth Temperature Gradients in Deep Boreholes," Proceedings Second U.N. Symposium on Development and Use of Geothermal Resources, San Francisco (1975).

Carslaw, H. S. and Jaeger, J. C., "Conduction of Heat In Solids," Oxford U. Press, Amen House, London (1950).

Cooper, L. R. and Jones, C., "The Determination of Virgin Strata Temperatures from Observations in Deep Boreholes," Geophysics, Volume 2 (1959).

Crosby, G. W., "Prediction of Final Temperature," Second Annual Workshop on Geothermal Reservoir Engineering," Stanford University, Calif. (December 1976).

Dowdle, W. I. and Cobb, W. M., 1975. "Static Formation Temperature from Well Logs -- An Empirical Method," Journal of Petroleum Technology (November 1975).

Edwardson, M. J., Girner, H. M., Parkinson, H. R., Williams, C. D., and Mathews, C. S., "Calculation of Formation Temperature Disturbances Caused by Mud Circulation," Journal of Petroleum Technology (April 1962).

Gulati, M. S., "Pressure and Temperature Buildup in Geothermal Wells," First Annual Workshop on Geothermal Reservoir Engineering, Stanford University, Stanford, California (December 1975).

Lachenbruch, A. H. and Brewer, M. C., "Dissipation of the Temperature Effect in Drilling a Well in Arctic Alaska," USGS Bulletin 1083-C (1959).

Messer, P. H., "Estimation of Static Reservoir Temperature During Drilling Operations," Second Annual Workshop on Geothermal Reservoir Engineering," Stanford University, California (December 1976).

Ramey, H. J., Jr., "Wellbore Heat Transmission," Journal of Petroleum Technology (Apri1 1962).

Schoeppel, R. J. and Gilarranz, S., "Use of Well Log Temperatures to Evaluate Regional Geothermal Gradients," Journal of Petroleum Technology (June 1966).

Timko, D. J. and Fertl, W. H., "How Downhole Temperatures, Pressures Affect Drilling," World Oil (October 1972). 
Urban, T. C., Diment, W. H., and Nathenson, M., "East Mesa Geothermal Anomaly, Imperial County, California; Significance of Temperatures in a Deep Drill Hole Near Thermal Equilibrium," Geothermal Resources Council, Transactions, Volume 2, pp. 667-670, July 1978 .

\section{REFERENCES - FLUID LOSS MODELS FOR FRACTURES}

Bodvarsson, G., 1969. "On the Temperature of Water Flowing Through-Fractures," Journal of Geophysical Research, Volume 14, p. 1987 (1969).

Gringarten, A. C., Witherspoon, P. A., and Ohnishi, Y., "Theory of Heat Extraction from Fractured Hot Dry Rock," Journal of Geophysical Research, Volume 80, No. 8, p. 1120 (March 10, 1975).

Lowell, R. P., Chen, C. H., and Fulford, J. R., "On Transient Temperature Inversions in Geothermal Boreholes," Geothermal Resources Council, Transactions, Volume 2 (July 1978).

Wunder, R. and Murphy, H., "Thermal Drawdown and Recovery of Singly and Multiply Fractured Hot Dry Rock Reservoirs," Los Alamos Scientific Laboratory report LA-7219-MS, Los Alamos, New Mexico (April 1978).

\section{REFERENCES - FLUID LOSS MODEL FOR POROUS ZONES}

Kunze, J. F., Stoker, R. C., and Goldman, D., "Heat Transfer in Formation as a Geothermal Reservoir Engineering Tool," presented at the AIChE-ASMF Heat Transfer conference, salt Lake City, Utah (August 15-17 1977).

Lauwerier, H. A., "The Transport of Heat in an Oil Layer Caused by the Injection of Hot Fluid," Appli. Sci. Res., Sec. A, 5, p. 145 (1955).

Marx, J. W. and Langenheim, R. L., "Reservoir Heating by Hot Fluid Injection," Transactions AIME, 216, p. 312 (1959).

\section{REFERENCES - INJECTION PROFILE ESTIMATION}

Bird, J. M., "Interpretation of Temperature Logs in Water and Gas Injection Wiells and Gás Producing Wells," Drilling and Production Practices, API, Drilling and Production Practices, API, 187 (1956).

Moss, J. T. and White, P. D., "How to Calculate Temperature Profiles in a Water-Injection Well," Oil and Gas Journal, 57, No. 11, p. 176 (March 9, 1959.).

Murphy, H. D., "Fluid Injection Profiles - A Modern Analysis of Wellbore Temperature Surveys," Paper No. SPE6783, 52nd Annual Fall Meeting, SPE of AIME, Denver, Colorado (October 9-12, 1977). 
Nowak, T. J., "The Estimation of Water Injection Profiles from Temperature Surveys," Transactions, AIME, 198, p. 203 (1953).

Smith, R. C. and Steffensen, R. J., "Improved Interpretation Guidelines for Temperature Profiles in Water Injection

Wells," Paper No. SPE 4649, 48th Annual Fall Meeting of SPE of A.IME, Las Vegas, Nevada (September 30-October 3, 1973).

Squirer, D. P., Smith, D. D., and Dougherty, E. L., "Calculated Temperature Behavior of Hot-Water Injection Wells," Journal of Petroleum Technology, p. 436 (April 1962).

Witterholt, E. J. and Tixier, M. P., "Temperature Logging in Injection Wells," Paper No. SPE4022, 47th Annual Fall Meeting of SPE of AIME, San Antonio, Texas (October 8-11 1972).

\section{REFERENCES - GENERAL TEMPERATURE LOG INTERPRETATION}

Curtis, M. R. and Witterholt, E. J., "Use of the Temperature Log for Determining Flow Rates in Producing Wells," Paper No. SPE 4637 , 48th Annual Fall Meeting of SPE of AIME, Las Vegas, Nevada (September 30-October 3 1973).

Keller, H. H., Couch, E. J., and Baldwin, W. F., "Quantitative Interpretation of Temperature Logs," Paper No. SPE5091, 49 th Annual Fall Meeting of SPE of AIME, Houston, Texas (October 6-9 1974).

Steffensen, R. J. and Smith, R. C., "The Importance of Joule-Thomson Heating (or Cooling) in Temperature Log Interpretation," Paper No. SPE4636, 48th Annual Fall Meeting of SPE of AIME, Las Vegas, Nevada, (September 30-October 3 1973). 
The interpretation of geothermal well logs is made more difficult for two primary reasons. First, securing sufficient quality data may be difficult because of several factors. Temperature limitations of downhole equipment may prevent the recording of essential surveys. Incomplete logging suites may be run by choice or due to borehole conditions. Well logs may be run but often produce poor quality data due to the borehole environments. Economics may preclude the running of well logs, coring, cuttings examination or other techniques used to gather data. These situations, and others, hinder the development of intexpretation techniques in areas where present methods produce usable answers.

Second, the interpretation techniques commonly used in the petroleum industry are not, in many cases, sufficient to identify or define the desired formation characteristics. The classification of geothermal reservoirs (Task 2) defines four physical properties (plus geologic province) which may vary and require different interpretive approaches. These are fluid phase and temperature, lithology, pore geometry, and fluid chemistry.

The survey of the State of The Art (Task 1) and the example computations shown in Task 4 - Problem definition, demonstrate the need for interpretation development in the following areas.

1. Determination of porosity and lithology in complex formations (igneous, metamorphic and volcanics) is needed for both geologic and reservoir evaluation. For the most part, the computation of porosity is not possible without knowledge of the formation lithology. The evaluation of lithology is currently hampered by lack of special rock-tool 
calibrations (of the matrix response to currently used calibrations) and the interpretation techniques used with the available logs. Inroads into these problems have been made (see Task 5b-Matrix response) and further studies are being made into computer processing and cross plot techniques.

2. Pore geometry interpretation models and the detection and evaluation of fractures are two related problems which still plague the petroleum industry and appears. to be even more important to the geothermal industry. Relationships such as the Formation Resistivity Factor are greatly influenced by pore geometry and fractures and will require further study for reliable definition. Task 5c covers the many techniques currently used for fracture detection and the problems associated with their use. Studies should show which techniques or combinations of techniques will provide the most reliable answers for particular geological areas or rock types.

3. Thermal evaluation of geothermal reservoirs may be improved immediately with better record keeping during logging operations. Bottom hole temperature measurements on each logging operation along with accurate time data between operations and bore hole fluid circulations are valuable for estimating true formation temperature. Various types of temperature interpretation techniques have been surveyed (Task 5d) and models are being developed for testing with available temperature logs. In conjunction with temperature evaluation studies, the detection of thermal alteration from matrix characteristics is being researched on several East Mesa wells. 
Note: M-N PLOT is a trademark of Schlumberger.

The values $M$ and $N$ were developed to facilitate the study of lithology from the sonic, neutron, and density logs. The equations for $M$ and $N$ are shown in Figure $A-1$ on the crossplots relating to their application. Plots $A$ and $B$ are basic porosity crossplots identical in units to the actual computer crossplots shown in Figures 4.1 and 4.3 . However, Plots A and B are extended to include the $100 \%$ water or fluid point.

The primary characteristic of $M$ and $N$ is that all pairs of points which fall on a linear lithology line, regardless of porosity, will have the same value of $M$ or $N$. For example, limestone will have the values $M=0.817$ and $N=0.585$ regardless of porosity value. Other lithologies, having a different matrix point, will resolve their own characteristic values of $M$ and $N$.

The resulting two-dimensional crossplot (see Figure 4.4) combines data from three logs and reflects primarily the lithology with little influence of formation porosity. 


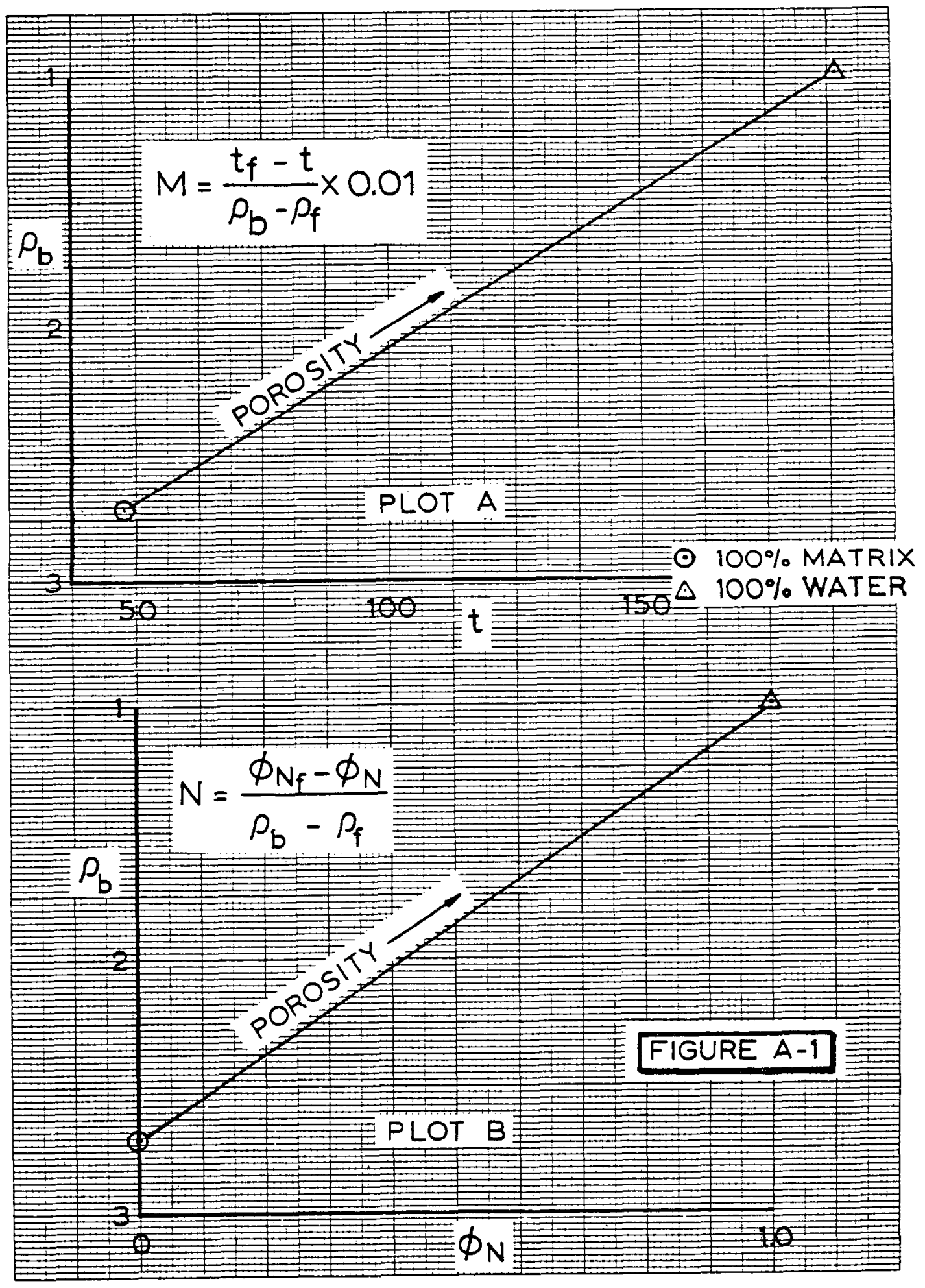




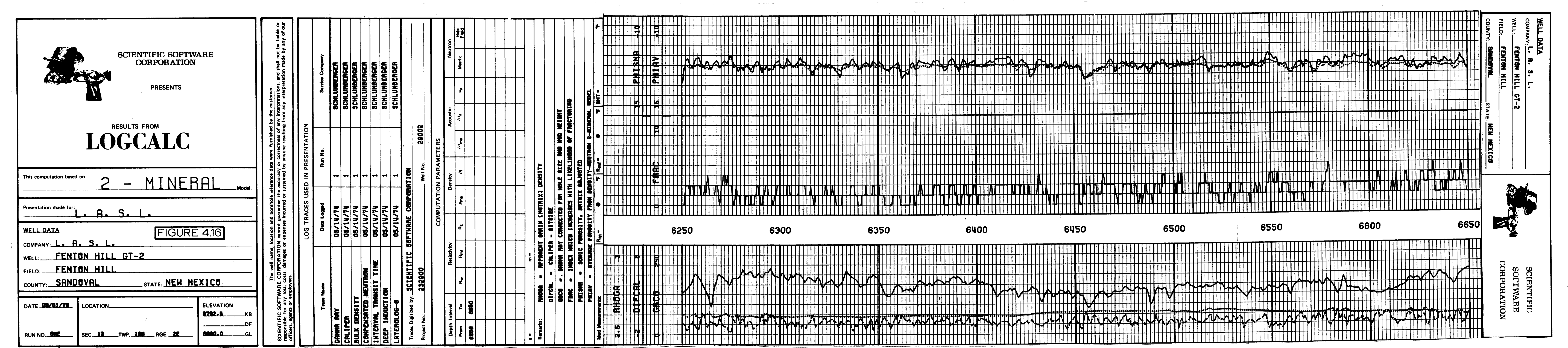




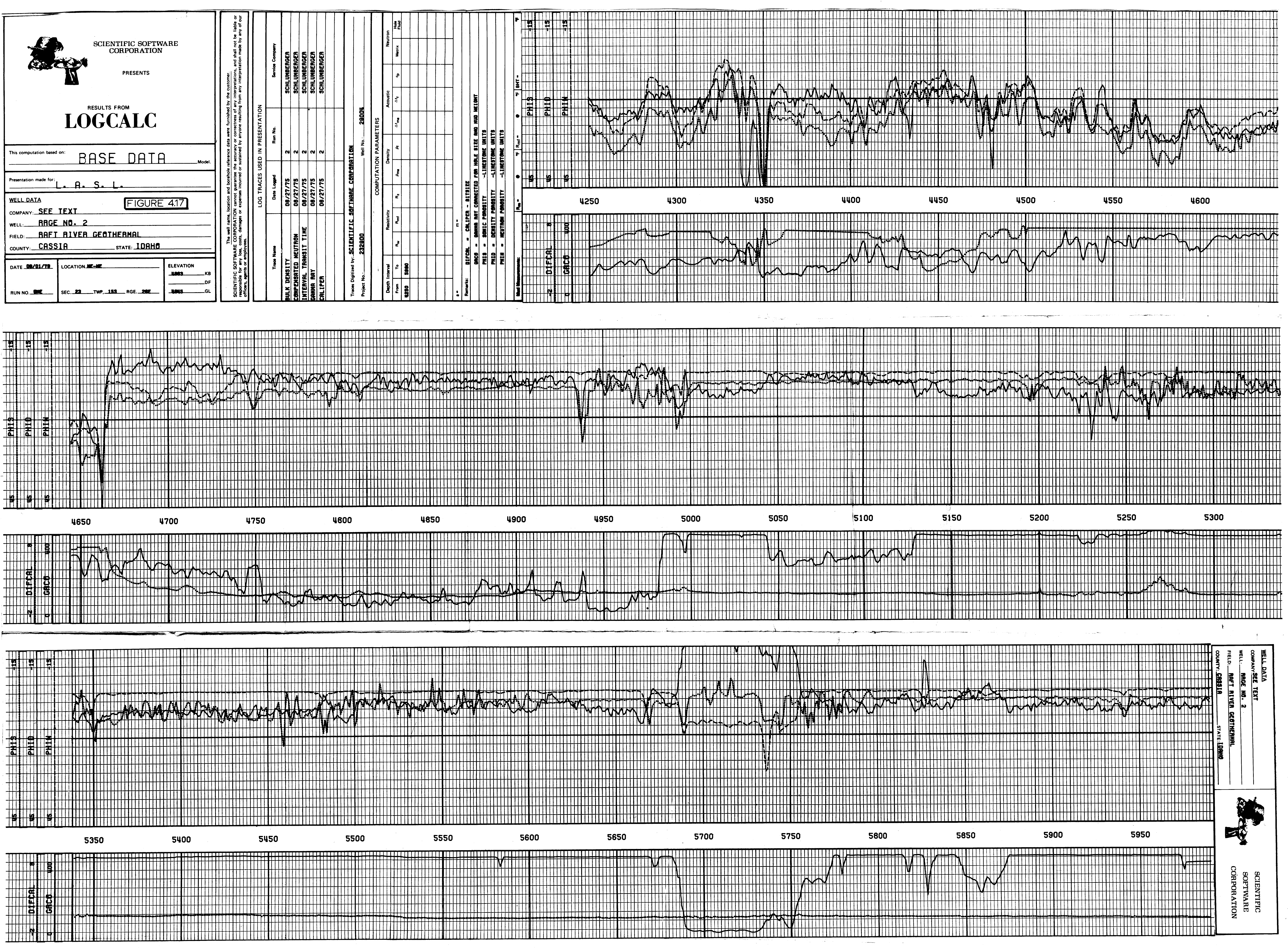



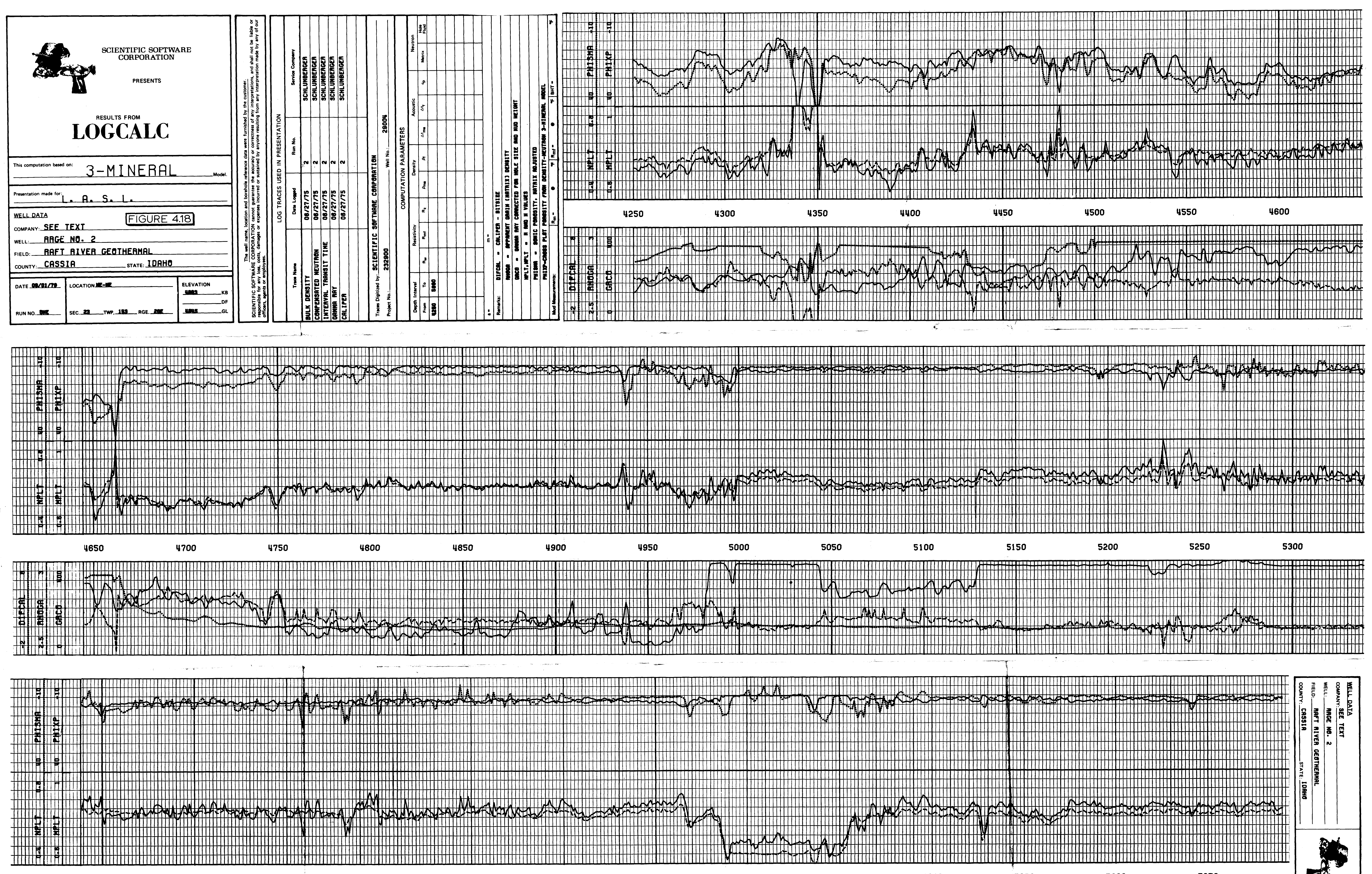

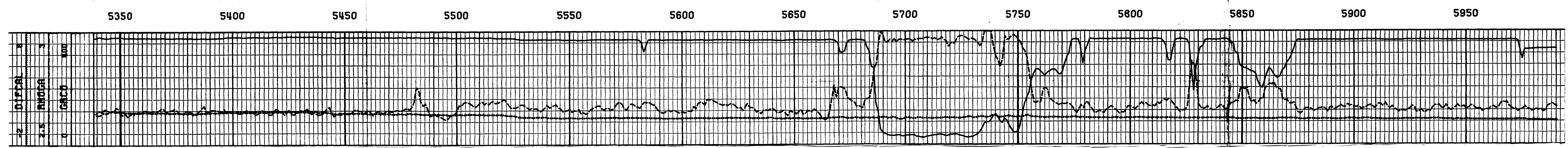

